\author{
Universidade de Brasília \\ Centro de Estudos Avançados Multidisciplinares \\ Programa de Pós-Graduação em Direitos Humanos e Cidadania \\ Mestrado em Direitos Humanos e Cidadania
}

\title{
O DESAFIO DA EDUCAÇÃO INCLUSIVA PARA CRIANÇAS COM DEFICIÊNCIA \\ INTELECTUAL - Um estudo do caso da Escola Estadual Marta da Conceição em Belém-Pará-Amazônia
}

Mestrando: Waldir Macieira da Costa Filho

Orientador: Prof. Dr. Menelick de Carvalho Netto

Linha de Pesquisa 3. História, direitos humanos, políticas públicas e cidadania

\section{Brasília-DF}


Waldir Macieira da Costa Filho

\section{O DESAFIO DA EDUCAÇÃO INCLUSIVA PARA CRIANÇAS COM DEFICIÊNCIA \\ INTELECTUAL - Um estudo do caso da Escola Estadual Marta da Conceição}

em Belém-Pará-Amazônia

Dissertação apresentada ao Programa de Pós-Graduação em Direitos Humanos e Cidadania do Centro de Estudos Avançados Multidisciplinares da Universidade de Brasília como requisito obrigatório para a conclusão do Mestrado. Orientador: Prof. Dr. Menelick de Carvalho Netto

Linha de Pesquisa 3. História, direitos humanos, políticas públicas e cidadania.

\section{Brasília-DF}


Dados Internacionais de Catalogação-na-Publicação (CIP) -

Costa Filho, Waldir Macieira da.

O Desafio da educação inclusiva para crianças com Deficiência Intelectual - Um estudo do caso da Escola Estadual Marta da Conceição em Belém-Pará-A mazônia / Waldir Macieira da Costa Filho. - 2016

113 f.: il.; $30 \mathrm{~cm}$.

Orientador: Menelick de Carvalho Netto

Dissertação (mestrado) - Universidade de Brasília, Centro de Estudos Avançados Multidisciplinares Programa de Pós-Graduação em Direitos Humanos e Cidadania, Mestrado em Direitos Humanos e Cidadania, BrasíliaDF, 2016.

1. Deficientes -- Estatuto legal, leis, etc. -- Brasil. 2. Deficientes -Estatuto legal, leis, etc. -- Brasil. I. Carvalho Netto, Menelick de, orient. II. Título.

CDD: 22. ed. 342.1161

Bibliotecária Elisangela Silva da Costa, CRB-2, n. 983 
Universidade de Brasilia

Centro de Estudos Avançados Multidisciplinares

Programa de Pós-Graduação em Direitos Humanos e Cidadania

Mestrado em Direitos Humanos e Cidadania

Waldir Macieira da Costa Filho

\title{
O DESAFIO DA EDUCAÇÃO INCLUSIVA PARA CRIANÇAS COM DEFICIÊNCIA \\ INTELECTUAL - Um estudo do caso da Escola Estadual Marta da Conceição \\ em Belém-Pará-Amazônia
}

\begin{abstract}
Dissertação apresentada ao Programa de Pós-Graduação em Direitos Humanos e Cidadania do Centro de Estudos Avançados Multidisciplinares da Universidade de Brasília como requisito obrigatório para a conclusão do Mestrado. Linha de Pesquisa 3. História, direitos humanos, políticas públicas e cidadania.
\end{abstract}

Julgado em:

Conceito:

\section{BANCA EXAMINADORA}

Prof. Dr. Menelick de Carvalho Netto

Orientador - Professor PPGDH/UNB

Prof(a). Dr(a). Vanessa Maria de Castro

Examinadora interna PPGDH/UNB

Prof. Dr. Lauro Luiz Gomes Ribeiro

Examinador externo 
À Deus e a todas forças positivas do universo.

A meus pais,

A minha amada Lilia, aos meus filhos Walena, Waldir Neto, e Marina, à minha enteada Carol, e à minha neta Naima.

As pessoas com deficiência.

A todos que lutam por um mundo justo, solidário e ecologicamente sustentável. 


\section{AGRADECIMENTOS}

A minha querida esposa Lilia por ter cuidado da familia e das responsabilidades e afazeres em Belém sem minha ajuda, para que eu pudesse me dedicar exclusivamente a este trabalho.

Ao meu prezado orientador Prof. Menelick de Carvalho Netto e à minha estimada coorientadora Prof. Elizabeth Tunes, pelos ensinamentos, orientação e apoio constante no trabalho de pesquisa e de elaboração desta dissertação.

Aos Professores do Mestrado em Direitos Humanos e Cidadania da UnB, especialmente os professores Vanessa Castro, Nair Bicalho, José Geraldo Junior, Rebecca Abers, Cléria Botelho (in memorian) e Wellington Almeida, pelo aprendizado e orientações.

A amiga e colega de mestrado Vanessa Carneiro, pelas horas juntos pesquisando na biblioteca da UNB e por ter contribuído com suas experiências e conhecimento para minha pesquisa.

As colegas de mestrado Nélia, Ana e Olga por ter compartilhado conhecimentos e dado sugestões para o aperfeiçoamento de minha pesquisa.

Ao Ministério Público do Estado do Pará, através de seus representantes, que proporcionaram, logística e administrativamente, a oportunidade para realização deste trabalho.

A Universidade de Brasilia, que me oportunizou, com sua estrutura, excelente possibilidade para meu estudo e pesquisa.

Aos alunos, professores, direção, demais servidores e pais de alunos da Escola Estadual Marta da Conceição em Belém do Pará, na ilha de Cotijuba, por compartilhar informações e experiências para esse trabalho. 


\section{RESUMO}

O presente estudo tem como objeto a avaliação do processo de implementação da política de inclusão educacional de crianças com deficiência intelectual de 6 a 9 anos matriculadas no ensino fundamental da Escola Pública Estadual Prof. ${ }^{a}$ Marta da Conceição, em Belém do Pará, dentro de uma realidade amazônica e ribeirinha. Em meio a um histórico legislativo, principalmente o advento da Constituição Federal de 1988 e a Convenção sobre os Direitos das Pessoas com Deficiência, está a efetividade de uma política pública pelo Estado brasileiro, e a prática apresentada pelos profissionais da área da educação que necessitaram adaptar o seu modo de ensinar, visando instituir o processo de desenvolvimento cognitivo de todos os alunos e as alunas com deficiência. Verifica-se que ainda competem no dia a dia educacional de atendimento especial dois modos de inserir estudantes com deficiência na escola: a integração e a inclusão, concluindo que o segundo é a melhor forma de fazer a inserção de estudantes não só dentro da escola, mas na sociedade como um todo. O trabalho toma por base o liberalismo igualitário de Ronald Dworkin, a prática pedagógica libertária e autônoma defendida por Paulo Freire, Maria Tereza Mantoan e Ivanilde Apoluceno, a análise de Lev Vygotski, e acima de tudo, no respeito aos direitos humanos e à diversidade humana. O trabalho clama por uma educação que garanta a crianças com deficiência intelectual uma política inclusiva, baseada normativa e primordialmente nos princípios e regras da Convenção sobre os Direitos das Pessoas com Deficiência, onde se reconheça os impedimentos e particularidades das crianças com deficiência intelectual, a partir de uma concepção complexa de igualdade.

Palavras-chaves: educação inclusiva, direitos humanos, política pública, igualdade, crianças com deficiência. 


\begin{abstract}
The object of the present study is the evaluation of the implementation process of the educational inclusion policy for children with intellectual disabilities, aged 6 to 9, enrolled in the state school Prof. ${ }^{a}$ Marta da Conceição, in Belem, State of Para, Brazil, focused on the reality of Amazonian riparian people. Amid a legislative process - chiefly led by the advent of the 1988 Constitution and the UN Convention on the Rights of Persons with Disabilities there is a effectiveness of public policy and the praxis of educators who need to adapt their teaching in order to create a process of cognitive development for all students. It is verified that there are still two main ways to involve students with disabilities in the educational system: through integration and through inclusion. I conclude that the latter is the best way to promote the inclusion of students with disabilities not only in schools, but also in society as a whole. The study is based on Ronald Dworkin's liberal egalitarianism, the autonomous pedagogical practices put forward by Paulo Freire, Maria Tereza Mantoan e Ivanilde Apoluceno, the analysis of Lev Vygotski, and, above all, based on the respect to human rights and to human diversity. The study advocates for a type of education which guarantees an inclusive policy to children with intellectual disabilities, based on the legal principles of the UN Convention, in which the impediments as well as the particularities of children with intellectual disabilities are taken into account, from a complex conceptualisation of equality.
\end{abstract}

Keywords: inclusive education, human rights, public policy, equality, children with intelectual disabilities. 


\section{LISTA DE ILUSTRAÇÕES}

Gráfico 1 - Evolução das matrículas na modalidade da educação especial segundo o Censo Escolar de 2006

Gráfico 2 - Matrículas nas esferas públicas e privadas segundo o Censo Escolar de 2006 38

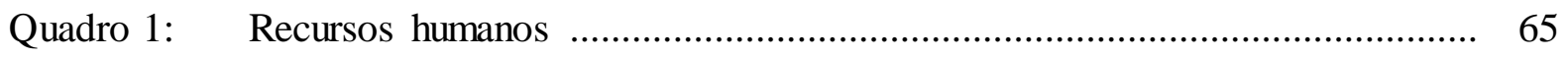

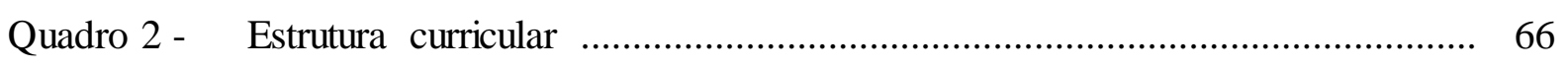

Quadro 3 - Relação dos alunos com DI ............................................................. 70 


\section{SUMÁRIO}

1 INTRODUÇÃO

2 CONTEXTUALIZAÇÃO HISTÓRICA E LEGAL DA EDUCAÇÃO DAS PESSOAS COM DEFICIÊNCIA INTELECTUAL NO BRASIL ....

2.1 Da política de integração das pessoas com deficiência no Brasil ................. 18

2.2 Da transição da política de integração pela segregação para a da 22 inclusão no atendimento ao aluno com deficiência intelectual

2.3 Documentos norteadores da política educacional inclusiva

2.3.1 Declaração de Salamanca

2.3.2 A Convenção sobre os direitos da pessoa com deficiência e a política nacional de educação especial na perspectiva da educação inclusiva

2.3.3 Plano Nacional de Educação (PNE)

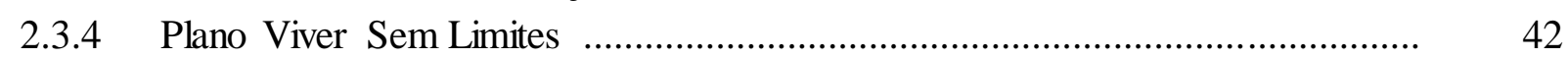

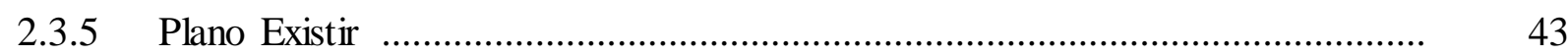

2.3.6 Resolução Estadual $n^{\circ} 001$ de 05 de Janeiro de 2010 do Conselho Estadual 44 de Educação do Pará

2.3.7 O Plano Estadual de Educação no Pará que norteia a política pública da educação especial e inclusiva nas escolas públicas paraenses

2.3.8. Estatuto da Pessoa com Deficiência - Lei 13.145/2016 ................................. 51

2.4 Tendências da educação especial: integração $x \quad$ inclusão 54

2.5 Educação Básica: o ensino fundamental regular público e o aluno com deficiência

3 A ESCOLA ESTADUAL MARTA DA CONCEIÇÃO SITUADA NA ILHA DE COTIJUBA, EM BELÉM NO ESTADO DO PARÁ, E O ENSINO INCLUSIVO DE CRIANÇAS COM DEFICIENCIA INTELECTUAL

3.1 A Ação judicial proposta pelo Ministério Público em prol dos alunos da Escola Marta Da Conceição

4.1 Igualdade, Desigualdade, Exclusão e Inclusão: uma pequena análise a partir dos dados coletados

4.2 A Inclusão Educacional de Crianças com Deficiência Intelectual na escola comum é Possível 


\section{INTRODUÇÃO}

A História é farta em relatos de discriminação às pessoas com deficiência. Porém, foi na primeira metade do século passado, sob a influência da eugenia tida então como saber científico, que a discriminação a esse grupo social chegou ao extremo através de políticas segregacionistas e até mesmo de extermínio colocadas em prática por governos totalitários, como ocorreu no regime nazista alemão ${ }^{1}$.

Com o advento da Declaração dos Direitos Universais da Pessoa Humana em 1948, busca-se consagrar direitos humanos fundamentados no reconhecimento da indivisibilidade e universalidade dos direitos à igualdade, à liberdade e à dignidade do ser humano, independente de sexo, cor, raça, religião e deficiência, passando a ser princípios fundamentais a serem respeitados pelas Nações $^{2}$. A partir de então, impulsionadas principalmente pelos movimentos sociais organizados, políticas públicas de inclusão social de grupos discriminados começaram a ser discutidas, aprovadas e implementadas em boa parte das nações, incluindo o combate à discriminação e exclusão social das pessoas com deficiência.

No Brasil, os primeiros serviços regulares de educação especial se deram a partir de $1950 \mathrm{com}$ as Unidades Educacionais do Instituto Pestalozzi, e as iniciativas do Governo Federal no período de 1957 a 1990, destinados ao atendimento de pessoas com deficiência. O grande problema dessa época é que os serviços eram de caráter assistencialista e não permitia a independência da pessoa com deficiência. As crianças e adolescentes permaneciam na sua maioria atreladas ao estabelecimento educacional até a fase adulta, dependentes da instituição e de ações políticas assistenciais do poder público ${ }^{3}$.

Não por menos a Constituição Federal brasileira prescreve em seu art.205 que "a educação, direito de todos e dever do Estado e da família, será promovida e incentivada com a colaboração da sociedade, visando ao pleno desenvolvimento da pessoa, seu preparo para o exercício da cidadania e sua qualificação para o trabalho"4.

A Conferência Mundial sobre Necessidades Educativas Especiais, realizada pela UNESCO em Salamanca, Espanha, em junho de 1994, teve como tema principal "Acesso e

\footnotetext{
1 ALVES, Rubens Valtecides. Deficiente físico: novas dimensões da proteção ao trabalhador. São Paulo: LTR, 1992.

2 COMPARATO, Fábio Konder. A Afirmação histórica dos direitos humanos. 5. ed. São Paulo: Saraiva, 2007.

${ }^{3}$ MAZZOTTA, M. J. S. Educação Especialno Brasil: História e Políticas Públicas. São Paulo: Cortez, 2005.

${ }^{4}$ BRASIL. Constituição (1988). Constituição da República Federativa do Brasil. Promulgada em 5 de outubro de 1988. Brasília, DF: Senado Federal, 1988.
} 
Qualidade na Educação aos Alunos com Necessidades Educativas Especiais". O Brasil, ao participar e assinar a Declaração final da referida conferência, assumiu o compromisso de reformular todo seu sistema educacional a fim de garantir o acesso de pessoas com deficiência e demais com necessidades educacionais especiais à escola comum, devendo incluí-las numa pedagogia centralizada no aluno e capaz de atender suas necessidades peculiares ${ }^{5}$.

O advento da Lei $n^{\circ} 9.394$ em 1996, denominada Lei de Diretrizes e Bases da Educação Nacional (LDBEN), inseriu formalmente em nosso ordenamento jurídico a política de inclusão do aluno com deficiência na rede regular de ensino, a fim de garantir não só a socialização desses alunos com os demais educandos, mas o desenvolvimento do potencial dessas pessoas. Seguindo esta norma o Ministério da Educação (MEC) juntamente com o Conselho Nacional de Educação (CNE) implementou em 2001, através da resolução CNE/CEB n.2/2001 as Diretrizes Nacionais para a educação especial na educação básica, para que os sistemas de ensino matriculassem todos os alunos com necessidades educacionais especiais, buscando assegurar assim as condições necessárias para uma educação de qualidade para todos (art. $2^{\circ}$ da referida resolução). Atualmente o MEC gere a denominada Política da Educação Especial na Perspectiva da Educação Inclusiva no País, com vistas a possibilitar que os alunos com deficiência sejam matriculados nas escolas comuns, porém a efetivação dessa medida na educação básica depende não só do governo federal, mas principalmente de políticas educacionais regionais a serem implantadas e aperfeiçoadas pelos estados e municípios do País ${ }^{6}$.

A Convenção sobre os Direitos das Pessoas com Deficiência, aprovada pela ONU nos termos da Resolução da Assembleia Geral no 61/106 de 13 de dezembro de 2006, e ratificada pelo Brasil através do Decreto Legislativo $\mathrm{n}^{\mathrm{o}} 186$ de 2008, com efeito de emenda constitucional, norma que norteia os direitos humanos fundamentais da pessoa com deficiência, surgiu como resposta da comunidade internacional à longa história de discriminação, exclusão e desumanização das pessoas com deficiência ${ }^{7}$. Em seu art.24, a

\footnotetext{
5 FAVERO, Eugênia Augusta Gonzaga. O direito das pessoas com deficiência de acesso à educação. In: ARAÚJO, Luiz Alberto David (Coord.); PRADO, Adriana Romeiro de Almeida et al. Defesa dos direitos das pessoas portadoras de deficiência. São Paulo: Revista dos Tribunais, 2006. p. 152.

${ }^{6}$ BRASIL. Ministério da Educação. Política Nacional de Educação Especial na Perspectiva da Educação Inclusiva. 2008. Disponível em: http://portal.mec.gov.br/arquivos/pdf/politicaeducespecial.pdf. Acessado em 04.02.2015.

7 PIOVESAN, Flávia. Convenção da ONU sobre os direitos das pessoas com deficiência: Inovações, alcance e impacto. In FERRAZ, Carolina Valença; LEITE, George Salomão; LEITE, Glauber Salomão; LEITE, Glauco Salomão (coords). Manual dos direitos da pessoa com deficiência. São Paulo: Saraiva, 2012, p.33-51.
} 
Convenção determina a necessidade de os estados-parte garantirem a permanência dessas crianças e adolescentes com deficiência na sala de aula comum, a confirmar o novo conceito de Educação Especial no modelo educacional brasileiro, ao entendê-lo como um processo educacional definido em uma proposta pedagógica que assegure recursos e serviços educacionais especiais, organizados para apoiar, complementar e suplementar os serviços educacionais comuns aos alunos com deficiência.

Grandes esperanças recaem, portanto, sobre as determinações normativas acerca de uma política pública inclusiva do aluno com necessidades educacionais especiais. $\mathrm{O}$ fato de $\mathrm{o}$ Estado do Pará legalmente adotá-las, se, por um lado, parece demonstrar o cuidado institucional para com as necessidades educacionais dessas crianças, por outro, também requer uma análise mais profunda e cuidadosa da forma como essa política tem podido encontrar aplicação. Não basta, é claro, a adoção formal de uma política de inclusão, é também necessário implementá-la de forma consistente. A consistência de uma política educacional só pode ser efetivamente alcançada mediante o constante acompanhamento crítico de sua implementação, pois só assim os problemas de percurso podem ser identificados e, com isso, buscar-se tratá-los da forma adequada. Pensando no desafio da realização de uma análise dessa empreitada, ainda que em nível microrregional, no prazo hábil para a conclusão do mestrado, algumas seletividades se impuseram. Primeiro a delimitação do tema a um tipo de deficiência, no caso a deficiência intelectual, devido à necessidade de maiores intervenções pedagógicas para a inclusão educacional desse segmento discente; segundo a escolha de escola na região amazônica devido à carência e dificuldades dos moradores das regiões ribeirinhas da à bacia amazônica para usufruir das políticas públicas e direitos fundamentais; terceiro a necessidade de recorte da pesquisa às primeiras séries do ensino fundamental onde se verificam as primeiras ações de estimulação e habilitação dessas crianças com deficiência, vitais para sua permanência na classe comum e para o seu desenvolvimento educacional e social, já que um dos propósitos principais da política de educação especial na perspectiva da educação inclusiva, acima expostas, é promover o desenvolvimento global da criança (0-14 anos) com deficiência intelectual, sua emancipação e inclusão social.

Cabe aqui esclarecer que o aluno com deficiência intelectual sujeito desse estudo é a pessoa que apresenta um atraso no seu desenvolvimento, dificuldades para aprender e realizar tarefas do dia a dia e interagir com o meio em que vive. Existindo um impedimento cognitivo, que acontece antes dos 18 anos, e que prejudica suas habilidades adaptativas.

Assim, justifica-se a relevância dessa pesquisa que teve como objeto a avaliação do processo de implementação da política de inclusão educacional de crianças com deficiência 
intelectual matriculadas na etapa de alfabetização (6 a 8 anos), no ensino fundamental no município de Belém, Estado do Pará, Amazônia, Brasil, a partir da realidade de uma escola pública estadual que também atende a crianças com deficiência intelectual. Trata-se da Escola Estadual de Ensino Fundamental e Médio (Escola Pública Estadual) Prof. ${ }^{a}$ Marta da Conceição, localizada no Estado do Pará, região amazônica, no município de Belém, distrito de Icoaraci, na ilha de Cotijuba, localizada na Rua Jarbas Passarinho, sem número, CEP: 66810-980, a qual tem as seguintes etapas de Ensino: Ensino Fundamental; Ensino Médio; Educação de Jovens e Adultos (EJA).

Segundo dados do Censo 2012 do Ministério da Educação (MEC), a escola tem na sua infraestrutura: 8 salas de aulas, sala de diretoria, sala de professores; laboratório de informática; sala de recursos multifuncionais para Atendimento Educacional Especializado (AEE); cozinha; banheiro dentro do prédio; e os seguintes equipamentos: TV, DVD, Copiadora, Retroprojetor e Impressora. Além disso consta que tem água filtrada; água da rede pública; energia da rede pública; lixo destinado à coleta periódica e não possui esgoto.

Segundo os dados apurados no site de Guia das Escolas, Creches e centros educativos no Brasil, a partir de índices disponibilizados pelo MEC - INEP - Instituto Nacional de Estudos e Pesquisas Educacionais Anísio Teixeira ${ }^{8}$, a escola tem Atendimento Educacional Especializado (AEE) a alunos com necessidades educacionais especiais, com sala multifuncional equipada, e oferece cursos de Libras (Língua Brasileira de Sinais), cursos da língua escrita para alunos com Deficiências; cursos de comunicação alternativa e aumentativa; cursos de Braille; cursos do uso de recursos ópticos e não ópticos; cursos de uso do soroban; cursos para autonomia na escola; cursos para o desenvolvimento de processos mentais; cursos de capacitação em orientação e mobilidade. Porém, contraditoriamente, consta que a escola não garante acessibilidade, pois a escola e suas dependências não são acessíveis para as pessoas com deficiência.

Uma visita foi feita pelo Ministério Público Estadual do Pará (MP) em fevereiro de 2013 ao referido estabelecimento de ensino público e constatou condições precárias do local onde a escola funciona, com um número de alunos além de sua capacidade e não estando legalmente autorizada e reconhecida pelo Conselho Estadual de Educação do Pará. Em virtude desta visita, o Ministério Público do Pará impetrou ação civil pública ao Juiz de

\footnotetext{
${ }^{8}$ PARÁ. Secretaria de Estado de Educação. Escola Estadual Professora Marta da Conceição em Belém. [2015]. Disponível em: http://guia-para.escolasecreches.com.br/ensino-regular/ESCOLA-ESTADUAL-PROFESSORAMARTA-DA-CONCEICAO-belem-belem-para-i15042952.htm. Acesso em: 26.08.2015.
} 
Direito da $3^{\text {a }}$ Vara da Infầncia e da Juventude de Icoaraci que abrange a ilha de Cotijuba. A referida ação pedia, liminarmente, baseada no Estatuto da Criança e do Adolescente, que o projeto pedagógico da Escola Estadual de Ensino Fundamental e Médio Professora Marta da Conceição, localizada na Ilha de Cotijuba fosse revisto na sua essência, a regularização da escola junto ao conselho estadual de educação, bem como reiterava a cobrança da Secretaria de Educação do Pará em relação à prestação de contas do conselho escolar e à reeleição para o conselho no prazo de 15 dias. Segundo a ata de reunião da Assembleia Geral do Conselho Escolar da Escola Professora Marta da Conceição de outubro de 2009, a escola vinha enfrentando uma série de dificuldades desde 2006 e que foram agravadas no ano seguinte, em 2007, quando a falta de professores e aulas se tornou mais frequente. A situação era a de professores destratados sem a reposição de novos e de falta de segurança na área da escola que possui quatro anexos (Tiradentes, Santo Antônio, Urubuoca e Pedra Branca). Além da falta de quadra esportiva e de lazer, quadra que fora solicitada desde 2006 à SEDUC; banheiros sem acessibilidade; não funcionamento da sala de informática, apesar de estar com todos os equipamentos, e a sala não funcionava por falta de professor lotado. Posteriormente a essas denúncias, o Ministério Público instaurou novo procedimento administrativo disciplinar para investigar a carência estrutural da escola, que prejudicava o direito à educação de todos os adolescentes e crianças matriculados. A escola também não possuía biblioteca e no laboratório havia alguns equipamentos danificados por falta de uso que não funcionavam desde 2009, quando esses equipamentos chegaram, por falta de professor. O Ministério Público requereu ainda a aquisição e a implementação de recursos pedagógicos e tecnológicos em número suficiente para a demanda discente, a construção e a aquisição de acervo para a biblioteca, bem como a capacitação dos docentes. O Estado, pela ação proposta, deveria também realizar uma reforma geral na escola. ${ }^{9}$

No dia 06 de setembro de 2013, o citado Juiz da $3^{\text {a }}$ Vara da Infância e Adolescência de Icoaraci acatou a ação do Ministério Público e determinou no prazo improrrogável até então de 60 dias que o Estado do Pará providenciasse a reforma estrutural.

No início do ano de 2015, na página oficial da Secretaria de Educação do Estado do Pará, a mesma informa:

\footnotetext{
${ }^{9}$ PARÁ. Ministério Público. ICOARACI: MP ajuíza ACP contra o Estado por condições precárias em escola na Ilha de Cotijuba. 12.04.2013. Disponível em: http://www.mppa.mp.br/index.php?action=Menu.interna\&id=2182 $\&$ class $=$ N. Aces so em: 26.07.2015.
} 
O ano letivo de 2015 será marcado pela revitalização da estrutura física das escolas da Região Metropolitana de Belém e interior do Estado. Além das 400 frentes de trabalho elencadas no Pacto pela Educação no Pará, a Secretaria de Estado de Educação (Seduc) já licitou mais de 25 obras, somente nos primeiros 60 dias da atual gestão. As novas obras licitadas foram identificadas a partir de um levantamento conjunto entre a instituição e a comunidade escolar. São reformas, ampliação e construção de escolas em vários municípios paraenses, num montante estimado de mais de R\$ 15 milhões em recursos do Orçamento do Estado. Já estão em fase de execução do processo licitatório as obras de reforma da sede da Escola Estadual de Ensino Fundamental Marta da Conceição e do anexo 'Pedra Branca', na Ilha de Cotijuba.

Interessante que a Secretaria informa sobre as reformas no prédio da escola de Cotijuba, não dando informações sobre a contratação e capacitação de professores, da reavaliação do modelo pedagógico, condições de acessibilidade, materiais pedagógicos e equipamentos na escola.

A escola pesquisada, pelo sistema online da Secretaria Estadual de educação (SEDUC), tem vinte e cinco vagas disponíveis para matrícula de alunos com necessidades educacionais especiais no Atendimento Educacional Especial (AEE). Sendo que 15 vagas são para alunos com deficiência intelectual. Segundo informações estavam matriculados no ano de 2015 dezoito alunos com deficiência intelectual, três a mais do previsto. Sendo que da $1^{\mathrm{a}}$ a $3^{\text {a }}$ séries do ensino fundamental, a serem pesquisadas, teriam aproximadamente de cinco a sete crianças com deficiência intelectual.

A pesquisa buscou, a partir da difícil realidade desta escola pública de ensino fundamental que atende a alunos com deficiência intelectual, mapear, em uma perspectiva interdisciplinar, as possibilidades e as dificuldades encontradas, mediante entrevistas e visitas ao local, verificando o cumprimento ou não das políticas públicas na perspectiva de uma educação inclusiva à luz das determinações do Direito (numa perspectiva principiológica para a realização de direitos fundamentais, como a igualdade e a educação) e da Pedagogia (numa perspectiva emancipatória e inclusiva de grupos excluídos da sociedade), e dos princípios e normas fundamentais da Constituição Federal, leis infraconstitucionais e Convenções e Declarações internacionais de proteção aos direitos humanos da pessoa com deficiência, além de experiências educacionais inclusivas e libertárias que contribuam para a busca de uma igualdade de oportunidade, de soluções viáveis à superação dos obstáculos e discriminações enfrentados pelos referidos alunos com deficiência intelectual.

Pela natureza da própria questão concreta proposta analisamos o grau de efetividade de uma política juridicamente prefigurada por comandos normativos que visariam a assegurar densidade social ao direito à igualdade de alunos com deficiência intelectual, e, portanto, uma metodologia difícil foi requerida. Por um lado, imprescindível a análise reconstrutiva das 
determinações normativamente fixadas na regulamentação da política de atendimento dos cuidados específicos desse aluno com necessidades especiais visando a assegurar-lhe direito à igualdade no plano educacional, precisamente pela via da atenção diferenciada. O que exigiu, portanto, o recurso à metodologia própria da interpretação jurídico-normativa, neste caso uma análise crítico-normativa, tendo como objeto de análise e crítica as teorias hermenêuticas e interpretativas que auxiliam na tarefa de aplicação do Direito. ${ }^{\mathbf{1 0}}$ De outro lado, a verificação em uma escola das práticas institucionais efetivamente levadas a efeito no que se refere à atenção (ou à falta dela) voltada a atender suas especificidades. O levantamento dos dados empíricos e as entrevistas com os atores envolvidos no processo educacional dessas crianças, bem como o diálogo feito com seus seus pais requereu metodologia específica própria das demais ciências sociais, neste caso, o de uma pesquisa qualitativa crítica ${ }^{\mathbf{1 1}}$

Assim foi que, considerando-se a natureza do problema proposto, necessariamente a metodologia utilizou-se primeiramente de uma pesquisa jurídico-normativa, a partir de um estudo da perspectiva normativa-emancipatória de um segmento discriminado, realizando primeiramente, um levantamento bibliográfico e uma análise jurídica das normas internacionais e nacionais, da doutrina jurídica, e da literatura na área dos direitos humanos e da educação, voltadas às pessoas com deficiência e sua inclusão educacional, além do levantamento de dados que envolvem alunos com deficiência intelectual na fase de alfabetização junto a Secretaria de Estado de Educação do Pará e Ministério da Educação. Realizou-se pesquisa também junto ao Ministério Público e o Poder Judiciário local sobre os feitos abrangendo a escola pesquisada.

Após, foram feitos a coleta e fichamento do material teórico e estatístico, com o objetivo de criar os referenciais de análise e identificar os melhores indicadores para verificação dos dados levantados, por meio de entrevistas dos atores envolvidos na escola pesquisada, a segunda etapa, com a finalidade de construir o enfoque descritivo qualitativo da escola escolhida no município de Belém, Distrito de Icoaraci, ilha de Cotijuba. Assim, valendo-nos de entrevistas com o corpo docente e diretivo, envolvendo também outros profissionais da escola pesquisada, verificamos suas práticas profissionais e dificuldades no

\footnotetext{
10 “[...] trata-se de uma concepção epistemológica da dogmática jurídica (que pode ser denominada inclusiva), a qual leva em conta uma multiplicidade de perspectivas quando da elaboração de respostas aos problemas de pesquisa colocados". In GUERRA FILHO, Willis S. Processo constitucional e direitos fundamentais. São Paulo : Celso Bastos Ed., 1999, p. 34.

11 "A pesquisa qualitativa pode ser caracterizada como a tentativa de uma compreensão detalhada dos significados e características situacionais apresentadas pelos entrevistados". In: RICHARDSON, Roberto Jarry. Pesquisa Social: métodos e técnicas. São Paulo: Atlas, 1999, p. 91.
} 
atendimento dos alunos com necessidades educacionais especiais na área intelectual. Foram também realizadas entrevistas com familiares de dois alunos com deficiência intelectual matriculados na escola.

Após essa etapa, foram organizados os dados e conferidos os resultados. Ao final, realizou-se a revisão dos resultados e a redação final do texto.

Importante registrar que a escolha do tema e do lugar da pesquisa foi influenciada também pela atuação deste autor como Promotor de Justiça titular da Promotoria de Defesa dos Direitos das Pessoas com Deficiência e Idosos do município de Belém-Pará, junto ao Ministério Público do Estado do Pará, onde atende várias demandas que envolvem os direitos deste segmento das pessoas com impedimentos intelectuais, inclusive alunos infantes e seus familiares na busca pela inclusão educacional nas escolas comuns públicas e privadas. Sendo que esta atuação específica já ocorre desde abril de 1996.

Outro registro importante é o fato deste autor atuar junto ao Conselho Nacional dos Direitos das Pessoas com Deficiência - CONADE, em Brasilia-DF, desde 2002, como membro eleito pela Associação Nacional dos Membros do Ministério Público de Defesa das Pessoas Idosas e com Deficiência - AMPID, onde mantém constante diálogo com a sociedade civil organizada e o movimento nacional das pessoas com deficiência, que integram este conselho paritário com representantes do Governo Federal, onde discutem e deliberam por políticas públicas mais efetivas que garantam autonomia e dignidade a esse segmento ainda discriminado na sociedade brasileira. 


\section{CONTEXTUALIZAÇÃo HISTÓRICA E LEGAL DA EDUCAÇÃO DAS PESSOAS COM DEFICIÊNCIA INTELECTUAL NO BRASIL}

\subsection{Da política de integração das pessoas com deficiência no Brasil}

Antes de adentrarmos no sujeito especifico da pesquisa, o aluno com deficiência intelectual, é necessário relatarmos inicialmente como se iniciou a educação das pessoas com deficiência em geral no Brasil.

Essa educação especializada em pessoas com deficiência se inicia historicamente no Brasil com a criação de duas instituições, que funcionavam como internatos e se baseavam nas ideias iluministas, apresentando como objetivo formal em seus estatutos inserir os seus alunos na sociedade brasileira. Segundo relata Marcos Mazzotta 12 a primeira foi criada em 12 de setembro de 1854 através do Decreto Imperial $n^{\circ} 1.428$ e inaugurada no dia 17 do mesmo mês pelo imperador Dom Pedro II. Fica localizada no bairro da Urca, na cidade e estado do Rio de Janeiro e recebeu o nome de Imperial Instituto dos Meninos Cegos, sendo atualmente conhecida como Instituto Benjamin Constant (IBC). Esta se tornou uma tradicional instituição de ensino para deficientes visuais e é considerada como o primeiro passo concreto no país para garantir ao aluno com deficiência o direito à escolarização.

Dois anos mais tarde, começa a funcionar em $1^{\circ}$ de janeiro de 1856 o Colégio Nacional para Surdos-Mudos, criado por iniciativa do surdo francês Eduard Huet que havia apresentado a Dom Pedro II, em junho de 1855, um relatório descrevendo a sua intenção de criar uma escola para surdos no Brasil, tendo ele já sido diretor de uma instituição para surdos na França. Lanna Júnior 13 descreve que,

\footnotetext{
O currículo consistia no ensino elementar incorporado de algumas matérias do secundário. $\mathrm{O}$ ensino profissionalizante focava-se em técnicas agrícolas, já que a maioria dos alunos era proveniente de famílias pobres do meio rural. Em meados da década de 1870, foram instaladas oficinas profissionalizantes de encadernação e sapataria.
}

Até o ano de 1908, era considerada a data de fundação do Instituto o dia $1^{\circ}$ de Janeiro de 1856, porém ocorreu uma mudança fundamentada no artigo $7^{\circ}$ do decreto $n^{\circ} .6 .892$ de 19

\footnotetext{
12 MAZZOTTA, 2005, op cit., p. 28.

13 LANNA JUNIOR, Mário Cleber Martins. História do Movimento Político das Pessoas com Deficiência. Brasília: DF: Secretaria Nacional de Promoção dos Direitos das Pessoas com Deficiência, 2010. p.21-22.
} 
de março de 1908, que transferiu a data de fundação para a da promulgação da Lei 939 de 26 de setembro de 1857 que em seu artigo 16, inciso 10, fazia constar que o Império passava a subvencionar o Instituto. Antes desse decreto os alunos eram subvencionados por entidades particulares ou públicas e até mesmo pelo Imperador. Cabe relembrarmos que a "Constituição Política do Império do Brazil", de 1824, expressava a gratuidade da instrução primária a "todos os cidadãos", porém lembremos que nesta época os escravos (na sua maioria negros) não eram considerados cidadãos e as mulheres tinham uma minus valia em relação aos homens na época, o que reduzia o conceito de "todos", além disso, não definia, nem nas leis infraconstitucionais, de quem era a responsabilidade dessa educação, se do estado ou da iniciativa privada, e desse modo não se garantiu na prática o acesso de toda a população a essa educação, muito menos a pessoas com deficiência.

Para Monica Kassar ${ }^{\mathbf{1 4}}$ essa ausência de garantia de educação fica clara em face da escassa presença do estado nessa área e do oferecimento de ensino pelas instituições privadas, principalmente religiosas. Havia algumas províncias, que por não ter condições de oferecer educação às crianças da zona rural ou de periferias distantes dos centros onde havia escolas, e ainda menos às crianças com deficiência, as dispensavam da frequência às aulas, e consequentemente do acesso à educação.

Até o final do século XIX, o Estado brasileiro não promoveu novas ações relevantes para as pessoas com deficiência e apenas expandiu, de forma modesta e lenta, os institutos de cegos e surdos para outras cidades. As poucas iniciativas, além de não terem a necessária distribuição espacial pelo território nacional e atenderem uma minoria, restringiam-se apenas aos cegos e surdos, deixando as crianças com deficiência intelectual excluídas.

Com o advento da República, há uma difusão grande no Brasil do pensamento evolucionista, que deixa influências evidentes na sociedade, principalmente na educação. Monica Kassar, comenta que neste período, procura-se buscar através da educação um método racional para o estudo e desenvolvimento das faculdades mentais do indivíduo ${ }^{15}$. A exaltação, segundo a mesma autora, do movimento autônomo da natureza é também expressa pelo pensamento positivista que deixa suas contribuições na construção das bases epistemológicas da educação especial para o atendimento a alunos com deficiência intelectual.

\footnotetext{
${ }^{14}$ KASSAR, Monica de Carvalho Magalhães. Deficiência Múltipla e Educação no Brasil. São Paulo: Autores Associados, 1999.

15 Id., Ibib.
} 
O processo de industrialização e urbanização do Brasil que se iniciou, ainda timidamente, a partir de 1920 (aprofundando-se nas décadas de 40 e 50), ocasionou o surgimento, ainda escasso, de iniciativas da sociedade que implementaram entidades que tratavam de outras especificidades além da cegueira e da surdez, fazendo um acompanhamento mais abrangente, pois cuidava também da saúde além da educação. Nesse período começa os primeiros serviços do movimento pestalozziano que se voltavam para as deficiências intelectuais, além da criação dos centros de reabilitação que atendiam às pessoas que haviam sido atingidas pelo surto de poliomielite nesse período.

O Instituto Pestalozzi foi criado em 1926, baseado nos ideários do pedagogo suíço Johann Heinrich Pestalozzi (1746-1827), na cidade de Canoas no Rio Grande do Sul. Ganhou maior notoriedade a partir do trabalho da pedagoga russa Helena Antipoff que veio ao Brasil para trabalhar em Belo Horizonte. Sua atuação foi fundamental para maiores debates acerca da temática que envolvia as pessoas com deficiência intelectual no Brasil. Ela criou em 1932, o Instituto Pestalozzi de Belo Horizonte. Em seguida, diversas cidades criaram o seu Instituto pestalozziano e atualmente somam-se cerca de 150 sociedades Pestalozzi associadas à Federação Nacional das Sociedades Pestalozzi (FENASP).

O advento da Declaração dos Direitos Universais da Pessoa Humana, em 1948, após a tragédia humana da segunda guerra mundial e a política antissemita do nazismo, trouxe o desafio de um novo olhar à humanidade, ao buscar consagrar os direitos humanos como fundamentados no reconhecimento da indivisibilidade e universalidade dos direitos à igualdade, à liberdade e à dignidade do ser humano, independente de sexo, cor, raça, religião e deficiência, passando a ser princípios fundamentais que deveriam ser respeitados pelas Nações ${ }^{\mathbf{1 6}}$. A partir de então, impulsionados principalmente pelos movimentos sociais organizados, políticas públicas de inclusão social de grupos discriminados começaram a ser discutidas, aprovadas e implementadas em boa parte das nações, incluindo o combate à discriminação e à exclusão social das pessoas com deficiência.

O Brasil, que tinha participado ativamente com os países aliados no combate ao regime nazista na segunda grande guerra, após 1948 sofreu grande influência para um atendimento especializado às pessoas com deficiência. Apesar das primeiras iniciativas anteriores na área da deficiência intelectual do movimento pestalozziano, vamos verificar que os primeiros serviços regulares de educação especial direcionados a crianças com deficiência

\footnotetext{
${ }^{16}$ COMPARATO, op. cit., p. 225.
} 
intelectual se deram a partir de 1950 com as Unidades Educacionais do Instituto Pestalozzi e as iniciativas do Governo Federal no período de 1957 a 1990, destinadas ao atendimento de desse público com impedimentos cognitivos. O grande problema dessa época é que os serviços eram de caráter assistencialista e não permitiam a independência da pessoa com deficiência. As crianças e adolescentes com deficiência intelectual permaneciam na sua maioria atreladas ao estabelecimento educacional especializado até a fase adulta, dependentes da instituição e de ações políticas assistenciais pontuais do poder público.

Nessa época, como dissidência do movimento pestalozziano surge a Associação de Pais e Amigos dos Excepcionais (APAE), que foi fundada por iniciativa de Beatrice Bemis, mãe de uma criança com deficiência intelectual, no ano de 1954. Em seguida, outros Estados foram fundando as suas APAEs locais, levando à criação em 1962 da Federação Nacional da APAEs (FENAPAES). Atualmente existem 23 federações estaduais e mais de duas mil APAEs por todo o país. A característica mais expressiva da APAE que justifica a extensão da sua expansão reside no fato de esta prestar serviços de saúde, educação e assistência social às pessoas que possuem deficiência intelectual e múltiplas.

Em se tratando dos centros de reabilitação, pode-se aqui mencionar a Associação Brasileira Beneficente de Reabilitação (ABBR), criada em 1954 pelo arquiteto Fernando Lemos, para atender à imensa demanda de pessoas acometidas pelos surtos de poliomielite, onde muitas tinham impedimentos intelectuais. Surtos de magnitude considerável aconteceram em cidades brasileiras na década de 1930 como, por exemplo, em Porto Alegre (1935), Santos (1937), São Paulo e Rio de Janeiro (1939). Surgiram ainda outras entidades com o intuito de minimizar as sequelas deixadas pela poliomielite como a Associação de Assistência à Criança Defeituosa (AACD) em 1950, hoje chamada de Associação de Assistência à Criança Deficiente, o Instituto Bahiano de Reabilitação (IBR), em Salvador no ano de 1956 e a Associação Fluminense de Reabilitação (AFR).

Neste período entre a década de 50 e final da de 60 foi marcado por estes serviços assistencialistas e de viés integrador, em escolas especiais, a parte do sistema educacional comum, sem garantia de independência para o aluno com deficiência intelectual, e principalmente sem estimulação à criança com deficiência para sua autonomia e inserção social. 


\subsection{Da transição da política de integração pela segregação para a da inclusão no atendimento ao aluno com deficiência intelectual}

A questão da organização política que é encontrada na história das pessoas com deficiência no Brasil, tem seu início com o fim do regime militar que perpetuou de 1964 até 1985, com a eleição de Tancredo Neves, após um período de 21 anos do militarismo autoritário diante das decisões governamentais. Diante dos constantes protestos que buscavam o declínio do regime militar, surgiam os movimentos sociais que ganhavam força à medida que o vigente regime enfraquecia. Com o fim da ditadura, aqueles que eram obrigados a permanecer silenciados pela opressão, iniciavam a sua luta por condições sociais mais favoráveis a população como um todo, e dentro destes grupos sociais, estavam inseridos os mais diversos tipos de indivíduos como mulheres, sem-teto, índios e também, as pessoas com deficiências. Eles passaram a ir em busca dos seus direitos participando ativamente, opinando e contribuindo para as discussões que iriam resultar em ações voltadas para a melhoria da sua qualidade de vida, deixando de ser apenas meros espectadores das decisões que iriam influenciar o seu cotidiano e passando a ser sujeitos com voz ativa no processo de mudanças que os envolveria enquanto pessoas com deficiência no geral.

Para adentrar na questão das medidas adotadas pelo governo brasileiro que apresentam como objetivo principal inserir o cidadão possuidor de alguma deficiência no sistema educacional, será exposto a seguir uma série de leis, decretos, planos, resoluções, portarias e convenções que foram criadas para garantir o direito da pessoa com deficiência, principalmente aqueles com deficiência intelectual, como diz a própria Constituição Federal Brasileira de 1988 em seu artigo 205: “A educação, direito de todos e dever do Estado e da família, será promovida e incentivada com a colaboração da sociedade, visando ao pleno desenvolvimento da pessoa, seu preparo para o exercício da cidadania e sua qualificação para o trabalho"17, o que ratifica que todos estão em pé de igualdade perante a lei, independente de possuir alguma particularidade ou não, sendo todos considerados cidadãos.

Em 1961, o atendimento educacional à pessoa com deficiência era fundamentado pelas disposições da antiga Lei de Diretrizes e Bases da Educação Nacional (LDBEN) - Lei no 4.024/61, que prescrevia formalmente o direito dos "excepcionais" à educação, preferencialmente dentro do sistema regular de ensino, porém de fato isso não ocorria, continuando os mesmos a serem atendidos em escolas ou unidades especializadas, na maioria

\footnotetext{
${ }^{17}$ BRASIL. Constituição (1988), op cit.
} 
de cunho particular ou filantrópicas. Em 1971, a Lei $\mathrm{n}^{\circ}$ 5.692/71, vem alterar a LBDEN de 1961 ao definir 'tratamento especial' para os alunos com deficiências físicas, mentais, os que encontram atraso considerável quanto à idade regular de matrícula e os superdotados"18, o que acaba por não promover uma organização de um sistema de ensino capaz de atender as necessidades educacionais especiais do aluno, reforçando o encaminhamento dos alunos com deficiência intelectual para as classes e escolas especiais. Dois anos mais tarde, em 1973, o Ministério da Educação (MEC), cria o Centro Nacional de Educação Especial (CENESP), que passa a ser o responsável pela gerência da educação especial no Brasil que, sob a égide integracionista impulsionou ações educacionais voltadas às pessoas com deficiência intelectual, mas ainda configuradas por campanhas assistenciais e iniciativas isoladas do estado.

Como já foi citado anteriormente, temos em 1988 a promulgação da Constituição Federal que traz como um dos seus objetivos fundamentais "promover bem de todos sem preconceito de origem, raça, sexo, cor, idade e quaisquer outras formas de discriminação" ${ }^{19}$ (artigo 3 - IV). Define no artigo 205, a educação como um direito de todos, garantindo o pleno desenvolvimento da pessoa. $\mathrm{O}$ exercício da cidadania e a qualificação para o trabalho. No seu artigo 206, inciso I, estabelece a "igualdade de condições de acesso e permanência na escola" como um dos princípios para um ensino e garante, como dever do estado, a oferta do atendimento educacional especializado, preferencialmente na rede regular de ensino (artigo 208). Diante desse novo paradigma da inclusão educacional de todas as crianças no ensino fundamental comum, cria-se embrionariamente o pensamento de uma política educacional inclusiva, onde todos estejam incluídos na mesma sala.

Em 1989, como consequência do advento da nova Carta Magna surge a Lei $n^{\circ} 7853$ de 20 de outubro de 1989, denominada de apoio a pessoa com deficiência, que em seu art. $2^{\circ}$ determina que é obrigação do Poder Público, entre outros deveres, garantir a educação a pessoa com deficiência, inclusive criminalizando em seu art. $8^{\circ}$, inciso I, qualquer ato que obste a matrícula e permanência do aluno com deficiência em estabelecimento de ensino comum, seja público ou particular.

\footnotetext{
${ }^{18}$ BRASIL. Decretos e Leis. Lei no 5.692 , de 11 de agosto de 1971. Fixa Diretrizes e Bases para o ensino de $1^{\circ} \mathrm{e}$ $2^{\circ}$ graus, e dá outras providências. Diário Oficial [da] República Federativa do Brasil, Brasília, 12 de agosto de 1971. Disponível em: https://www.planalto.gov.br/ccivil_03/leis/L5692.htm. Acesso em: 28.08.2014.

${ }^{19}$ BRASIL (1988), op cit., Art. 3.
} 
Em 1990, encontra-se no Estatuto da Criança e do Adolescente (ECA - Lei $\mathrm{n}^{\circ}$ 8.069/90), no artigo 55, o reforço dos dispositivos legais supracitados ao determinar que "os pais ou responsáveis tem a obrigação de matricular seus filhos ou pupilos na rede regular de ensino"20. Também nessa década, documentos como a Declaração Mundial de Educação para Todos (1990) e a Declaração de Salamanca (1994) passam a influenciar a formulação das políticas públicas da educação inclusiva.

Diante desse novo panorama nacional na educação, é publicada em 1994, a Política Nacional de Educação Especial, orientando o processo de "integração instrucional" que condiciona o acesso a classes comuns do ensino regular aqueles que "[...] possuem condições de acompanhar e desenvolver as atividades curriculares programas do ensino comum, no mesmo ritmo que os alunos ditos normais" ${ }^{21}$. Ao reafirmar os pressupostos construídos a partir de padrões homogêneos de participação e aprendizagem, a política não provoca uma reformulação das práticas educacionais de maneira que sejam valorizados os diferentes potenciais de aprendizagem do ensino comum, mas mantendo a responsabilidade da educação desses alunos exclusivamente no âmbito da educação especial.

A atual Lei das Diretrizes e Bases da Educação Nacional, Lei no 9. 394/96, que surge neste período, influenciado pelos ares democráticos da Carta Magna e da Declaração de Salamanca, no art. 59, preconiza que os sistemas de ensino devem assegurar aos alunos com necessidades educacionais especiais currículo, métodos, recursos e organização específica para atender suas necessidades; assegura a terminalidade específica àqueles que não atingiram o nível exigido para o Ensino Fundamental, em virtude de suas deficiências e assegura a aceleração de estudos aos superdotados para conclusão do programa escolar. Também, dentre as normas para a organização da educação básica, a "possibilidade de avanço nos cursos e nas séries mediante verificação do aprendizado" "22 (art. 24, V) e "[...] oportunidades educacionais apropriadas, consideradas as características do alunado, seus interesses, condições de vida, de trabalho, mediante cursos e exames" (art. 37) ${ }^{23}$. Assim, a atual LDBEN vem afirmar o direito

20 BRASIL. Decretos e Leis. Lei no 8.069, de 13 de julho de 1990. Dispõe sobre o Estatuto da Criança e do Adolescente e dá outras providências. Diário Oficial [da] República Federativa do Brasil. Brasília, 14 de julho de 1990. Disponível em: https://www.planalto.gov.br/ccivil_03/leis/L8069.htm. Acessoem: 06.03.2013.

21 BRASIL. Ministério da Educação. Secretaria de Educação Especial. Política Nacional de Educação Especial. Brasília: MEC/SEESP, 1994.

22 BRASIL. Decretos e Leis. Lei $n^{\circ}$ 9.394, de 20 de dezembro de 1996. Estabelece as diretrizes e bases da educação nacional. Diário Oficial [da] República Federativa do Brasil. Brasília, 21 de dezembro de 1996. Disponível em: https://www.planalto.gov.br/ccivil_03/Leis/L9394.htm. Acesso em: 21.12.2012. Art. 24.

${ }^{23}$ BRASIL, op. cit., 1996, Art. 37. 
de as crianças com impedimentos cognitivos de estarem junto com os demais alunos nas classes regulares, interagindo e buscando, com os apoios da educação especial, sua autonomia e independência.

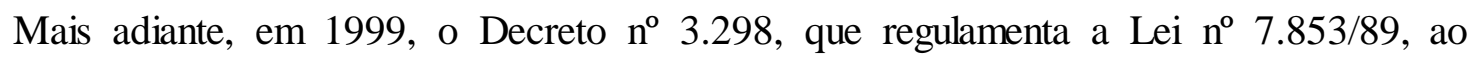
dispor sobre a política nacional para a integração da pessoa portadora de deficiência, define a educação especial como uma modalidade transversal a todos os níveis e modalidades de ensino, enfatizando a atuação complementar da educação especial ao ensino regular.

Acompanhando o processo de mudança, as Diretrizes Nacionais para a Educação Especial na Educação Básica, resolução CNE/CEB nº 02/2001, no art. 2º determina que: "os sistemas de ensino devem matricular todos os alunos, cabendo às escolas organizarem-se para o atendimento dos educandos com necessidades educacionais especiais, assegurando as condições necessárias para uma educação de qualidade para todos" ${ }^{24}$.

As Diretrizes ampliam o caráter de educação especial para realizar o atendimento educacional especializado complementar ou suplementar à escolarização, porém, ao admitir a possibilidade de substituir o ensino regular, não potencializam a adoção de uma política de educação inclusiva na rede pública de ensino, prevista em seu art. $2^{\circ}$.

O Plano Nacional de Educação - PNE, Lei n ${ }^{\circ} 10.172 / 01$, destaca que "o grande avanço que a década da educação deveria produzir seria a construção de uma escola inclusiva que garanta o atendimento à diversidade humana"25. Ao estabelecer objetivos e metas para que os sistemas de ensino favoreçam o atendimento às necessidades educacionais especiais dos alunos, aponta um déficit referente à oferta de matrícula para alunos com deficiência nas classes comuns do ensino regular, à formação docente, à acessibilidade física e ao atendimento educacional especializado.

A Convenção de Guatemala (1999), promulgada no ordenamento jurídico pátrio pelo Decreto $\mathrm{n}^{\mathrm{o}}$ 3.956/01, afirma que as pessoas com deficiência têm os mesmos direitos humanos e liberdades fundamentais que as demais pessoas, definindo como discriminação com base na deficiência toda discriminação ou exclusão que possa impedir ou anular o exercício de tais direitos humanos e liberdades fundamentais. Esta Convenção tem importante repercussão na

\footnotetext{
24 BRASIL. Ministério da Educação. CNE/CEB. Resolução CNE/CEB $n^{\circ} 2$, de 11 de setembro de 2001. Institui Diretrizes Nacionais para a Educação Especial na Educação Básica. 2001. Disponível em: http://portal.mec.gov.br/cne/arquivos/pdf/CEB0201.pdf. Acesso em: 09.11.2012.

25 BRASIL. Decretos e Leis. Lei n ${ }^{\circ}$ 10.172, de 9 de janeiro de 2001. Aprova o Plano Nacional de Educação e dá outras providências. Diário Oficial [da] República Federativa do Brasil. Brasília, 10 de janeiro de 2001. Disponível em: http://www.planalto.gov.br/ccivil_03/leis/LEIS_2001/L10172.htm. Acesso em: 21.12.2012.
} 
educação, exigindo uma reinterpretação da educação especial, compreendida no contexto da diferenciação, adotada para promover a eliminação das barreiras que impedem o acesso à escolarização.

Na perspectiva da educação inclusiva, a Resolução CNE/CP n $1 / 2002$, que estabelece as Diretrizes Curriculares nacionais para a formação de Professores da Educação Básica, define que as instituições de ensino superior devem prever, em sua organização curricular, formação docente voltada para a tensão à diversidade e que contemple conhecimentos sobre as especificidades dos alunos com necessidades educacionais especiais.

Em 2003, é implementado pelo MEC o Programa Educação Inclusiva que dispõe direito à universidade, com vistas a apoiar a transformação dos sistemas de ensino em sistemas educacionais inclusivos, promovendo um amplo processo de formação de gestores e educadores nos municípios brasileiros para a garantia do direito de acesso de todos à escolarização, a oferta do atendimento educacional especializado e a garantia da acessibilidade.

Em 2004, O Ministério Público Federal (MPF) publica o documento:

O Acesso de Alunos com Deficiência às Escolas e Classes Comuns da Rede Regular, com o objetivo de disseminar os conceitos e diretrizes mundiais para a inclusão, reafirmando o direito e os benefícios da escolarização de alunos come sem deficiência nas turmas comuns de ensino regular ${ }^{26}$.

Impulsionando a inclusão educacional e social, o Decreto $\mathrm{n}^{\circ} 5.296 / 04$ regulamentou as Leis $\mathrm{n}^{\circ} 10.048 / 00$ e $\mathrm{n}^{\mathrm{o}} 10.098 / 00$, estabelecendo normas e critérios para a promoção da acessibilidade às pessoas com deficiência ou com mobilidade reduzida. Nesse contexto, o Programa Brasil Acessível, do Ministério das Cidades, é desenvolvido com o objetivo de promover a acessibilidade urbana e acesso universal aos espaços públicos.

A Convenção sobre os Direitos das Pessoas com Deficiência, aprovada pela Organização das Nações Unidas (ONU) em 2006 e da qual o Brasil é signatário, e que é referendada pelo Congresso Nacional pelo Decreto Legislativo n.186/2008, com efeito de emenda constitucional, é um marco na afirmação dos direitos humanos das pessoas com deficiência, e estabelece que os Estados-Parte devem assegurar um sistema de educação inclusiva em todos os níveis de ensino, em ambientes que maximizem o desenvolvimento

\footnotetext{
26 BRASIL. Ministério Público Federal. O Acesso de alunos com deficiência às escolas e classes comuns da rede regular. 2. ed. rev. e atual. Brasília: Procuradoria Federal dos Direitos do Cidadão, 2004.
} 
acadêmico e social compatível com a meta da plena participação e inclusão, adotando medida para garantir que:

\begin{abstract}
a) As pessoas com deficiência não sejam excluídas do sistema educacional geral sob a alegação de deficiência e que as crianças com deficiência não sejam excluídas do ensino fundamental gratuito e compulsório, sob ale gação de deficiência;

b) As pessoas com deficiência possam ter acesso ao ensino fundamental inclusivo, de qualidade, gratuito, em igualdade condição com as demais pessoas na comunidade em que vivem (art.24). ${ }^{27}$
\end{abstract}

Nesse mesmo ano de 2006, a Secretaria Especial dos Direitos Humanos, os Ministérios da Educação e Justiça, juntamente com a Organização das Nações Unidas para a Educação, a Ciência e a Cultura (UNESCO), lançam o Plano Nacional de Educação em Direitos Humanos, que objetiva, dentre as suas ações, contemplar, no currículo da educação básica, temáticas relativas às pessoas com deficiência e desenvolver ações afirmativas que possibilitem acesso e permanência na educação superior.

Em 2007, é lançado o Plano de Desenvolvimento da Educação (PDE), reafirmando a Agenda Social, tendo como eixos à formação de professores para a educação especial, a implantação de salas de recursos multifuncionais, a acessibilidade arquitetônica dos prédios escolares, acesso a permanência das pessoas com deficiência na educação superior e o monitoramento do acesso à escola dos favorecidos pelo Benefício de Prestação Continuada (BPC), benefício assistencial de um salário mínimo a pessoa com deficiência pobre com impedimentos para trabalhar, o que abrange as crianças com deficiência intelectual.

Para a implantação do PDE é publicado o Decreto $n^{\circ}$ 6.094/07, que estabelece nas diretrizes do Compromisso de Todos pela Educação, a garantia do acesso e permanência no ensino regular e o atendimento às necessidades educacionais especiais dos alunos com deficiência, fortalecendo seu ingresso nas escolas públicas.

O Decreto $\mathrm{n}^{\circ}$ 6.571/08 dispõe sobre o atendimento educacional especializado, definindo no $\S 1^{\mathrm{o}}$ do art. $1^{\mathrm{o}}$, como o conjunto de atividades, recursos de acessibilidade e pedagógicos organizados institucionalmente e prestados de forma complementar ou suplementar à formação dos alunos no ensino regular.

No $\S 2^{\circ}$ do art. $1^{\circ}$, desse supracitado decreto, determina que o Atendimento Educacional Especializado (AEE) integra a proposta pedagógica da escola, envolvendo a

\footnotetext{
27 BRASIL. Congresso Nacional. Decreto legislativo $n^{\circ} 186$, de 09 de julho de 2008. Aprova o texto da Convenção sobre os Direitos das Pessoas com Deficiência e de seu Protocolo Facultativo, assinados em Nova Iorque, em 30 de março de 2007. Diário Oficial [da] República Federativa do Brasil. Brasília, 10 de julho de 2008. Disponível em: http://www.justicaeleitoral.jus.br/arquivos/tre-al-decreto-legislativo-186-2008. Acesso em: 21.12.2012.
} 
participação da família e a articulação com as demais políticas públicas. No art. $9^{\circ}$, dispõe do apoio técnico e financeiro da União para ampliar a oferta do atendimento educacional especializado, regulamentando, para efeito da distribuição dos recursos do FUNDEB, o cômputo das matrículas dos alunos da educação regular da rede pública que recebem atendimento educacional especializado sem prejuízo do cômputo dessas matrículas da educação básica regular. No art. $3^{\circ}$, dispõe a implantação das salas de recursos multifuncionais, definidas como "ambientes dotados de equipamentos, mobiliários e materiais didáticos para a oferta do atendimento educacional especializado".

A Resolução CNE/CEB No 4/2009 com a finalidade de implementar o Decreto $\mathrm{n}^{\circ}$ $6.571 / 2008$, no art. $1^{\circ}$, estabelece que os sistemas de ensino devem matricular os alunos público alvo da educação especial nas classes comuns do ensino regular e no atendimento educacional especializado, ofertado em salas de recursos multifuncionais ou centros de atendimento educacional especializado da rede pública ou de instituições comunitárias, confessionais ou filantrópicas sem fins lucrativos.

No art. $4^{\circ}$ define o público alvo de AEE como:

I - Alunos com deficiência "aqueles que têm impedimentos de longo prazo de natureza física, intelectual, mental ou sensorial";

II - Alunos com transtornos globais do desenvolvimento "aqueles que apresentam um quadro de alterações no desenvolvimento neuropsicomotor, comprometimento nas relações sociais, na comunicação ou estereotipias motoras". Incluem-se nessa definição alunos com autismo clássico, síndrome de Asperger, síndrome de Rett, transtorno desintegrativo da infância (psicoses) e transtornos invasivos sem outras especificações;

III - Alunos com altas habilidades/superdotação "aqueles que apresentam um potencial elevado e grande envolvimento com as áreas de conhecimento humano, is oladas ou combinadas, intelectual, liderança, psicomotora, artes e criatividade". ${ }^{28}$

Em 2011, o Decreto $n^{\circ} 7.611 / 11$ revoga o Decreto $n^{\circ} 6.571 / 08$ e passa a regular a educação especial, ou seja, o atendimento educacional especializado aos alunos com deficiência intelectual, sendo este ainda hoje a norma reguladora de tais questões.

Em 3 de janeiro de 2016 entra em vigor a Lei 13.146/2005, denominada Lei da Inclusão ou Estatuto da Pessoa com Deficiência, que nos seus artigos 28 a 30 regulamenta aspectos da educação inclusiva aos alunos com deficiência e reforça a política da educação especial na perspectiva da educação inclusiva.

\footnotetext{
28 BRASIL. Ministério da Educação. Câmara de Educação Básica. Resolução no 4, de 2 de outubro de 2009. Institui Diretrizes Operacionais para o Atendimento Educacional Especializado na Educação Básica, modalidade Educação Especial. Disponível em: http://www.abiee.org.br/doc/Resolu\%E7\%E3o\%204\%20DE\%2002\%20ou t\%202009\%20EDUCA\%C7\% C3O\% 20ESPECIAL\% 20rceb004_09.pdf. Aces so em: 01.04.2013.
} 
Atualmente a Secretária de Educação Continuada, Alfabetização, Diversidade e Inclusão (SECADI) junto ao Ministério da Educação (MEC) é o órgão da administração direta federal que possui a finalidade de implementar políticas educacionais nas áreas de alfabetização e educação de jovens e adultos, educação ambiental, educação em direitos humanos, educação especial, do campo, escolar indígena, quilombola e educação para as relações étnico-raciais.

Nos estados e municípios, devido a descentralização da política educacional no País e autonomia federativa dos entes, cada estado e cada município tem seu plano educacional e suas metas em relação a educação de crianças com deficiência, porém sempre pautado nas diretrizes educacionais nacionais e no ordenamento jurídico nacional.

Desta forma detalhamos mais abaixo esses documentos norteadores da política educacional inclusiva que deve ser seguida pela Escola Estadual Marta da Conceição, em Cotijuba, Icoaraci, Belém, Pará, objeto da pesquisa.

\subsection{Documentos norteadores da política educacional inclusiva}

\subsubsection{Declaração de Salamanca}

$\mathrm{Na}$ seção anterior, fizemos uma breve apresentação histórica das medidas legais e políticas que foram implementadas afim de melhor tratar do tema da educação especial no contexto brasileiro, principalmente em relação aos alunos infantes com deficiência intelectual. Porém, é importante que se esmiúce mais detalhadamente sobre aquelas que hoje são as reguladoras da política no contexto nacional, se voltando também para maiores informações no que tange o contexto regional, que nesta produção se caracteriza como a situação do Estado do Pará, onde se localiza a escola objeto da pesquisa.

Para iniciarmos falaremos desta que perpetuou tempo suficiente para se tornar significativa para a questão das pessoas com deficiência, denominada Declaração de Salamanca.

Este documento ${ }^{29}$ foi elaborado na Conferência Mundial sobre Educação Especial, em Salamanca, na Espanha, em 1994, no qual participou representantes de 88 governos e 25

29 NAÇÕES UNIDAS. Declaração de Salamanca: Sobre Princípios, Políticas e Práticas na Área das Necessidades Educativas Especiais. 1994. Disponível em: http://portal.mec.gov.br/seesp/arquivos/pdf/salaman ca.pdf. Acesso em: 02.02.2013. 
organizações internacionais e apresentou como objetivo fornecer diretrizes básicas para a formulação e reforma de políticas e sistemas educacionais de acordo com o movimento de inclusão, sendo considerado um dos principais documentos mundiais que visam à inclusão social, ao lado da Convenção de Direitos da Criança (1988) e da Declaração sobre Educação para Todos de 1990. Ela é o resultado de uma tendência mundial que consolidou a educação inclusiva, e cuja origem tem sido atribuída aos movimentos de direitos humanos e de desinstitucionalização manicomial que surgiram a partir das décadas de 60 e 70.

Portanto, o encontro realizado em Salamanca, aconteceu como uma medida para saciar a necessidade urgente apresentada pelos dados estatísticos que impressionavam negativamente a realidade da educação mundial, evidenciando o quanto era imprescindível que se implantasse ações que efetivasse a educação para todos, se atendo principalmente para a situação das pessoas com deficiência. Conforme Ivanilde Apoluceno Oliveira:

[...] Essa declaração internacional expressam um movimento em favor de uma educação inclusiva, que teve inicio nos Estados Unidos, cujo marco histórico foi a Lei Pública 94.142 de 1975. No final da década de 1970 e inicio dos anos 1980, nos Estados Unidos, alunos com deficiência começaram a receber serviços educacionais em escolas regulares de seus bairros. E as décadas de 1980 e 1990 foram marcadas pela intensificação da luta pela inserção do/a aluno/a com necessidades es peciais no ensino regular. [...] Nos anos 1990, esse movimento inclusivo ganhou ímpeto pela organização internacional crescente, inclusive sendo estendida para fora do campo da educação especial e nos tribunais, objetivando a reforma geral no sistema educacional, tendo como pressuposto a "educação para todos". 30

Conclui-se que a sua importância histórica se deve em grande parte por ser um dos primeiros documentos que propõem uma escola inclusiva. Uma das implicações educacionais orientadas a partir da Declaração de Salamanca refere-se à inclusão na educação. Segundo o documento,

[...] o princípio fundamental da escola inclusiva é o de que todas as crianças deveriam aprender juntas, independentemente de quaisquer dificuldades ou diferenças que possam ter. As escolas inclusivas devem reconhecer e responder às diversas necessidades de seus alunos, acomodando tanto estilos como ritmos diferentes de aprendizagem e assegurando uma educação de qualidade a todos através de currículo apropriado, modificações organizacionais, estratégias de ensino, uso de recursos e parceiras com a comunidade [...] Dentro das escolas inclusivas, as crianças com necessidades educacionais especiais deveriam receber qualquer apoio extra que possamprecisar, para que se lhes assegure uma educação efetiva $[\ldots]^{31}$.

30 OLIVEIRA, Ivanilde Apoluceno. Saberes, imaginários e representações na educação especial. $2^{\mathrm{a} e d .}$ Petrópolis: Ed. Vozes, 2004. p.72-73.

${ }^{31}$ Nações Unidas, op cit. 
Este documento internacional deveria ser seguido ao determinar uma educação inclusiva às pessoas com deficiência a mais satisfatória possível, voltando-se a outras questões que até então eram deixadas de lado pela maior parte dos países, incluindo o Brasil. Um dos primeiros reflexos proporcionados pela Declaração de Salamanca acontecidos aqui no Brasil se apresenta com a promulgação da Lei de Diretrizes e Bases da Educação (LDB 9.394/96), em 1996, que reformulou seu texto determinando que especiais deveriam ser os currículos, os métodos, as técnicas, os recursos e a organização específicos para atender a necessidade dos alunos, passando por cima do tratamento excludente que era oferecido ao "aluno especial". Podemos citar ainda como outras ações que incorporaram os princípios e orientações da Declaração de Salamanca, o Plano Nacional de Educação (Lei 10.172/01) e as Diretrizes Nacionais para a Educação Especial na Educação Básica (Resolução CNE/CEB nº. 02/01).

Entende- se, portanto, que apesar de não haver consenso quanto à participação efetiva do Brasil na Conferência Mundial sobre Necessidades Educacionais Especiais e de não ter referendado todos os pontos ali definidos, a Declaração de Salamanca influenciou - e ainda influencia - fortemente a política e a gestão da educação nacional, sobretudo da educação especial.

2.3.2 A Convenção sobre os direitos da pessoa com deficiência e a política nacional de educação especial na perspectiva da educação inclusiva

Após este passo fundamental proporcionado pelas orientações da Declaração de Salamanca, outras ações foram acontecendo trazendo cada vez mais à luz a necessidade de medidas urgentes que a educação especial demandava. Em 2006, foi aprovada a Convenção sobre os Direitos da Pessoa com deficiência, sendo o Brasil um de seus signatários, que juntamente com a Política Nacional de Educação Especial na Perspectiva da Educação Inclusiva e os artigos. 28 a 30 da Lei n. 13.146/2015, são atualmente os documentos norteadores principais da questão da educação especial no Brasil. Por isso mesmo, passamos a examiná-los mais detidamente a seguir.

A Convenção das Nações Unidas sobre os Direitos das Pessoas com Deficiência representa um importante marco em prol da segurança dos direitos e liberdades fundamentais desta minoria. Aprovada pela Assembleia Geral das Nações Unidas em 6 de dezembro de 2006, juntamente com seu Protocolo Facultativo, entrou em vigor em 3 de maio de 2008 (como previu o seu art. 45, número 1). Contudo, no plano jurídico nacional brasileiro, a 
observância da Convenção somente se deu com a promulgação do Decreto $n^{\circ}$ 6.949, de 25 de agosto de $2009^{32}$.

A Convenção sobre os Direitos das Pessoas com Deficiência também possui a peculiaridade de ser o primeiro acordo internacional a ser aprovado na forma exigida pelo $\$ 3^{\circ}$ do art. 5', Constituição Federal - criado pela Emenda Constitucional 45/2004: “Os tratados e convenções internacionais sobre direitos humanos que forem aprovados, em cada Casa do Congresso Nacional, em dois turnos, por três quintos dos votos dos respectivos membros, serão equivalentes às emendas constitucionais." ${ }^{33}$ De tal sorte, a Convenção foi elevada ao patamar normativo-hierárquico das emendas à Constituição, ou seja, está acima das leis complementares e ordinárias - significa que, entre outras coisas, na hipótese de conflito entre a Convenção e a lei infraconstitucional, a primeira prevalece. Representa, ainda, uma importante mudança de paradigma, deixando de lado o fato das pessoas com deficiência serem vistas como objetos de caridade, para visualizá-las como titulares de direitos. E, com este arquétipo, são sujeitos capazes de reivindicá-los, permitindo a proatividade na tomada de decisões para suas vidas com base em seu consentimento livre e esclarecido, bem como de serem membros ativos da sociedade.

O artigo $1^{\circ}$ da Convenção expõe o seu Propósito dizendo o seguinte:

\begin{abstract}
Artigo 1 - Propósito
O propósito da presente Convenção é o de promover, proteger e as seguraro desfrute pleno e eqüitativo de todos os direitos humanos e liberdades fundamentais por parte de todas as pessoas com deficiência e promover o respeito pela sua inerente dignidade.

Pessoas com deficiência são aquelas que têm impedimentos de natureza física, intelectual ou sensorial, os quais, em interação com diversas barreiras, podem obstruir sua participação plena e efetiva na sociedade com as demais pessoas ${ }^{34}$.
\end{abstract}

\footnotetext{
32 Diz-se de tal forma, pois, à luz do entendimento firmado em sede do Supremo Tribunal Federal na CR 8.279 e na ADI 1.480. Ocasião em que se enfatizou que somente o decreto presidencial conclui o procedimento constitucional de incorporação dos acordos internacionais ao plano jurídico doméstico, pois que tal documento (decreto presidencial) confere ao tratado os efeitos básicos de promulgação, publicação oficial e executoriedade.

33 BRASIL. Decretos e Leis. Decreto nº 6.949, de 25 de agosto de 2009. Promulga a Convenção Internacional sobre os Direitos das Pessoas com Deficiência e seu Protocolo Facultativo, assinados em No va York, em 30 de março de 2007. Diário Oficial [da] República Federativa do Brasil. Brasília, 26 de agosto de 2009. Disponível em: http://www.planalto.gov.br/ccivil_03/_Ato2007-2010/2009/Decreto/D6949.htm. Acesso em: 21.12.2012.

34 BRASIL. Secretaria de Direitos Humanos Secretaria Nacional de Promoção dos Direitos da Pessoa com Deficiência. Convenção sobre os Direitos das Pessoas com Deficiência. 4. ed., rev. e atual. Brasília : Secretaria de Direitos Humanos, Secretaria Nacional de Promoção dos Direitos da Pessoa com Deficiência, 2012. Disponível em: http://www.pes soacomdeficiencia.gov.br/app/sites/default/files/publicacoes/convencaope ssoas comdeficiencia.pdf. Acesso em: 25.01.2013.
} 
$\mathrm{Na}$ análise do art. $1^{\circ}$, percebe-se que a Convenção não tratou de elencar um novo rol de direitos humanos em favor das pessoas com deficiência. Mas sim - com o fito de apontar para uma direção em que tais pessoas possam gozar plenamente dos direitos humanos e fundamentais já preexistentes - de afirmar um princípio geral de igualdade, explicitando também o conceito e a denominação mais coerentes que hoje deve estar atento às pessoas com deficiência.

De certo, o princípio de igualdade não mais poderia exigir, no imperativo de sua exequibilidade, uma postura ${ }^{35}$ do igual tratamento (no sentido de tratamento idêntico) em que se desconhecessem as diferenças específicas que o próprio direito determina cuidado próprio. Qualquer mandamento nesse sentido seria um flagrante vilipendio à dignidade intrínseca da pessoa humana que, em virtude de sua diferença, fosse colocada em posição diversa dos demais em decorrência da aplicação desta norma. Assim, é o próprio princípio da igualdade, em uma leitura bem mais complexa, que requer o tratamento específico, consentâneo e diferenciado. Adequado às diferenças concretas.

Neste diapasão, a igualdade eleita pela Convenção é a igualdade da igual consideração e respeito ${ }^{36}$. Porquanto, na medida em que o Estado trata os cidadãos com a mesma consideração, o faz com um olhar sensível às condições diferenciadas de cada sujeito, permitindo-lhes o devido acesso aos direitos humanos e liberdades fundamentais e aos meios necessários à obtenção de seus ideais de vida.

$\mathrm{O}$ artigo $2^{\circ}$ também merece destaque devido a sua importância, pois é neste que ficam especificadas as "Definições" sobre alguns requisitos fundamentais para a temática das pessoas com deficiência. Ele está na Convenção da seguinte maneira:

\section{Artigo 2 - Definições}

Para os propósitos da presente Convenção:

"Comunicação" abrange as línguas, a visualização de textos, o braile, a comunicação tátil, os caracteres ampliados, os dispositivos de multimídia acessível, assim como a linguagem simples, escrita e oral, os sistemas auditivos e os meios de voz digitalizada e os modos, meios e formatos aumentativos e alternativos de comunicação, inclusive a tecnologia da informação e comunicação;

"Língua" abrange as línguas faladas e de sinais e outras formas de comunicação nãofalada;

\footnotetext{
35 Aqui devemos lembrar que tal postura, no contexto dos acordos internacionais acerca de direitos humanos, é instado em relação ao Estado-parte, ou seja, se está falando sobre o modo como o Estado, especialmente, deve tratar com o cidadão (âmbito de moralidade política). Este enfoque permite uma melhor compreensão, à luz de sua finalidade, desta espécie de ajuste internacional.
}

${ }^{36}$ Está é a posição defendida em: DWORKIN, Ronald. O Império do Direito. Martins Fontes. São Paulo, 2010. 


\begin{abstract}
"Discriminação por motivo de deficiência" significa qualquer diferenciação, exclusão ou restrição baseada em deficiência, com o propósito ou efeito de impedir ou impossibilitar o reconhecimento, o desfrute ou o exercício, em igualdade de oportunidades com as demais pessoas, de todos os direitos humanos e liberdades fundamentais nas esferas política, econômica, social, cultural, civil ou qualquer outra. Abrange todas as formas de discriminação, inclusive a recusa de adaptação razoável;

"Ajustamento razoável" significa a modificação necessária e adequada e os ajustes que não acarretem um ônus desproporcional ou indevido, quando necessários em cada caso, a fim de assegurar que as pessoas com deficiência possam desfrutar ou exercitar, em igualdade de oportunidades com as demais pessoas, todos os direitos humanos e liberdades fundamentais;

"Desenho universal" significa o projeto de produtos, ambientes, programas e serviços a serem usados, na maior medida possível, por todas as pessoas, sem que seja necessário um projeto especializado ou ajustamento. O "desenho universal" não deverá excluir as ajudas técnicas para grupos específicos de pessoas com deficiência, quando necessárias ${ }^{37}$.
\end{abstract}

A Convenção teve o cuidado de estabelecer conceitos básicos extremamente relevantes que perpassam a questão. Pode até parecer desnecessário, porém quem se envolve diretamente com as pessoas com deficiência, principalmente as com impedimento intelectual, sabe a importância fundamental que é definir de fato estes conceitos acima apresentados. Os próprios termos utilizados para qualificar "os alunos com necessidades educacionais especiais" apresentaram uma evolução, indo desde adjetivos pejorativos como "retardado", "mongolóide", passando por outros mais brandos como "portadores de necessidades especiais" até se chegar no trato que é colocado na Convenção que se defini em somente "pessoas com deficiência".

Continuando ainda sobre a análise deste que hoje se apresenta como o documento norteador das questões relacionadas às pessoas com deficiência, encontramos no artigo $24 \mathrm{o}$ ponto chave para esta produção.

$\mathrm{O}$ artigo 24, intitulado como Educação trata das ações a serem seguidas para que se proporcione uma educação inclusiva, reafirmando o direito a uma educação sem discriminação e com igualdade de oportunidades. Ficam estabelecidos como objetivos:

a. O pleno desenvolvimento do potencial humano e do senso de dignidade e autoestima, além do fortalecimento do respeito pelos direitos humanos, pelas liberdades fundamentais e pela diversidade humana;

b. O desenvolvimento máximo possível personalidade e dos talentos e criatividade das pessoas com deficiência, assim de suas habilidades físicas e intelectuais;

c. A participação efetiva das pessoas comdeficiência em uma sociedade livre ${ }^{38}$.

\footnotetext{
37 BRASIL, 2012, op cit.

38 Id., Ibid.
} 
Fica esclarecido ainda que para a realização deste direito deve ser assegurado que:

a. As pessoas com deficiência não sejam excluídas do sistema educacional geral sob alegação de deficiência e que as crianças com deficiência não sejam excluídas do ensino fundamental gratuito e compulsório, sob a alegação de deficiência;

b. As pessoas com deficiência possam ter acesso ao ensino fundamental inclusivo, de qualidade e gratuito, em igualdade de condições com as demais pessoas na comunidade em que vivem;

c. Adaptações razoáveis de acordo com as necessidades individuais sejam providenciadas;

d. As pessoas com deficiência recebam o apoio necessário, no âmbito do sistema educacional geral, com vistas a facilitar sua efetiva educação; e

e. Efetivas medidas individualizadas de apoio sejam adotadas em ambientes que maximizem o desenvolvimento acadêmico e social, compatível com a meta de inclusão plena ${ }^{39}$.

É colocado ainda sobre as medidas apropriadas que os Estados Parte deverão adotar para facilitar a plena e igual participação na educação como:

a. Facilitação do aprendizado do braile, escrita alternativa, modos, meios e formatos de comunicação aumentativa e alternativa, e habilidades de orientação e mobilidade, além de facilitação do apoio e aconselhamento de pares;

b. Facilitação do aprendizado da língua de sinais e promoção da identidade lingüística da comunidade surda; e

c. Garantia de que a educação de pessoas, inclusive crianças cegas, surdocegas e surdas, seja ministrada nas línguas e nos modos e meios de comunicação mais adequados às pessoas e em ambientes que favoreçam ao máximo seu desenvolvimento acadêmico e social ${ }^{40}$.

O artigo 24 é concluído fazendo considerações sobre medidas apropriadas para que se empreguem professores, incluindo docentes com deficiências, habilitados para o ensino da língua de sinais e/ou do braile, capacitação de profissionais que vise incorporar a conscientização da deficiência, assim como utilizar formatos de comunicação aumentativa e alternativa, técnicas e materiais pedagógicos que auxiliem no desenvolvimento geral da pessoa com deficiência. Pontua ainda que deve ser igualmente assegurado, promovendo as adaptações necessárias, mesmo que em condições razoáveis, o acesso à educação comum nas modalidades de ensino superior, treinamento profissional, educação de jovens e adultos e aprendizado continuado, sem discriminação e em iguais condições com as demais pessoas. É válido ainda ressaltar que a inclusão e o respeito à diversidade é aprendido também pelos alunos sem deficiência que na convivência com os alunos deficientes, compreendem os impedimentos daqueles e ajudam a si próprios e os demais, compartilhando assim do

\footnotetext{
${ }^{39}$ BRASIL, 2012, op cit.

${ }^{40} \mathrm{Id}$,
} 
princípio de uma sociedade inclusiva, onde todos podem viver harmoniosamente e disseminando a prática do respeito.

Em relação a denominada Política Nacional de Educação Especial na Perspectiva da Educação Inclusiva, este é um documento elaborado pelo Grupo de Trabalho nomeado pela Portaria Ministerial $\mathrm{n}^{\mathrm{o}} 555$, de 5 de junho de 2007, prorrogada pela Portaria $\mathrm{n}^{\circ} 948$ de 09 de outubro de 2007 e em suma busca:

[...] acompanhar os avanços do conhecimento e das lutas sociais, vis ando constituir políticas públicas promotoras de uma educação de qualidade para todos os alunos e apresenta como objetivo o acesso, a participação e a aprendizagem dos alunos com deficiência, transtornos globais do desenvolvimento e altas habilidades/superdotação nas escolas regulares, orientando os sistemas de ensino para promover respostas às necessidades educacionais especiais, garantindo: transversalidade da educação especial desde a educação infantil até a educação superior; atendimento educacional especializado; continuidade da escolarização nos níveis mais elevados do ensino; formação de professores para o atendimento educacional especializado e demais profissionais da educação para a inclusão escolar; participação da família e da comunidade; acessibilidade urbanística, arquitetônica, nos mobiliários e equipamentos, nos transportes, na comunicação e informação; e articulação intersetorial na implementação das políticas públicas. ${ }^{41}$

O seu discurso é iniciado discorrendo sobre Marcos Históricos e Normativos no que tangem a educação especial, apresentando todo o aparto histórico que já foi exposto anteriormente. $\mathrm{O}$ tópico seguinte é essencial para uma visualização mais compreensiva e clara do como de fato a educação especial está sendo tratada no Brasil. É apresentado um Diagnóstico da Educação Especial com dados retirados do Censo Escolar/MEC/INEP. O Censo Escolar é realizado anualmente em todas as escolas da educação básica, o que permite o acompanhamento dos dados relacionados à educação especial. Para realizar um acompanhamento mais completo, prima-se por analisar algumas questões fundamentais para obter a realidade da educação oferecida às pessoas com deficiência.

Para compor esses indicadores no âmbito da educação especial, o Censo Escolar/MEC/INEP coleta dados referentes ao número geral de matrículas; à oferta da matrícula nas escolas públicas, escolas privadas e privadas sem fins lucrativos; às matrículas em classes especiais, escola especial e classes comuns de ensino regular; ao número de alunos do ensino regular com atendimento educacional especializado; às matrículas, conforme tipos de deficiência, transtornos do desenvolvimento e altas habilidades/superdotação; à infra-estrutura das escolas quanto à acessibilidade

${ }^{41}$ BRASIL, 2008, op. cit. 
arquitetônica, à sala de recursos ou aos equipamentos específicos; e à formação dos professores que atuam no atendimento educacional especializado. ${ }^{42}$

Os dados obtidos através do Censo Escolar apresentam uma evolução considerável sobre o crescimento da educação especial. Os dados apontam que em 1998, existiam 337.326 crianças com deficiências matriculadas e foi dado um salto para o ano de 2006 que registrou 700.624 matriculas, expressando um crescimento de 107\%. Em relação ao ingresso de pessoas com deficiências na classe do ensino regular, houve o avanço de 43.923 alunos em 1998 para 325.316 em 2006, o que traduz um crescimento de $640 \%$. Abaixo os dados deste crescimento:

Gráfico 1 - Evolução das matrículas na modalidade da educação es pecial segundo o Censo Escolar de 2006

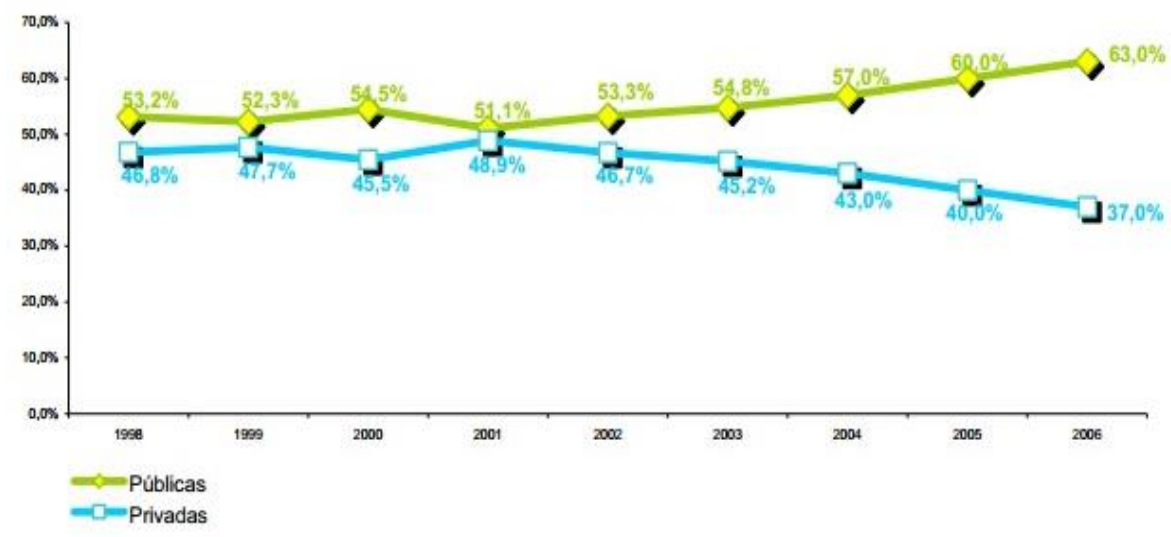

Fonte: BRASIL, 2008.

Se atendo às esferas pública e privada, em 1998 registra-se $179.364(53,2 \%)$ alunos matriculados ne rede pública e 157.962 (46,8\%) alunos matriculados na rede particular, principalmente em instituições especializadas filantrópicas. Com as ações voltadas para a consolidação da educação inclusiva, registrou-se em 2006, 441.155 (63\%) alunos matriculados na escola pública, o que corresponde a um crescimento de 146\%, conforme confirma o gráfico a seguir:

42 PORTAL DA EDUCAÇÃO. Diagnóstico da Educação Especial. 2013. Disponível em: https://www.portaleducacao.com.br/pedagogia/artigos/43414/diagnostico-da-educacao-especial. Acesso em: 24.02.2013. 
Gráfico 2 - Matrículas nas es feras públicas e privadas segundo o Censo Escolar de 2006.

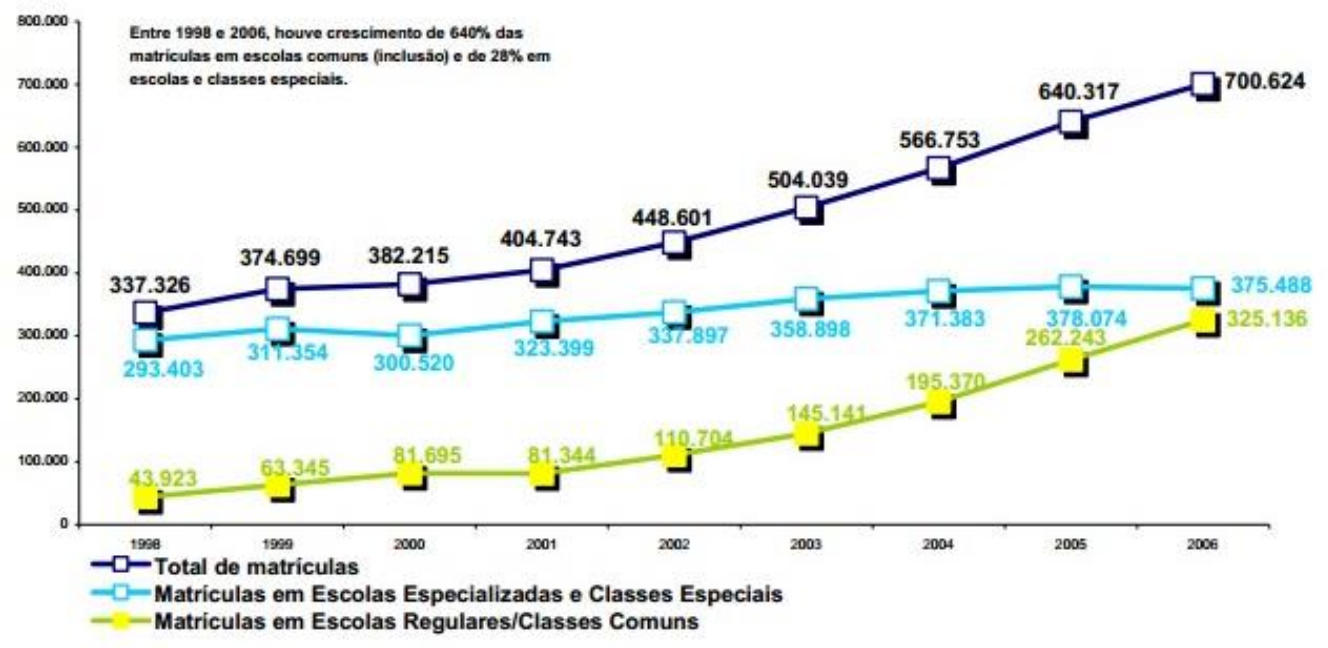

Fonte: BRASIL, 2008.

Segue ainda apontando os dados referentes às matriculas registradas nas diferentes modalidades de ensino, do crescimento no número de escolas com matricula na modalidade da educação especial, da acessibilidade arquitetônica nos prédios escolares, sobre a formação inicial dos professores que atuam na educação especial e também sobre o ensino superior que diz o seguinte:

O Censo da Educação Especial na educação superior registra que, entre 2003 e 2005, o número de alunos passou de 5.078 para 11.999 alunos, representando um crescimento de $136 \%$. A evolução das ações referentes à educação especial nos últimos anos é expressa no crescimento de $81 \%$ do número de municípios com matrículas, que em 1998 registra 2.738 municípios (49,7\%) e, em 2006 alcança 4.953 municípios $(89 \%) .{ }^{43}$

Continua definindo os alunos que devem ser público-alvo da educação especial e conclui estabelecendo as diretrizes da política nacional de educação especial na perspectiva da educação inclusiva. Nesta última, explicita que:

A educação especial é uma modalidade de ensino que perpassa todos os níveis, etapas e modalidades, realiza o atendimento educacional especializado, disponibiliza

${ }^{43}$ PORTAL DA EDUCAÇÃO, 2013, op. cit. 
os recursos e serviços e orienta quanto a sua utilização no processo de ensino e aprendizagem nas turmas comuns do ensino regular. ${ }^{44}$

Faz direcionamentos pertinentes ao atendimento educacional especializado, as atividades que deverão ser trabalhadas no AEE, aspectos da educação de jovens e adultos, educação profissional, educação indígena, do campo e quilombola. Promoção de acesso ao ensino superior e dos alunos surdos nas escolas comuns - educação bilíngue -, a avaliação pedagógica, a formação do professor e também a organização e condições de acesso por parte do sistema de ensino.

\subsubsection{Plano Nacional de Educação (PNE)}

Sancionado em 25 de junho de 2014, a Lei n. 13.005/2014 ${ }^{45}$, esta lei que instituiu o novo do Plano Nacional de Educação (PNE), veio por comando da Constituição Federal de 1988, através de seu art.214, e orienta-se esse plano por vários feixes de diretrizes que devem ser observados obrigatoriamente pelo nosso sistema educacional, com vigência de dez anos, até 2024.

O objetivo primordial desse plano é a articulação do sistema nacional de educação em regime de colaboração e a definição de diretrizes, objetivos, metas e estratégias, voltados para garantir a manutenção e desenvolvimento do ensino em seus diversos níveis, etapas e modalidades, por meio de ações integradas dos poderes públicos das diferentes esferas federativas que conduzam principalmente a: erradicação do analfabetismo, universalização do atendimento escolar; melhoria da qualidade de ensino, formação para o trabalho; promoção humanística, científica e tecnológica do País e estabelecimento de meta de aplicação de recursos públicos em educação como proporção do produto interno bruto. Este plano é um rol de compromissos do estado no campo da educação e deve constituir prioridade substantiva das políticas articuladas dos entes federados, sob o acompanhamento presente e permanente da sociedade, inclusive pelas organizações e conselhos organizados.

\footnotetext{
${ }^{44}$ PORTAL DA EDUCAÇÃO, 2013,

45 BRASIL. Decretos e Leis. Lei no 13.005 , de 25 de junho de 2014. Aprova o Plano Nacional de Educação PNE e dá outras providências. Diário Oficial [da] República Federativa do Brasil. Brasília, 26 de junho de 2014. Disponível em: https://www.planalto.gov.br/ccivil_03/_ato2011-2014/2014/lei/113005.htm. Acesso em: 28.08.2014.
} 
Segundo Moaci Alves Carneiro ${ }^{46}$, o PNE não é um plano de metas, tampouco um plano de obtenção de recursos de um corpo legal de alinhamento de prestação de serviços educacionais, sustentado por uma formulação engenhosa para direcionar, sob conveniência circunstanciais, a atração e a aplicação de recursos financeiros. O PNE na verdade viabilizaria a aproximação e atuação em parceria da União, Estados, Municípios e Distrito Federal para garantir um pacto por uma educação nacional de qualidade e universal, construindo um sistema nacional de educação (SNE).

O citado Moaci Alves Carneiro ${ }^{47}$, diz sobre o PNE:

Embora em pleno vigor, faz (O PNE) o mesmo percurso da educação brasileira: um passo à frente, um passo atrás. Caminha sob um calculado descompasso. De qualquer sorte é muito importante que haja um Plano Nacional de Educação, mesmo que não caminhemos com firmeza, há uma direção, o que não apenas posiciona a sociedade, mas também motiva a todos aqueles que sabem que, pra chegar, é necessário dar o primeiro passo.

Em relação ao atendimento as crianças com deficiência intelectual, o PNE na denominada Meta 4 tem, como intenção, universalizar, para a população de quatro a dezessete anos com deficiência, transtornos globais do desenvolvimento e altas habilidades ou superdotação, o acesso à educação básica e ao atendimento educacional especializado, preferencialmente na rede regular de ensino, com a garantia de sistema educacional inclusivo, de salas de recursos multifuncionais, classes, escolas ou serviços especializados, públicos ou conveniados.

Nessa Meta 4 o PNE cria algumas estratégias para alcançar o objetivo geral. Entre as que nós interessamos para este estudo destacamos:

4.1. contabilizar, para fins do repasse do Fundo de Manutenção e Desenvolvimento da Educação Básica e de Valorização dos Profissionais da Educação (Fundeb), as matrículas dos(as) estudantes da educação regular da rede pública que recebam atendimento educacional especializado complementar e suplementar, sem prejuízo do cômputo dessas matrículas na educação básica regular, e as matrículas efetivadas, conforme o censo escolar mais atualizado, na educação especial oferecida em instituições comunitárias, confessionais ou filantrópicas sem fins lucrativos, conveniadas com o poder público e com atuação exclusiva na modalidade, nos termos da Lei $n^{\circ} 11.494$, de 20 de junho de 2007;

4.2. promover, no prazo de vigência deste PNE, a universalização do atendimento escolar à demanda manifesta pelas famílias de crianças de zero a três anos com deficiência, transtornos globais do desenvolvimento e altas habilidades ou

${ }^{46}$ CARNEIRO, Moaci Alves. PNE Fios e desafios do plano nacional de educação. Brasília: Ed. Direcional, 2015.

${ }^{47}$ Id., ibid., p.16. 
superdotação, observado o que dispõe a Lei $n^{\circ}$ 9.394, de 20 de dezembro de 1996, que estabelece as diretrizes e bases da educação nacional;

4.3. implantar, ao longo deste PNE, salas de recursos multifuncionais e fomentar a formação continuada de professores e professoras para o atendimento educacional especializado nas escolas urbanas, do campo, indígenas e de comunidades quilombolas;

4.4. garantir atendimento educacional especializado em salas de recursos multifuncionais, classes, escolas ou serviços especializados, públicos ou conveniados, nas formas complementar e suplementar, a todos(as) alunos(as) com deficiência, transtornos globais do desenvolvimento e altas habilidades ou superdotação, matriculados na rede pública de educação básica, conforme necessidade identificada por meio de avaliação, ouvidos a família e o alun o;

4.5. estimular a criação de centros multidisciplinares de apoio, pesquis a e assessoria, articulados com instituições acadêmicas e integrados por profissionais das áreas de saúde, assistência social, pedagogia e psicologia, para apoiar o trabalho dos(as) professores da educação básica com os(as) alunos(as) com deficiência, transtornos globais do desenvolvimento e altas habilidades ou superdotação;

4.6. manter e ampliar programas suplementares que promovam a acessibilidade nas instituições públicas, para garantir o acesso e a permanência dos(as) alunos(as) com deficiência por meio da adequação arquitetônica, da oferta de transporte acessívele da disponibilização de material didático próprio e de recursos de tecnologia assistiva, assegurando, ainda, no contexto escolar, em todas as etapas, níveis e modalidades de ensino, a identificação dos(as) alunos(as) com altas habilidades ou superdotação;

$[\ldots]$

4.8. garantir a oferta de educação inclusiva, vedada a exclusão do ensino regular sob alegação de deficiência e promovida a articulação pedagógica entre o ensino regular e o atendimento educacional especializado;

$[\ldots]$

4.12. promover a articulação intersetorial entre órgãos e políticas públicas de saúde, assistência social e direitos humanos, em parceria com as famílias, com o fim de desenvolver modelos de atendimento voltados à continuidade do atendimento escolar, na educação de jovens e adultos, das pessoas com deficiência e transtornos globais do desenvolvimento com idade superior à faixa etária de escolarização obrigatória, de forma a as segurar a atenção integral ao longo da vida;

4.13. apoiar a ampliação das equipes de profissionais da educação para atender à demanda do processo de escolarização dos(das) estudantes comdeficiência.

O importante a frisar nesta meta relacionada aos alunos com deficiência, e que pode servir as demais metas, que para ser realizada em sua plenitude é necessária uma forte articulação interfederativa, até porque a maior parte das diretrizes e estratégias dela situa-se no âmbito dos estados e municípios (conforme prevê o art.10 e 11 da LDBEN). No entanto, no dizer de Moaci Alves Carneiro, sua natureza de responsabilidade pública impõe solução de natureza republicana. Neste sentido, requer uma atuação mais presente e operacional do Governo Federal: menos contemplativa e de discurso, e mais indutora no campo da assistência técnica e do apoio financeiro. 


\subsubsection{Plano Viver Sem Limites}

O Plano Nacional dos Direitos da Pessoa com Deficiência - Viver Sem Limite, é lançado por meio do Decreto $\mathrm{n}^{\mathrm{o}} 7.612$ de 17 de novembro de 2011, reafirmando o compromisso do Brasil com as prerrogativas do Convenção sobre os Direitos da Pessoa com Deficiência, da ONU e traz como proposta que o Governo Federal, Estados, Distrito Federal e municípios oportunize que a Convenção se consolide na sociedade através da articulação de politicas governamentais de acesso à educação, inclusão social, atenção à saúde e acessibilidade.

O Plano foi elaborado com a participação de mais de 15 ministérios e do Conselho Nacional dos Direitos da Pessoa com Deficiência (CONADE), trazendo contribuições da sociedade civil. O Plano Viver sem Limite envolve todos os entes federados e prevê um investimento total no valor de R 7,6 bilhões até 2014.

Esta ação apresenta em seu corpo os tópicos Acesso à educação; Inclusão Social; Acessibilidade e Atenção à Saúde. Para nos atentarmos para o tema que nos compete verificase que na seção Acesso à educação estão incluídos como subtópicos:

\footnotetext{
Implantação das Salas de Recursos Multifuncionais; Escola Acessível; Transporte Escolar Acessível - Programa Caminho da Escola; Pronatec; Acessibilidade na Educação Superior - Incluir; Educação Bilíngue - Formação de professores e tradutores-intérpretes em Língua Brasileira de Sinais (LIBRAS); BPC na Escola. ${ }^{48}$
}

No Plano é explicado informações detalhadas sobre as ações propostas para cada subtópico acima mencionado. As ações buscam basicamente comtemplar a implantação de Salas de Recursos Multifuncionais (SRM), a promoção de acessibilidade arquitetônica nas escolas, a formação de professores para realização do Atendimento Educacional Especializado (AEE) e a aquisição de ônibus escolares acessíveis. Nota-se, assim, que as salas multifuncionais junto com a formação dos docentes são requisitos fundamentais para o apoio e inclusão educacional dos alunos com deficiência no AEE.

\footnotetext{
48 BRASIL. Decretos e Leis. Decreto $\mathrm{n}^{\mathrm{o}}$ 7.612, de 17 de novembro de 2011. Institui o Plano Nacional dos Direitos da Pessoa com Deficiência - Plano Viver sem Limite. Diário Oficial [da] República Federativa do Brasil. Brasília, 18 de novembro de 2011. Disponível em: http://www.planalto.gov.br/CCIVIL_03/_Ato20112014/2011/Decreto/D7612.htm. Acesso em: 28.08.2014.
} 


\subsubsection{Plano Existir}

No Pará, seguindo o Plano Viver Sem Limite, temos o Plano Estadual de Ações Integradas à Pessoa com Deficiência - "Existir", que foi lançado em 23 de outubro de 2012, pelo Governo do Estado do Pará, através da Secretaria Especial de Proteção e Desenvolvimento Social (SEEPDS) que hoje é denominada de Secretaria Estadual de Assistência Social, Trabalho e Renda (SEASTER). Este plano estadual objetiva "promover ações integradas entre as diversas políticas públicas visando à garantia da cidadania, inclusão e maior autonomia das pessoas com deficiência, no Estado do Pará"49. Segundo a apresentação do Plano:

O Estado do Pará, tem população de 7.443.904 habitantes (IBGE - Estimativa Populacional 2010), distribuída em 144 municípios, é o $8^{\circ}$ Estado mais populoso do Brasil e o maior em número de habitantes da Região Norte.

Segundo o Censo 2010, 1.791 .299 pessoas apresentam algum tipo de deficiência no Estado, equivalente a $24 \%$ da população. Considerando que cada família da pessoa com deficiência é composta, em média, por 3 pessoas, calcula-se que mais $72 \%$ da população paraense encontra-se indiretamente envolvida com a questão da deficiência. ${ }^{50}$

Os dados estatísticos não deixam maiores dúvidas de que um Estado de grande porte e com uma quantidade tão elevada de pessoas com deficiência necessita de planos e ações urgentes e abrangentes no que tange a busca pela efetivação dos direitos das pessoas com deficiência. O Plano Existir perpassa as suas ações sustentando-se em quatro eixos, em conformidade com o Plano Nacional Viver Sem Limite. São eles: a) Acesso à Educação; b) Atenção à Saúde; c) Inclusão Social; d) Acessibilidade. ${ }^{51}$

Compete ao tópico 6.1. Acesso à Educação, que possui como órgão executor a Secretaria de Estado de Educação (SEDUC), normatizar as medidas que serão tomadas a partir das ações que esse eixo propõe para a educação, promovendo um conjunto de programas/projetos/atividades que se articulam para constituir o Atendimento Educacional Especializado e a Acessibilidade aos alunos com deficiência para a educação inclusiva. Específica ainda a finalidade dos quatro sub-tópicos existentes, que visam desenvolver os seguintes programas e serviços:

\footnotetext{
49 BRASIL, 2011, op cit.

50 Id., ibid.

51 Id., ibid.
} 
6.1.1 Programa de Implantação de Salas de Recursos Multifuncionais;

6.1.2 Programa Escola Acessivel;

6.1.3 Formação Continuada de Profissionais das escolas da Rede Estadual de Ensino para a Educação Inclusiva;

6.1.4 Assessoramento e Monitoramento nas Unidades Escolares, Unidades Especializadas e Instituições Conveniadas para a Garantia do Atendimento Educacional Especializado (AEE);

6.1.5 Atendimento Educacional Especializado/AEE. ${ }^{52}$

Em cada programa acima mencionado, ficam apresentadas ações que serão tomadas a fim de tornar concreto o objetivo que o plano propõe, pois dentre as XII diretrizes que o plano apresenta, a diretriz de número I aparece como "a garantia de um sistema educacional inclusivo", o que deixa evidente a responsabilidade no setor educacional pelo Estado do Pará.

2.3.6. Resolução Estadual no 001 de 05 de Janeiro de 2010 do Conselho Estadual de Educação do Pará.

Faz-se necessário aqui melhor discorrer sobre a Resolução Estadual no 001 de 05 de Janeiro de 2010, que dispõe sobre a regulamentação e a consolidação das normas estaduais e nacionais aplicáveis à Educação Básica no Sistema de Ensino do Pará. A mesma é promulgada com o aval do presidente do Conselho Estadual de Educação, em consonância com o disposto no Art. 211 da Constituição Federal e Arts. $8^{\circ}$ e $10^{\circ}$ da Lei de Diretrizes e Bases da Educação Nacional - LDB n. 9.394, de 20 de dezembro de 1996 e de acordo com Reuniões Plenárias realizadas em 15 e 17 de dezembro de 2009 com aprovação do Anteprojeto de Resolução 003/2009 CEE/PA.

A ênfase principal desta resolução (para esta produção) deve ser dada ao seu capítulo VII intitulado Da Educação Especial. É redigido no art. 80 que:

Entende-se por educação especial, para os efeitos desta Resolução, a modalidade de educação escolar, oferecida preferencialmente na rede regular de ensino, na modalidade de educação inclusiva, para educandos com necessidades especiais, transtornos globais do desenvolvimento ou altas habilidades, visando ao exercício pleno de sua cidadania e garantindo metodologias e alternativas de atendimento diferenciadas, de serviços e recursos condizentes com as necessidades de cada aluno. 53

\footnotetext{
52 Id., ibid.,

${ }^{53}$ PARÁ. Conselho Estadual de Cultura. Resolução CEE/PA n. 003, de 17 de dezembro de 2009. Diário Oficial do Estado. Belém, 18 de dezembro de 2009.
} 
Conceituando assim, o que seria definidamente a educação especial. Coloca ainda em seu art. 81 que:

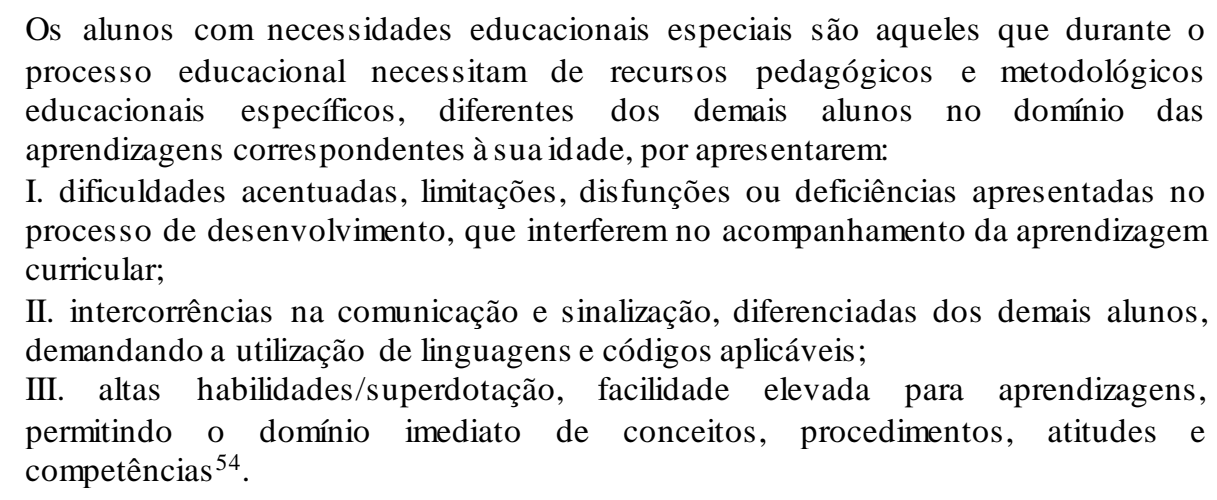

A importância do art. 81 está justamente na definição que faz do público-alvo que deve ser olhado de forma mais sensibilizada perante a comunidade escolar, necessitando de auxilios específicos que saciem as suas necessidades educativas, da melhor forma possível, se atendido sempre a coerência da educação.

O mesmo capítulo prevê ainda outras orientações que abarcam o acesso e o atendimento escolar dos alunos; situações de aprendizagem; a questão do diagnóstico; as responsabilidades cabíveis as instituições escolares do Sistema Estadual de Ensino do Pará que incluem sala de apoio pedagógico específico, professor especializado, sala de recursos multifuncionais, professor itinerante, professores-intérpretes para apoiar alunos-surdos, surdos cegos e cegos, guia intérprete e instrutor mediador para mediar a locomoção e a comunicação do aluno surdo cego; o AEE em classe hospitalar; a frequência escolar; a avaliação do desempenho escolar, entre outras colocações fundamentais para promover uma educação especial de qualidade.

2.3.7. O Plano Estadual de Educação no Pará que norteia a política pública da educação especial e inclusiva nas escolas públicas paraenses.

A lei estadual $n^{\circ}$ 8.186, de 23 de junho de 2015, instituiu no Estado do Pará o Plano Estadual de Educação (PEE) com vigência por dez anos, a contar da publicação desta lei, que se deu no dia 24 de junho de 2015, através de edição extra do Diário Oficial do Estado do Pará, de no 32.913 (documento anexo). Por este plano, o Estado do Pará deu cumprimento ao

\footnotetext{
54 Id., ibid.
} 
disposto no art. $8^{\circ}$ da Lei Federal $n^{\circ} 13.005$, de 24 de junho de 2014, que instituiu o novo Plano Nacional de Educação - PNE, e que obrigou os Estados, o Distrito Federal e os Municípios elaborarem seus correspondentes planos de educação, ou adequar os planos já aprovados em lei, em consonância com as diretrizes, metas e estratégias previstas neste PNE.

Neste PEE o Estado do Pará se compromete a adotar estratégias para alcançar uma educação satisfatória, como melhor articulação das políticas educacionais com as demais políticas sociais, particularmente as culturais; a consideração com as necessidades específicas das populações do campo e das comunidades indígenas e quilombolas, asseguradas a equidade educacional e a diversidade cultural e no caso específico do no nosso estudo; se compromete a garantir atendimento das necessidades específicas na educação especial, assegurado o sistema educacional inclusivo em todos os níveis, etapas e modalidades.

Um dos pontos importantes desse plano estadual são as diretrizes assumidas, que são: erradicação do analfabetismo; universalização do atendimento escolar; superação das desigualdades educacionais, com ênfase na promoção da cidadania e na erradicação de todas as formas de discriminação; melhoria da qualidade da educação; formação para o trabalho e para a cidadania, com ênfase nos valores morais e éticos em que se fundamenta a sociedade; promoção do princípio da gestão democrática da educação pública; promoção humanística, científica, cultural e tecnológica do Estado; estabelecimento de meta de aplicação de recursos públicos em educação como proporção do Produto Interno Bruto (PIB), que assegure atendimento às necessidades de expansão, com padrão de qualidade e equidade; valorização dos profissionais da educação; e promoção dos princípios do respeito aos direitos humanos, à diversidade e à sustentabilidade socioambiental.

No Art. $3^{\circ}$ do PEE diz que sua execução e o cumprimento de suas metas serão objetos de monitoramento contínuo anual e com avaliações bienais, devendo ser realizado pelas seguintes instâncias:

I - Secretaria de Estado de Educação - SEDUC;

II - Conselho Estadual de Educação - CEE;

III - Comissão de Educação, Cultura e Saúde da Assembleia Legislativa do Estado do Pará;

IV - Fórum Estadual de Educação. Obviamente que outras instâncias, como Ministério Público e Defensoria Pública, tendo em vista suas atribuições constitucionais, poderão agir para cumprimento do PEE. ${ }^{55}$

55 PARÁ. Lei n ${ }^{\circ}$ 8.186, de 23 de junho de 2015. Aprova o Plano Estadual de Educação - PEE e dá outras providências. Diário Oficial do Estado. Belém, 24 de junho de 2015 . Disponível em: http://fne.mec.gov.br/images/PEE/PAPEE.pdf. Acesso em: 30.04.2015. 
O Fórum Estadual de Educação (FEE), instituído pelo PEE, é de fundamental importância, pois além de acompanhar e avaliar o conjunto de ações estabelecidas por este Plano Estadual de Educação (PEE), terá a incumbência de coordenar a realização de pelo menos duas Conferências Estaduais de Educação, em articulação com as Conferências Nacionais e Municipais, até o final do decênio.

A lei que instituiu o PEE ainda definiu que o plano plurianual, as diretrizes orçamentárias e os orçamentos anuais do Estado do Pará serão formulados de maneira a assegurar a consignação de dotações orçamentárias compatíveis com as diretrizes, metas e estratégias deste PEE e com os respectivos planos de educação, a fim de viabilizar sua plena execução. Outrossim, dentro do princípio da transparência administrativa, deverá o Estado fazer ampla divulgação do PEE aprovado por esta Lei, assim como dos resultados de seu acompanhamento, com total transparência à sociedade.

Em relação especificamente aos alunos com deficiência intelectual, o anexo da lei que traça as metas para efetivação do PEE apresenta na denominada Meta 4 diagnóstico e metas a serem alcançadas para um atendimento efetivo desse público de alunos. Segundo esse diagnóstico, os números oficiais do Ministério da Educação sobre o atendimento da população de 4 a 17 anos com deficiência no Estado do Pará, em termos quantitativos, apresenta valores aquém da média nacional de atendimento do mesmo público.

Este diagnóstico do PEE considerando os números constantes do site do Observatório do PNE em termos quantitativos, no Estado do Pará a população de 4 a 17 anos que está na escola, 193.040 crianças e adolescentes apresentam dificuldade permanente de visão, audição, limitações motoras ou apresentam deficiência mentalintelectual permanente. E que no ano de 2013, 95,60\% das matriculas de alunos com deficiência concentrou-se em classes comuns.

A análise feita neste PEE revela que o atendimento a pessoas com deficiência na faixa etária de 4 a 17 anos deve, para atendimento da primeira parte da meta 4 ser expandido de modo a absorver mais, aproximadamente, 23.000 crianças e adolescentes com necessidades educacionais especiais que se encontram fora da escola. Verifica-se assim, que ainda é um número considerável de alunos que estão sem frequentar uma escola regular.

Quanto ao atendimento educacional especializado (AEE), segundo dados colhidos junto ao Observatório do PNE, o próprio PEE estima que apenas 10.108 crianças e adolescentes se encontram matriculadas nesse tipo de atendimento, verificando, assim, a necessidade de ampliação significativa desse serviço em prol desse alunado.

Essa análise do PEE ainda registra que em relação às salas de recursos multifuncionais, fundamentais para a suplementação e complementação do ensino aos alunos 
com deficiência intelectual, o Estado do Pará tem que envidar esforços significativos para ampliação dessas instalações, tendo em vista que apenas 6,5\% das escolas do estado possuem tais ambientes educacionais e ainda, apenas 4,3\% dos estabelecimentos mantém o serviço em funcionamento. Essa informação oficial é grave, já que sem esses recursos, não só os alunos, mas os professores, ficam sem condições de dar um atendimento de qualidade ao alunado com deficiência.

Como estratégias (ou metas) para dar melhores condições aos alunos com deficiência, e também aos professores que os atendem nas escolas públicas estaduais, o PEE, na meta 4, assim define estratégias mais direcionadas aos alunos com deficiência intelectual objeto desta pesquisa:

4.1) contabilizar no âmbito de suas competências, para fins do repasse do Fundo de Manutenção e Desenvolvimento da Educação Básica e de Valorização dos Profissionais da Educação - FUNDEB, as matrículas dos (as) estudantes da educação regular da rede pública que recebam atendimento educacional especializado complementar e suplementar, sem prejuízo do cômputo dessas matrículas na educação básica regular, e as matrículas efetivadas, conforme o censo escolar mais atualizado, na educação especial oferecida em instituições comunitárias, confessionais ou filantrópicas sem fins lucrativos, conveniadas como poder público e com atuação exclusiva na modalidade, nos termos da Lei 11.494, de 20 de junho de 2007 ;

4.2) estimular no prazo de vigência deste PEE, a universalização do atendimento escolar à demanda manifesta pelas famílias de crianças de 0 (zero) a 3 (três) anos com deficiência, transtorno global do desenvolvimento e altas habilidades/superdotação observado o que dispõe a Lei no 9.394, de 20 de dezembro de 1996, que estabelece as diretrizes e bases da educação nacional;

4.3) implantar, no âmbito de suas competências, ao longo deste PEE, salas de recursos multifuncionais e fomentar a formação continuada de professores e professoras para o atendimento educacional especializado nas escolas urbanas, do campo, indígenas e de comunidades quilombolas;

4.4) garantir no âmbito de suas competências o atendimento educacional especializado em salas de recursos multifuncionais, classes, escolas ou serviços especializados, públicos ou conveniados, nas formas complementar e suplementar, a todos (as) alunos (as) com deficiência, transtorno global do desenvolvimento e altas habilidades/superdotação, matriculados na rede pública de educação básica, conforme necessidade identificada por meio de avaliação, ouvidos a família e o aluno;

4.5) estimular a criação de centros multidisciplinares de apoio, pesquisa e as ses soria, articulados com instituições acadêmicas e integrados por profissionais das áreas de saúde, assistência social, pedagogia e psicologia, para apoiar o trabalho dos (as) professores da educação básica com os (as)alunos (as) com deficiência, transtorno global do desenvolvimento e altas habilidades/superdotação;

4.6) manter e ampliar, no âmbito de sua competência, programas suplementares que promovam a acessibilidade nas instituições públicas, para garantir o acesso e a permanência dos (as) alunos(as) com deficiência por meio da adequação arquitetônica, da oferta de transporte acessível e da disponibilização de material didático próprio e de recursos de tecnologia assistiva, assegurando, ainda, no contexto escolar, em todas as etapas, níveis e modalidades de ensino, a identificação dos (as) alunos (as) com altas habilidades ou superdotação;

[...]

4.8) garantir, no âmbito de suas competências, a oferta de educação inclusiva, vedada a exclusão do ensino regular sob alegação de deficiência e promovida a 
articulação pedagógica entre o ensino regular e o atendimento educacional especializado;

4.9) fortalecer o acompanhamento e o monitoramento do acesso à escola e ao atendimento educacional especializado, bem como da permanência e do desenvolvimento escolar dos (as)alunos (as) com deficiência, transtorno global do desenvolvimento e altas habilidades/superdotação beneficiários (as) de programas de transferência de renda, juntamente com o combate às situações de discriminação, preconceito e violência, com vistas ao estabelecimento de condições adequadas para o sucesso educacional, em colaboração com as famílias e comos órgãos públicos de as sistência social, saúde e proteção à infância, à adolescência e à juventude;

4.10) fomentar pesquisas voltadas para o desenvolvimento de metodologias, materiais didáticos, equipamentos e recursos de tecnologia assistiva, com vistas à promoção do ensino e da aprendizagem, bem como das condições de acessibilidade dos (as) estudantes com deficiência, transtorno global do desenvolvimento e altas habilidades/superdotação;

4.11) promover o desenvolvimento de pesquisas interdisciplinares para subsidiar a formulação de políticas públicas intersetoriais que atendam as especificidades educacionais de estudantes com deficiência, transtorno global do desenvolvimento e altas habilidades/superdotação que requeiram medidas de atendimento especializado;

4.12) promover a articulação intersetorial entre órgãos e políticas públicas de saúde, assistência social e direitos humanos, em parceria com as famílias, com o fi $\mathrm{m}$ de desenvolver modelos de atendimento voltados à continuidade do atendimento escolar, na educação de jovens e adultos, das pessoas com deficiência transtorno global do desenvolvimento e altas habilidades/superdotação com idade superior à faixa etária de escolarização obrigatória, de forma a assegurar a atenção integral ao longo da vida;

4.13) apoiar a ampliação das equipes de profissionais da educação para atender à demanda do processo de escolarização dos (das) estudantes com deficiência, transtorno global do desenvolvimento e altas habilidades/superdotação, garantindo a oferta de professores (as) do atendimento educacional especializado, profissionais de apoio ou auxiliares, tradutores (as) e intérpretes de Libras, guias-intérpretes para surdo-cegos, professores de Libras, prioritariamente surdos, e professores bilíngues; 4.14) auxiliar o Ministério da Educação, nos órgãos de pesquisa, demografia e estatística competentes, a obtenção de informação detalhada sobre o perfil das pessoas com deficiência, transtorno global do desenvolvimento e altas habilidades/superdotação de 0 (zero) a 17 (dezessete) anos;

4.15) incentivar a inclusão nos cursos de licenciatura e nos demais cursos de formação para profissionais da educação, inclusive em nível de pós-graduação, observado o disposto no caput do art. 207 da Constituição Federal, dos referenciais teóricos, das teorias de aprendizagem e dos processos de ensino-aprendizagem relacionados ao atendimento educacional de alunos com deficiência, transtorno global do desenvolvimento e altas habilidades/superdotação;

4.16) promover parcerias com instituições comunitárias, confessionais ou filantrópicas sem fins lucrativos, conveniadas com o poder público, visando a ampliar as condições de apoio ao atendimento escolar integral das pessoas com deficiência, transtorno global do desenvolvimento e altas habilidades/superdotação matriculadas nas redes públicas de ensino;

4.17) promover parcerias com instituições comunitárias, confessionais ou filantrópicas sem fins lucrativos, conveniadas com o poder público, visando a ampliar a oferta de formação continuada e a produção de material didático acessível, as sim como os serviços de acessibilidade necessários ao pleno acesso, participação e aprendizagem dos estudantes com deficiência, transtorno global do desenvolvimento e altas habilidades/superdotação matriculados na rede pública de ensino;

4.18) promover parcerias com instituições comunitárias, confessionais ou filantrópicas sem fins lucrativos, conveniadas com o poder público, a fi $\mathrm{m}$ de favorecer a participação das famílias e da sociedade na construção do sistema educacional inclusivo.

4.19) estabelecer que até o quarto ano de vigência deste PEE todos os prédios escolares públicos e privados estejam adaptados de acordo com o padrão de 
infraestrutura normatizado, de modo a atender aos alunos com deficiências, transtorno global do desenvolvimento e altas habilidades/superdotação e permitir livre e fácil locomoção;

4.20) implantar tecnologias assistivas para o atendimento de todos os estudantes com deficiências e altas habilidades, conforme art. 276 da Constituição do Estado do Pará;

4.21) implementar e implantar equipes de professores itinerantes especializados nas escolas públicas para atendimento dos alunos com deficiências e transtorno global do desenvolvimento e altas habilidades/superdotação;

4.22) criar Centros de Atendimento Educacional especializados para todos os alunos com deficiência e altas habilidades, criar núcleo de condutas típicas/ autismo, lapes, NAAHS, dislexia, com acolhimento, formação e profissionalização;

4.23) garantir o atendimento escolar hospitalar e/ou domiciliar para alunos em tratamento de saúde da Educação Básica, matriculados ou não no Sistema de Ensino Regular da rede pública ou privada, incluindo as casas de apoio, casas de passagem, casa-lar e outras estruturas de apoio da sociedade;

4.24) as segurar que o atendimento escolar hospitalar e/ou domiciliar seja realizado preferencialmente por profissionais da educação do quadro efetivo da rede regular de ensino da Secretaria de Estado de Educação;

4.25) ampliar o serviço de atendimento escolar hospitalar, incluindo as casas de apoio, para todos os Hospitais Regionais do Estado do Pará, até o término da vigência deste Plano;

4.26) fomentar ações compartilhadas e integradas entre os órgãos responsáveis pelos Sistemas de Ensino e Saúde;

4.27) assegurar, no âmbito de suas competências, a Formação Continuada dos profissionais da educação, que atuam nas classes hospitalares e atendimento domiciliar.

4.28) assegurar que o projeto pedagógico das escolas da rede pública e privada estabeleça as orientações e ações para o atendimento dos alunos com deficiências e altas habilidades;

4.29) divulgar experiências educativas exitosas voltadas aos alunos com deficiências, transtorno global do desenvolvimento e altas habilidades/superdotação; 4.31) implantar ou implementar, em regime de colaboração entre os entes, Centros e Núcleos de Atendimento Educacional Especializado para todos os alunos com deficiência, transtorno global do desenvolvimento e altas habilidades/superdotação com recursos didático pedagógicos, mobiliários, equipamentos específicos e profissionais com habilitação específica que atendam às necessidades educacionais dos estudantes da Educação Especial em todos os municípios do Es tado do Pará. ${ }^{56}$

Estas estratégias inseridas no PEE responsabilizam o Estado do Pará para que ofereça obrigatoriamente estas estruturas e serviços nas escolas públicas estaduais, e por consequência na Escola Estadual Marta da Conceição, para a inclusão educacional de fato aos alunos com Deficiência Intelectual (DI) matriculados neste estabelecimento e que necessitam de apoios, serviços educacionais especiais e estrutura física acessível e de pessoal capacitados, para um aprendizado e convivência na escola com qualidade e dignidade.

${ }^{56}$ PARÁ, 2015, op cit. 


\subsubsection{Estatuto da Pessoa com Deficiência - Lei 13.145/2016.}

Grandes esperanças recaem sobre as determinações normativas acerca de uma política pública inclusiva a pessoa com deficiência. Não é diferente em relação ao Estatuto da Pessoa com Deficiência. O fato de o Estado legalmente adotá-las, se, por um lado, parece demonstrar o cuidado institucional para com as necessidades especiais dessas pessoas com impedimentos físicos, sensoriais, mentais e intelectuais, por outro, também requer uma análise mais profunda e cuidadosa da forma como essa política tem podido encontrar aplicação. Tentaremos fazer essa análise aqui, ao lado de cada inovação legislativa. Não basta, é claro, a adoção formal de uma nova política de inclusão, é também necessário implementá-la de forma consistente. A consistência de uma política de direitos humanos voltada às pessoas com deficiência só pode ser efetivamente alcançada mediante o constante acompanhamento crítico de sua implementação, junto com a sociedade civil organizada, através de seus conselhos e entidades representativas, pois só assim os problemas de percurso podem ser identificados e, com isso, buscar-se tratá-los da forma adequada.

A lei n. 13.146/2015 - Estatuto da Pessoa com Deficiência ${ }^{57}$, além de trazer novos institutos jurídicos relativos à concepção de deficiência, capacidade legal, avaliação psicossocial e acessibilidade, promoveu ainda alterações em diversas normas nacionais em suas disposições finais e transitórias, como no Código Civil, Código de Defesa do Consumidor, Lei de Improbidade Administrativa e Consolidação das Leis Trabalho (CLT), como visto acima.

Seguindo a intenção precípua de efetivar muitos princípios e regras trazidas pela Convenção sobre os Direitos das Pessoas com Deficiência, o Estatuto procura fazer um giro linguístico e conceitual ao adotar o modelo biopsicossocial de deficiência, ao direcionar que os impedimentos físicos, sensoriais, mentais e intelectuais não produzem obstáculos por si só, e sim que estas barreiras que impedem o exercício de direitos são produzidos socialmente, sendo fundamental estratégias políticas, jurídicas e sociais que excluam esses obstáculos e discriminações negativas permitindo aos deficientes demonstrar suas capacidades e usufruir de autonomia e independência para uma real inclusão social.

\footnotetext{
57 BRASIL. Decretos e Leis. Lei no 13.146, de 6 de julho de 2015. Institui a Lei Brasileira de Inclusão da Pessoa com Deficiência (Estatuto da Pessoa com Deficiência). Diário Oficial [da] República Federativa do Brasil. Brasília, 07 de julho de 2015. Disponível em: http://www.planalto.gov.br/ccivil_03/_ato20152018/2015/Lei/L13146.htm. Acesso em: 28.08.2015.
} 
Em relação a educação, o art. 27 do Estatuto prescreve que esta deve constituir direito da pessoa com deficiência, assegurando sistema educacional inclusivo em todos os níveis e aprendizado ao longo de toda a vida, de forma a alcançar o máximo desenvolvimento possível de seus talentos e habilidades físicas, sensoriais, intelectuais e sociais, segundo suas características, interesses e necessidades de aprendizagem. Os principais documentos legais anteriores a essa nova lei, relacionados aos direitos das pessoas com necessidades educacionais especiais, tais como a Constituição Federal (art.205 e 208), Lei de Diretrizes e Bases da Educação Nacional de 1996, a Declaração de Salamanca (1994) e a Convenção sobre os Direitos das Pessoas com Deficiência (2008), já abordavam algumas particularidades referentes à inclusão social e escolar desse público.

Segundo essa nova lei, cabe ao Estado e sociedade criarem as condições para que as pessoas com deficiência, principalmente as crianças com impedimentos cognitivos, tenham direito igual às demais de acesso e permanência nas escolas públicas e privadas regulares e, assim, se dê concretude ao seu direito à educação e à cidadania. Para tanto, impõe-se o reconhecimento das suas diferenças específicas que, precisamente com vistas a possibilitar a igualdade, deverá garantir uma política de ensino adequada às suas necessidades educacionais especiais. Apenas essa especificidade de tratamento poderá possibilitar a sua real inclusão. A questão revela a complexidade de que se reveste o direito atual que, ao afirmar direitos universais, não mais pode permanecer inerte às necessidades especiais de determinados grupos de pessoas, e para garantir o acesso dessas pessoas a esses direitos, há que internalizar no próprio direito políticas e estratégias de enfrentamento das condições que os obstam. Para igualarmos em certos aspectos temos que desigualar em outros com vistas a atingir o fim de garantir a inclusão. Somos diversos, e a diversidade exige que examinemos na teoria e na prática os desafios e as possibilidades postulados à educação, com vistas a darmos à igualdade de oportunidades e à inclusão educacional dessas pessoas.

Para isso o referido Estatuto em seu art.28 a 30 estabeleceu diretrizes a serem observadas tanto pelo ensino público, como pelo privado, para atender com qualidade, igualdade de condições e eficácia as necessidades educacionais especiais do alunado com deficiência. Podemos citar algumas importantes, como: aprimoramento dos sistemas educacionais, visando a garantir condições de acesso, permanência, participação e aprendizagem, por meio da oferta de serviços e de recursos de acessibilidade que eliminem as barreiras e promovam a inclusão plena; projeto pedagógico que institucionalize o atendimento educacional especializado; oferta de educação bilíngue, em Língua Brasileira de Sinais (Libras) aos alunos surdos; pesquisas voltadas para o desenvolvimento de novos métodos e 
técnicas pedagógicas; participação dos estudantes com deficiência e de suas famílias nas diversas instâncias de atuação da comunidade escolar; acesso à educação superior e à educação profissional e tecnológica em igualdade de oportunidades e condições com as demais pessoas; acessibilidade para todos os estudantes, trabalhadores da educação e demais integrantes da comunidade escolar às edificações, aos ambientes e às atividades concernentes a todas as modalidades, etapas e níveis de ensino; oferta de profissionais de apoio escolar ao aluno com deficiência que necessite deste profissional; vedada às escolas privadas ou conveniadas cobrança de valores adicionais de qualquer natureza em suas mensalidades, anuidades e matrículas no cumprimento da política da educação inclusiva. 


\subsection{Tendências da educação especial: integração $x$ inclusão}

Formas diferenciadas de fazer acontecer à inserção do aluno com deficiência no ambiente escolar são encontradas durante esse gradativo processo de inclusão da pessoa com deficiência no cenário educacional. Em consonância com todo o histórico legislativo acima apresentado, está a prática apresentada pelos profissionais da área da educação que, buscando firmar o seu compromisso educacional com a sociedade, necessitou adaptar o seu modo de ensinar, visando instituir o processo de desenvolvimento cognitivo de todos os alunos que em sua sala se encontrassem. Dito isso, elucidamos o ponto ao qual queremos chegar: em meio a todo esse processo de adoção de leis, decretos, resoluções, dentre outras medidas normativas, como foi de fato construído o processo de ensino-aprendizagem das pessoas com deficiência dentro do ambiente escolar? Em que medida essa normativa vem sendo implementada? Esta indagação se faz necessária para podermos adentrar um dos debates mais importantes da educação especial, a questão dos diferentes processos de inserção do aluno na escola, os denominados processos de integração e de inclusão.

As diferenças existentes entre esses dois modos de inserir o aluno com deficiência na escola são cruciais para o melhor entendimento do por que adotar hoje o termo inclusão, perpetuando-a como a melhor forma possível de fazer a inserção do aluno acontecer não só dentro da escola, mas na sociedade como um todo.

Em relação ao processo de integração, este historicamente surgiu por volta de 1959, na Dinamarca, onde nesta época as práticas sociais e escolares de segregação passaram a ser questionadas. O país promulgou então o novo Ato Legal que prescrevia como papel da Educação Especial "criar condições de vida para a pessoa retardada mental semelhantes, tanto quanto possível, às condições normais da sociedade em que vive" ${ }^{" 58}$.

Esse momento histórico começou a refletir em outras práticas em diversos países, incluído Canadá e Estados Unidos, e novas experiências foram surgindo, pois o conceito de "excepcional" a designar algo dado e estático foi sendo humanizado, dando lugar à visão do cidadão possuidor de direitos como os demais.

O conceito de integração chega ao Brasil a partir da década de 60 e se opõe ao modelo de segregação, defendendo a ideia de possibilitar às pessoas com deficiência condições de vida as mais normais possíveis, porém cria serviços especiais para estas, e na

\footnotetext{
58 MENDONÇA, Ana Abadia dos Santos. Escolarização de crianças com deficiência intelectual nos anos iniciais do ensino fundamental. 2014. 171 f. Dissertação (mestrado) -Programa de Mestrado em Educação, Universidade de Uberaba, 2014. Orientador: Prof. Dr. Wenceslau Gonçalves Neto.
} 
educação cria escolas, classes e espaços especiais para esse segmento. A este respeito Maria Tereza Mantoan diz que:

\begin{abstract}
Sua noção (da integração) é o princípio de normalização, que não sendo específico da vida escolar, atinge o conjunto de manifestações e atividades humanas e todas as etapas da vida das pessoas, sejam elas afetadas ou não por uma incapacidade, dificuldade ou inadaptação.

O processo de integração ocorre dentro de uma estrutura educacional que oferece ao aluno oportunidade de transitar no sistema educacional - da classe regular ao ensino especial - em todos os seus tipos de atendimento. (...)Nas situações de integração escolar, nem todos os alunos com deficiência cabem nas turmas de ensino regular, pois há uma seleção prévia dos que estão aptos à inserção. ${ }^{59}$
\end{abstract}

Mantoan, ainda nos diz que "O processo de integração se traduz por uma estrutura educacional intitulada sistema de cascata"60 , ou seja, oferecer ao aluno a oportunidade de percorrer as diversas etapas da integração, indo da classe regular ao atendimento no ensino especial, o que traduz uma inserção parcial, pois a cascata prevê serviços segregados, dependendo do nível em que o aluno se encontra para que se possa perceber em qual espaço ele melhor se enquadrará.

Nesta perspectiva integracionista, não são todos os alunos com deficiência que serão considerados aptos a ser incluídos em uma sala regular junto com os alunos ditos "normais", permanecendo ainda uma boa parcela de alunos com deficiência a frequentar as salas especiais, pois a escola só integrará aqueles que não constituam um desafio a sua competência, sendo essa uma das maiores críticas que se faz ao processo de integração. Basicamente, ao invés de a escola se adequar ao aluno com deficiência, é ele que precisará demonstrar a sua aptidão para ser incluído na classe regular. Em tal formato paralelo, a Educação Especial se apresentava como um espaço substitutivo para aqueles que, por algum motivo, não conseguiam acompanhar o ensino regular; era ofertada, na maioria dos casos, em instituições filantrópicas.

Assim, a Educação Especial possui dois momentos: o primeiro, caracterizado pela ação substitutiva/paralela ao ensino regular, destacado acima; o segundo, representado pela sua ação complementar/transversal ao ensino regular. $O$ formato transversal sinaliza a assunção da perspectiva inclusiva. A inclusão questiona as políticas, a forma de organização

\footnotetext{
${ }^{59}$ MANTOAN, Maria Tereza Eglér. Inclusão Escolar: O que é? Por quê? Como Fazer? São Paulo: Moderna, 2003, p. 22-23.

${ }^{60}$ Id., Ibid.,
} 
da educação especial e também o conceito de integração. Esta se baseia em uma forma de inserção escolar sistemática e completa. Para Mantoan, “o vocábulo “integração" é substituído, uma vez que o objetivo da integração escolar é inserir um aluno ou um grupo de alunos que já foram anteriormente excluídos" ${ }^{61}$.

Com o estudo constante para que se consiga alcançar um princípio mais humanizado sobre a forma de incluir a pessoa com deficiência não só na escola, mas no mundo que a cerca, o processo de integração vai aos poucos dando lugar ao que foi chamado de processo de inclusão. Surge então o termo, escola inclusiva que propõe uma organização escolar adequada, que considere as necessidades de todos os alunos, devendo, portanto, ser estruturada para receber a todos. A inclusão, deste modo, visa a inserir o aluno com deficiência desde o começo da sua vida escolar em classes regulares, não permitindo a criação de turmas especiais, a abolir integralmente os serviços segregados.

Segundo Susan e Willian Stainback em 1972 começaram a surgir nos Estados Unidos decisões judiciais que garantiam a inclusão de pessoas com deficiência em escolas regulares federais como no caso Pennsylvania Association for Retarded Children v. Commonwealth of Pennsylvania, em 1972, que garantiu a inserção de crianças e adolescentes com deficiência intelectual em escolas regulares daquele estado americano. Em 1975, por consequência das várias decisões judiciais, os Estados Unidos editou o chamado Ato Federal da Educação para Todas as Crianças com Deficiência, o que ocasionou que em 1976 todos os estados da federação americana criassem programas com subsídios para escola pública receber alunos com deficiência, principalmente crianças com deficiência intelectual ${ }^{62}$.

Porém Susan e Willian Stainback registram que mesmo nos dias de hoje, muitas tentativas legislativas e práticas conservadoras tem argumentado contra o movimento de inclusão na América do Norte, mas que o movimento cresce com números maiores de crianças identificadas com impedimentos físicos, sensoriais e intelectuais matriculados na rede regular ${ }^{63}$.

Esses ares inclusivos vindos do ocidente chegaram até nós, e a partir de práticas inclusivas inovadoras em São Paulo e no Rio de Janeiro na década de 80, e o processo de redemocratização do País e reafirmação dos direitos humanos dos grupos vulneráveis, foi

\footnotetext{
${ }^{61}$ MANTOAN, 1993, op cit,

62 STAINBACK, Susan; STAINBACK, William. Inclusão: um guia para educadores. Porto Alegre: Artmed, 1999.

63 Id., Ibid.
} 
possível inserir este novo paradigma educacional na Constituição Federal de 1988, principalmente nos seus arts. 23, 24, 205 e 208, influindo nas leis infraconstitucionais seguintes até chegar a Convenção e LBI (Estatuto) nos dias atuais.

Para a Mantoan resume os dois processos da seguinte forma:

Resumindo, a integração escolar, cuja metáfora é a cascata, é uma forma condicional de inserção em que vai depender do aluno, ou seja, do nível de sua capacidade de adaptação às opções do sis tema escolar, a sua integração, seja em uma sala regular, uma classe especial, ou mesmo em instituições especializadas. Trata-se de uma alternativa em que quase tudo se mantém, quase nada se questiona do esquema escolar em vigor. Já a inclusão institui a inserção de forma incondicional, radical, uma vez que o objetivo é incluir um aluno ou grupo de alunos que não foram anteriormente excluídos. ${ }^{64}$

Dessa forma, entende-se que a meta da inclusão é não deixar nenhum aluno de fora, devendo o sistema escolar se adaptar às necessidades educacionais de todos os alunos, pois o que deve mudar é a escola e o seu modelo segregador e não os alunos, para que, assim, se alcance no futuro um resultado de uma consciência cada vez mais evoluída, não só na questão da educação, mas também no desenvolvimento do ser humano enquanto pessoa integral.

A professora Scheilla de Castro Abbud Vieira, que também é Especialista em Metodologia do Ensino da Educação Especial da Universidade Estadual do Pará (UEPA) e Mestre em Ciências da Educação pela Universidade Federal do Pará (UFPA), e que atua também como Professora de Unidade Educacional Especializada a alunos com DI em BelémPará, e em Sala de Recursos Multifuncional, respondendo a entrevista semi-estruturada (documentação anexa), ao ser questionada de como compreende o processo de inclusão educacional de alunos com DI atualmente, e quais os avanços e percalços neste processo que observou no seu período de atuação e estudo na área, assim disse:

Compreendo como um processo em desenvolvimento em que, de um lado temos políticas mal formuladas que tentam atender às exigências legais e de outro lado alguns profissionais e familiares que tentam se ajustar a essa situação. Apesar do estabelecimento de diretrizes e normas que visam o processo de inclusão, o que percebo é que, em termos educacionais, os sistemas ainda pensam a inclusão do ponto de vista integracionista e isso é perceptível na discrepância que se encontra entre o número de matrículas efetivadas e o número de alunos que avançam em anos/séries (retenção) ou que avançam sem que tenham desenvolvido as habilidades mínimas exigidas nas normativas vigentes.

Em termos de avanços percebo que, apesar da forma como vem se dando esse processo, a permanência de alunos com DI nas escolas regulares tem possibilitado a esses sujeitos o desenvolvimento de habilidades sociais e cognitivas pela convivência com outros sujeitos sem DI, e que lhes servem de modelos

\footnotetext{
${ }^{64}$ MANTOAN, 1993, op cit, p. 22.
} 
comportamentais por possibilitar outras trocas, outras regras sociais, atitudinais e cognitivas e, de acordo com teóricos sociocognitivistas, os pares com mais habilidades funcionam como mediadores no processo de construção do conhecimento. Percebo também que um número maior de profissionais tem buscado formação a respeito das questões educacionais e legais.

Como percalços, percebo que a falta de estruturação de ações efetivas em nível macro (secretarias de educação) e micro (escolas) tornaram o processo de inclusão mais lento e de difícil compreensão. A desmobilização das classes especiais, ocorrida ainda no final da década de 1990, embora tenha buscado uma organização que garantisse aos alunos com deficiência intelectual, à época jovens/adultos, respostas educativas adequadas, não alcançou os objetivos pretendidos e esses sujeitos, em sua maioria, restaram nas escolas sem avanços acadêmicos que lhes garantisse ingresso em níveis mais elevados de ensino ou mesmo qualificação profissional $^{65}$.

A educação inclusiva é uma política pública gestada a partir dos ditames da Constituição federal de 1988, principalmente a partir dos seus princípios da dignidade da pessoa humana, e da igualdade. E política pública de caráter permanente e essencial às crianças com impedimentos cognitivos.

Educação Especial é uma modalidade da educação ofertada aos estudantes com deficiência e que, durante muito tempo, teve uma configuração paralela ao ensino comum, ou seja, em classes e escolas especializadas. Em tal formato paralelo, a Educação Especial se apresentou como um espaço substitutivo para aqueles que, por algum motivo, não conseguiam acompanhar o ensino regular; era ofertada, na maioria dos casos, em instituições filantrópicas.

Assim, a Educação Especial possui dois momentos: o primeiro, caracterizado pela ação substitutiva/paralela ao ensino regular, destacado acima; o segundo, representado pela sua ação complementar/transversal ao ensino regular. $O$ formato transversal sinaliza a assunção da perspectiva inclusiva.

A concepção de política pública, a partir de Muller e Surel, é definida como um construto social e como um construto de pesquisa, e nesta perspectiva há o entendimento de que uma política não resolve problemas, mas constrói novas interpretações dos problemas. Ao falarmos de política, deixamos claro que este termo, a partir do estudo de Pierre Muller e Ives Surel, cobre, ao mesmo tempo, a esfera da política (polity), a atividade política (politics) e a ação pública (policies). A primeira faz a distinção entre o mundo da política e a sociedade civil, podendo a fronteira entre os dois, sempre fluida, variar segundo os lugares e as épocas; a segunda designa a atividade política em geral (a competição pela obtenção dos cargos políticos, o debate partidário, as diversas formas de mobilização...); a terceira acepção, enfim,

65 VIEIRA, Scheilla de Castro Abbud. Professora de Unidade Educacional Especializada a alunos com DI em Belém-Pará, e em Sala de Recursos Multifuncional. Informações Verbais. Belém, 2015. Entrevista concedida ao autor desta pesquisa. 
designa o processo pelo qual são elaborados e implementados programas de ação pública, isto é, dispositivos político-administrativos coordenados em princípio em torno de objetivos explícitos. Como é a política da educação inclusiva nesta terceira acepção ${ }^{66}$.

Nesta dissertação trabalhamos com a terceira acepção, no sentido de que a Política de Inclusão Educacional fundamentado nos ditames normativos descritos no capítulo anterior e em programas dos entes federativos responsáveis pela sua implementação, necessita ser efetivada em sua totalidade, de maneira transversal em todos os níveis de ensino, e de maneira intersetorial, onde outros setores, como assistência social e saúde, colaboram em parceria com o sistema educacional, dando suporte para a criança com deficiência intelectual possa permanecer na sala de aula regular integralmente.

A pedagoga Maria Tereza Mantoan, indaga: como fazer essa inclusão escolar? Para a autora não estamos caminhando decisivamente na direção da inclusão, pois não adianta admitir o acesso de todos sem garantir o prosseguimento da escolaridade até o nível que cada aluno for capaz de atingir. Não há inclusão somente com a garantia de matrícula do aluno com deficiência numa escola regular ou classe especial. ${ }^{67}$

E continua Mantoan afirmando que a inclusão resulta de sistemas educativos que não são recortados nas modalidades regular e especial, pois ambas se destinam a receber alunos aos quais impomos uma identidade, uma capacidade de aprender, de acordo com suas características pessoais ${ }^{68}$.

Vemos assim que a questão da inclusão educacional estaciona mais na área política do que na questão jurídica. Sua realização depende mais de ações políticas do que normas, as quais direcionam para a inclusão. Assim, falta a implementação integral dessas normas, planos e programas existentes, que contrastam com a prática cotidiana nas escolas, ainda impregnadas de conservadorismo, preconceitos e práticas integracionistas no viés da educação de crianças com deficiência.

Outrossim, as políticas públicas existentes, a partir das normas implementadas pósConstituição de 1988, não nos leva a rediscutir o modelo de escola existente, de muda-la, a partir da rediscussão e inovação de nossos sistemas educacionais em favor de uma educação mais humana e democrática, e que se assuma que as dificuldades de muitos alunos não são

\footnotetext{
${ }^{66}$ MULLER, Pierre; SUREL, Yves. A Análise das Políticas Públicas. Traduzido por: Agemir Bavaresco, Alceu R. Ferraro. Pelotas: Educat, 2002. 156p. (Coleção Desenvolvimento Social 3).

${ }^{67}$ MANTOAN, 2003, op cit.p.55

${ }^{68}$ Id., Ibid.p.55
} 
apenas deles, mas resultam, como diz Mantoan, em grande parte, do modo como o ensino é ministrado e de como a aprendizagem é concebida e avaliada ${ }^{69}$.

A partir de premissas levantadas por Mantoan, para mudar a escola a fim de que ela seja verdadeiramente inclusiva teríamos que atender as seguintes premissas fundamentais:

1. Recriar o modelo educativo escolar, tendo como eixo o ensino para todos: Pois não se pode encaixar um projeto novo, como é o da inclusão, em uma velha matriz de concepção escolar que não reconhece e valoriza as diferenças, a diversidade. É necessário superar o sistema tradicional de ensinar que centra a aprendizagem no aspecto cognitivo do desenvolvimento e que avaliam os alunos, quantificando respostas-padrão. Seus métodos e suas práticas preconizam a exposição oral, a repetição, a memorização, os treinamentos, o livresco, a negação do valor do erro. E estão sempre preparando o aluno para o futuro. A escola inclusiva se distingue por ter um ensino de qualidade, capaz de tratar as disciplinas como meio de conhecer melhor o mundo e as pessoas que nos rodeiam, ter como parcerias as famílias e a comunidade na elaboração e no cumprimento do projeto escolar. A aprendizagem é acentrada, ora sobressaindo o lógico, o intuitivo, o sensorial, ora os aspectos sociale afetivo dos alunos. Nas práticas pedagógicas predominam a experimentação, a criação, a descoberta, a co-autoria do conhecimento. Vale o que os alunos são capazes de aprender hoje e o que podemos oferecer-lhes de melhor para que se desenvolvam em um ambiente rico e verdadeiramente estimulador de suas potencialidades. A escola inclusiva é espaço educativo de construção de personalidades autônomas, críticas, espaços onde crianças e jovens aprendem a ser pessoa, como também afirma Paulo Freire, em sua Pedagogia da Autonomia.

2. Reorganizar as escolas tanto no aspecto pedagógico como administrativo: primeiramente é necessário que a escola tenha um projeto político-pedagógico, onde sejam traçadas as diretrizes gerais da escola com realismo e responsabilidade. Para isso esse projeto deve ser elaborado com autonomia e participação de todos os segmentos que compõe a escola, definindo prioridade de atuação e objetivos, metas, ações, e as necessidades sobre os recursos humanos e materiais que a escola precisa dispor para realizar esse projeto. $\mathrm{Na}$ escola Marta da Conceição, esse projeto não existe, nunca existiu e nem há planejamento a curto prazo para sua gestação, ainda mais considerando que o Conselho Escolar (que tem a participação de direção, professores, alunos, pais e comunidade) não está funcionando há dois anos. E esse conselho é importante para uma gestão administrativa descentralizada que promova maior autonomia pedagógica, administrativa e financeira de recursos materiais e humanos da escola e que procure atender a diversidade do alunado, e principalmente, o alvo de nosso estudo, os alunos com deficiência intelectual.

3. Atender e ensinar a turma toda: sem exceções e exclusões, garantindo aos alunos tempo e liberdade para aprender, bem como o ensino que não segre ga e que reprova a repetência: para ensinar a turma toda parte-se do pressuposto que de que os alunos sabem alguma coisa, de que todo educando pode aprender, mas no tempo e no jeito que lhe é próprio. As dificuldades e limitações de alguns alunos com deficiência intelectual são reconhecidas, mas não conduzem nem restringem o processo de ensino...

4. Formar, aprimorar continuamente e valorizar o professor, para que tenha condições e estímulo para ensinar a turma toda, sem exceções e exclusões. ${ }^{70}$

${ }^{69}$ MANTOAN, 2003, op cit.p.81

${ }^{70}$ Id., Ibid. p.59 a 82 


\subsection{Educação Básica: o ensino fundamental regular público e o aluno com deficiência}

Considerando que os sistemas educacionais da União, Estados, Municípios e Distrito Federal são autônomos, a regulação do Ministério da Educação (MEC) limita-se a diretrizes, princípios e incentivo de cofinanciamento.

Para Fabiana de Felício $^{71}$ o ensino fundamental reconhecidamente a escolaridade mínima aceita socialmente para todos os cidadãos brasileiros e por isso foi definida, constitucionalmente, a obrigatoriedade de frequência nessa etapa, por parte de todas as crianças e jovens, e de sua oferta gratuita pelo poder público, sendo esta de responsabilidade dos estados, de forma compartilhadas com seus municípios, e do Distrito Federal. É nessa etapa, formada por nove anos, que os alunos passam o maior período da educação básica, devendo ingressar com seis anos e concluir por volta dos 14 a 15 anos. Essa etapa é de maior importância, porque esta nela a formação não só intelectual, mas como cidadão do aluno.

Segundo Fabiana Felício, a PNAD/IBGE de 2007, confirmou que entre as crianças que completaram 8 anos entre julho de 2006 e junho de 2007, 88\% foram declarados alfabetizados, o que reflete um importante avanço quando comparados aos $77 \%$ observados dez anos antes ${ }^{72}$.

Com evolução ainda mais expressiva, a região nordeste elevou a taxa de alfabetização em 26 pontos percentuais, no período de dez anos, chegando a $76 \%$ de alfabetizados aos 8 anos de idade em 2007. No entanto, a desigualdade desse indicador entre as regiões brasileiras ainda é preocupante. O Nordeste se mantém como a região de pior resultado, muito aquém das demais. A região Norte, onde se situa a escola pesquisada, vem logo atrás do Nordeste como área ainda precária na qualidade de educação, e consequentemente do atendimento especializado aos alunos com deficiência intelectual. As regiões Sudeste e Sul, por exemplo, já ultrapassaram a marca de $94 \% .{ }^{73}$

Deste modo, as crianças sem estarem plenamente alfabetizadas aos 9 anos, as dificuldades de aprendizagem as acompanham para as séries subsequentes. É o que pode ser verificado nos resultados das avaliações nacionais e internacionais.

\footnotetext{
${ }^{71}$ FELí́CIO, Fabiana. O Ensino fundamental: Desafios desde a alfabetização até a transição para o ensino médio. In: VELOSO, Fernando (org.) et al. Educação Básica no Brasil. Rio de Janeiro: Elsevier, 2009.

72 Id., Ibid., p. 122.

${ }^{73}$ Id. Ibid.,
} 
Com isso, entende-se que, apesar de uma reversão na tendência de queda do desempenho dos estudantes, observada nas últimas edições do SAEB, a qualidade do sistema educacional ainda está muito distante até mesmo da média dos países do Programa Internacional de Avaliação de Estudantes - PISA (454,1 pontos) e, para que o ensino fundamental nacional atinja o padrão de qualidade médio dos países desenvolvidos, será necessário melhorar a uma velocidade maior e manter essa melhora por muitos anos ${ }^{74}$.

Em “A invencível fraqueza do ensino fundamental,, Claudio de Moura Castro ${ }^{75}$ mostra que nosso ensino básico é medíocre comparado com demais países do ocidente e do nosso nível econômico, como México e Argentina, pois já participamos de várias avaliações internacionais, como o International Assesment of Education Progress (IAEP) em 1992, Unesco/Orealc em 1998, e o Program for International Student Achievemente (PISA), e ficamos sempre em último no IAEP e nas últimas colocações nas três edições do PISA de 2000, 2003 e 2006. Segundo o autor referido, juntando esse rendimento internacional com as avaliações do Sistema Nacional de Avaliação da Educação Básica (SAEB) e do Exame Nacional do Ensino Médio (ENEM), detecta-se precoce problemas de alfabetização, pois mais da metade dos alunos testados na quarta série não pode ser considerada como funcionalmente alfabetizada, e essas consequências se alastram para as séries subsequentes. Para o autor o SAEB mostra uma educação básica de qualidade praticamente constante de 1990 a 2008 :

\begin{abstract}
Uma educação muito fraca diante dos padrões esperados [...] O SAEB confirma uma característica marcante e conhecida: as diferenças entre o ensino particular e o público são muito grandes. No médio, a diferença é de 34 pontos no público para 50 no privado (na prova objetiva). Há o fato inelutável de que o capital intelectual das famílias dos alunos das escolas privadas é muito maior [...]. Quando começamos a medir as competências dos alunos, no início dos 90, houve um aumento explosivo na matrícula e pouca preocupação com a qualidade. É até surpreendente que não se observaram quedas mais significativas nos escores, embora mostrem uma educação muito fraca. ${ }^{76}$
\end{abstract}

Então como exigir um atendimento especial aos alunos com deficiência se o sistema como um todo é precário ?

\footnotetext{
${ }^{74}$ SILVA, Isabelle Fiorelli. O sistema nacional de avaliação: características, dispositivos legais e resultados. Est. Aval. Educ., São Paulo, v. 21, n. 47, p. 427-448, set./dez. 2010.

75 CASTRO, C. D. M. A invencível fraqueza do ensino fundamental. In: VELOSO, Fernando et al. (Ed.). Educação básica no Brasil: construindo o país do futuro. Rio de Janeiro: Editora Campus; Elsevier, 2009. p. 157-158.

${ }^{76}$ Id., ibid., p. 157.
} 
A partir das lições de Fernando Veloso, o caminho para uma melhoria da educação pública, e consequentemente do atendimento educacional especial aos alunos com deficiência intelectual, começaria primeiro em usar a avaliação dos resultados de forma sistemática para aperfeiçoar a política educacional. E esse aperfeiçoamento consistiria principalmente em três mecanismos institucionais de incentivos voltados para o aumento da qualidade da educação, como segue:

O primeiro seria a inserção de mecanismos de responsabilização dos atores educacionais pelos resultados. A criação do IDEB e do Plano de Metas do PDE foi um passo importante nessa direção. No entanto, a experiência de sistemas de responsabilização nos Estados Unidos mostra que a divulgação de metas de desempenho pode não ser suficiente para gerar o nível de cobrança necessário a fim de melhorar de forma significativa a qualidade da educação. Um outro meio disso acontecer é a introdução de um sistema mais explícito de recompensas e punições. Existem várias formas disso acontecer, como a criação de bônus para as melhores escolas, que já está sendo adotada em alguns estados, como São Paulo e Pernambuco.

Um segundo mecanismo importante de incentivos é a existência de competição de escolas por recursos públicos. A ideia é que a perda de receita associada à queda do número de alunos matriculados crie incentivos para que as escolas de baixa qualidade melhorem seu desempenho. Existe também possibilidade de que a vinculação pelo FUNDEF da transferência de recursos ao número de alunos matriculados em redes municipais e estaduais tenha um efeito positivo nas taxas de matrícula e na qualidade da educação do ensino fundamental, principalmente em regiões mais pobres, como na ilha de Cotijuba, onde se localiza a escola pesquisada. Nesse sentido, uma possibilidade interessante seria descentralizar ainda mais esse mecanismo, associando a transferência de recursos às escolas ao número de alunos matriculados em cada unidade.

O terceiro requisito para melhoria do sistema seria algum grau de descentralização e autonomia das escolas. A descentralização pode contribuir para elevar o grau de responsabilização, na medida em que as comunidades locais têm um maior incentivo e capacidade de monitoramento dos resultados das escolas ${ }^{77}$.

77 VELOSO, F.et al. (Ed.). Educação básica no Brasil: construindo o país do futuro. Rio de Janeiro: Campus; Elsevier, 2009. p. 157-168. 


\section{A ESCOLA ESTAdUAL MARTA DA CONCEIÇÃO SITUAdA NA ILHA DE COTIJUBA, EM BELÉM NO ESTADO DO PARÁ, E O ENSINO INCLUSIVO DE CRIANÇAS COM DEFICIENCIA INTELECTUAL}

A Escola Estadual de Ensino Fundamental e Médio Marta da Conceição está localizada na Ilha de Cotijuba, e atualmente possui 02 anexos em funcionamento: anexo da Pedra Branca, no outro extremo da ilha de Cotijuba e o anexo de Urubuoca, na ilha em frente de mesmo nome ${ }^{78}$. Cotijuba é uma ilha pertencente ao município de Belém, e possui uma área de cerca de $60 \mathrm{~km}^{2}$ e uma costa com $20 \mathrm{~km}$ de praias. Historicamente a ilha era denominada de "A Colônia Reformatória de Cotijuba", segundo informações locais e do site Wikipédia ${ }^{79}$, a ilha era desertaantes da década de 1930, e então foi criado e construído pelo Governo do Estado do Pará no período de 1930 a 1934, e fundado em 24 de outubro de 1933, um "Educandário" denominado Nogueira de Farias destinado aos denominados na época "pequenos abandonados, pequenos delinquentes, degenerados por índole ou infelicidade que vão parar às vezes nos postos policiais", na verdade, crianças e adolescentes paraenses que eram mandados para esta ilha, excluidos socialmente. Na década de 1960 transformou-se em presídio para adultos condenados por práticas consideradas ilícitas. Na década de 80 foi desativado o presídio, tendo o Estado transformado a ilha em área de preservação ambiental e de turismo ecológico. A ilha é habitadas por ribeirinhos e familias remanescentes da época do presídio. Essa população vive da pesca, agricultura e do turismo.

Foi possível visitar na pesquisa de campo a sede da escola na Ilha de Cotijuba, onde estão estudando a maioria dos alunos com deficiência intelectual (crianças e adolescentes) e o Anexo da ilha de Urubuoca, onde o acesso se dá por barco, em viagem de 45 minutos entre Cotijuba e aquela outra ilha.

As entrevistas deste trabalho foram realizadas em dois momentos, em agosto de 2015 e janeiro e fevereiro de 2016 na escola estadual Marta da Conceição na Ilha de Cotijuba, e em fevereiro de 2016 na Unidade Técnica de Educação Especial (UTEES) localizada em Icoaraci, Distrito do Município de Belém-Pará.

As entrevistas na escola pesquisada ocorreram com a direção da escola, pais de alunos com deficiência intelectual matriculados, professores de classes regulares do ensino

\footnotetext{
78 PARÁ. Secretaria de Estado de Educação. Consultar Escola. 2016. Disponível em: http://www.seduc.pa.gov.br/portal/escola/consulta_matricula/RelatorioMatriculas.php . Aces so em: 23.02.2016.

79 WIKIPÉDIA. Em: https://pt.wikipedia.org/wiki/Ilha_de_Cotijuba . Acesso em: 23.09.2016.
} 
fundamental, principalmente do primeiro ao terceiro ano, e do professor do atendimento em educação especial (AEE) que auxilia os professores e presta apoio aos alunos com deficiência na sala de aula durante o turno regular e no contraturno na suplementação e complementação nos casos de dificuldades dos alunos com necessidades educacionais especiais. Entrevistamos também participante externo, de projeto da UEPA de leitura na escola.

O prédio sede da escola encontrava-se em reforma quando da primeira visita em agosto de 2015 por força de decisão judicial em ação do Ministério Público Estadual que será adiante esmiuçada, e os demais anexos ficam afastados da Ilha de Cotijuba.

A escola possui 07 salas de aula, 01 secretaria e arquivo, 01 sala onde funcionam a direção e coordenação conjuntas, 01 sala de informática, 01 sala de SAPE para alunos (crianças e adolescentes) com necessidades especiais, 03 depósitos, 03 banheiros, 01 copa. Possui ainda um anexo intitulado "casa de professor" que serve de sala de professor e apoio para os docentes que não residem na Ilha de Cotijuba. A casa encontra-se em precárias condições, não possui mobílias adequadas e os poucos eletrodomésticos existentes também são precários.

A escola funciona nos três turnos e oferece à comunidade os níveis de ensino da Educação Infantil, o Ensino Fundamental I e II e, Ensino Médio nas modalidades Regular e EJA. Nos anexos a oferta é de classes multisseriadas, ou seja, a professora ensina vários alunos de anos diferentes ( $1^{\circ}, 2^{\circ}$ e $3^{\circ}$ ano, por exemplo) todos juntos na mesma sala, realizando atividades diferentes conforme o ano cursado pelo aluno. No caso dos alunos com deficiência, isto torna mais difícil sua inclusão educacional, conforme relato da professora Kátia ouvida no anexo de Urubuoca (entrevista anexa):

Faço uma diferença. Geralmente eu trago atividade diferenciada. Olha: hoje eu quero que vocês levem pra casa isso aqui, vai fazer... Aí ensino direitinho. Geralmente quando não dá pra mim fazer dentro da sala de aula naquele momento... Porque eu trabalho com multisserie. É muito difícil né? Trabalhar com multisseriado... Porque você está trabalhando ali com... Além de estar trabalhando com aluno de vários níveis né? Já porque a gente já pega os alunos nas séries... Os anos diferentes né? Já pesou o mesmo... Para mim desenvolver os conteúdos diferenciados, planos de aula diferenciados... Aí eu faço um plano de aula já adaptando... É para cada... Para cada ano entendeu? Que eu faço. Aí eu sinto assim: não tenho mais dificuldade porque já tenho muito tempo de experiência e dá certo como eu trabalho... Da forma como eu faço. Como eu lhe falei ali. Olha: uns estavam escrevendo nome que você viu lá né? 
Montando o nome com material com alfabeto móvel, outro já estava escrevendo textos, formando textos sobre o Dia do Folclore... Textos variados. ${ }^{80}$

Observou-se que a escola funciona com um número de alunos (crianças $\mathrm{e}$ adolescentes) além de sua capacidade, o que foi possível verificar quando se constatou a inconformidade entre o número de alunos (crianças e adolescentes) apresentados pela secretaria da escola e número de alunos (crianças e adolescentes) registrado na base de dados da SEDUC (documento anexos).

A inconformidade foi justificada pela demanda de alunos (crianças e adolescentes) que procura a escola após o fechamento do número de vagas sendo os mesmos encaixados, por autorização da própria SEDUC, no Relatório de Aproveitamento Final.

A escola não está devidamente autorizada e reconhecida pelo Conselho Estadual de Educação. No final do mês de dezembro de 2012 foi protocolado, no citado Conselho, a solicitação de autorização. O diretor não tem conhecimento de que a escola tenha passado por algum processo avaliativo em gestão anterior.

Quadro 1 - Recursos Humanos

\begin{tabular}{|c|c|c|c|c|}
\hline Escolas & $\begin{array}{|lr|}N^{o} \text { de } & \text { Alunos } \\
\text { (crianças } & e \\
\text { adolescentes) } & \end{array}$ & $\begin{array}{l}N^{o} d e \\
\text { Docentes }\end{array}$ & Técnicos & Demais Servidores \\
\hline Anexo Tiradentes & 81 & 03 & \multirow[t]{5}{*}{02} & \multirow{5}{*}{$\begin{array}{l}\text { Secretária }-1 \\
\text { Apoio Adminis trativo }-2 \\
\text { Porteiro }-4 \\
\text { Merendeira - } 2\end{array}$} \\
\hline Anexo Santo Antônio & 31 & 02 & & \\
\hline Anexo Urubuoca & 23 & 02 & & \\
\hline Anexo Pedra Branca & 30 & 01 & & \\
\hline Total & 865 & 33 & & \\
\hline
\end{tabular}

Fonte: PARÁ (2016).

O diretor Pedro Henrique relatou a dificuldade de conseguir professor para ministrar aula na escola em virtude da dificuldade de transporte e distância da mesma. No entanto, afirmou que, em 2012, só houve a falta do professor na disciplina Língua Portuguesa para uma turma do Ensino Médio o que foi "resolvido" no $2^{\circ}$ semestre com a transferência de carga horária da professora de Artes para assumir a disciplina.

Quanto ao número de servidores, o diretor relata que está faltando uma merendeira no anexo, Pedra Branca. Faltam ainda 02 porteiros, pois um vigia foi remanejado para a função de porteiro a fim de atender parcialmente a necessidade da escola. Falta apoio psicológico que seria da Unidade Técnica em Educação Especial de Icoaraci (UTEES). Na entrevista feita com a coordenadora e professora Irene Maciel, da referida UTEES, foi informada que a única

\footnotetext{
${ }^{80}$ SILVA, Kátia Regina Cardoso da Silva Profes sora do anexo Urubuoca da EEEFM Marta da Conceição. Informações Verbais. Belém, 2015. Entrevista concedida ao autor desta pesquisa.
} 
psicóloga está de licença e não houve substituta para a mesma, estando as escolas da área de atuação da UTEEs sem a cobertura desse profissional de psicologia. Os demais servidores estão em número suficiente.

Dos professores existentes, a exceção dos lotados no Ensino Fundamental I, todos os demais possuem nível superior, no entanto, não há programa de formação continuada. $\mathrm{O}$ diretor da escola justificou que não dispõe de recursos para fazer internamente as capacitações necessárias, dessa forma são aproveitadas as raras capacitações oferecidas pela Secretaria de Educação para esse fim. No caso da educação especial, essa capacitação já não ocorre há anos.

O planejamento das atividades escolares é realizado no início do ano letivo. A partir daí os professores desenvolvem suas atividades autonomamente. No surgimento de alguma situação inusitada procuram conversar com a direção e técnicos.

Verificamos, assim, ausência de Projeto Político Pedagógico (PPP) na escola, essencial inclusive para o planejamento do atendimento educacional dos alunos com deficiência intelectual. Esse PPP, está previsto tanto no Plano Nacional de Educação (PNE) como no Plano estadual de Educação (PEE), conforme visto no capítulo anterior. Segundo o diretor Pedro Henrique essa falta também é consequência do não funcionamento do Conselho Escolar, que há mais de três anos não funciona.

A escola pesquisada não possui biblioteca, são utilizados apenas livros didáticos encaminhados pela Secretaria de Educação. Quanto ao laboratório, verificou-se que a escola possui os equipamentos (alguns danificados por falta de uso), contudo, desde 2009, quando os equipamentos chegaram, não houve professor lotado, impedindo o funcionamento do mesmo.

Outro ponto importante da pesquisa foi não ter encontrado sala multifuncional para atendimento aos alunos com deficiência intelectual, apesar de formalmente estar contido esta sala nos registros do MEC. Inclusive encontramos alguns equipamentos fornecidos pelo MEC, como sorobã e o computador, danificados, e sem uso, numa sala de depósito de materiais da escola. Segundo o diretor isso seria resolvido após a reforma física da escola com destinação da referida sala multifuncional e reequipamento da mesma para o atendimento educacional especial dos alunos com deficiência. Registre-se que esta sala multifuncional é fundamental para o apoio na suplementação e complementação do aluno com deficiência intelectual e para o trabalho do professor em educação especial, estando contido no documento da Política Nacional para a Educação Especial na Perspectiva da Educação Inclusiva do MEC, como também tem previsão na Meta 4 tanto no PNE como no PEE para o atendimento educacional especial. 
Quadro 2 - Estrutura Curricular

\begin{tabular}{|c|c|c|c|}
\hline \multirow[t]{6}{*}{ EJA } & Série/Etapas & Disciplinas & Carga Horária Faltante \\
\hline & $3^{\text {a }}$ Etapa - vespertino & Matemática & 2 aulas \\
\hline & \multirow[t]{3}{*}{ 3a Etapa - noturno } & Educação Física & 2 aulas \\
\hline & & Geografia & 1 aula \\
\hline & & Matemática & 2 aulas \\
\hline & 4a Etapa - noturno & Geografia & 1 aula \\
\hline \multirow[t]{4}{*}{ ENSINO MÉDIO } & $1^{\circ}$ ano - noturno & Ecologia & 1 aula \\
\hline & $2^{\circ}$ ano - noturno & Ecologia & 1 aula \\
\hline & & Língua Portuguesa & 1 aula \\
\hline & $3^{\circ}$ ano - noturno & Geografia & 1 aula \\
\hline \multirow[t]{9}{*}{ FUNDAMENTAL II } & $1^{\circ}$ ano - noturno & Ecologia & 1 aula \\
\hline & $2^{\circ}$ ano - noturno & Ecologia & 1 aula \\
\hline & & Língua Portuguesa & 1 aula \\
\hline & $3^{\circ}$ ano - noturno & Geografia & 1 aula \\
\hline & $5^{\text {a }}$ Série $B-$ vespertino & Inglês & 1 aula \\
\hline & $6^{\text {a }}$ Série - matutino & Ciências & 1 aula \\
\hline & & Inglês & 1 aula \\
\hline & $7^{\text {a }}$ Série - vespertino & História & 1 aula \\
\hline & $8^{a}$ Série - matutino & Ciências & 1 aula \\
\hline
\end{tabular}

Fonte: Pesquisa de campo realizada em 2016.

Por meio deste estudo é possível concluir que a escola está trabalhando com número deficitário de aulas para determinadas disciplinas, conforme demonstrado acima, contrariando a própria legislação educacional que prevê o mínimo de carga horária semanal e mensal, bem como o número mínimo de dias letivos a serem cumpridos. Também se verifica que não há regularidade do atendimento educacional especial aos alunos com deficiência intelectual, já que, além da inexistência de sala multifuncional, não existe um planejamento prévio dos professores em educação especial para o atendimento no contraturno para esses alunos. Além disso em muitas ocasiões os familiares não cumprem com o horário estabelecido, ocasionando prejuízo ao acompanhamento dos alunos com deficiência intelectual, conforme depoimento do Professor Batista, do AEE da escola (depoimento anexo).

No quesito calendário escolar verifica-se o não cumprimento dos 200 dias letivos haja vista que a escola iniciou suas aulas no mês de abril e quando da oportunidade da visita a escola estava parada em função das reformas físicas de seu prédio. Os alunos até dezembro de 2015 estavam apenas indo buscar as atividades passadas pelos professores e realizando estas tarefas escolares em casa, retornando essas tarefas para correção dos professores. Segundo o calendário, devido estes problemas, as atividades escolares seriam retomadas em janeiro de 2016 e terminariam março do mesmo ano. Segundo o diretor Pedro Henrique, a alteração do calendário foi autorizada pela Gestora da USE 12 responsável pela gestão escolar daquela área junto à Secretaria Estadual de Educação do Pará. 
A escola conta com número insuficiente, ou inexistente, de equipamentos de apoio ao aprendizado, como por exemplo, TV, DVD, data-show e outros materiais. Não há verba para aquisição de material básico como pincel para quadro magnético e material de expediente de um modo geral. Segundo o diretor, ele próprio, os professores e servidores fazem coletas para comprar material de expediente e de higiene. Este pesquisador inclusive interviu junto a colega Promotora de Icoaraci - Dra. Darlene Dias, para que a SEDUC repassasse verba para estes gastos, o que só foi possível no final de dezembro de 2015 (ver documento do MP anexo).

A prática de esporte na escola também é precária considerando que não há material desportivo suficiente, assim como quadra de esportes ou local apropriado para a atividade. Inclusive existe área semiconstruída da quadra com recursos federais, mas que se encontra parada, com recursos adicionais não recebidos para conclusão devido a irregularidade documental e administrativa da escola e do Conselho Escolar, segundo informações do diretor Pedro Henrique em entrevista anexa.

Em 2015, quando do início da pesquisa, a escola tinha em torno de 545 alunos. E estavam distribuídos no ensino fundamental menor, primeiro ao quinto ano; fundamental maior, do sexto ao nono ano; e o ensino médio. A escola atende assim ao ensino fundamental e médio. No reinício do ano letivo em janeiro de 2016 a escola já estava com 761 alunos matriculados, distribuídos nos turnos da manhã, tarde e noite.

A escola pesquisada passa atualmente por um processo de transformação física e de pessoal, oriunda de algumas aposentadorias de docentes ocorridas ou em processo de ocorrer, e em relação as construções e adaptações físicas ocorridas principalmente por força de decisão judicial da Vara Judicial Cível de Icoaraci provocada por ação civil pública do Ministério Público do Estado do Pará, em processo iniciado por força do Inquérito Civil no 032/2011. , devido o abandono da escola identificado em vistoria judicial realizada em 01.02.2013. Abaixo abrimos um subcapítulo para explicar melhor este aspecto da escola, importante para demonstrar mais essa dificuldade da escola que influencia também para uma inclusão verdadeira dos alunos com deficiência intelectual naquela ilha paraense.

O Diretor da escola Pedro Henrique França dos Santos ouvido em 25 de agosto de 2015 e em nova entrevista em fevereiro de 2016, conforme documentação anexa com a íntegra das oitivas, relata em alguns trechos pinçados abaixo, as resistências encontradas para implementação de uma política inclusiva ao aluno com deficiência intelectual na escola, pois é muito mais fácil a permanência do discurso que exclui, justificado pela falta de preparo dos professores, da dificuldade de aprendizado dos alunos com DI comparados aos demais alunos 
sem deficiência e de que não há plano político pedagógico planejado para esse público especial. Assim hierarquiza-se os alunos, entre aqueles que aprendem, que se escolariza, e aqueles que não aprendem ou não conseguem acompanhar o ritmo da maioria, prejudicando o "planejamento" escolar daquele ano letivo. Se a educação tradicional prevalecer nas práticas da Escola Marta da Conceição vai levar a continuação da discriminação e da exclusão fática dos alunos com deficiência intelectual. Diz o diretor Pedro Henrique em trecho de sua entrevista:

Desde que a gente assumiu esta gestão nosso desafio maior aqui dentro da escola é resgatar esses alunos que a escola perdeu por conta de uma série de situações que a escola vem passando aí desde 2009. E aí nós estamos com essa missão hoje na escola de resgatar todo um trabalho que já vinha sendo feito dentro da escola e que ao longo do tempo se perdeu [...]. O atendimento educacional especializado ele não existia. Era feito um trabalho de itinerância dentro da escola né? Nós tínhamos um profes sor apenas lotado dentro da escola. E aí quando nós as sumimos nós pedimos a Secretaria de Educação para que fossem feitas abertura das turmas do AEE. Que é o Atendimento Educacional Especializado. Que até então a escola não trabalhava dessa forma. E aí nós garantimos um espaço aqui dentro para que fosse feito esse atendimento. Uma vez que também não tinha o espaço para essas crianças serem atendidas. E hoje nós estamos aí com uma média de 27 alunos com Necessidade Educacional Especial. Na verdade a maior demanda é do Ensino Fundamental Menor. Que dá uma média de 17 alunos[...] A grande maioria: Deficiência intelectual. [...] $\mathrm{Na}$ verdade quando nós recebemos a reforma (da escola) já contempla a sala de recurso multifuncional. Não só a sala, mas como a escola toda ela vai atender ao projeto da escola acessível. Então eu acredito que a partir daí a gente consiga garantir esse atendimento de uma forma assim bem... Bem... Mais apropriada para esses alunos.[...] quando eu cheguei aqui nós reunimos com a equipe. Conseguimos trazer mais um professor. Hoje nós temos dois professores que trabalham nesse atendimento (educacional especial). E... Na verdade eles atendem hoje, não só a escola sede, mas também os anexos. Que não eram atendidos anteriormente. São dois anexos. Anexo Pedra Branca, que fica na área do Poção, próximo à Praia do Vai Quem Quer; e o anexo Urubuoca, que é uma outra ilha. Um pouco mais distante da escola sede. [...] Hoje já está com esse olhar né? Que o professor da turma regular ele faça um trabalho em parceria com o professor da sala de recursos. Em sintonia na verdade. É... Antes nós não tínhamos essa relação. Hoje a gente já pensa que esse trabalho ele precisa acontecer de forma com que tanto o professor da sala de recursos, quanto o professor da sala regular, eles consigam dialogar e estabelecer um trabalho de parceria. Para que esse aluno possa ter o resultado que a gente espera. [...]. A própria realidade da ilha no geral é uma comunidade muito carente. Em todos os sentidos. Então quando se fala desse resgate é justamente da escola exercer também a função dela. A função social que ela tem. E ao mesmo tempo dar essa garantia para essa família .Então muitas das vezes o professor ele acaba sendo que um segundo pai para esse aluno. Porque o próprio pai, que muita das vezes não acredita, quando chega na escola esse professor ele motiva, ele dá essa gotinha de esperança que esse aluno muitas das vezes perde lá dentro de casa. Por conta dessas dificuldades também... A questão do acesso à escola que muitas das vezes é... É difícil para esse pai trazer es se filho até a escola né? E muitas das vezes o professor ele intervém nisso. Então aqui é todo um trabalho é... Em conjunto . Escola, família... Para que a gente não... Não perca.[...] E quando você passa a vivenciar isso, e passa a compartilhar essa luta com essa comunidade, você observa que... Que de fato é... Eles depositam uma... Uma esperança muito grande. Porque é... Como você mesmo falou a pouco, é uma porta que se abre. Então a partir do momento em que essa porta se fecha e eu não tenho mais... Não vejo mais possibilidades de a partir daqui crescer, eu vou acreditar em 
quê? Então eu acredito que esse ano, como eu digo, é desafiador por conta de... De... Dessa comunidade se reconhecer, acreditar que é possível através da educação né? Criar essas pontes novamente para que se possabuscarcoisas melhores. Que é o que a grande maioria dos nossos jovens, crianças aqui, lutam: por um es paço no mercado de trabalho, por qualificação, por uma vida melhor. Eu acredito que é isso" ${ }^{81}$.

A escola neste ano de 2016 possui cerca de 25 alunos (crianças e adolescentes) com necessidades educacionais especiais, sendo que 16 desses alunos tem deficiência intelectual. Nessa área da educação especial verificou-se a lotação de 02 docentes, especialistas na área de atendimento educacional especial. Os quinze alunos distribuídos entre os turnos matutino e vespertino atendidos no ensino fundamental estão abaixo relacionados com seus nomes preservados e das respectivas mães, conforme registro da escola pesquisada:

Quadro 3 - Relação dos alunos com DI

\begin{tabular}{|l|l|l|l|}
\hline$N^{\circ}$ & NOME DO ALUNO/A COM DI & NOME DA MÃE & DATA NASC. \\
\hline 1. & J.S.C. & E. J. S. C. & $06 / 07 / 1999$ \\
\hline 2. & J. R.C.A. & N. C. A. & $15 / 10 / 2000$ \\
\hline 3. & L. S. S. & A. S. S. S. & $22 / 02 / 1996$ \\
\hline 4. & R. A. C. & E. A. C. & $06 / 08 / 1990$ \\
\hline 5. & R. S. T. C. & S. M. S. T. & $13 / 08 / 2007$ \\
\hline 6. & S. C. B. & D. C. B. & $20 / 01 / 1994$ \\
\hline 7. & F. F. C. & L. P. F. & $27 / 02 / 2004$ \\
\hline 8. & G. S. N. & S. G. S. & $31 / 03 / 2003$ \\
\hline 9. & J. A. P. L. & M. L. P. L. & $29 / 02 / 1996$ \\
\hline 10. & O. S. C. F. & $25 / 09 / 1985$ \\
\hline 11. & W. L. S. C. & E. S. C. & $26 / 07 / 1996$ \\
\hline 12. & A. A. P. L. & A. A. C; S. & $27 / 11 / 1989$ \\
\hline 13. & A. A. S. & M. L. G. L. & $05 / 03 / 2001$ \\
\hline 14. & F. F. C. & T. F. A. & $11 / 10 / 1996$ \\
\hline 15. & F. F. C. & L. P. F. & $27 / 03 / 1994$ \\
\hline 16. & G; S. N. & L. P. F. & $15 / 02 / 2005$ \\
\hline 17. & I. C. T. & S. G. S. & $21 / 11 / 20008$ \\
\hline
\end{tabular}

Fonte: Pesquisa de Campo realizada em fev. 2016.

O atendimento específico desses alunos com deficiência intelectual é feito a partir de uma avaliação pedagógica que leva em conta as suas necessidades educacionais especiais e outros aspectos observados e levantados pelo professor em educação especial, como das avaliações anexas dos alunos com DI, I. C. T. e G. S. do N., realizados na escola pelo professor em educação especial Batista Moraes dos Santos. São levados em consideração nessa avaliação para o acompanhamento do aluno com deficiência intelectual, principalmente:

${ }^{81}$ SANTOS, Pedro Henrique França dos. Diretor da EEEF Marta da Conceição. Informações Verbais. Belém, 2015. Entrevista concedida ao autor desta pesquisa. 
as características físicas e neurológicas apresentadas ao nascimento; se a criança foi diagnosticada clinicamente, e caso afirmativo, qual o diagnóstico médico com o CID; a estimulação precoce, a instituição que o atendeu e o desenvolvimento motor adquirido; se frequentou a Educação Infantil na escola regular ou em instituição especializada; quais os aspectos emocionais, a relação familiar, principalmente com os pais, e se o aluno exibe dificuldade em socializar-se.

Cabe registrar que nessa avaliação se atenta principalmente em relação ao desenvolvimento, verificando se o aluno percebe e reconhece todos os estímulos auditivos e visuais, e se os estímulos táteis (textura, espessura, temperatura e dor) e sinestésicos apresentam-se preservados. Outro ponto é se a percepção espacial encontra-se adequada, e se o aluno apresenta dificuldades na temporalidade, no que se refere à ordenação e sequência de fatos cotidianos ou narração de histórias, e se também apresenta dificuldades na memória de curto prazo (auditiva e visual), se esquece por exemplo letras de músicas e histórias contadas pelo professor, e se ainda necessita conhecer e ordenar adequadamente sequências de letras e números, e apresenta dificuldade de atenção e concentração.

Após isso o professor faz observações a serem informadas aos professores da classe regular e também para orientar o próprio professor avaliador no atendimento educacional especial do aluno na suplementação e complementação se for necessário.

A grande questão neste aspecto é se as orientações e observações feitas são realizadas efetiva e plenamente pelos professores regulares na sala comum, pois não há um acompanhamento ou monitoramento disto pelos profissionais da educação especial, muito menos pela equipe técnica da Unidade de Educação Especial (UTEES) de Icoaraci, que pouco vai até a escola pesquisada. Pelas entrevistas feitas com os professores regulares, o professor em educação especial, as técnicas da UTEES e principalmente os pais dos alunos Israel e Geison, isto efetivamente não ocorre, causando um prejuízo no rendimento dos alunos com deficiência intelectual, quando não sua evasão da escola.

O professor Batista Moraes dos Santos, professor em educação especial da escola analisada, foi entrevistado na pesquisa, segundo o referido professor falta apoio para capacitação dos professores em educação especial e consequentemente dos professores das salas comuns na escola Marta da Conceição. Em certo trecho da entrevista o mesmo declara: 
espaço né? [...] Tem que haver uma reconstrução né? De tudo que ele deixou pra trás. Olha por exemplo... Né? Ele reconhece os números né? De 0 a 9 , por exemplo... Tem noções de dezena, mas as centenas ele ainda não consegue chegar. Então são essas coisas que não foram trabalhados... É... Com o aluno na sala. Mas isso aí eu não estou culpando professor. Tu estás entendendo? Por que... É... Dizem que... Até virou... Os alunos da classe comum também não aprendem né... Eles não dominam esses conteúdos etc. e tal. Mas... E o professor também... Agente... Agente da Educação Especial... Agente não tem formação né? E os professores da sala regular menos ainda. ${ }^{82}$

Em outro ponto da pesquisa este Pesquisador, dialogando com o referido Prof. Batista, pergunta: Um dos pontos que foram colocados ontem e que estão querendo retomar é a formação. Ela (Coordenadora da UTEES) disse que não tem condições de vir aqui, e vai ver se começa a fazer uma formação lá (em Icoaraci), e chamará os professores daqui (da escola Marta da Conceição). E o Professor Batista responde:

Pois é... Aí só que é bastante complicado né? Porque eles querem que o professor não falte. E para formação o professor tem que se ausentar da sala de aula. Infelizmente é bem complicado... E no ensino...Por exemplo, a partir do sexto ano é bem mais complicado né? Bem mais complicado essa formação...Pela própria estrutura. Tem professores que estão, por exemplo, hoje aqui, amanhã estão em outras escolas... Seria bem mais fácil se ele fosse lotado em uma só escola como os professores do primeiro ano. Que a grande maioria trabalha numa só escola... Né? Então quando você se ausenta de uma escola você não precisa se justificar de diferentes formas e em diferentes setores né? [...] Não tem (o desenvolvimento do aluno com deficiência intelectual). É muito difícil! É por is so que eu te digo que a verdadeira inclusão ela ainda não aconteceu. Eles só estão inseridos na escola, conquistaram um espaço. Um es paço que é de direito. ${ }^{83}$

A escola desenvolve vários projetos extra-classe, alguns em parceria com a Escola Bosque, Universidade Federal do Pará e UEPA. Dentre os projetos desenvolvidos estão: Preservando a Natureza, Garantindo o Futuro das Próximas Gerações; Projeto Para a Leitura Vai-quem-quer; Semana do Meio Ambiente; Projeto Junino; Jogos Internos; Feira Futura e Escola Ativa. . Neste aspecto entrevistamos na ilha de Cotijuba o estudante Felipe Ambé da UEPA, coordenador discente geral do projeto "Para a leitura vai quem quer", que desenvolve e incentiva a leitura entre os alunos da escola pesquisada e outras do entorno da ilha de Cotijuba:

Quem coordena este projeto é a Professora Izilda Cordeiro. É... Ela é mestre da universidade e também desenvolveu a pesquis a dela aqui sobre gestão... Justamente desse educandário. E ela nos desafiou. Ela desafiou a primeira turma que veio para cá

82 SANTOS, Batista Moraes dos, Prof. da EEF Marta da Conceição. Informações Verbais. Belém, 2015. Entrevista concedida ao autor desta pesquisa.

${ }^{83}$ SANTOS Batista, 2015. 
desenvolver o projeto a fazer uma atividade de leitura que pautasse o incentivo à leitura. Uma forma de você incentivar a leitura para as crianças. E esse desafio foi aceito e a primeira ação que foi desenvolvida aqui foi uma atividade de contação de história, uma contação de história via educativa no sentido de sempre ter... Porque a função da contação de histórias é sempre tu ter uma questão moral por trás. Moralizante... Que é para criança fazer essa... Esse... Essa captação.

A questão dos alunos com deficiência perpassa primeiramente pela participação deles nas nossas atividades, ou seja, acontece com uma certa raridade por... Às vezes... Talvez a compreensão dos próprios pais... Ah! Vou levar o meu filho para lá, numa atividade que seja direcionada a crianças ditas normais ou a crianças que não sejam portadores de necessidades especiais... Então já perpassa por essa dificuldade. Então isso dificulta um pouco da gente ter essa... Essa visão da evolução de um determinado... Porque ele aparece em uma ação e na outra já não aparece... Infelizmente nosso projeto vem amadurecendo a ideia de se tornar cada vez mais presente na ilha. Hoje nós fazemos essas ações duas vezes no mês, três vezes no mês... Lá na comunidade. E existe a proposta da gente sair um pouco mais do anexo e também vir mais um pouco para o centro da ilha para desenvolver esse trabalho na escola sede no Marta da Conceição onde nós vamos ter uma outra abordagem.

Em relação aos professores é importante verificarmos os vários graus de consciência sobre a permanência da exclusão na tentativa da inclusão em sala de aula. Os professores e professoras das salas comuns entrevistados tem uma dualidade de postura, como se houvesse duas modalidades de atuação, atividades diferenciadas para os alunos com deficiência e para os alunos sem deficiência, duas formas de tratamento, sem uma metodologia prévia, sem um planejamento pedagógico. Não se verifica uma otimização do processo de aprendizagem por meio dessas atividades oferecidas aos alunos com deficiência intelectual na sala de aula. $\mathrm{O}$ próprio professor justifica esse procedimento ao afirmar que o aluno deficiente intelectual não tem condições de acompanhar os demais. Aqui está presente uma crescente modalização do discurso, fazendo crer que é praticamente impossível a concretização da inclusão educacional. Para os docentes, é sempre muito difícil, é sempre complicado. Sempre tentam fundamentar a premissa que a classe regular não é o local ideal para os alunos com deficiência intelectual. Como se verifica da entrevista anexa da Professora Maria Alba Morais dos Santos, que atende o horário matutino e vespertino da Escola pesquisada, oitiva realizada em 25 de agosto de 2015 em que fala sobre o atendimento ao aluno com deficiência intelectual J. da S. C. (matriculado no $3^{\circ}$. Ano) e as dificuldades encontradas:

Ele tem uma característica bem diferenciada dos outros alunos. E ele apresenta uma série de dificuldades: de memória, aprendizado. Tem outras situações que ele 
apresenta que não são características de normalidade né? E a gente começou a observar e tentou convers ar com os pais. E os pais infelizmente não aceitam este tipo de acompanhamento. Ele é uma criança que precisa de um professor direcionado a ele para acompanhar as atividades [...] Ele é um aluno disperso também [...]. Acho que deveria criar, uma sala assim, de apoio para eles que nem era antes. Para ele ter um acompanhamento lá na sala e aquele professor trabalhar com ele naquela sala. Como ele se socializar numa sala com os ditos normais? [...]. Ah! Porque ele apresenta mais dificuldade, ele é mais lento, ele não consegue acompanhar as disciplinas. Eu acho que o ideal é o acompanhamento primeiro por um professor, para ele saber como ele vai trabalhar com essas duas turmas. Tanto desse dito normal, como esses alunos que é chamado necessitado de educação especial, né? Para depois colocar esses alunos juntos dentro da sala de aula. [...]. Você não pode discriminar um aluno porque ele é especial. Você não pode discriminar esse aluno aqui. Então vamos incluir ele. Todos Juntos! Essa é a dificuldade. Enós não tivemos esse olhar para is so. Não é só colocar o aluno na sala de aula e pronto. Olha o aluno especial! Ele vai estar inserido. Qual o cuidado que tiveram com isso? Não apresentou nenhum cuidado. Coloca-se um aluno especial numa sala que tem trinta alunos ditos normais, né? Não houve esse cuidado. É implantar este sistema? Implantou o aluno, mas olhar, com aquele olhar que deveria ter, não foi olhad o para ele e nem para o professor. Que enfrenta uma barreira. E muito! E eu é que o diga! E eu é que sei a barreira que tenho que enfrentar. Por que. E quando o professor trabalha só com uma turma ainda tem lá seus benefícios. No meu caso que eu tenho seis! Só em um horário. Aí eu tenho que desenvolver tudo e dar conta do recado, porque eu preciso que meu aluno...a minha meta é o meu aluno aprender. Então a gente tem que se desdobrar ${ }^{84}$.

Fazendo um cotejo dos dados levantados e o estudo das professoras Márcia Denise Pletsch e Rosana Glat, corporificado no artigo "A Escolarização de alunos com deficiência intelectual: uma análise da aplicação do Plano de Desenvolvimento Educacional Individualizado", que afirmam que apesar dos avanços científicos e da implementação de políticas públicas na perspectiva da inclusão, as práticas pedagógicas e a cultura escolar que se verifica no dia-a-dia da instituições públicas de ensino não sofreram ressignificação. Os dados coletados nesta pesquisa e na pesquisa das referidas professoras demonstram que não houve mudanças significativas no atendimento escolar e na qualidade dos programas educacionais destinados aos alunos com deficiência intelectual ${ }^{85}$.

Além disso, Pletsch e Glat, em seu estudo, mostram que os professores do ensino comum não assumem, na prática, a responsabilidade didática pelos alunos com deficiência incluídos em suas turmas. E essa situação é mais agravante com os alunos com deficiência intelectual, já que o fantasma da "Educação Especial" continua no discurso dos docentes, no

\footnotetext{
${ }^{84}$ SANTOS, Maria Alba Morais dos, professora da EEEFM Marta Conceição, falando sobre o aluno J. da S. C., aluno da mesma escola que apresenta DI. Informações Verbais. Belém, 2016. Entrevista concedida ao autor desta pesquisa.

85 PLETSCH, Márcia Denise; GLAT, Rosana. A Escolarização de alunos com deficiência intelectual: uma análise da aplicação do Plano de Desenvolvimento Educacional Individualizado. Revista Linhas Críticas: Revista Semestral da Faculdade de Educação da Universidade de Brasília - UNB, v. 18, n 35, p. 200-211, jan./abr. 2012
} 
sentido que estes alunos deveriam estar em classes especiais e com atendimento diferenciado e destacado dos demais alunos. Além de que a concepção de deficiência intelectual nas escolas pesquisadas, ainda é impregnada pelo modelo médico, que reforça as limitações cognitivas dos alunos, restringindo, ou até mesmo impossibilitando, as possibilidades de aprendizagem e desenvolvimento desses discentes ${ }^{86}$.

O aluno com DI G. S. do N., conforme relatório da escola (doc. anexo), apresenta atraso no desenvolvimento mental associado a questões genotípicas, e, ainda segundo esse relatório: a partir de avaliação inicial do aluno, percebeu-se que o mesmo encontra-se com base suficiente para iniciar seu processo de letramento, visto que reconhece todas as letras do alfabeto, já faz junção silábica e lê palavras de estrutura simples. Para tanto, serão desenvolvidas atividades que foquem no desenvolvimento da memória; a relação número quantidade; e leitura e interpretação de diferentes gêneros textuais. Pensamos em atividades que envolvam pintura, recorte e colagem e relação entre início, meio e fim. Leitura de textos com imagens, jogos interativos. Para que tais atividades tenham melhor aproveitamento, pensamos em um atendimento de 01h30min durante dois dias da semana, no contra turno, a serem combinados com o/a responsável do aluno.

A Sra. Silvânia Gomes da Silva, mãe do referido aluno G. S. do N., atualmente com 12 anos, e ainda no terceiro ano do ensino fundamental da escola pesquisada Marta da Conceição, demonstra, através dos trechos abaixo transcritos, em entrevista de 24.08.2015, documentação anexa, as dificuldades de seu filho nos anos letivos anteriores e atual junto aos docentes no estabelecimento público citado:

O meu nome é Silvânia Gomes da Silva. Eu sou a mãe do G. Que estuda aqui já há muito tempo. Desde a idade dele de sete anos ele estuda aqui. Ness a escola. Quando eu vim morar pra cá. Ele estuda aqui. Então o G. ele passou três anos estudando aqui. Só que ele não tinha desenvolvimento nenhum. Porque pela especialidade dele ele enfrentou muitos problemas para estudar aqui. Então ele é as sim uma criança que ele tem uma dificuldade muito grande. Uma aprendizagem né? O aprendizado dele então... Ele é assim... Ele é uma criança inteligente, mas ao mesmo tempo é uma criança muito lenta na aprendizagem dele [...]. Então chegou um dia de eu chegar aqui com o professor e falar com ele que não estava tendo possibilidade de eu mandar o meu filho mais... Vir para cá para o colégio... Por quê? Ele passava... Ele vinha das sete da manhã, saía meio dia... Chegava em casa ele não fazia duas palavras no caderno. Aí eu cheguei a vim fazer reclamação com professor ainda... E ele disse: só que eu não posso ficar empatado com o seu filho. Aí foi que ela falou isso. Né? E disse: eu não posso ficar empatado comele. Por quê? Eu tenho uma sala grande de aluno. Uma classe grande...Então eu não posso ficar. Aí foi que eu disse: se for para ser dessa maneira dele vir só para cá passar o dia... Então para mim não

\footnotetext{
86 Id., Ibid,
} 
vai adiantar. Porque não está tendo desenvolvimento com o meu filho [...]. Olhe... Para mim assim... Não está tendo muito lucro. Não está tendo muito lucro por quê? Ele simplesmente... Ele fica sentado dentro da sala. Às vezes ele sai no horário do recreio né? Que tem o horário do recreio e ele veme sai para merendar. Aí depois do recreio ele fica. Só que assim... No caso do professor parar... Passar a leitura... Passar... Como é que se diz? As atividades no quadro e ele não consegue acompanhar. Ele não tem aquela habilidade de escrever como os outros alunos. Aí então o tempo passa, o profess or apaga e passa outro trabalho e ele fica só naquilo... Aí uma vez eu cheguei e vim conversar aqui com o professor... Que agora é o professor dele... Aí eu soube de umas coisas aí... Que ele estava saindo um pouquinho ignorante com ele... Isso e aquilo... E eu peguei e vim... Vim fazer... Como é que se diz? Vim fazer o meu papel de mãe. Né? Porque pelo problema dele... Eu vim saber o que estava acontecendo. Aí foi que o professor disse: não, realmente ele é uma criança muito vagarosa mesmo. Ele é muito passivo assim... Só que eu não posso ficar assim... Perder muito tempo com ele porque tem os outros alunos que já tem uma habilidade mais rápida. Né? Porque são os alu nos mesmos que não tem especialidade nenhuma as sim... No caso, não tem problema. Então eu não posso passar muito tempo só com um dever... Só esperando ele. Então ele não tem desenvolvimento nessa área. Na aula normal. [...] Aí foi que eu conversei, foi que eu conheci o professor Batista também. Aí conversei com ele e foi que ele disse que estava saindo esse projeto dessa aula especializada para as crianças com deficiência [...]. Foi pouco tempo. Agora que essa aula especializada veio a acontecer. Todo o desenvolvimento começou no tempo da professora Dora. Aí participava de atividades. Muitas atividades eu participei com ele também. E tudo. Aí já depois da professora Dora foi que ele passou para o poder do professor Batista. E foi daí que já começou o desenvolvimento dele... Nas aulas dele, no... Até mesmo na aprendizagem dele... Ele veio a começar a melhorar por aí". ${ }^{87}$

O aluno com DI I. C. T., conforme relatório escolar (doc. anexo), ainda não reconhece a escrita como representação de ideias comunicativas, visto que tem pouco interesse por atividades que envolvem leitura e escrita, e também encontra dificuldades quanto ao raciocínio lógico. Porém, o mesmo aluno, tem interesse por atividades que envolvem a música (violão), demonstrando percepção auditiva significativa, que poderia ser melhor estimulada. Segundo Raimundo Nonato Torres, pai de I. C. T., aluno com DI, falta capacitação e sensibilização à professora da sala regular para atendimento a seu filho e perceber suas habilidades:

Eu acho que falta capacitação para ela. Porque ela é daqui né? Eela não tem... Assim a... Eu acho que... É... Um aprendizado para lidar com ele (Israel). Lá na escola Bosque a outra tinha, mas ela... Ela não tem. A Sandra não tem. Então teria que ter duas professoras para ele, uma que ensine mesmo... O normal às crianças né? $\mathrm{E}$ a outra que lide bem com isso aí... Quando ele está com essa revolta dele lá dentro da sala. ${ }^{88}$

87 SILVA, Silvânia Gomes, mãe de G. S. do N., aluno da EEEF Marta Conceição. Informações Verbais. Belém, 2015. Entrevista concedida ao autor desta pesquisa.

${ }^{88}$ TORRES, Raimundo Nonato, pai de I. C. T. aluno da EEFM Marta Conceição. Informações Verbais. Belém, 2015. Entrevista concedida ao autor desta pesquisa. 
A Professora Maria Roseline Rodrigues Alfaia, do ensino fundamental da escola pesquisada, em entrevista no dia 24.08.2015 (entrevista anexa), assim se pronunciou ao ser questionada sobre a existência na escola Marta da Conceição da sala multifuncional para atendimento aos alunos com deficiência intelectual e material didático adaptado:

Não tem! Não tem como! Não tem como! Não tem! Não tem nada ali! Não tem como a gente atender o aluno de Educação Especial! Não tem! Porque o espaço ali... Que era... Que é onde a gente atendia... Foi ocupado com turma de ensino regular, de regência... Aí quer dizer... Tirou o espaço que era dos meninos... Tá certo... Não tinha como... Por que... Até porque não tinha espaço, mas eu acho assim... Que foi prioridade? Foi, mas os alunos de Educação Especial eram mais prioridade ainda... ${ }^{89}$

Da forma então como se encara, na maioria das turmas de ensino fundamental observadas na escola, a presença do aluno com deficiência intelectual, verificamos, a visão dos que fazem a escola é para a "limitação" e "incapacidade" desse aluno e das dificuldades para a estrutura organizacional e pedagógica da escola acolhê-lo, e não do quê a escola e seu corpo docente, mesmo com as dificuldades estruturais reconhecidas, pode fazer por ele, e as flexibilizações que podem ser feitas para sua interação com os demais alunos.

A ouvir em entrevista em janeiro de 2016 a Professora Irene Maciel, Coordenadora da Unidade Técnica de Educação Especial de Icoaraci, que tem a função de dar apoio técnico e logístico ao processo de educação inclusiva e especial na escola Marta da Conceição, a mesma descreve as dificuldades logísticas de apoio aquela escola ribeirinha do município de Belém e as barreiras ainda na garantia de atendimento as crianças com DI matriculadas naquele estabelecimento público:

Já que a gente sabe que o processo da inclusão ela é positivada em lei. Foram
surgindo decretos, foram surgindo resoluções [...]. Que ampara toda essa[...]. Esse
público no sistema regular de ensino. Então as escolas começaram, de modo geral, a
se tornarem inclusivas. Mas inicialmente começaram com toda essa escola. Então
por conta dessa ampliação desse alunado nos sistemas de ensino nós tivemos estes
momento. Mas, vamos se dizer, por questões que... Vamos se dizer... Mesmo de
política de governo de estado e pelas condições que a gente tem hoje... Porque até o
concurso daí... Que nesse primeiro momento não havia, não houve nenhum concurso
de 94 até 2012 . Que teve o concurso Educação Especial. Esses profissionais que
estavam trabalhando na Educação Especial eram profissionais que não tin ham
nenhuma vantagem em trabalhar com esse público. Estavam trabalhando porque se
identificaram com trabalho né? E esse público começou a aparecer nas escolas e eu
comecei a olhar esse sujeito de uma forma diferente, mas eu não tinha nas minhas
vantagens enquanto professor... Ganhar $50 \%$ por estar atendendo essa clientela. Ea
gente... E todo mundo que trabalhava era por realmente por... Gostar... E não tinha

89 ALFAIA, Maria Roseline Rodrigues. Professora da EEEF Marta Conceição. Informações Verbais. Belém, 2015. Entrevista concedida ao autor desta pesquisa. 
assim essa formação, vamos se dizer, inicial... Tanto que eu... Quando eu fiz o curso de Pedagogia na minha grade curricular que era antigamente... Era especialista... Eu não vi uma disciplina que se tratasse de Educação Especial. Tudo que eu construí de conhecimento na área da Educação Especial, até a presente data, foram porque eu fui trabalhar com esse alunado... Senti necessidade... E como naquele momento quando eu... Em 92 quando eu iniciei esse trabalho era... A gente teve formações direto né? E com pessoas que já estavam atuando e que tinham experiência e que serviam de... Assim... De apoio para nós que estávamos iniciando ${ }^{90}$.

E continua a coordenadora ao mostrar as dificuldades e algumas barreiras que com esforço próprio teve que transpor para o atendimento desse alunado especial:

Porque a USE... A UTEES... Ela tem sob a sua jurisdição as escolas pertencentes... Pertencentes a USE 11, 12 e 13. Somando as... As escolas que pertencem a essas três USE... Dá cinquentas escolas... Das cinquenta escolas e uma unidade especializada, que é a nossa. São 51 espaços educacionais. Vejam: cada espaço desse tem uns... Deve ter em média 70, 80 professores trabalhando. Então some o quantitativo... A dimensão de profissionais que precisam estar neste processo de formação contínua... Do professor do regular que está na regência e está com esse aluno incluído na sua turma, como o professor que está realizando atendimento educacional especializado precisa dar esse suporte, tanto não só para o aluno... Quanto também para o professor. E hoje por essas dificuldades que eu acabei de falar: falta de recursos financeiro, a falta de uma equipe para poder organizar todo esse trabalho... Eu digo que a formação continuada, não só a nível de Icoaraci como... Para quem conheceu o trabalho antes como eu, que já estou 24 anos... Estou completando, agora em maio, 24 anos só na Educação Especial. Eu não passei por outro segmento. Eu comecei a minha vida profissional na Educação Especial. E dizendo assim... Quando eu assumi a primeira turma de deficiência mental com 15 alunos eu chorei desesperada... Porque eu não sabia o que fazer. Porque ali tudo para mim era novo. E eu acredito, sem medo de errar, que aconteceram com demais profissionais porque naquele momento não se tinha uma visibilidade desse público e do trabalho que era desenvolvido com eles. E aí foi tudo uma construção realmente de conhecimento .

$\mathrm{Na}$ verdade doutor Macieira eu vejo assim... A política ela veio... Esse movimento, na verdade, ele veio. As leis estão aí... Mas o quê que ainda está faltando? Na verdade os sistemas de ensino eles não estão preparado ainda, como eles deveriam estar. Por exemplo, lá eu não conheço a realidade que o senhor está colocando lá na ilha... Classes de multis seriada. Como é que eu digo? Que lá na legis lação diz assim: que eu tenho que ter uma redução... Redução de $10 \%$ de um aluno com deficiência dentro daquela turma. Se eu estou com uma classe multisseriada? Está contradizendo totalmente o que a legislação está dizendo. E porque que elas são multisseriadas? Porque nós não temos escolas... Se aqui eu tenho, em média, quatro alunos... Que é no centro da cidade, aqui no distrito de Icoaraci. Eu estou com um pepino na mão para resolver... Está aí a Sandra... Eu estou em média com quatro alunos autistas numa classe regular[... $]^{91}$.

Em estudo publicado sobre as representações no atendimento educacional especializado, a pedagoga paraense Ivanilde Apoluceno de Oliveira entende que a prática tradicional ainda é que os discentes com deficiência intelectual tenham que se "integrar" ao

90 MACIEL, Irene, Coordenadora da Unidade Técnica de Educação Especial de Icoaraci. Informações Verbais. Belém, 2015. Entrevis ta concedida ao autor desta pesquisa.

${ }^{91}$ MACIEL, 2015. 
contexto escolar e essa "integração" depende de sua adaptação, enquanto indivíduo, ao modelo escolar estabelecido. Diante disso temos uma política de educação inclusiva definida na lei, mas ainda com sua prática limitada em boa parte das escolas, como a da escola Marta da Conceição pesquisada, onde a prática em sua boa parte ainda é de uma visão integradora, já formalmente ultrapassada (como explanado no capítulo anterior), mas que ainda permanece nas mentes e práticas cotidianas de boa parte do corpo docente e administrativo da escola. A referida Ivanilde Apoluceno de Oliveira ${ }^{\mathbf{9 2}}$ assim diz:

O olhar e prática da escola para os/as alunos/as especiais é de "não pertencimento" ao grupo de alunos/as ditos "normais" e às "classes comuns" [...] A escola ao selecionar, estipular rótulos, culpar indivíduos pelos fracassos e justificar a sua organização social injusta nega seu papel de educadora para a formação crítica, criativa e autônoma do ser humano".

Então, apesar de uma normativa e diretrizes políticas para uma educação inclusiva, ainda há resistências em sua aplicabilidade, reproduzindo práticas integradoras e excludentes, que precisam ser extirpadas nesse novo contexto educacional. Agrava-se a isso a inércia do estado em prover com melhores condições materiais a escola para que facilite a atuação dos profissionais junto ao alunado com DI.

Mas é importante registrar que das entrevistas com os pais dos alunos com deficiência intelectual e alguns professores, como dos pais entrevistados dos dois alunos, do próprio professor Batista entrevistado, e até mesmo com o Diretor da escola Pedro Henrique e parte da equipe da UTEEs de Icoaraci, ficou evidente um despertar de uma visão ético-crítica sobre essa prática excludente, a partir da consciência, principalmente dos familiares, de que esses alunos com deficiência intelectual são vítimas desse sistema educacional que ainda reproduz práticas antigas e excludentes de escolarização onde se procura um aluno padrão, e não a convivência com a diversidade, o reconhecimento do aluno como sujeito, como indivíduo com suas particularidades, que através da prática cotidiana e libertadora da escola e da convivencialidade $^{\mathbf{9 3}}$ com os professores e demais alunos pode superar a problemática de sua exclusão e das barreiras atitudinais e ambientais que o circundam. A inclusão de fato precisa que a escola atual se reestruture e tenha outra organização focada em práticas que respeite e

\footnotetext{
92 OLIVEIRA, 2004, op cit., p.195-196.

93 Ivan Ilich, em sua obra Convivencialidade (1973), afirma que a escola precisa mudar para que ocorra a verdadeira inclusão escolar, e essa mudança se fundamenta na convivencialidade, entendida como uma inversão da relação homem-ferramenta. A escola convivêncial propicia condições para que as pessoas participem na criação da vida social; essa escola não é um instrumento que domina o homem, ela representaria o enraizamento na vida concreta das crianças, posto que considera a criança real e não a criança ideal.
} 
acolha a diversidade, aceitando o aluno como ele é, com suas necessidades educacionais especiais.

Esse movimento ético-crítico que busca uma prática libertadora e de autonomia dos alunos com deficiência, na perspectiva freiriana ${ }^{\mathbf{9 4}}$, observada nos familiares e alguns profissionais da escola, nos dá esperança e a possibilidade de que algo possa mudar em benefício dos alunos com deficiência intelectual da Escola Marta da Conceição na busca pela igualdade e dignidade que garantirão sua cidadania plena num País complexo como o nosso. Foi através desse movimento ético-crítico da comunidade que foi possível denunciar e buscar nas autoridades judiciais e do Ministério Público locais o descaso do Estado do Pará com a escola pesquisada e buscar melhorias físicas nesse estabelecimento de ensino e monitorar melhor esse processo inclusivo. O subcapítulo seguinte mostra esse iniciar de um processo de pertencimento da escola pela comunidade e pais dos alunos, para que o Estado dote a escola de um mínimo de condições para seu funcionamento e garantia de qualidade de ensino aos alunos com e sem deficiência na itha.

\subsection{A Ação judicial proposta pelo Ministério Público em prol dos alunos da Escola Marta Da Conceição}

O Ministério Público do Estado do Pará (MPE), através da $3^{\text {a }}$ Promotoria de Justiça Cível de Icoaraci, com atuação na Infância e Juventude, ajuizou em abril de 2013 uma Ação Civil Pública, tipo de ação com efeito mandamental com obrigação de fazer ao réu, no caso, o Governo do Estado do Pará e a Secretaria de Estado de Educação (SEDUC), para garantir reforma física, serviços de qualidade educacionais e funcionamento regular da EEEF Professora Marta da Conceição na ilha de Cotijuba, Distrito de Icoaraci, em Belém, Pará, Amazônia, com fundamento no art. 129, inciso III da Constituição Federal; art. 210, inciso I; 208, parágrafo único e art. 201, inciso V, do ECA.

Nessa ação o Ministério Público afirmou que, em outubro de 2009, o Conselho Tutelar de Outeiro, localizado no Distrito de Icoaraci, em Belém, encaminhou ao MPE uma ata da assembleia geral do Conselho escolar da Escola Estadual de Ensino Fundamental Professora

\footnotetext{
94 Paulo Freire, em Pedagogia do Oprimido, RJ: Paz e Terra.2005, p.58/59, diz que ninguém liberta ninguém, ninguém se liberta sozinho, somente quando os oprimidos descobrem, nitidamente, o opressor, e se engajam na luta organizada por sua libertação, começam a crer em si mesmos, superando assim, sua convivência com o regime opressor. O diálogo crítico e libertador, a reflexão e a ação, são fases e momentos para a libertação desses oprimidos e a transformação da realidade.
} 
Marta da Conceição, denunciando algumas irregularidades no seu funcionamento; que a citada ata apontava para a falta de professores e aula, que vinha se agravando desde 2007; professores destratados sem reposição de novos, segurança na área da escola, falta de quadra de esportes e de lazer; remoção de banheiros localizados próximos a cozinha e área de refeitório e o não-funcionamento da sala de informática, fora carteiras quebradas e condições insalubres nas salas de aula onde ficavam os alunos infantes.

Em razão disso o MPE instaurou um procedimento administrativo (PA) (cópia anexa) para apurar a falta de professores, bem como a precária estrutura física da escola. $\mathrm{O}$ citado procedimento foi convertido em Inquérito Civil no 032/2011. O Promotor de Justiça que subscreveu a ação judicial, solicitou vistoria técnica na escola em 29 de novembro de 2012, realizada em 01 de fevereiro de 2013. A vistoria referida, então concluiu:

[...] que a escola possuía quatro (4) anexos naquela época; que somente tinha sido possível a visita na sede na Ilha de Cotijuba e no Centro Comunitário onde estariam estudando os alunos do anexo Tiradentes, pois o prédio da escola já estaria em reforma e os demais anexos são afastados da Ilha de Cotijuba; que a estrutura física da escola é composta por sete (7) salas de aula, uma (1) secretaria e arquivo; uma sala onde funcionam a direção e a coordenação conjuntas; uma (1) sala de informática, uma (1) sala de SAPE para alunos com necessidades especiais; três (3) depósitos, três (3) banheiros e uma (1) copa. Há um anexo que serve de sala dos professores e de apoio aos docentes que não residem na Ilha de Cotijuba. A escola funciona nos três (3) turnos e oferece à comunidade os ensinos de Educação Infantil, Fundamental I e II e Médio, nas modalidades regular e EJA. Informou, ainda, a vistoria, que a escola não estava autorizada a funcionar, pois não é reconhecida pelo Conselho Estadual de Educação do Estado do Pará, o que já teria sido solicitado no mês de dezembro de 2012, que a escola funciona com 865 alunos, 33 professores, 2 técnicos e 9 servidores de apoio; que em 2012 houve a falta de professor na disciplina língua portuguesa; que, segundo a direção, faltam servidores (2 merendeiras e 2 porteiros); que os professores existentes, com exceção dos lotados no Ensino Fundamental I, todos, possuem nível superior, mas não há programa de formação continuada; a escola não possui biblioteca e o laboratório não funciona pois nunca foi lotado um professor para ministrar aulas, desde 2009; que, quanto a estrutura curricular, foram detectadas algumas irregularidades, como a falta de carga horária para a EJA, Ensino Médio e Fundamental II (a escola está trabalhando com um número deficitário de aulas para determinadas disciplinas), contrariando a legislação educacional que prevê o mínimo de carga horária semanal e mensal, be m como o número mínimo de dias letivos a serem cumpridos; o calendário escolar não observa os 200 dias letivos; os recursos pedagógicos são insuficientes ou inexistentes, sendo também precária a prática de esportes; que há pendência nas prestações de contas de 2009, que implica na falta de verbas para a escola (as prestações de contas não são encaminhadas em tempo hábil) e que o mobiliário é precário e insuficiente.

Apesar de todas essas dificuldades, e devidamente notificado, o Estado do Pará, através da SEDUC, sem qualquer motivo plausível, ficou inerte, descumprindo preceito legal ao deixar de prever no orçamento, aprovado para exercício daquele ano de 2011, verba destinada a educação infanto-juvenil, omitindo-se de praticar atos de sua competência, o que 
poderia caracterizar, em tese, ato de improbidade administrativa. Relevante frisar que a criança tem prioridade absoluta, por força do art.227 da Constituição Federal, além de que o ensino fundamental é obrigação do Estado oferecer, com base no art.205 da mesma Carta Cidadã.

Sem êxito na atuação extrajudicial, o Ministério Público, em 9 de abril de 2013 ajuizou ação civil pública, cujo processo tem número 00018947220138140201, e foi distribuído à 3a. Vara Cível Distrital de Icoaraci-PA (peças anexas), onde o Estado, como réu, deveria realizar uma reforma geral na escola com salas adequadas, bebedouros, banheiros acessíveis, além da criação de espaços com mobiliário adequado para a direção, a secretaria, o setor pedagógico e o corpo docente, a reordenação do número de alunos matriculados a fim de regularizar a situação dos mesmos no período escolar em andamento, assim como para regularizar a situação da escola no censo escolar. ${ }^{95}$

No dia 06 de setembro de 2013, o Juiz da referida $3^{\text {a }}$ Vara de Icoaraci acatou a ação do Ministério Público e determinou no prazo improrrogável até então de 60 dias que o Estado do Pará providenciasse a reforma estrutural, com o caráter de urgência do prédio onde funciona a instituição, além das condições mínimas para o atendimento educacional dos alunos matriculados, dentre eles, os alunos com deficiência. Passados sete meses da decisão, e com novas denúncias de precariedade da escola, uma inspeção pelo próprio Juiz, acompanhado pelo Ministério Público, foi realizada no dia 11 de abril de 2014, e o magistrado verificou que as decisões anteriores não haviam sido cumpridas em sua integralidade. E, em nova sentença do dia 15 de outubro de 2014, o juiz destacou que a situação encontrada na escola era estarrecedora. E resolveu determinar novo prazo de 60 dias e nova multa, agora mais alta, no valor de R 3.310 milhões, ao Estado do Pará para garantir o mínimo de funcionamento à escola e condições dignas aos alunos e professores. A reportagem do jornal "O Diário do Pará" esteve em 23 de novembro de 2014 na Escola Marta da Conceição, na Ilha de Cotijuba, e constatou a precariedade em que viviam os alunos e funcionários. E afirmou a reportagem que não havia o mínimo de condições estruturais e administrativas, e que a instituição abrigava 700 alunos, divididos em três turnos. Na reportagem o representante da comissão de estudantes da Escola Maria da Conceição, Alessandro Oliveira, desabafou:

\footnotetext{
${ }^{95}$ PARÁ. Ministério Público. ICOARACI: MP ajuíza ACP contra o Estado por condições precárias em escola na Ilha de Cotijuba. 12.04.2013. Disponível em: http://www.mppa.mp.br/index.php?action=Menu.interna\&id=2182 \&class $=$ N. Acess o em: 26.07.2015.
} 
Hoje, estudar na escola Marta da Conceição está quase impossível. E isso porque a estrutura é precária. Nós não temos material escolar, ventiladores, biblioteca, banheiro, e nem uma quadra para fazer educação física. Os estudantes aqui não têm quase nada. Nem merenda, nem água para tomar. Hoje tomamos água da torneira, porque não temos filtro. A situação é tão séria, que não temos nem diretora. ${ }^{96}$

Nos autos do referido processo judicial, o Juízo da Vara Cível de Icoaraci, distrito de Belém-Pará, emitiu liminar em 2014 para o Estado do Pará e SEDUC e a direção da escola Estadual Marta da Conceição cumprirem o seguinte:

Determino LIMINARMENTE e sem prévia justificação, com fundamentação no art. 123 e respectivos parágrafos, do Estatuto da Criança e do Adolescente, e antecipação do provimento final, consistente em, no prazo de 15 dias úteis:

a) Revisão do Projeto Político Pedagógico em sua essência;

b) Regularização da escola junto ao Conselho Estadual de Educação, nos prazos estabelecidos;

c) Cobrança da Secretaria de Educação quanto ao retorno da prestação de contas do Conselho Escolar;

d) Reeleição para o Conselho Escolar;

e) Aquisição de recursos pedagógicos e tecnológicos diversos e em número suficiente;

f) Construção e implementação de biblioteca onde possa contemplar os alunos com novas e diversificadas bibliografias;

g) Capacitação docente;

h) Reforma geral da escola, segundo relatório da Técnica do CAO's que será objeto de outra ação civil;

i) Construção de espaço poliesportivo;

j) Criação de espaços com mobiliário adequado para direção, secretaria, setor pedagógico e corpo docente;

k) Reordenação do número de alunos matriculados a fim de regularizar a situação dos mesmos no período escolar em andamento, assim como regularizar a situação da escola no que concerne às informações de censo escolar e outros;

1) Cumprimento efetivo da estrutura curricular para os níveis de ensino praticados na escola no que diz respeito ao número de horas dispostas para cada disciplina;

m) Cumprimento por parte da Secretaria Executiva de Educação da lotação docente completa da escola e seus anexos, em todas as suas disciplinas e crga horária semanal;

n) Criação de política de incentivo ao docente lotado em zonas de carência como a Ilha de Cotijuba;

o) Concedida a LIMINAR ou com a sentença final, pleiteia-se a imposição de multa diária ao Estado do Pará, conforme o art. 11, da Lei 7.347, de de 24 de julho de 1985, equivalente a 200 (duzentos) UFIR, em caso de não cumprimento da liminar e não providenciado o repasse das verbas pecuniárias previstas no orçamento;

p) Requer a determinação de outras medidas provisórias que forem adequadas, pois há fundado receio de que o Estado do Pará, antes do julgamento da lide,cause prejuízo aos direitos da infância e juventude lesão grave e de difícil reparação (art. 798, do CPC).

Novamente, e por duas vezes notificados, e em segunda decisão judicial, provocado pelo Ministério Público, que referendava a medida judicial anterior, o Estado do Pará e

96 EDUCAÇÃO: escola estadual é visão do purgatório. Diário do Pará on line. 23.11.2014. Caderno Atualidades. Disponível em: http://www.diarioonline.com.br/noticias-interna.php?nIdNoticia=310135\&idrand=156. Acesso em: 26.08.2015. 
SEDUC continuaram omissos às providências em relação a escola pesquisada, em prejuízo dos alunos, principalmente crianças e aquelas com deficiência, e a comunidade da ilha de Cotijuba. Foi necessário a intervenção do Tribunal de Justiça do Estado do Pará, ao final de 2014, ao compelir o Governo do Estado, sob pena de multa e ato de improbidade administrativa de seu gestor, para que se iniciasse efetivamente providências de construção, adaptação e preservação do prédio da escola, além de equipar a escola de condições mínimas e dignas para o alunado, docentes e corpo diretivo. O que foi incluído e oportunizado no orçamento e 2015 com processo licitatório para que empresa terceirizada iniciasse trabalho de reforma da escola, ao mesmo tempo que o Estado adquiriu carteiras, materiais pedagógicos, equipamentos de refrigeração e novas instalações sanitárias.

As obras efetivamente só iniciaram em agosto de 2015 quando das primeiras visitas desse pesquisador e em conclusão este ano de 2016, e ainda, sem garantia de que essas reformas abranjam os dois anexos de Urubuoca e Pedra Branca, que se encontram ainda em estado precário de conservação.

Tal fato reforça nossa tese de que o problema maior na garantia da educação dos infantes com deficiência está na política, no cumprimento das políticas públicas prescritas nas leis e programas estatais. O estado dá com uma mão, ao garantir os direitos formalmente, e retira com a outra, ao não implementá-los por ação ou omissão dos órgãos responsáveis pela execução das normas.

A educação, assim como a saúde incluem-se entre os direitos essenciais e fundamentais ao cidadão por força da Constituição Federal e dos princípios que regem os direitos humanos de segunda geração. Gilmar Mendes e Paulo Gonet Branco, ao afirmarem a educação como direito fundamental e essencial ao ser humano assim prelecionam:

Dentre os direitos sociais, o direito à educação tem assumido importância predominante para a concretização dos deveres tutelados pela Constituição e, principalmente, para a construção de patamar mínimo de dignidade para os cidadãos. [...] A necessidade de consolidar o direito à educação como direito fundamental foi bastante discutida no processo constituinte. A preocupação com a concretização desse direito social e a busca para superar a ineficiência do modelo educacional brasileiro acabaram por dar origem ao mandado de injunção. Concebido para a proteção do direito à educação, objeto desse novo instrumento passou a compreender ouras omis sões do estado. ${ }^{97}$

97 MENDES, Gilmar; BRANCO, Paulo Gonet. Curso de Direito Constitucional. São Paulo: Saraiva, 2015, p.650-651. 
Lauro Ribeiro, também reafirma esse posicionamento ao declarar que educação e a saúde são as únicas áreas sociais a receber tratamento distinto da regra geral de vedação constitucional de vinculação de receita pública (art. 167, IV e art. 218, § $\left.5^{\circ}\right)^{98}$. Tal argumento é reforçado por Fábio Konder Comparato e Élida Graziane Pinto que em trecho de recente artigo dizem:

Interessante aqui retomarmos a perspectiva de que o princípio geral de não afetação da receita de impostos admite a exceção aberta pelo artigo 167, inciso IV, em sua parte final, em favor da proteção aos direitos fundamentais à saúde e à educação. Em uma interpretação sistemática, depreendemos que os patamares de gas to mínimo em favor de tais direitos, de fato e de direito, já são considerados como conteúdo imutável das legislações orçamentárias, até para que se possa aferir a aventada restrição da "reserva do possível" para fazer face às demais políticas públicas.

Estamos em pleno processo pedagógico e civilizatório de assegurar a saúde, a assistência e a previdência social, bem como de educar nossos cidadãos, o que não pode ser obstado ou preterido por razões controvertidas de crise fiscal. Hoje, mais do que nunca, o mínimo de vida digna passa pela garantia dos direitos fundamentais em comento. Nada há de mais prioritário nos orçamentos públicos que tal desiderato constitucional, sob pena de frustração da própria razão de ser do Estado e da pactuação social que ele encerra. ${ }^{99}$

Importante neste diapasão, registrar o voto do Ministro Celso de Melo do Supremo Tribunal federal na Ação de descumprimento de preceito fundamental (ADPF n.45), que foi acompanhado pelos demais ministros daquele excelso Tribunal, no sentido de dar essencialidade e prioridade orçamentária e fiscal as políticas públicas da educação e saúde, principalmente em direitos prioritários como a da criança e pessoa com deficiência. Neste belo voto vencedor e paradigmático assim preleciona Celso de Melo:

\begin{abstract}
Impende assinalar que a regra legal em questão - que culminou por colmatar a própria omissão normativa alegadamente descumpridora de preceito fundamental - entrou em vigor em 2003, para orientar, ainda em tempo oportuno, a elaboração da lei orçamentária anual pertinente ao exercício financeiro de 2004. Conclui-se, desse modo, que o objetivo perseguido na presente sede processual foi inteiramente alcançado com a edição da Lei $n^{\circ} 10.777$, de 24/11/2003, promulgada com a finalidade específica de conferir efetividade à EC 29/2000, concebida para garantir,
\end{abstract}

\footnotetext{
${ }^{98}$ RIBEIRO, Lauro Luiz Gomes. Direito Educacional: Educação Básica e Federalismo. São Paulo: Quartier Latin, 2009.

${ }^{99}$ Comparato, Fábio Konder; Pinto, Élida Graziane. Custeio mínimo dos direitos fundamentais, sob máxima proteção constitucional. Disponível em: http://www.conjur.com.br/2015-dez-17/custeio-minimo-direitosfundamentais-maxima-protecao-cf. Acesso em: 04.07.2016.
} 
em bases adequadas - e sempre em benefício da população deste País - recursos financeiros mínimos a serem necessariamente aplicados nas ações e serviços públicos de saúde. Não obstante a superveniência desse fato juridicamente relevante, capaz de fazer instaurar situação de prejudicialidade da presente arguição de descumprimento de preceito fundamental, não posso deixar de reconhecer que a ação constitucional em referência, considerado o contexto em exame, qualifica-se como instrumento idôneo e apto a viabilizar a concretização de políticas públicas, quando, previstas no texto da Carta Política, tal como sucede no caso (EC 29/2000), venham a ser descumpridas, total ou parcialmente, pelas instâncias governamentais destinatárias do comando inscrito na própria Constituição da República. Essa eminente atribuição conferida ao Supremo Tribunal Federal põe em evidência, de modo particularmente expressivo, a dimensão política da juris dição constitucional conferida a esta Corte, que não pode demitir-se do gravíssimo encargo de tornar efetivos os direitos econômicos, sociais e culturais - que se identificam, enquanto direitos de segunda geração, com as liberdades positivas, reais ou concretas (RTJ164/158-161, Rel. Min. CELSO DE MELLO) -, sob pena de o Poder Público, por violação positiva ou negativa da Constituição, comprometer, de modo inaceitável, a integridade da própria ordem constitucional: "DESRESPEITO À CONSTITUIÇÃO - MODALIDADES DE COMPORTAMENTOS INCONSTITUCIONAIS DO PODER PÚBLICO. - O desrespeito à Constituição tanto pode ocorrer mediante ação estatal quanto mediante inércia governamental. ${ }^{100}$

Verifica-se, assim, que se não fosse o movimento da sociedade da ilha de Cotijuba, corporificado na representação ao Conselho Tutelar, que chegou ao Ministério Público e Judiciário, a escola pesquisada continuaria funcionando precariamente sem instalações físicas e de pessoais adequadas. Não que hoje esteja em ótimas condições, mas já em condições satisfatórias para o transcorrer do ano letivo, principalmente no ensino fundamental obrigatório, e para o atendimento regular dos alunos com deficiência e os demais, incluindo os docentes e corpo diretivo da escola.

Encerramos este capítulo, citando mais uma vez o jurista Lauro Ribeiro, que bem diz em seu Direito Educacional, às fls. 304:

\footnotetext{
Há um longo caminho a ser percorrido para uma melhora na educação do povo brasileiro, que passa pela priorização absoluta do ensino fundamental, tanto da criança como do jovem e do adulto, que a ele não tiveram acesso na época apropriada - obrigatório na "sociedade educativa" preconizada por Delors -, que significa o aprender a escrever a própria vida, conscientizar-se, permitindo que se pense o mundo sob a perspectiva de poder julgá-lo. Esta fase é a porta de entrada para uma educação universal, isto é, organizada e ampliada de maneira que seja possível ministrá-la a todos, sem distinção de qualquer ordem, eliminando-se os preconceitos e os estereótipos de qualquer natureza e, com ela, a emancipação do povo, cartão de embarque para uma verdadeira viagem democrática que terminará num mundo de paz, onde impere a solidariedade internacional, haja relações econômicas honestas e equitativas e em que o direito de fruição de uma vida digna seja privilégio de todos e não de poucos ou muito poucos. ${ }^{101}$
}

100 MELO, Celso, Rel. ADPF - Políticas Públicas - Intervenção Judicial - "Reserva do Possível" (Transcrições) ADPF 45 MC/DF. Diário Oficial [da] República Federativa do Brasil. Brasília, 14 de julho de 1990. Disponível em: https://www.planalto.gov.br/ccivil_03/leis/L8069.htm. Acesso em: 04.05.2014.

${ }^{101}$ RIBEIRO, 2009. op. cit. 


\section{FUNDAMENTOS PARA UM PROCESSO INCLUSIVO}

\subsection{Igualdade, Desigualdade, Exclusão e Inclusão: uma pequena análise a partir dos dados coletados.}

Após discorrermos, no primeiro capítulo, sobre as normas que fundamentam o processo de inclusão educacional dos alunos com deficiência intelectual e seguidamente no segundo capítulo fazermos uma descrição e análise dos dados coletados na escola pesquisada, podemos levantar algumas questões relevantes sobre o atendimento educacional aos alunos com deficiência intelectual naquele estabelecimento: 1.A escola não possui a estrutura física e de pessoal adequada para o atendimento dos alunos com deficiência intelectual, muito menos planejamento pedagógico para esse atendimento, inclusive inexistindo Projeto Político Pedagógico (PPP) como previsto no PNE e PEE, e Conselho Escolar em funcionamento; apesar do apelo constante da direção da escola junto a direção da Secretaria Estadual de Educação 2- o Estado, através da Secretaria de Estado de Educação e Unidade Técnica de Educação Especial de Icoaraci, não oferece ainda, apesar dos reclamos da direção da escola, e da ação judicial do Ministério Público com decisões judiciais mandamentais, todos os recursos materiais necessários à escola para que ela garanta instalações físicas adaptadas, incluindo salas multifuncionais e material pedagógico adaptado; além de capacitação contínua de pessoal na área da educação especial e inclusiva; 3- Os professores ouvidos, em sua maioria, não estão sensibilizados e cientes do processo de inclusão, do conviver na diversidade, do acolhimento ao diferente, na flexibilização curricular e do conteúdo ministrado na sala de aula em relação aos alunos com deficiência intelectual, reforçando conceitos tradicionais e discriminantes, e por consequência a desigualdade e exclusão desses alunos. 4- A reação dos pais dos alunos, a partir dos pais entrevistados do alunos com DI, do engajamento do diretor Pedro Henrique por melhorias na escola; e da resistência observada do professor em educação especial Batista, em defender mudanças no atendimento educacional especial na escola para um melhor reconhecimento das suas necessidades, ainda não foram suficientes para mudar o panorama de precariedade no acolhimento desses alunos na escola Marta da Conceição.

Diante desses pontos identificados acima, a pesquisa de campo revela efetivamente uma desigualdade no tratamento educacional dispensado aos alunos com deficiência intelectual na Escola Estadual Marta da Conceição, apesar de uma nova e clara política 
educacional normatizada que afirma a inclusão e os direitos humanos das pessoas com deficiência. Mas que igualdade de tratamento queremos, dentro de um viés jurídico-político?

Em um primeiro aspecto, é preciso discorrermos que a igualdade, no sentido formal, foi estatuída como princípio no art. $5^{\circ}$, caput, da Constituição Federal, afirmando a concepção de que todos devem ser respeitados e tratados igualmente. Para Ronald Dworkin, esta concepção se trata da igualdade de consideração e respeito requerida mutuamente entre todos os indivíduos. Ela cria também o alicerce das ações políticas e determina projetos governamentais para garantir essa igualdade ou diminuir as desigualdades existentes. É propriamente a partir desse direito básico à igualdade que ele justifica os outros direitos legislativos, econômicos, políticos etc. E no nosso caso, essa concepção de igualdade, num primeiro momento, justifica o direito à inclusão na educação regular das crianças com deficiência intelectual junto com os demais alunos na classe comum.

Mas entendemos, aproveitando ainda as lições de Dworkin, quando na obra A Matter of principle, Dworkin sustenta que em uma perspectiva liberal ${ }^{102}$ na qual a idéia de igualdade como ideal político requer igual respeito e consideração recíprocos a e de todos, e é precisamente por isso que o igualitarismo liberal exige que "o governo trate a todos aqueles que estão sob sua responsabilidade igualmente na distribuição de algum recurso de oportunidade"103. Como verificamos, Dworkin sustenta que certas condições mínimas devem ser garantidas pelo Estado para que os cidadãos realizem seus projetos existenciais. Esse mínimo no caso dos alunos com deficiência intelectual da escola Marta da Conceição é estarem juntos com os demais, consoante determina a própria normativa a eles aplicável como vimos no primeiro capítulo. Em dúvida a pesquisa revela que estão inseridos. No entanto, a

102 Em boa parte da tradição norte-americana o termo liberal é sinônimo de progressista em oposição à republicano como conservador. Aqui neste estudo acatamos a versão de liberalismo proposto por Ronald Dworkin, denominado Liberalismo Igualitário. Para Ana Marcia Nunes Cardoso, em dissertação na UFSC (http://repositorio.ufsc.br/xmlui/handle/123456789/88135) denominado "O liberalismo em Dworkin: uma releitura dos princípios liberais", esclarece que esse liberalismo de Dworkin é fundado na concepção da integração e na ética igualitária, assim, estabelecendo uma releitura dos princípios liberais, tendo em vista que elege a igualdade como núcleo. Para tanto, o autor rechaça as correntes utilitaris tas e positivistas, sustentando o direito como interpretação e integração. Desenvolve sua teoria por meio da interdisciplinaridade, pois o exame do autor vai além de uma teoria do direito, almeja constituir uma concepção de comunidade política inovadora, sendo que seu pensamento é estruturado pela correlação entre o modelo judicial e o modelo político. A nova visão em relação aos princípios liberais se afasta das concepções clássicas do liberalismo que elege o indivíduo como o único núcleo, pois Dworkin ressalta o papel da comunidade, principalmente como ponto primordial para a constituição das identidades dos sujeitos. Desta forma, para esclarecer a importância de uma vida comunal política e seus limites, a teoria do autor se delineia por um processo din âmico de auto-reconhecimento dos cidadãos e da composição de objetivos comuns, capaz de produzir um vínculo ético baseado na igualdade, com o intuito de promover uma integração entre a comunidade e o indivíduo.

103 DWORKIN, 2012, op. cit., p. 190. 
pesquisa também revela que, na escola Marta da Conceição, apesar de inseridos na turma, não se encontram, de fato, incluídos. As barreiras elencadas no início deste capítulo e detectadas e explanadas no capítulo anterior, permanecem, pois não foram superadas por medidas concretas do estado para dirimi- las.

Não adianta nada eu garantir princípios e regras para inclusão do aluno DI na escola comum no ordenamento jurídico, se o mesmo Estado que o regulamenta, não dá as ferramentas e recursos necessários para realização dessas normas. E, ainda, o corpo docente dessa escola não se compromete com ações que superem a crença na incapacidade naturalizada e na necessidade da segregação dos alunos com deficiência. Sem a garantia do igual respeito e consideração para com esse segmento discriminado de crianças internalizado por seus operadores, está-se, como revelam as práticas cotidianas naquela escola, reforçando o estigma da diferença e da discriminação, agravando uma situação de vulnerabilidade, ao invés de se buscar garantir condições para se fomentar a autonomia e a autoestima desse grupo de pessoas.

A Constituição em seus artigos 205 e 208 e a Convenção Internacional sobre os Direitos das Pessoas com Deficiência em seu art.24, definiram a educação como um direito fundamental de todas as crianças, e, óbvio, aí incluído, como vimos, as crianças com deficiência. Portanto, também a elas é hoje garantido esse direito humano fundamental de segunda geração à educação, que, como sabemos com Ronald Dworkin, requer sejam normativamente fixados no interior do próprio direito os comandos delineadores de uma política educacional especiffica capaz de atender às suas necessidades especiais. Assim, é o próprio direito fundamental à igualdade dessas crianças que, no campo educacional, exigirá o seu tratamento normativo diferenciado mediante a formulação de parâmetros para a execução de uma política de ensino complexa que também seja capaz de atender adequadamente às especificidades desse grupo de alunos. Portanto, com o apoio da doutrina de Ronald Dworkin, é possível destacar e aprofundar a compreensão da articulação, interna ao Direito, entre a afirmação de determinados direitos e a institucionalização normativa de políticas específicas voltadas para a efetivação desses mesmos direitos. ${ }^{104}$

Entre os princípios dispostos na Constituição, como vimos, está o que garante que o ensino será ministrado com base na igualdade de condições para o acesso e permanência na escola (art.206, I), e cabe ao Estado o dever de efetivar a educação infantil mediante a garantia de educação básica obrigatória e gratuita (art.208, I), e em relação aos que tem 
deficiência, inclui ainda, precisamente para atender à diferença específica desses alunos, o apoio especializado no ensino regular (art.208, III).

Em relação a Convenção ela tem o propósito de promover, proteger e assegurar o exercício pleno e equitativo de todos os direitos humanos e liberdades fundamentais por todas as pessoas com deficiência e promover o respeito pela sua dignidade inerente $\left(\operatorname{art} .1^{\circ}\right)$, obrigando o Estado em todos os programas e políticas, a garantir a proteção e a promoção dos direitos humanos das pessoas com deficiência ( $\operatorname{art} .4^{\circ}, 1, \mathrm{c}$ ), e que estas pessoas não sejam excluídas do sistema educacional geral sob alegação de deficiência e, principalmente, as crianças, não sejam excluídas do ensino primário gratuito e compulsório ou do ensino secundário, sob alegação de deficiência; e que possam ter acesso ao ensino primário inclusivo (entendido como ensino fundamental em nosso sistema atual), de qualidade e gratuito, em igualdade de condições com as demais pessoas na comunidade em que vivem (art.24). Para tanto, é relevante que se destaque que é a própria igualdade de oportunidades que juridicamente requer a determinação de uma política educacional complexa que também incorpore o cuidado para com o atendimento das necessidades especiais dessas crianças.

Desta forma, cabe criar as condições para que as crianças com impedimentos cognitivos tenham direito igual às demais de acesso e permanência na escolas pública regular Marta da Conceição e, assim, se dê concretude ao seu direito à educação e à cidadania desses infantes de da ilha de Cotijuba e entorno. Para tanto, a partir da problemática das barreiras à inclusão educacional de alunos com deficiência intelectual encontradas na Escola Estadual Marta da Conceição, impõe-se ao estado e seus prepostos, principalmente os professores e profissionais da escola, o reconhecimento das diferenças específicas dessas crianças que, precisamente com vistas à possibilitar a igualdade, deverá garantir uma política de ensino adequada às suas necessidades especiais. Apenas essa especificidade de tratamento poderá possibilitar a sua real inclusão. A questão revela a complexidade de que se reveste o direito atual que, ao afirmar direitos universais, não mais pode permanecer cego às necessidades especiais de determinados grupos de pessoas, e para garantir o acesso dessas pessoas a esses direitos, há que internalizar no próprio direito políticas e estratégias de enfrentamento das condições que os obstam. Para igualarmos em certos aspectos temos que desigualar em outros com vistas a atingir o fim de garantir a inclusão. Somos diversos, e a diversidade exige que examinemos na teoria e na prática os desafios e as possibilidades postulados à educação, com vistas a darmos à igualdade de oportunidades e à inclusão educacional dessas pessoas. 
Amartya Sen, em seu livro Desigualdade Reexaminada ${ }^{\mathbf{1 0 5}}$, assim diz:

No nível prático, a importância da pergunta 'igualdade de quê?' deriva da diversidade real dos seres humanos, de tal modo que exigir a igualdade em termos de uma variável tende a ser incompatível - de fato e não somente em teoria - com querer a igualdade em termos de outra. Somos profundamente diversos em nossas características internas (tais como idade, sexo, habilidades gerais, talentos particulares, propensão a doença, e assim por diante) bem como nas circunstancias externas (tais como patrimônios disponíveis, ambientes sociais, problemas graves do meio ambiente, e assim por diante). É precisamente devido a tal diversidade que a ênfase no igualitaris mo em um campo exige a rejeição do igualitarismo em outro.

É necessário, assim, também, além das posturas e práticas dos profissionais da educação a serem mudadas, necessário readequar as estruturas que fazem ou propiciam a desigualdade e combatê-las no sistema vigente, seja com medidas administrativas a partir de um diálogo com a própria comunidade da ilha de Cotijuba e entorno e pais dos alunos matriculados, ou até mesmo judiciais a partir de ações do Ministério Público estadual, como na ação civil pública exposta anteriormente que propiciou reformas na escola.

Neste aspecto, uma política de inclusão educacional nas escolas públicas de crianças com deficiência intelectual se insere como uma política pública de caráter permanente, que se justifica a partir de uma determinada concepção de justiça, a justiça distributiva, com base em um modelo específico, que toma por base um princípio fundamental: a igualdade. Mas não a pura igualdade formal, e nem tampouco uma pura igualdade material, mas sim uma igualdade complexa, que resulte da tensão permanente entre as anteriores, como a prevista no art. $3^{\circ}$. da Constituição Federal, requerendo, a um só tempo, a equiparação de oportunidades com vistas à garantia da autonomia e da independência para o exercício da cidadania. E, neste caso, a educação inclusiva para as crianças com deficiência é um tipo de política constitucional e legal que se aproxima, mas não se confunde com uma ação discriminatória reversa, pois implica numa política permanente de inclusão e igualdade de oportunidades a uma minoria social, ou seja, não se trata aqui de uma ação afirmativa no sentido estrito, técnico, pois está sempre tem um caráter temporário e transitório como afirma Joaquim Barbosa Gomes em seu livro "Ação Afirmativa e Princípio Constitucional da Igualdade - O Direito como instrumento de transformação social. A experiência dos EUA" 106. No caso, o direito à educação é um direito emancipatório para possibilitar a autonomia, a independência, o autodesenvolvimento

\footnotetext{
105 SEN, Amartya. Desigualdade reexaminada. Tradução de Ricardo Doninelli Mendes. Rio de Janeiro: Record, 2001, p. 23.

106 GOMES, Joaquim Barbosa. Ação Afirmativa e Princípio Constitucional da Igualdade: O Direito como instrumento de transformação social. A experiência dos EUA”. Rio de Janeiro : Renovar, 2001
} 
e o exercício da cidadania também às pessoas com deficiência intelectual. Neste aspecto buscamos apoio, mais uma vez, na teoria da igualdade de recursos de Ronald Dworkin definida na obra A Virtude Soberana - A Teoria e Prática da Igualdade ${ }^{107}$ essa concepção de igualdade, ancorada também nas concepções já acima explanadas de Amartya Sen, e de John Rawls, na sua Teoria de Justiça - Justiça como Equidade ${ }^{\mathbf{1 0 8}}$, como estratégia para uma melhor distribuição e garantia de oportunidades às crianças com deficiência intelectual, dentro do tripé igualdade, liberdade e comunidade. Igualdade entendida como igualdade de recursos e oportunidades, liberdade com restrições previamente ajustadas e comunidade como aquela que pratica a tolerância liberal e aplica a inclusão social, respeitando a diversidade.

Outro ponto importante é como aplicarmos esses princípios da igualdade de oportunidades e da inclusão social das pessoas com deficiência numa sociedade democrática e complexa como a nossa na atualidade, e a partir da teoria discursiva de Jurgens Habermas, tal como exposta em sua obra Direito e Democracia ${ }^{109}$, verificarmos a inter-relação entre as idealizações normativas do direito e as realidades empíricas, na tensão tanto interna quanto externa entre facticidade e validade, com vistas à uma contribuição inicial para a avaliação do grau de efetividade da política educacional de inclusão dos alunos intelectualmente deficientes normativamente acolhida para a escolas pública Marta da Conceição do Estado do Pará.

Para Boaventura de Souza Santos (Gramática do Tempo: Para uma nova Cultura Política, Cortez, 2010, p. 280 a 285), a desigualdade e a exclusão são dois sistemas de pertença hierarquizadas, pois no sistema de desigualdade a pertença se dá pela integração subordinada enquanto no sistema de exclusão a pertença dá-se pela exclusão. A desigualdade implica um sistema hierárquico de integração social. Quem está em baixo está dentro e a sua presença é indispensável. Ao contrário, a exclusão assenta num sistema igualmente hierárquico, mas dominado pelo princípio da segregação: pertence-se pela forma como se é excluído. Assim, enquanto o sistema de desigualdade assenta paradoxalmente no essencialísmo da igualdade, sendo por isso que o contrato de trabalho é um contrato entre partes livres e iguais, o sistema de exclusão assenta no essencialismo da diferença, seja ele a

\footnotetext{
107 DWORKIN, Ronald. A virtude soberana: a teoria e a prática da igualdade. Tradução de Jussara Simões. São Paulo: Martins Fontes. 2005.

${ }^{108}$ RAWLS, John. Uma teoria de Justiça. Tradução de Juss ara Simões. 3. Ed. São Paulo: Martins Fontes, 2008.

109 HABERMAS, Jürgen. Direito e Democracia, entre facticidade e validade. Tradução de Flávio Beno Siebeneichler. Rio de Janeiro: Tempo Brasileiro, 2012. V. 1.
} 
cientifização da normalidade, e portanto, da pessoa com deficiência, ou o determinismo biológico da desigualdade racial ou sexual. Para Boaventura, a regulação social num sistema moderno capitalista, como é o nosso sistema brasileiro, ao mesmo tempo que geram desigualdades e exclusões, como ocorre no caso das pessoas com deficiência, por outro estabelecem mecanismos que atenuam ou mascaram essas desigualdades e exclusões, através de programas ou projetos ditos "inclusivos", mas que na verdade visam uma gestão controlada desse sistema, com o fito de reduzir possibilidades concretas de emancipação social.

As desigualdades educacionais ou instrucionais gerais - Os desequilibrios na educação formal, na instrução elementar ou na própria instrução geral - criam desníveis que se refletem no direito. No caso dos alunos com DI da escola Marta da Conceição estas desigualdades ou desequilibrios provocados pela omissão do estado, da desresponsabilidade do corpo docente, e da ausência familiar em alguns aspectos para a garantia da política da educação inclusiva no ensino fundamental do $1^{\circ}$. Ao $4^{\circ}$ ano, fazem com que o direito à igualdade, nos seus múltiplos aspectos, sejam descumpridos, e consequentemente o seu direito fundamental à educação, à cidadania e autonomia.

\subsection{A Inclusão Educacional de Crianças com Deficiência Intelectual na escola comum é Possível.}

Lev Semiónovic Vygotski, nascido em 1896, e falecido em 1934 na Rússia, foi um relevante cientista que analisou detidamente a questão da deficiência e as possibilidades de inclusão educacional do aluno com impedimento intelectual. Em seu livro "Fundamentos de Defectologia" apresentou um sério e profundo estudo sobre o desenvolvimento atípico das crianças com deficiência, fornecendo elementos que nos fazem refletir e repensar atualmente muitas das nossas posições sobre esse assunto tão complexo.

Contrariando métodos quantitativos de investigação, de mensuração, baseados em uma concepção puramente quantitativa do desenvolvimento infantil, nos quais as proporções, o tamanho, a escala são categorias fundamentais para se determinar a insuficiência do impedimento (que o autor chama de "defeito") como se toda a diversidade de fenômenos estudados pela defectologia ficasse englobada por um esquema único mais-menos, Vygotski defende a sua tese básica que diz: 
[...] La defectologia posee su propio y particular objeto de estudio; debe dominarlo. Los processos del desarollo infantil - que ella estudia - presentan una enorme diversidade de formas, una cantidad casi ilimitada de tipos diferentes. La ciencia debe dominar esta peculiaridade y explicarla, estabelecer los ciclos y las metamorfosis del desarrollo, sus desproporciones y centros mutables, descubrir las leyes de la diversidad. ${ }^{110}$

Vygotski fez uma abordagem diferencial sobre o desenvolvimento atípico. Segundo o autor, o próprio processo de desenvolvimento da criança com deficiência é um processo diferente, realizado de outro modo, de forma peculiar. Para ele, o esquema mais - menos faz parte de uma defectologia quantitativa e ultrapassada, que se fundamentava em um padrão socialmente preconcebido, assim a criança com deficiência não é considerada uma criança normal, subtraindo-se dela a capacidade de ver, ouvir, e compreender, pois o desenvolvimento da mesma é qualitativamente diferente, ou seja, distinto daquele considerado como padrão.

Apesar de Vigotsky ter formulado, no início do século passado, a idéia de um desenvolvimento qualitativamente distinto e peculiar da criança com deficiência, muitos educadores ainda hoje desconhecem esse paradigma na educação de crianças com necessidades educacionais especiais e ainda fazem comparações e tomam como referência um padrão socialmente estabelecido.

Relevante também observar que Vygotski faz restrições ao uso de métodos quantitativos de investigação (psicométricos) para a avaliação da deficiência (ou como ele diz do "defeito").

Pois boa parte desses métodos, por não por não fazerem uma análise mais detalhada da capacidade dos alunos com deficiência, muitas vezes acabam rotulando-os de incapazes e consequentemente frustram as expectativas sociais, familiares e escolares sobre seu desenvolvimento. Historicamente fica comprovado que muitas crianças com deficiência intelectual já foram segregadas e sofreram restrições em seu desenvolvimento com base nos resultados obtidos por meio do uso de métodos de mensuração de seu impedimento. É importante que não se crie barreiras às possibilidades educacionais de alunos considerados com deficiência, sustentados por resultados obtidos por meio de métodos quantitativos de avaliação do desenvolvimento infantil, ou seja, por meio de diagnósticos equivocados.

Como meio de evitar esses preconceitos, que excluem os alunos com DI, Vygotski não estabelece comparações, segundo um padrão, entre o desenvolvimento com impedimentos cognitivos e o considerado normal, mas propõe a ideia de processos compensatórios. Para ele,

110 VIGOTSKI, L. S. Obras Escogidas-V, Fundamentos de defectologia. Madrid: Machado Libros, 2012, p.14. 
a deficiência desempenha um duplo papel no processo do desenvolvimento agravado pela insuficiência orgânica e cognitiva e na formação da personalidade da criança:

[...] Por uma parte, el defecto es el menos, la limitacion, la debilidad, la disminución del desarrollo; por outra, precisamente porque crea dificultades, estimula umavance elevado e intensificado. La tesis central de la defectologia es la siguiente: todo defecto crea los estímulos para elaborar uma compensación ${ }^{111}$

A deficiência, principalmente a intelectual, acarreta para Vigotsky uma reação social frente ao sujeito que a possui. Essa situação pode impulsionar no indivíduo um forte desejo de superação, ou seja, pode tornar-se a força motriz para o desenvolvimento psíquico. Torna-se possível transformar o déficit em talento.

Assim, a deficiência pode criar condições para o desenvolvimento de uma pessoa altamente criativa e talentosa. Nós podemos inclusive citar casos, na história da humanidade, de pessoas que apresentavam alguma deficiência mas conseguiram superar suas limitações físicas, demonstrando extrema criatividade, tais como: Ludwig Van Beethoven (um dos maiores músicos eruditos de todos os tempos, que adquiriu surdez em determinada etapa de sua vida, mas apesar do defeito conseguia compor melodias belíssimas); Hellen Keller (escritora americana, cega, surda e muda, que recebeu instrução superior e que, mesmo com as limitações sensoriais, se doutorou em Filosofia), entre outros. Dessa forma, "a tese central da defectologia é a seguinte: todo defeito (deficiência) cria os estímulos para elaborar uma compensação" 112 .

Devemos ressaltar, no entanto, que a compensação só ocorre nas funções psicológicas superiores, que são mecanismos psicológicos sofisticados como a consciência, atenção voluntária, memória lógica etc. Esses mecanismos, que emergem das relações sociais e se formam durante o período histórico de desenvolvimento da humanidade não devem sua origem à evolução biológica que formou o biótipo de ser humano, mas sim ao seu desenvolvimento histórico como ser social. Só no processo da vida social coletiva é que se elaboram e se desenvolvem todas as formas superiores da atividade intelectual própria do homem. O desenvolvimento das funções psíquicas superiores, tanto na filogênese como na ontogênese, tem sua origem na história e na cultura.

\footnotetext{
111 VIGOTSKI, 2012.p. op cit., 14. 112 Id, Ibid, p. 24.
} 
Vygotski entende que uma deficiência representa uma limitação, mas não necessariamente uma incapacidade. $O$ indivíduo que traz em si uma deficiência busca novas formas, novos caminhos para se apropriar da cultura por meio das intensas trocas que se dão no meio social, singularizando o seu desenvolvimento. A esses caminhos de desvios Vygotski dá o nome de caminhos isotrópicos (iguallugar), isto é, caminhos que conduzem ao mesmo objetivo ou ao mesmo lugar, por meio de outro mecanismo ou forma. ${ }^{113}$

Os caminhos isotrópicos são a prova de que o desenvolvimento complicado por um impedimento intelectual é qualitativamente distinto, acontecendo de modo muito peculiar e diferenciado daquele considerado padrão, ou seja, os processos do desenvolvimento infantil apresentam uma enorme diversidade de formas.

Nessa perspectiva, o objetivo de estudo da defectologia é a reação do organismo e da personalidade da criança com relação a sua deficiência.

Nesse sentido, o processo compensatório nem sempre é buscado e alcançado (ele pode ou não acontecer), ou seja, ele não apresenta um significado universal para qualquer desenvolvimento: "o mais importante é que junto com o defeito orgânico estão dadas as forças, as tendências a superá-lo ou nivelá-lo.” 114

Crer que qualquer impedimento será sempre compensado é tão ingênuo como pensar que o processo educacional é a mera transmissão de conhecimentos ou que o aluno é uma tábula rasa. $\mathrm{O}$ desenvolvimento dos caminhos isotrópicos se constitui em um processo consideravelmente difícil, por isso é muito importante que eles sejam estimulados. É importante que a educação das crianças com deficiência intelectual se oriente para a plena valorização social e que sejam consideradas as possibilidades compensatórias dessas crianças para superar os seus impedimentos, pois essas podem contribuir em primeiro plano para o processo de aprendizagem.

$\mathrm{O}$ professor, em seu processo de educação do aluno com DI, não deve se ater à insuficiência em si, ao déficit, ao impedimento cognitivo em si, mas à reação que nasce da personalidade da criança frente a sua deficiência, durante o seu processo de desenvolvimento, em resposta às dificuldades.

É necessário que esse professor leve em consideração as particularidades, ou seja, as peculiaridades do desenvolvimento de uma criança com deficiência. Uma criança com deficiência também pode obter êxito em seu processo educacional, porém de modo distinto,

\footnotetext{
113 VIGOTSKI, 2012, op. cit.

114 Id., Ibid.,
} 
por caminhos distintos, com meios distintos. É importante conhecer as peculiaridades do desenvolvimento atípico para realizar o trabalho pedagógico. $\mathrm{O}$ foco da ação pedagógica, assim, deixa de apontar as possíveis falhas do aluno e começa a focalizar as possíveis falhas nas situações de aprendizagem, preocupando-se com a qualidade das relações que estão sendo estabelecidas nos processos de ensino-aprendizagem.

Vygotski se opunha a uma pedagogia terapêutica, centrada no déficit orgânico e de orientação individualista. Para ele, a educação deveria se concentrar nas possibilidades de superação e compensação social da deficiência, logo, os problemas da educação de crianças com deficiência só poderiam ser resolvidos como problemas da pedagogia social, e a educação deveria ser direcionada para a compensação social. Assim, anos antes de se falar em inclusão escolar, ele já enfatizava que o processo educacional deveria ser capaz de realizar a promoção social da pessoa. Dessa forma, a análise da deficiência não deve partir do déficit orgânico ou cognitivo em si, mas do ambiente social.

O impedimento cognitivo ou sensorial se realiza como um desvio do tipo social normal de homem, isto é, como um desvio social, podendo provocar o declínio da posição social da criança. A deficiência é, pois, um valor socialmente instituído. Deficiente, portanto, é um nome que se dá às pessoas que possuem uma deficiência (defeito no dizer de Vigotsky) e que estão exiladas de alguma forma, e em algum grau, do convívio social.

Assim, Vygotski redimensiona a questão da deficiência da esfera médica/biológica para a esfera social pois para ele a deficiência não atua de forma direta, mas sim de forma indireta no desenvolvimento da criança, por meio das consequências sociais que acarreta. Observe-se, a esse respeito, o seu comentário:

[...] O que decide o destino da pessoa, em última instância, não é o defeito em si, mas sim suas consequências sociais, sua realização psicossocial. Os processos de compensação tampouco estão orientados para completar diretamente o defeito, o que na maior parte das vezes é impossível, mas simsuperar as dificuldades que o defeito cria $^{115}$

Windiz B. Ferreira, em artigo no livro "Inclusão x Exclusão no Brasil: Reflexões sobrea formação do Docente", a partir de sua experiência acompanhando por vários anos o movimento internacional e nacional da educação inclusiva, principalmente nas escolas, diz que há uma ênfase no papel crucial do professor no processo de desenvolvimento de escolas para todos e de promoção da inclusão, notadamente no combate à exclusão educacional de 
grupos vulneráveis, como é o caso das crianças com deficiência intelectual. Para o referido autor, espera-se que o professor, nos dias de hoje, seja capaz de compreender e praticar o acolhimento à diversidade e esteja aberto a práticas inovadoras na sala de aula. E este docente deve adquirir conhecimentos sobre como conhecer as características individuais de cada um aluno, como as habilidades, necessidades educacionais especiais, interesses, experiências, etc. 116

Jairo Werner Junior, em artigo "A Medicalização da Vida do Deficiente Como Barreira para a Inclusão Social", refere-se a uma pesquisa realizada com alunos do ensino especial, onde verificou-se que uma das principais barreiras à inclusão escolar reside na utilização de critérios avaliativos e classificatórios centrados na deficiência em si que fragmentam o aluno para "viabilizar" seu enquadramento em tipologias abstratas ou categoria "puras", a partir do núcleo primário de sua deficiência. A análise crítica com relação a essa postura encontra-se em trecho do relatório da pesquisa, como descrito a seguir:

\begin{abstract}
O aluno deficiente, como todo ser humano, possui natureza complexa, razão pela qual não pode ser tomado, interpretado, a partir do núcleo primário de sua deficiência (seja física, mental ou sensorial), pois estão em jogo, não só seu comprometimento orgânico, mas sua representação, sua subjetividade, seus comportamentos, suas habilidades e seus conhecimentos já construídos e a serem construídos. E estes elementos não decorrem, mecanicamente, do tipo de deficiência. Ao contrário, são construídos socialmente. $\mathrm{O}$ aluno deficiente traz em si tanto a marca de seu problema quanto a do meio cultural que o constitui [...]. $\mathrm{O}$ organismo humano deixa de pertencer ao meio natural, tornando-se parte integrante de um determinado meio sociocultural. Assim, a consciência emerge na e pela cultura. 117
\end{abstract}

Assim, para Werner, reportando-se a teoria de Vigotsky, a deficiência é coisificada, e a consequência do diagnóstico, orientado somente para a "falta" e para o "não", é o estabelecimento de limites, a priori, para o desenvolvimento do sujeito. Daí resultam metas negativas na esfera social e educacional. Em vez disso, a avaliação diagnóstica deveria propiciar o conhecimento, reverter as metas "minimalistas" e construir condições sociais de superação e a co-construção de novos conhecimentos e habilidades ${ }^{118}$.

\footnotetext{
116 FERREIRA, W. B. Inclusão x Exclusão no Brasil: reflexões sobre a formação docente dez anos após Salamanca. In: RODRIGUES, D. (Org.). Inclusão e Educação: doze olhares sobre a Educação Inclusiva. São Paulo: Summus Ed., 2006

117 WERNER JÚNIOR, Jairo. Universidade Estadual do Rio de Janeiro A medicalização da vida do deficiente como barreira para a inclusão social. In: SEMINÁRIO DA PÓS-GRADUAÇÃO E PESQUISA DE ENGENHARIA (COPPE), 2015, Rio de Janeiro. Anais eletrônicos... Rio de Janeiro: COPPE, 2015.
}

118 Id., Ibid., 
Diante disso, para Werner, muitos profissionais que trabalham na política da inclusão social das pessoas com deficiência buscam, incessantemente, o apoio de diagnósticos e classificações como instrumentos fundamentais, e este fato fica delineado na dependência do educador às avaliações médicas, neuropsicológicas, em que ele procura referência (diagnóstico médico, teste de QI, nível de atenção) para planejar o processo pedagógico, que se torna cada vez mais centrado na deficiência do aluno que no processo de interação social. Não se trata aqui de incompetência do professor, mas da incorporação passiva, porém efetiva, de concepções relacionadas à medicalização da vida, aplicadas à educação, contrariando os ensinamentos de Vigotsky e da educação inclusiva efetiva ${ }^{119}$.

Vemos então que a deficiência em si mesmo não atua isoladamente e sim de acordo com as exigências sociais. E essas exigências sociais da deficiência é que vão definindo ou determinando socialmente a construção da deficiência, confirmado, deste modo que é um fenômeno socialmente produzido e mantido com base em interpretações que adotam um padrão como referência e que estabelecem desvantagens, rótulos e estigmas para as pessoas que possuem um impedimento intelectual.

Nos reportando a Boaventura de Souza Santos ${ }^{120}$, quando explana sobre a exclusão, vemos que a noção de deficiência decorre de uma leitura social e, portanto, se constitui em um fenômeno social. Em consequência, é estabelecida uma situação de exclusão, de negação do outro que não corresponde às expectativas sociais.

Assim, o que determina a deficiência não é o impedimento intelectual, sensorial ou físico em si, mas o impacto social provocado pela presença desse impedimento. Existe uma espécie de construção social da deficiência provocada por expectativas sociais que podem instituir uma pessoa com impedimento cognitivo como uma pessoa incapaz e provocar o seu exilio relacional e o seu desenraizamento. Por esse prisma, a instituição do conceito de deficiência se constitui como um preconceito.

No entanto, uma pessoa com impedimento intelectual ou sensorial não é necessariamente uma pessoa incapaz. Quando não excluídas da vida social e quando lhes são

\footnotetext{
119 Id., Ibid.,

120 SANTOS, Boaventura de Sousa. A gramática do tempo: para uma nova cultura política. 3. ed. São. Paulo: Cortez, 2010. p. 296-298.
} 
dirigidos esforços efetivos de ensinar, com a busca de meios mediacionais especiais, essas pessoas manifestam imensas possibilidades de aprender e de se desenvolver. ${ }^{121}$

Apesar das barreiras sociais que forjam o fenômeno social da deficiência, a criança que possui um impedimento, com a ajuda de uma educação voltada para as peculiaridades dos educandos, pode romper com o quadro de descrédito estabelecido e mantido pela sociedade em relação à sua aprendizagem e ao seu desenvolvimento. Dito de outro modo, a educação não deve apenas adaptar-se ao impedimento dessa criança, mas também lutar contra ele e superá-lo. Então, o impedimento passa a ser visto como um desafio que se apresenta à pessoa que o manifesta e às pessoas que participam de sua educação.

Sobre as bases dessa visão social da deficiência, Vygotski rejeita a idéia de que as crianças que possuem um impedimento sejam incapazes de aprender e de se desenvolver. Para ele, os processos de desenvolvimento infantil apresentam uma enorme diversidade de formas, uma quantidade quase ilimitada de tipos diferentes. Ainda segundo Vygotski, cabe à ciência o estudo das leis dessa diversidade e o estabelecimento dos ciclos e das metamorfoses do desenvolvimento ${ }^{122}$.

Assim, considerando que o processo de desenvolvimento psicológico acontece de forma diferente e particularizada, duvida-se das bases científicas do conceito hegemônico e amplamente difundido de deficiência associado com o déficit. A esse respeito são relevantes as notas de Vygotski:

[...] Sobre as bases de uma concepção meramente quantitativa de deficiência infantil, só é possível uma "anarquia pedagógica", [...] só é possível um resumo eclético e fragmentado de dados e procedimentos empíricos, mas não um sistema de conhecimento científico ${ }^{123}$.

Nesse sentido, entendemos que a ideia de deficiência foi estabelecida segundo critérios puramente quantitativos, sem nenhuma análise mais profunda sobre as peculiaridades do desenvolvimento da criança com impedimento cognitivo. Assim, a deficiência constitui-se como uma barreira que implica práticas atitudinais de exclusão e que, consequentemente, dificulta a realização do processo de inclusão escolar.

Dessa forma, também não podemos deixar de destacar que o uso da ciência para a

\footnotetext{
121 TUNES, E.; PIANTINO, L. D. Cadê a síndrome de Down que estava aqui? O gato comeu... O programa da Lurdinha.Campinas: Autores Associados, 2001.

122 VIGOTSKI, 2012, op cit.

${ }^{123}$ VIGOTSKI, 2012, op. cit.
} 
legitimação de práticas de exclusão em relação às pessoas com deficiência, não se constitui como um fato novo, pois é só lembrar que a eugenia foi adotada como método científico pelos nazistas nos meados do século 20 quando do holocausto.

Tunes e Bartholo traçam uma breve trajetória histórica de diferentes concepções científicas acerca do desenvolvimento humano na Psicologia, caracterizando os principais pressupostos das visões naturalistas e histórico-culturais e destacando seus antagonismos. A autora descreve como a psicologia do desenvolvimento sofreu fortes influências das idéias postuladas por representantes do determinismo biológico, os quais acreditavam que o psiquismo humano era biologicamente determinado e que as diferenças sociais e econômicas existentes entre os grupos humanos (raça, classe, sexo) tinham origens biológicas. ${ }^{124}$

Assim, o argumento científico apoiado em bases biológicas pode ser uma poderosa arma para justificar injustiças sociais, práticas de exclusão e, consequentemente, para a imposição de limites em relação ao desenvolvimento de pessoas consideradas socialmente deficientes. É com esse olhar histórico que podemos analisar muitas de nossas práticas cotidianas e de nossas idéias acerca da deficiência. A este respeito, observe-se o seguinte comentário de Tunes ${ }^{125}$ :

[...] Queiramos ou não, tenhamos ou não consciência dos pressupostos que assumimos em nossa atuação, nossas idéias e pensamentos refletem o espírito do tempo - o zeitgheist - e a nossa época ainda é a do império do naturalismo. Se ficarmos atentos ao que ocorre ao nosso redor, se focalizarmos, especialmente, alguns fragmentos, muito frequentes, de nossas falas, iremos identificar com facilidade a presença de concepções naturalistas.

Assim, influenciadas e justificadas por proposições científicas, cujo foco de investigação se concentra nos aspectos biológicos das pessoas com impedimento, emergem as práticas de exclusão em relação às pessoas instituídas socialmente como deficientes. $\mathrm{O}$ impedimento passa a ser visto como uma barreira social intransponível, cuja presença corresponde à instituição direta da deficiência. Justifica-se assim o exclusão social, realizado e legitimado pelo preconceito.

Portanto, ao avaliarmos o alcance da influência exercida pela cultura e pela ciência nas

124 TUNES, Elizabeth; BARTHOLO, Roberto dos S. J. O trabalho pedagógico na escola inclusiva. In: CONGRESSO NORTE-NORDESTE DE PSICOLOGIA, 3. 2003. João Pessoa. Anais ... João Pessoa: UFPB, 2003, p.10-12.

125 TUNES, Elizabeth. Preconceito, inclusão e deficiência - o preconceito no limiar da deficiência. In: Org. por TUNES, Elizabeth Tunes; BARTHOLO, Roberto. Nos Limites da Ação: preconceito, inclusão e deficiência. São Carlos: EDUFCAR, 2002. p. 149. 
idéias sobre a deficiência ao longo dos tempos, podemos reconhecer que o preconceito não se trata de um conceito prévio, sem fundamentos o suficiente. Possuir conhecimento fundamentado não significa condição de possibilidade para se diminuir a presença do preconceito. Porém, o tipo de conhecimento pode ou não implicar em condições de possibilidade para o surgimento do preconceito, ou seja, pode ocasionar o descompromisso com o outro ou, inversamente, pode não se constituir como um impedimento para o acontecimento da relação uma pessoa e outra.

Acontece também que o tipo de conhecimento pode ou não implicar em condições de possibilidade para o aparecimento do preconceito da deficiência. Nesse aspecto, a maneira pela qual nos relacionamos com a questão da deficiência depende fundamentalmente do momento histórico, da visão de mundo e do tipo de conhecimento que permeiam, influenciam e orientam nossos comportamentos em dada situação. Então, os nossos encontros e desencontros são articulados em torno de nosso sistema de crenças, de nossos valores e até mesmo de conhecimentos científicos, culturalmente diluídos pelo senso comum. A história, a cultura e a ciência influenciam o que vemos e o modo como vemos.

Diante disso, o preconceito da deficiência não acontece de forma aleatória. Com base em uma visão de mundo enraizada em um sistema de crenças, preconceitos e até mesmo em teorias científicas, o individuo pode rotular, classificar e encaminhar o outro para um exilio relacional, no dizer de Tunes, da mesma forma que também pode optar pelo encontro autêntico.

Mas transpor a barreira da diversidade, não é tão simples assim. Não se pode fugir da grande dificuldade de se relacionar com uma pessoa que foge ao que nós supomos ser o padrão social. Sem perceber, acabamos "justificando" que muitos de nós não se sentem preparados para trabalhar com pessoas que possuem impedimentos intelectuais, pois, a partir de padrões biológicos impostos culturalmente no passado, refletimos em nossos atos padrões de referência que excluem o diferente:

[...] no âmbito da educação, principalmente no ambiente escolar, é muito comum ouvirmos as pessoas dizerem que não se sentem preparadas para atuar com as crianças e os jovens especiais. É verdade. De fato, não estamos preparados para isso. Se estivés semos, o nos so compromis so com essas crianças e jovens não se traduziria como um desafio. É desafio exatamente porque não sabemos como fazer. Temos que investigar, buscar, descobrir. Mas a questão a ser feita não é se estamos ou não preparados para isso. A pergunta é outra: queremos aceitar o desafio? (grifo da autora) ${ }^{126}$

126 TUNES; BARTHOLO, 2003, op. cit., p. 11. 
Vimos nas entrevistas referenciadas (e anexas a este texto) que a maioria dos professores da escola pesquisada atribuem à falta de preparo uma das principais condições de impossibilidade para se relacionar e atender os alunos com DI. Porém, o acontecimento de uma relação autêntica entre seres humanos que se reconhecem diferentes, não depende das formações e teorias pedagógicas, até porque, diante da diversidade, o preparo técnico não dá conta da complexidade humana, pois não existem fórmulas mágicas que revelem como agir com seres humanos.

Como em qualquer situação, antes de a pessoa se relacionar com outra pessoa, ela tem de decidir se está ou não aberta para um possível encontro, se deseja ou não conhecer o outro. Concordando com Tunes, o desafio de encontrar com o outro é uma decisão pessoal, mesmo sabendo que o outro signifique o desconhecido, o inusitado. Não há possibilidade de uma relação se não houver a aceitação do outro como ele é, se não houver reciprocidade de ambas as partes.

Muitos professores podem imaginar que trabalhar com pessoas com impedimentos intelectuais exige mais responsabilidade do que dar aulas para crianças sem impedimentos intelectuais, no entanto, eticamente não existe a possibilidade de escalonar em maior ou menor grau a responsabilidade de ensinar, a depender dos alunos. Se os professores são direcionados pela ética, a responsabilidade é a mesma, o compromisso é o mesmo, o encontro, sim, com cada pessoa é diferente.

Dessa forma, a idéia de diversidade deve ser refletida em todas as escolas. Não se pode simplesmente fechar os olhos e fingir que as crianças que possuem algum tipo de impedimento cognitivo não existem, pois as mesmas são também seres humanos, com sonhos, desejos, emoções, sentimentos e necessidades e, agora, embora alguns não aceitem, fazem parte da escola regular, ou seja, também são alunos como outro qualquer.

Nesse sentido, para que a exclusão escolar deixe ser uma prática efetiva, o processo educativo deve promover o respeito às diferenças humanas, desvelando e discutindo conceitos pejorativos, que não valorizam os alunos, mas que os exilam e os rotulam em sala de aula.

Sem essa reflexão, estaremos, como diz Tunes, realizando apenas uma exclusão disfarçada de inclusão, na qual os alunos tratados como deficientes intelectuais continuarão sendo vítimas do preconceito e do exílio relacional.

Para concluir este capítulo, e por acreditar que um processo educacional inclusivo de crianças com deficiência intelectual é possível, adiro ao Manifesto da Ilha do Fundão, proposto por estudiosos, profissionais e representantes de entidades públicas e privadas, 
reunidos na Ilha do Fundão, no Rio de Janeiro, Brasil, entre 16 e 19 de maio de 2005, que, diante do desafio de enfrentar essa grave exclusão factual de alunos com deficiência, realizaram o Seminário Nacional sobre preconceito, inclusão e deficiência, com apoio do Laboratório de Tecnologia e Desenvolvimento Social (LTDS), da Universidade Federal do Rio de Janeiro, e o Centro de Desenvolvimento Sustentável (CDS), da Universidade de Brasília, onde foi definido:

Sendo a vida humana relação, a ética nasce do entre dois. Não está no sujeito a primazia do ser, mas sim em nossa vulnerabilidade à alteridade. A vida ética é, assim, a experiência de limites e se nutre do exercício de virtudes. O propriamente humano é, então, resposta ao apelo de um outro, percebido em uma relação vinculante, a quem se reconhece e se acolhe em sua irredutível alteridade. A resposta ao apelo do outro é pessoale, portanto, intransferível.

O princípio dialógico pressupõe o encontro autêntico, face a face com o outro. Um falar com ele e não dele, por meio da generalidade e do anonimato dos conceitos. Dialogar é responder pessoalmente a um apelo que um Outro a mim endereçou. $\mathrm{O}$ dialógico é o fundamento do encontro entre pessoas.

O preconceito é, por definição, o já sabido pelo Eu, um saber prévio e independente a qualquer escuta interpes soal.

Tendo como fundamento o que se acaba de afirmar, declara-se o princípio basilar da inclusão social nos seguintes termos:

A inclusão social é um ato de responsabilidade pessoal, fundamentado na afirmação da irredutibilidade da pes soa e orientado para a pres ervação da alteridade ${ }^{127}$.

Deste princípio decorrem as seguintes proposições:

Proposição 1: a inclusão social afirma-se no campo da ética.

Proposição 2: a inclusão social é um ato de justiça.

Proposição 3: a inclusão é regida pelo princípio dialógico em que há o primado do encontro com a alteridade.

Proposição 4: a igualdade dos seres humanos deve estar sempre referida ao primado da alteridade.

Proposição 5: toda pessoa é soberana para recusar a submeter-se a condições que lhe as sinalem alguma desigualdade como ser humano enquanto tal.

Proposição 6: o preconceito é um modo de desresponsabilização pessoal, que serve como barreira para o ato relacional inclusivo e afirmativo da irredutibilidade da pessoa.

Proposição 7: a recusa ao acolhimento de uma pessoa em razão da afirmação de uma desigualdade humana presumida é um ato de preconceito.

Proposição 8: a identificação da pessoa pelo atributo da deficiência é um ato de preconceito $^{128}$.

Diante do princípio declarado e das proposições dele decorrentes, um programa de ação que vise à inclusão social deve priorizar:

1. o combate ao preconceito sob quaisquer formas, inclusive a de afirmação de

\footnotetext{
${ }^{127}$ UNIVERSIDADE FEDERAL DO RIO DE JANEIRO. Seminário COPPE. Rio de Janeiro, 2008. Anais eletrônicos.... Rio de Janeiro: UFRJ, 2008.p.46
}

128 UFRJ, 2008, op cit. 
bioidentidades;

2. o combate a formas segregadoras, discriminatórias e assistencialistas de educação, de acesso ao trabalho e às atividades culturais, artísticas, desportivas e sociais;

3. o combate a formas setorizadas de atividades educacionais, profissionais, culturais, artísticas, desportivas e sociais que imprimam nessas atividades um caráter social segregador e discriminatório;

4. o combate às formas de institucionalização que admitam, requeiram ou visem à padronização e hierarquização dos seres humanos sob a forma de bioidentidades;

5. a desobrigação do diagnóstico como forma de identificação e de atestado de bioidentidade para o aces so à educação, ao trabalho e ao lazer;

6. o incentivo ao desenvolvimento de novas tecnologias mediacionais que possibilitem o acesso a bens culturais da humanidade;

7. o incentivo à criação de alternativas educacionais, profissionais, artísticas e culturais fundamentadas na afirmação da diversidade de possibilidades dos seres humanos;

8. o incentivo a ações e movimentos comunitários que, exercidos com autonomia, visem à inserção social em atividade locais próprias;

9. o incentivo à criação de modalidades institucionais que se fundamentem na afirmação das possibilidades dos seres humanos;

10. o incentivo a modalidades de ação institucional desvinculadas da lógica produtiva e utilitarista, que se orientem para o exercício de valores humanos de convivência;

11. o incentivo a práticas sociais que assumam os valores humanos de convivência como primeira pauta;

12. o incentivo a práticas sociais instituidoras de condições que possibilitem a assunção de responsabilidades pess oais. ${ }^{129}$ 


\section{CONCLUSÃO}

Conclui-se , assim, esse estudo sabendo que a educação que queremos garantir a essas crianças com deficiência é a de uma política inclusiva, baseada normativa e primordialmente nos princípios e regras da Convenção sobre os Direitos das Pessoas com Deficiência, onde se reconheça os impedimentos e particularidades das crianças com deficiência intelectual, a partir de uma concepção complexa de igualdade baseada no liberalismo igualitário de Ronald Dworkin, e de uma prática pedagógica libertária e de autonomia, defendida por Paulo Freire, Maria Tereza Mantoan e Ivanilde Apoluceno, e que leve em conta a convivencialidade, defendida por Ivan Ilich, e a diversidade humana, para superar barreiras físicas e atitudinais e alcançar a cidadania plena.

Avaliamos que a escola pesquisada não está de fato, promovendo a educação normativamente assegurada, e sim a simples escolarização dos infantes com DI. Que necessita de melhor estrutura física e de pessoal, com garantia de acessibilidade arquitetônica e tecnológicas. E de pessoal, como professores e demais profissionais melhor capacitados e sensibilizados para receberem esses alunos com necessidades educacionais especiais. Algumas reformas físicas e melhorias de material pedagógico foram feitas no início deste ano de 2016, mas ainda são incipientes.

Uma outra importante constatação neste estudo, principalmente com a ação judicial que permitiu melhorias na escola Marta da Conceição, é de que o problema maior na garantia da educação dos infantes com deficiência está na política, no cumprimento das políticas públicas prescritas nas leis e programas estatais. Como dito antes, o Estado dá com uma mão, ao garantir os direitos formalmente, e retira com a outra, ao não os implementar por ação ou omissão dos órgãos responsáveis pela execução das normas.

A educação, assim como a saúde, inclui-se entre os direitos essenciais e fundamentais ao cidadão por força da Constituição Federal e dos princípios que regem os direitos humanos de segunda geração. O Supremo Tribunal Federal, como já demonstrado, ao afirmar em suas decisões a educação como direito fundamental e essencial ao ser humano, a coloca, para nosso estudo, como mínimo essencial para a dignidade e autonomia de crianças com deficiência intelectual, cuja ações tem que ser priorizadas pelo Estado e sociedade, sob pena de a comunidade que os representa provocar e obrigar a ação dos órgãos de defesa dos direitos das pessoas com deficiência, como o Ministério Público de zelar pelo seu cumprimento. 
Vimos, ainda, e com base nos estudos analisados de Lev Vigotski, em sua obra Fundamentos da Defectologia que a dificuldade na área educacional da criança com deficiência intelectual não está na sua deficiência, mas na sua relação com a cultura que não a aceita como ela é, que seu processo de desenvolvimento está condicionado socialmente, não biologicamente. E que uma deficiência intelectual na escola representa um impedimento, mas não necessariamente uma incapacidade, pois a criança que tem uma deficiência busca novas formas, novos caminhos para se apropriar da cultura por meio de intensas trocas ou compensações que se dão no meio social, junto com os demais alunos, com ou sem deficiência, singularizando o seu desenvolvimento.

E, desta forma, se oportunizarmos, por meio de outros caminhos, alternativas aos préestabelecidos pelo sistema, (que Vigotski chama de caminhos isotrópicos) mas que conduzem ao mesmo objetivo ou ao mesmo lugar para o desenvolvimento, a criança com deficiência intelectual alcançará sua meta social, neste caso a educação como forma de autonomia.

Também percebe-se, comparando essa dissertação com outra pesquisa em educação, a de Neide Aparecida Lopes ${ }^{130}$, e ainda o analisado neste estudo com base no sustentado por Elizabeth Tunes, Maria Teresa Mantan e Ivanilde Apoluceno, em relação as entrevistas de boa parte dos professores na escola pesquisada e que atendem alunos com deficiência intelectual, que se revelou uma contradição no discurso desses professores, pois considerando a normatividade presente e a repercussão social que a inclusão provoca, esses professores não se revelam desfavoráveis a essa ideia, mas sua prática no cotidiano escolar evidencia sua resistência, com práticas integracionistas ultrapassadas que reforçam a exclusão. Ficou patente que utilizam a desculpa do despreparo técnico, e da falta de formação específica, como justificativa para sua resistência em aceitar o aluno com deficiência intelectual na sala de aula comum.

Verifica-se, ainda, que uma capacitação técnica melhor, aliada a boas condições estruturais e pedagógicas na escola, é importante para um melhor desempenho desses docentes, mas a ausência desse preparo e de melhores condições estruturais não pode se transformar em impeditivo para a aceitação do compromisso com o outro, com o diferente, pois existem outras esferas da vida que definem isso, esferas que ultrapassam o espaço da dimensão técnica do conhecimento. Os doze pontos mencionados, no capítulo anterior, no Manifesto da Ilha do Fundão, proposto por estudiosos, profissionais e representantes de

130 LOPES, Neide Aparecida. Deficiência e inclusão escolar, um estudo sobre representações sociais. Dissertação de Mestrado. Brasília: UNB, 2005. 
entidades públicas e privadas, reunidos na Ilha do Fundão, no Rio de Janeiro, Brasil, entre 16 e 19 de maio de 2005 são medidas que também precisam ser observadas para uma efetiva inclusão pedagógica dessas crianças com impedimentos cognitivos.

Outra questão relevante constatada neste estudo e embasado nos estudos de Ivan Ilich $^{\mathbf{1 3 1}}$, é que as nossas escolas públicas atualmente estão submetidas em um alto grau às imposições institucionais e burocráticas de uma prática política educacional que não atende os ditames constitucionais e legais, tendo como objetivo de promover a escolarização de todos os alunos dentro de um padrão pré-estabelecido pelo sistema educacional que vivemos, e com preocupação com a quantidade de alunos a atender, e não com a qualidade desse ensino. A escola pública, como se encontra hoje, não garante a aceitação do aluno como ele é, e tenta transformá-lo em um aluno idealizado nos manuais do mercado de trabalho, não levando em conta sua diversidade e peculiaridade como ser humano. Precisamos repensar a escola contemporânea, para que ela possa possibilitar condições mínimas de dignidade e autonomia às crianças com deficiência intelectual, a fim que elas participem na construção da vida social; e possam, junto com os demais que a constroem, desenvolver suas habilidades, capacidades e exercício de seus direitos.

E, finalmente, importante constatar que começa a surgir, na comunidade que habita a ilha de Cotijuba, um movimento ético-crítico que busca uma prática libertadora e de autonomia, observada nos familiares e alguns profissionais da escola que denunciaram as condições precárias da escola Marta da Conceição as autoridades e aos setores da imprensa, inclusive em passeatas nas ruas, e assim, conseguiram que o Estado, inerte há anos, começasse uma reforma física na escola, mesmo que compelido judicialmente. E isso dá uma expectativa de que algo possa mudar em benefício dos alunos com deficiência intelectual da Escola Marta da Conceição na busca pela igualdade e dignidade que garantirão o reconhecimento de sua cidadania num País complexo e contraditório em suas políticas públicas como o nosso.

${ }^{131}$ ILICH, Ivan. Sociedade sem Escolas. Petrópolis: Vozes, 1979. 


\section{REFERÊNCIAS}

ALFAIA, Maria Roseline Rodrigues. Professora da EEEF Marta Conceição. Informações Verbais. Belém, 2015. Entrevista concedida ao autor desta pesquisa.

ALVES, Rubens Valtecides. Deficiente físico: novas dimensões da proteção ao trabalhador. São Paulo: LTR, 1992.

BRANCO, Paulo Gustavo; MENDES, Gilmar Ferreira. Curso de Direito Constitucional. $10^{\mathrm{a} e d . ~ S a ̃ o ~ P a u l o: ~ S a r a i v a, ~} 2015$.

BRASIL. Constituição (1988). Constituição da República Federativa do Brasil. Promulgada em 5 de outubro de 1988. Brasilia, DF: Senado Federal, 1988.

BRASIL. Congresso Nacional. Decreto legislativo $n^{\circ} 186$, de 09 de julho de 2008. Aprova o texto da Convenção sobre os Direitos das Pessoas com Deficiência e de seu Protocolo Facultativo, assinados em Nova Iorque, em 30 de março de 2007. Diário Oficial [da] República Federativa do Brasil. Brasilia, 10 de julho de 2008. Disponível em: http://www.justicaeleitoral.jus.br/arquivos/tre-al-decreto-legislativo-186-2008. Acesso em: 21.12.2012.

BRASIL. Decretos e Leis. Lei $\mathrm{n}^{\circ}$ 5.692, de 11 de agosto de 1971. Fixa Diretrizes e Bases para o ensino de $1^{\circ}$ e $2^{\circ}$ graus, e dá outras providências. Diário Oficial [da] República Federativa do Brasil. Brasília, 12 de agosto de 1971. Disponível em: https //www.planalto.gov.br/ccivil_03/leis/L5692.htm. Acesso em: 28.08.2014.

BRASIL. Decretos e Leis. Lei $\mathrm{n}^{\mathrm{o}}$ 8.069, de 13 de julho de 1990. Dispõe sobre o Estatuto da Criança e do Adolescente e dá outras providências. Diário Oficial [da] República Federativa do Brasil. Brasilia, 14 de julho de 1990. Disponível em:

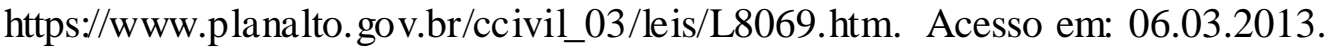

BRASIL. Decretos e Leis. Lei n ${ }^{\circ}$ 9.394, de 20 de dezembro de 1996. Estabelece as diretrizes e bases da educação nacional. Diário Oficial [da] República Federativa do Brasil. Brasilia, 21 de dezembro de 1996. Disponível em: https://www.planalto.gov.br/ccivil_03/Leis/L9394.htm. Acesso em: 21.12.2012.

BRASIL. Decretos e Leis. Decreto $\mathrm{n}^{\circ}$ 7.612, de 17 de novembro de 2011. Institui o Plano Nacional dos Direitos da Pessoa com Deficiência - Plano Viver sem Limite. Diário Oficial [da] República Federativa do Brasil. Brasilia, 18 de novembro de 2011. Disponível em: http://www.planalto.gov.br/CCIVIL_03/_Ato2011-2014/2011/Decreto/D7612.htm. Acesso em: 28.08.2014.

BRASIL. Decretos e Leis. Lei no 10.172, de 9 de janeiro de 2001. Aprova o Plano Nacional de Educação e dá outras providências. Diário Oficial [da] República Federativa do Brasil. Brasilia, 10 de janeiro de 2001. Disponível em: http://www.planalto.gov.br/ccivil_03/leis/LEIS_2001/L10172.htm. Acesso em: 21.12.2012.

BRASIL. Decretos e Leis. Decreto no 6.949, de 25 de agosto de 2009. Promulga a Convenção Internacional sobre os Direitos das Pessoas com Deficiência e seu Protocolo Facultativo, assinados em Nova York, em 30 de março de 2007. Diário Oficial [da] República Federativa 
do Brasil. Brasilia, 26 de agosto de 2009. Disponível em: http://www.planalto.gov.br/ccivil_03/_Ato2007-2010/2009/Decreto/D6949.htm. Acesso em: 21.12.2012.

BRASIL. Decretos e Leis. Lei $n^{\circ} 13.005$, de 25 de junho de 2014. Aprova o Plano Nacional de Educação - PNE e dá outras providências. Diário Oficial [da] República Federativa do Brasil. Brasilia, 26 de junho de 2014. Disponível em:

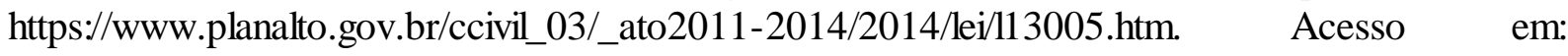
28.08.2014.

BRASIL. Decretos e Leis. Lei ${ }^{\circ}$ 13.146, de 6 de julho de 2015. Institui a Lei Brasileira de Inclusão da Pessoa com Deficiência (Estatuto da Pessoa com Deficiência). Diário Oficial [da] República Federativa do Brasil. Brasilia, 07 de julho de 2015. Disponível em: http://www.planalto.gov.br/ccivil_03/_ato2015-2018/2015/Lei/L13146.htm. Acesso em: 28.08.2015.

BRASIL. Ministério da Educação. Política Nacional de Educação Especial na Perspectiva da Educação Inclusiva. 2008. Disponível em: http://portal.mec.gov.br/arquivos/pdf/politica

educespecial.pdf. Acessado em 04.02.2015.

BRASIL. Ministério da Educação. Secretaria de Educação Especial. Política Nacional de Educação Especial. Brasilia: MEC/SEESP, 1994.

BRASIL. Ministério da Educação. Câmara de Educação Básica. Resolução $n^{o} 4$, de 2 de outubro de 2009. Institui Diretrizes Operacionais para o Atendimento Educacional Especializado na Educação Básica, modalidade Educação Especial. Disponível em: http://www.abiee.org.br/doc/Resolu\%E7\%E3o\%204\%20DE\%2002\%20out\%202009\%20ED UCA\%C7\%C3O\%20ESPECIAL\%20rceb004_09.pdf. Acesso em: 01.04.2013.

Resolução CNE/CEB $n^{o}$ 2, de 11 de setembro de 2001. Institui Diretrizes Nacionais para a Educação Especial na Educação Básica. 2001. Disponível em: http://portal.mec.gov.br/cne/arquivos/pdf/CEB0201.pdf. Acesso em: 09.11.2012.

BRASIL. Ministério Público Federal. O Acesso de alunos com deficiência às escolas e classes comuns da rede regular. 2. ed. rev. e atual. Brasilia: Procuradoria Federal dos Direitos do Cidadão, 2004.

BRASIL. Secretaria de Direitos Humanos Secretaria Nacional de Promoção dos Direitos da Pessoa com Deficiência. Convenção sobre os Direitos das Pessoas com Deficiência. 4. ed., rev. e atual. Brasîlia : Secretaria de Direitos Humanos, Secretaria Nacional de Promoção dos Direitos da Pessoa com Deficiência, 2012. Disponível em: http://www.pessoacomdeficiencia.gov.br/app/sites/default/files/publicacoes/convencaopessoa scomdeficiencia.pdf. Acesso em: 25.01.2013.

CAMPOY CERVERA I., Los derechos de las personas con discapacidad. Perspectivas sociales, políticas, jurídicas y filosóficas. Madrid: Dykinson, 2004.

CARDOSO, Ana Marcia Nunes. O liberalismo em Dworkin: uma releitura dos princípios liberais (Dissertação de Mestrado) UFSC. 2004. Acessado em 30.10.2016 em http://repositorio.ufsc.br/xmlui/handle/123456789/88135. 
CARNEIRO, M. A. LDB fácil: leitura crítico-compreensiva artigo a artigo. 23. ed. Petrópolis: Vozes, 2015.

CARNEIRO, M. A. PNE: Fios e desafios do Plano Nacional de Educação. Brasilia DF: Ed, Direcional, 2015.

CARDOSO, Ana Marcia Nunes. O Liberalismo em Dworkin: uma releitura dos princípios liberais. 2004. Dissertação (Mestrado em Direito) - Universidade Federal de Santa Catarina, 2004.

CARVALHO, R. E. Educação inclusiva: com os pingos nos “is". Porto Alegre: Mediação, 2004.

CASTRO, C. D. M. A invencível fraqueza do ensino fundamental. In: VELOSO, Fernando et al. (Ed.). Educação básica no Brasil: construindo o país do futuro. Rio de Janeiro: Campus; Elsevier, 2009. p. 157-168.

CAVALCANTE, A.V. O preconceito da deficiência no processo de inclusão escolar. 2004. 74 f. Dissertação (Mestrado em Educação) - Faculdade de Educação, Universidade de Brasilia, Brasilia. 2004.

COMPARATO, Fábio Konder. A afirmação histórica dos direitos humanos. 5. ed. São Paulo: Saraiva, 2007.

CORREIA, L. M., Alunos com Necessidades Educativas Especiais nas Classes Regulares. Porto: Porto editora, 1999.

COUTINHO, Joel da Silva, aluno da EEEFM Marta Conceição que apresenta DI. Informações Verbais. Belém, 2015. Entrevista concedida ao autor desta pesquisa.

DEWEY, John. Democracia e Educação. Trad. Godofredo Rangel e Anísio Teixeira. 4. ed. São Paulo: Comp. Ed. Nacional, 1979.

DWORKIN, Ronald. A virtude soberana: a teoria e a prática da igualdade. São Paulo: Martins Fontes, 2005.

DWORKIN, Ronald. O Império do Direito. São Paulo: Martins Fontes, 2010.

DWORKIN, Ronald, Justiça para Ouriços, trad. Pedro Elói Duarte. Coimbra: Almedina, 2012.

EDUCAÇÃO: escola estadual é visão do purgatório. Diário do Pará on line. 23.11.2014. Caderno Atualidades. Disponível em: http://www.diarioonline.com.br/noticiasinterna.php?nIdNoticia=310135\&idrand=156. Acesso em: 26.08.2015.

FAVERO, Eugênia Augusta Gonzaga. O direito das pessoas com deficiência de acesso à educação. In: ARAÚJO, Luiz Alberto David (Coord.); PRADO, Adriana Romeiro de Almeida et al. Defesa dos direitos das pessoas portadoras de deficiência. São Paulo: RT, 2006. p. 152174. 
FELÍCIO, Fabiana. O Ensino fundamental: Desafios desde a alfabetização até a transição para o ensino médio. In: VELOSO, Fernando (org.) et al. Educação Básica no Brasil. Rio de Janeiro: Elsevier, 2009.

FELÍCIO, Fabiana; VASCONCELOS, Lígia. O Efeito da educação infantil sobre o desempenho escolar medido em exames padronizados. In: ENCONTRO NACIONAL DE ECONOMIA, 35., 2007, Recife. Anais Eletrônicos... Recife: Anpec, 2007. 1 CD-ROM.

FELIPPE, Marcio Sotelo. Direito e Moral. 1ª ed. São Paulo: Estúdio Editores, 2014. v. 1. 77p

FERRAZ, Carolina Valença; LEITE, Glauber Salomão; NEWTON, Paulla Christianne da Costa (coords.). Cidadania Plural e diversidade: a construção do princípio fundamental da igualdade nas diferenças. $1^{\mathrm{a}}$ ed. São Paulo: Editora Verbatim, 2012.

FERREIRA, W. B. Inclusão x Exclusão no Brasil: reflexões sobre a formação docente dez anos após Salamanca. In: RODRIGUES, D. (Org.). Inclusão e Educação: doze olhares sobre a Educação Inclusiva. São Paulo: Summus Ed., 2006

FREIRE, Paulo. Pedagogia do Oprimido. Rio de Janeiro: Paz e Terra, 2005.

GOMES, Joaquim Barbosa. Ação Afirmativa e Princípio Constitucional da Igualdade: O Direito como instrumento de transformação social. A experiência dos EUA. Rio de Janeiro: Renovar, 2001.

GUEDES, Jefferson Carús. Igualdade e desigualdade: introdução conceitual, normativa e histórica dos princípios. São Paulo: Revista dos Tribunais, 2014.

GUERRA FILHO, Willis S. Processo constitucional e direitos fundamentais. São Paulo : Celso Bastos Ed., 1999.

HABERMAS, Jürgen. Direito e Democracia, entre facticidade e validade. Tradução de Flávio Beno Siebeneichler. Rio de Janeiro: Tempo Brasileiro, 2012. V. 1.

ILLICH, Ivan. A Convivencialidade. Trad. Arsênio Mota. São Paulo: Publ. Europa-América, 1973.

ILICH, Ivan. Sociedade sem Escolas. São Paulo: Vozes, 1979.

ISHIDA, Valter Kenji. Estatuto da criança e do adolescente: doutrina e jurisprudência. 15 ed. São Paulo: Atlas, 2014.

JANUZZI, Gilberta de Martino. A educação do deficiente no Brasil: dos primórdios ao inicio do século XXI. 2. ed. Campinas-SP: Autores Associados, 2006.

KASSAR, Monica de Carvalho Magalhães. Deficiência Múltipla e Educação no Brasil. São Paulo: Autores Associados, 1999.

LANNA JUNIOR, Mário Cleber Martins. História do Movimento Político das Pessoas com Deficiência. Brasilia: DF: Secretaria Nacional de Promoção dos Direitos das Pessoas com Deficiência, 2010. 
LOPES, N.A. Deficiência e Inclusão Escolar: um estudo sobre Representações Sociais. 2005. Dissertação (Mestrado em Educação) - Faculdade de Educação, Universidade de Brasilia, Brasîlia. 2005.

MANTOAN, Maria Tereza Eglér. Inclusão Escolar: O que é? Por quê? Como Fazer?. São Paulo: Moderna, 2003.

MANTOAN, Maria Tereza Eglér, PRIETO, Rosângela Gavioli. Inclusão Escolar: Pontos e contrapontos. 3. ed. São Paulo: Summus, 2006.

MAZZOTTA, M. J. S. Educação Especial no Brasil: História e Políticas Públicas. São Paulo: Cortez, 2005.

MACIEL, Irene, Coordenadora da Unidade Técnica de Educação Especial de Icoaraci. Informações Verbais. Belém, 2015. Entrevista concedida ao autor desta pesquisa.

MENDES, Gilmar; BRANCO, Paulo Gonet. Curso de Direito Constitucional. São Paulo: Saraiva, 2015, p.650-651.

MENDONÇA, Ana Abadia dos Santos. Escolarização de crianças com deficiência intelectual nos anos iniciais do ensino fundamental. 2014. 171 f. Dissertação (mestrado) - Programa de Mestrado em Educação, Universidade de Uberaba, 2014. Orientador: Prof. Dr. Wenceslau Gonçalves Neto.

MELO, Celso, Rel. ADPF - Políticas Públicas - Intervenção Judicial - "Reserva do Possível" (Transcrições) ADPF 45 MC/DF. Diário Oficial [da] República Federativa do Brasil. Brasilia,

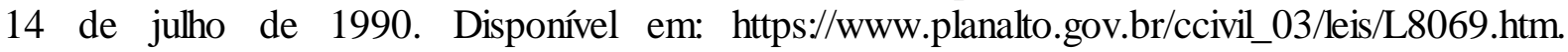
Acesso em: 04.05.2014.

MULleR, Pierre; SUREL, Yves. A Análise das Políticas Públicas. Traduzido por: Agemir Bavaresco, Alceu R. Ferraro. Pelotas: Educat, 2002. 156p. (Coleção Desenvolvimento Social 3).

NAÇÕES UNIDAS. Declaração de Salamanca: Sobre Princípios, Políticas e Práticas na Área das Necessidades Educativas Especiais. 1994. Disponível em: http://portal.mec.gov.br/seesp/arquivos/pdf/salamanca.pdf. Acesso em: 02.02.2013.

OLIVEIRA, Ivanilde Apoluceno. Saberes, imaginários e representações na educação especial. 2. ed. Petrópolis: Ed. Vozes, 2004.

PALANGANA, Isilda Campaner. Desenvolvimento e aprendizagem em Piaget e Vygotsky: a relevância do social. $3^{\text {a }}$ ed. São Paulo: Summus, 2001.

PARÁ. Conselho Estadual de Cultura. Resolução CEE/PA n. 003, de 17 de dezembro de 2009. Diário Oficial do Estado. Belém, 18 de dezembro de 2009.

PARÁ. Ministério Público. Icoaraci: MP ajuíza ACP contra o Estado por condições precárias em escola na Ilha de Cotijuba. 12.04.2013. Disponível em: 
http://www.mppa.mp.br/index.php?action=Menu.interna\&id=2182\&class=N. Acesso em: 26.07.2015.

PARÁ. Secretaria de Estado de Educação. Escola Estadual Professora Marta da Conceição em Belém. [2015]. Disponível em: http:/guia-para.escolasecreches.com.br/ensinoregular/ESCOLA-ESTADUAL-PROFESSORA-MARTA-DA-CONCEICAO-belem-belempara-i15042952.htm. Acesso em: 26.08.2015.

PARÁ. Secretaria de Estado de Educação. Consultar Escola. 2016. Disponível em: http://www.seduc.pa.gov.br/portal/escola/consulta_matricula/RelatorioMatriculas.php

Acesso em: 23.02.2016.

PARÁ. Lei n ${ }^{\circ}$ 8.186, de 23 de junho de 2015. Aprova o Plano Estadual de Educação - PEE e dá outras providências. Diário Oficial do Estado. Belém, 24 de junho de 2015. Disponível em: http://fne.mec.gov.br/images/PEE/PAPEE.pdf. Acesso em: 30.04.2015.

PLETSCH, Márcia Denise; GLAT, Rosana. A Escolarização de alunos com deficiência intelectual: uma análise da aplicação do Plano de Desenvolvimento Educacional Individualizado. Revista Linhas Críticas: Revista Semestral da Faculdade de Educação da Universidade de Brasilia - UNB, v. 18, n 35, p.200-211, jan./abr. 2012.

PIOVESAN, Flávia. Convenção da ONU sobre os direitos das pessoas com deficiência: Inovações, alcance e impacto. In FERRAZ, Carolina Valença; LEITE, George Salomão; LEITE, Glauber Salomão; LEITE, Glauco Salomão (coord.). Manual dos direitos da pessoa com deficiência. São Paulo: Saraiva, 2012, p.33-51.

RAWLS, John. Uma teoria de Justiça. Tradução de Jussara Simões. 3. Ed. São Paulo: Martins Fontes, 2008.

RIBEIRO, Lauro Luiz Gomes. Direito Educacional: Educação Básica e Federalismo. São Paulo: Quartier Latin, 2009

RIBEIRO, Lauro Luiz Gomes. Manual dos direitos da pessoa com deficiência. São Paulo: Verbatim, 2010.

RICHARDSON, Roberto Jarry. Pesquisa Social: métodos e técnicas. São Paulo: Atlas, 1999.

ROCHA, Julie. SEDUC já licitou mais de 25 obras nas escolas no interior e capital. [2015]. Disponível em: http://pactopelaeducacao.pa.gov.br/seduc-ja-licitou-mais-de-25-obras-nasescolas-no-interior-e-capital. Acesso em: 26.08.2015.

SANTOS, Batista Moraes dos, Prof. da EEF Marta da Conceição. Informações Verbais. Belém, 2015. Entrevista concedida ao autor desta pesquisa.

SANTOS, Boaventura de Sousa. A gramática do tempo: para uma nova cultura política. 3. ed. São Paulo: Cortez, 2010.

SANTOS, Maria Alba Morais dos, professora da EEEFM Marta Conceição, falando sobre o aluno Joel da Silva Coutinho, aluno da mesma escola que apresenta DI. Informações Verbais. Belém, 2016. Entrevista concedida ao autor desta pesquisa. 
SANTOS, Pedro Henrique França dos. Diretor da EEEFM Marta da Conceição. Informações Verbais. Belém, 2015. Entrevista concedida ao autor desta pesquisa.

SEN, Amartya. Desigualdade reexaminada. Rio de Janeiro: Record, 2001.

SILVA, Isabelle Fiorelli. O Sistema Nacional de Avaliação: características, dispositivos legais e resultados. Est. Aval. Educ., São Paulo, v. 21, n. 47, p. 427-448, set./dez. 2010.

SILVA, Silvânia Gomes, mãe de Geison Silva do Nascimento, aluno da EEEF Marta Conceição. Informações Verbais. Belém, 2015. Entrevista concedida ao autor desta pesquisa.

STAINBACK, Susan; STAINBACK, William. Inclusão: um guia para educadores. Porto Alegre: Artmed, 1999.

TEIXEIRA, Anísio. Educação e o mundo moderno. $2^{\mathrm{a}}$ ed. São Paulo: Cia. Editora Nacional, 1977.

TUNES, Elizabeth; BARTHOLO, Roberto. Nos limites da ação: preconceito, inclusão e deficiência. São Paulo: Edufscar, 2007.

TUNES, E.; PIANTINO, L. D. Cadê a síndrome de Down que estava aqui? O gato comeu... O programa da Lurdinha. Campinas: Autores Associados, 2001.

VELOSO, F.; PESSÔA. S.; HENRIQUES, R.; GIAMBIAGI, F. (Orgs.). Educação Básica no Brasil: Construindo o país do futuro. Rio de Janeiro: Elsevier, 2009.

VIEIRA, Scheilla de Castro Abbud. Professora de Unidade Educacional Especializada a alunos com DI em Belém-Pará, e em Sala de Recursos Multifuncional. Informações Verbais. Belém, 2015. Entrevista concedida ao autor desta pesquisa.

VIGOTSKI, L. S. Obras Escogidas - V, Fundamentos de defectologia. Madrid: Machado Libros, 2012.

WERNER JÚNIOR, Jairo. Universidade Estadual do Rio de Janeiro A medicalização da vida do deficiente como barreira para a inclusão social. In: SEMINÁRIO DA PÓS-GRADUAÇÃO E PESQUISA DE ENGENHARIA (COPPE), 2015, Rio de Janeiro. Anais eletrônicos... Rio de Janeiro: COPPE, 2015. 


\section{ANEXOS \\ ENTREVISTAS REALIZADAS E REFERIDAS NA DISSERTAÇÃO}

\section{ENTREVISTA}

Data: 25 de agosto de 2015

Local: Escola Estadual Marta da Conceição - Cotijuba - Distrito de Icoaraci - Belém / PA

Entrevistado: Diretor Pedro Henrique França dos Santos

\begin{tabular}{l|l}
\hline SÍMBOLOS & LEGENDA \\
\hline $\mathbf{P}$ & Pergunta ou fala do entre vistador \\
\hline $\mathrm{R}$ & Resposta ou fala do entrevistado \\
\hline Itálico & Compreensão duvidosa \\
\hline (0min 0seg) & Trecho não compreensível \\
\hline$\ldots$ & Pausa na fala \\
\hline
\end{tabular}

P: Pode dizer teu nome e há quanto tempo tu trabalhas... E... Nessa área da Educação e, basicamente, quanto tempo está aqui na escola...

R: Certo... Bem... Meu nome é Pedro Henrique França dos Santos né? Estou na... Na área da Educação desde 2008 e na Escola Marta da Conceição há oito meses, como diretor.

P: E... Em relação a essa... Essa... A situação da escola... E quando tu assumiste... É... Quais as informações básicas que tu tens? O quê que... O quê que a escola comporta? Ela atende que séries? Se ela tem anexos e... Quantos professores... Alunos, em média, ela atende...

R: Certo.

P: Dá um panorama geral dessa situação.

R: Tá...

P: Que tu encontraste e que está no momento. 
R: Ok. Bem quando eu assumi a escola em janeiro né? No dia 28 de janeiro de 2015 a escola tinha em torno de 545 alunos né? E estão distribuídos no ensino fundamental menor, primeiro ao quinto ano; fundamental maior, do sexto ao nono ano; e o ensino médio. Nós atendemos essas três modalidades. É... Hoje nós estamos com 761 alunos. Manhã, tarde e noite. E a escola... Ela, na verdade, está passando por um processo de transformação né? Desde que a gente assumiu esta gestão nosso desafio maior aqui dentro da escola é resgatar né? Esses alunos que a escola perdeu por conta de uma série de situações né? Que a escola vem passando aí desde 2009. E aí nós estamos com essa missão hoje na escola de resgatar né? Todo um trabalho que já vinha sendo feito dentro da escola e que ao longo do tempo se perdeu.

\section{P: O que tu... A escola antes de tu assumires ficou quantos meses sem diretor?}

R: Ficou de agosto de 2014 a dezembro. Eu assumi em janeiro. Então esse período ficou sem direção...

\section{P: Aproximadamente quantos meses?}

R: Cinco meses. Ou mais...

P: Nesse aspecto da escola... A escola tem um registro de atendimento... É... Educacional especial. Alunos com deficiência. Principalmente alunos com deficiência intelectual. É... Havia um atendimento anterior na escola e que agora está sendo retomado...

R: Isso. Na verdade é... O atendimento educacional especializado ele não existia. Era feito um trabalho de itinerância dentro da escola né? Nós tínhamos um professor apenas lotado né? Dentro da escola. E aí quando nós assumimos nós pedimos né? Com a Secretaria de Educação para que fossem feitas abertura das turmas do AEE né? Que é o Atendimento Educacional Especializado. Que até então a escola não trabalhava dessa forma. E aí nós garantimos um espaço aqui dentro para que fosse feito esse atendimento. Uma vez que também não tinha o espaço para essas crianças serem atendidas né? E hoje nós estamos aí com uma média de 27 alunos com... É... Necessidade Educacional Especial. 
P: É... Desse universo de 27 alunos... Quantos estão na... De primeira à terceira série... Tens mais ou menos uma informação?

R: É uma média de... Na verdade a maior demanda é do Ensino Fundamental Menor. Que dá uma média de 17 alunos. Em torno de 17 anos...

\section{P: Da primeira à quinta série?}

R: É... Do primeiro ao quinto ano, que é o Fundamental Menor. O restante está distribuído entre o sexto e o nono ano, e médio.

P: E a e a maioria desses 17 alunos... Qual é o tipo de deficiência que eles têm?

R: Deficiência intelectual.

P: É?

R: É... A grande maioria. Deficiência intelectual.

P: E esse atendimento hoje então é feito... É... Aqui tinha o registro de uma sala multifuncional. Pelo registro lá do MEC né?

R: Isso. Na verdade... Essa sala ela nunca... Até então eu desconheço né? A existência dessa sala aqui na escola. $\mathrm{O}$ atendimento ele era feito dentro do laboratório de informática.

P: Sim...

R: Quando nós chegamos aqui nós conseguimos organizar um espaço né? $\mathrm{Na}$ verdade não uma sala...

\section{P: Sim...}

R: Que deveria atender esses alunos... Mas um espaço para que esse aluno pudesse garantir esse atendimento que não era feito. 
P: Sim... E... Existe alguma... É... Previsão nessa... Nessa reforma. De um espaço específico para o atendimento desses alunos?

R: Sim. Na verdade quando nós recebemos a reforma já contempla a sala de recurso multifuncional né? Não só a sala, mas como a escola toda ela vai atender ao projeto da escola acessível...

\section{P: Sim...}

R: Né? Então eu acredito que a partir daí a gente consiga né? É... Garantir esse atendimento de uma forma assim bem... Bem... Mais né? Apropriada para esses alunos.

P: O... No caso do professor Batista que veio para o apoio. É... Ele veio também trazido através dessa... Dessa nova concepção? Quando tu chegastes...

R: É... Na verdade quando eu cheguei o professor já estava.

\section{P: Sim...}

R: Né? Na escola... Ele realizava um trabalho é... Ele mesmo né? Sozinho. E aí quando eu cheguei aqui nós reunimos com a equipe. Conseguimos trazer mais um professor. Hoje nós temos dois professores que trabalham nesse atendimento. E... Na verdade eles atendem hoje, não só a escola sede, mas também os anexos. Que não eram atendidos anteriormente.

\section{P: São dois anexos?}

R: Dois anexos.

\section{P: Quais são os anexos?}

R: É... Anexo Pedra Branca, que fica na área do Poção, próximo à Praia do Vai Quem Quer; e o anexo Urubuoca, que é uma outra ilha. Um pouco mais distante da escola sede. 


\section{P: E esses anexos também têm alunos com...}

R: Temos. Temos alunos lá...

P: Com necessidades educacionais especiais?

R: Isso. Temos...

P: A escola tem algum trabalho em relação a ter mais professores para receber esses alunos?

R: É... Hoje já está com esse olhar né? Que o professor da turma regular ele faça um trabalho em parceria com o professor da sala de recursos né? Em sintonia na verdade. É... Antes nós não tínhamos essa relação. Hoje a gente já pensa que esse trabalho ele precisa acontecer né? De forma com que... Tanto o professor da sala de recursos, quanto o professor da sala regular, eles consigam né? Dialogar e estabelecer um trabalho de parceria. Para que esse aluno possa ter o resultado que a gente espera né? Que tenha...

P: Porque é um processo... É... Que trabalha com diferenças né?

R: Isso...

P: É... Muitas vezes requer que você flexibilize currículos, métodos...

R: Isso...

P: Isso é... Sentes uma dificuldade em relação a esse aspecto?

R: Sinto

P: Tendo em vista que você tem um formato, vamos dizer: já pronto para a escola... O meu Deus!

R: É... Até o próprio discurso de inclusão né? 
P: É...

R: Quando você fala em incluir...

P: Essa é uma dificuldade.

R: Aí eu deixo o... O professor da turma regular fora do processo de inclusão aí cai por terra todo o meu discurso né? Então a gente tenta, da melhor forma possível, incluir todos eles né? Que fazem parte desse processo.

P: É porque um dos grandes desafios... Que quando a gente fala em inclusão é porque existe exclusão.

R: Isso.

P: Não é?

(Risos)

P: Isso é muito difícil porque não depende só da escola... Depende da família... Eu conversando com os professores anteriormente eles me disseram que tem muitas famílias que... Quer dizer, as crianças ainda sequer ainda frequentaram a escola não é? O quê que tu pensas? Tu tens conhecimento também disso?

R: É... Na verdade a gente observa...

\section{P: A participação da família...}

R: Que há uma resistência também muito grande da família quando é o professor da sala de recursos e o professor da turma regular observam que tem algo de diferente né? Então quando essa família ela é chamada na escola para que seja feita uma avaliação né? Para que a gente possa acompanhar e tentar chegar a um... A um.. Digamos: a um diagnóstico com uma... Com toda uma equipe né? Profissional para isso... Ainda assim a gente encontra uma resistência da família. Porque tem a questão desse acolhimento dessa criança que passa né? A 
ser visto de forma diferente pelo aquele colega que está dentro da sala. Então a gente precisa na verdade fortalecer esse discurso dentro da escola não só para o aluno da Educação Especial. Como um todo. Porque quando se fala né? Da questão inclusão... Eu não falo só do aluno é... Que tem uma necessidade educacional especial. Eu falo do todo.

\section{P: Sim...}

R: Né? Então a gente precisa desmistificar também isso...

P: Quer dizer: você tem que trabalhar também os demais alunos que muitas vezes é... É... É... Vamos dizer: rejeitam aquele aluno diferente também...

R: Sim. Sim. Não só... Como eu falei né? Não só a criança que tem alguma deficiência, mas também a criança que digamos... É... É... Tem um pouco mais de dificuldade financeira né? A questão da cor né? Então tudo isso a gente trabalha dentro da escola para que a gente quebre né? Com esse... Esse pré-conceito. Esses rótulos que se criam.. E que impede muitas das vezes que o professor realize determinado trabalho dentro da escola.

P: É... A própria escola passa por um momento difícil não é? Que eu te disse... Então... É... A própria escola não deixa de ser também um pouco discriminada. Ainda em certos aspectos né? Eu acho que é um dos trabalhos importantes teus é... É resgatar essa... Essa... Essa autoestima da escola né?

R: Sim. Acredito que é um grande desafio para a Escola Marta...

\section{P: É... Teu e dos professores também...}

R: Isso. Para toda a equipe que está aqui hoje é um grande desafio por conta da situação da escola né? É uma escola que ao longo do tempo perdeu a... A... A... A sua identidade né? E a própria comunidade ela... É... Meio que desacreditou do trabalho que vinha sendo feito né? Então nós estamos é... Com essa preocupação hoje de fazer um resgate né? E é por isso que a gente tem um lema esse ano dentro da escola, nesses 46 anos de Escola Marta, de um próprio resgate dessa... Dessa identidade deles né? Criar uma identidade e resgatar também essa cidadania deles que está um pouco perdida, que está um pouco confusa né? Então eu acredito 
que esse ano é desafiador nesse sentido. A comunidade ela volta a acreditar no trabalho né? Se fortalece, mas sabendo que nós temos ainda muitos desafios né? A serem enfrentados aí...

P: Porque numa comunidade como essa aqui de Cotijuba e das ilhas, quer dizer, a educação é aquela porta que se abre para algumas oportunidades...

R: Sim.

P: Entendeu? E muita das vezes você só tem na escola pública, como é o caso aqui da Marta da Conceição, essa possibilidade... O quê que você... É assim... Nesse olhar... Chegando aqui... Você que veio de fora... Também tem uma visão de fora da comunidade em relação a esse aspecto da educação...

R: É... Na verdade a... Quando você está fora né? Você tem uma ideia da... Da... Da coisa. E quando você passa a vivenciar isso né? E passa a compartilhar essa... Essa luta. Com essa comunidade... Você observa que... Que de fato é... Eles depositam uma... Uma esperança muito grande. Porque é... Como você mesmo falou a pouco né? É uma porta que se abre. Então a partir do momento em que essa porta se fecha e eu não tenho mais... Não vejo mais possibilidades de a partir daqui crescer né? Eu vou acreditar em quê? Então eu acredito que esse ano, como eu digo, é desafiador por conta de... De... Dessa comunidade se reconhecer, acreditar que é possível através da educação né? Criar essas pontes novamente para que se possa buscar coisas melhores. Que é o que a grande maioria dos nossos jovens, crianças aqui, lutam né? Por um espaço no mercado de trabalho, por qualificação né? Por uma vida melhor. $\mathrm{Eu}$ acredito que é isso.

P: É... O perfil do aluno da... Do Marta... É... O quê que... Nesse caso dos alunos com necessidades educacionais especiais... É de alunos carentes. De famílias sem recursos financeiros maiores...

R: Isso. A própria realidade da ilha no geral é uma comunidade muito carente. Em todos os sentidos. Né? Então quando se fala desse resgate é justamente de... Da escola é... Exercer também a função dela. A função social que ela tem né? E ao mesmo tempo dar essa garantia para essa familia né? Então muitas das vezes o professor ele acaba sendo que um segundo pai para esse aluno. Porque o próprio pai, que muita das vezes não acredita, quando chega na 
escola esse professor ele motiva, ele dá essa gotinha de esperança que esse aluno muitas das vezes perde lá dentro de casa. Por conta dessas dificuldades também né? A questão do acesso à escola que muitas das vezes é... É difícil para esse pai trazer esse filho até a escola né? E muitas das vezes o professor ele intervém nisso né? Então aqui é todo um trabalho é... Em conjunto né? Escola, família... Para que a gente não... Não perca né?

P: É só para... É... É...

R: Parou...

P: É só para encerrar... A gente pode conversar mais depois. Mas acho que um dos pontos importantes, apesar dos do esforço da... Da direção, dos professores... Mas há uma necessidade também de que você tenha recursos necessários para poder você realizar esse trabalho.

R: Sim.

P: Né? E eu vejo que a escola também se ressente dessa... De uma... De um aporte maior de recursos para isso.

R: Isso. É... Na verdade...

P: E o quê que tu podes falar nesse histórico da escola em relação a isso?

R: A... Eu costumo dialogar com a comunidade no sentido de: nós precisamos participar mais é... Da escola, da vida escolar... Né? Dos filhos deles. Por quê? É... A escola ela... Ela... Deixou... Infelizmente né? Se perder muita coisa. E a comunidade ela não conseguiu acompanhar também tudo isso. Então... A medida em que eu não acompanho um trabalho e a escola deixa de receber, digamos, alguns recursos que seriam essenciais para que a gente possa realizar algumas atividades dentro da escola. E aí... Desde 2009 a gente está impossibilitado de ir receber... É... PDE né? Mais Educação... Então... Como a comunidade ela não acompanhou tudo isso e não teve uma cobrança da própria comunidade no sentido de fiscalizar né? Ver se o recurso estava chegando na escola. Como não teve esse acompanhamento a escola é... Passou a não receber mais esses recursos. Então a própria 
comunidade desconhecia também essa função... Esse papel de fiscalizar e acompanhar é... Tudo o que a escola recebe e que precisa né? Prestar conta com essa comunidade para que se possa... Possa também ser feito um trabalho de qualidade. Então à medida em que a escola hoje recebe uma reforma e não tem recurso para poder manter aquilo que vai ser feito é um pouco complicado. Então hoje nosso papel aqui dentro é trabalhar né? Com essa comunidade para que ela possa é... Ter consciência do papel que ela tem dentro da escola, para que ela possa fiscalizar, para que ela possa cobrar... E para que a gente possa manter tudo aquilo que vem sendo feito por parte da Secretaria de Educação aqui dentro da comunidade da Ilha de Cotijuba.

\section{P: É... Especificamente... Você poderia assim... É... Pontuar alguns... Algumas questões de recursos que a escola precisa nesse momento...}

R: É... De emergencial seria o fundo rotativo. Mas...

\section{P: O que é o fundo rotativo?}

R: É para pequenos reparos né? Para fazer pequenos reparos. É... Até a compra de material também. De expediente também para escola. Esse fundo ele supre né? Essas necessidades básicas nossas. É... No entanto a gente está impedido de receber por conta dessas prestações de contas que vem desde 2009... E aí Ministério Público está acompanhando tudo isso... É... Mas não deu ainda um parecer para nós né? Então a escola está impedida desde 2009 de receber tantos recursos do governo estadual quanto do governo federal. A escola só passa a receber novamente esses recursos né? A própria Secretaria de Educação ela informa isso, via documento, para a gente quando a escola estiver quite com todas essas prestações de contas. Nós estamos tentando formalizar um novo conselho para que seja liberado, pelo menos o fundo rotativo, que é esse fundo emergencial... Para a gente conseguir fazer alguma coisa aqui dentro da escola.

\section{P: Quer dizer, atualmente a escola não tem um conselho de... De educação?}

R: É. Na verdade nós ainda temos um conselho de 2011 que ainda está ativo lá para a Secretaria de Educação né? Bem como toda a questão bancária né? Conta em banco, cartão... Para a Secretaria de Educação que está em vigor ainda é o último conselho de 2011. 


\section{P: E isso precisa ser atualizado?}

R: Precisa ser atualizado. É o que nós estamos fazendo né? Mobilizando aí a comunidade... Sensibilizá-los né? Para que eles tomem consciência da... Também da função do Conselho... Foi por isso também que a escola se perdeu. Porque não se sabia qual era a função do Conselho Escolar né? Que não é só... É fiscalizar também a questão dos recursos que vêm. Mas tem todo um trabalho em relação ao conselho escolar né? Que envolve também um pouco do pedagógico. Também dentro da escola. E a comunidade desconhecia... Essas...

Essas... É... Esses setores, esses órgãos... Então ficou difícil para acompanhar. Então hoje a gente tá fazendo esse trabalho para que quando a comunidade tiver consciência de tudo isso a gente consiga desenvolver um trabalho melhor aqui dentro da ilha.

\section{P: Inclusive em relação a esses recursos pedagógicos para os alunos especiais?}

R: Sim. Sim. Que já deveria né? É... Ter uma sala de recursos multifuncionais e os equipamentos necessários também. É... Se não me falha a memória... É... Chegou uns equipamentos para a escola e veio notebook. A única coisa que chegou até a escola foi o notebook com uma impressora para sala de recursos multifuncionais. Esse equipamento está sendo usado pelo professor né? Mas deveria ter vindo outros equipamentos para essa sala de recursos e eu não sei por que não chegou até aqui. Na escola...

P: É que pelo... Pelo cadastro que a gente vê lá do MEC... É... A escola, pelo menos formalmente, teria... É... Alguns equipamentos... Aqui chamados: kit um, kit básico... Para... Para o atendimento ao aluno com necessidades educacionais especiais. Isso aí não chegou na escola? A não ser esse equipamento... É... Digital...

R: Isso. É... Eu não tenho conhecimento de todo esse equipamento né? Que chegou na escola... Até porque muita coisa se perdeu...

\section{P: Entendi...}

R: Né? Muito documento da escola... Quando a... Nós assumimos a gestão da escola... Muito documento já não existia mais... Né? Então muita coisa se perdeu. Muita coisa se levou da 
escola né? Com a ação do Ministério Público em 2014... Pós-ação do Ministério Público né? Muitos documentos se perderam. Então eu não tive acesso. Eu já recorri à SEDUC, já recorri à Unidade 12 né? Que é a unidade que está responsável pela gerência da Escola Marta da Conceição. E eles também não têm nenhum documento que possa dar esse respaldo para a gente...

\section{P: Então a escola, necessariamente, passa por um processo de reorganização?}

R: Sim. Sim. Reorganização total. Não só da questão de documentação, mas também reorganização das pessoas que fazem parte dessa escola. Nós também estamos com uma nova equipe dentro da escola... E...

\section{P: E qual que seria a... Assim a... As tuas esperanças... Perspectivas... Diante desse novo processo... Do qual tu participas juntamente com essa nova equipe...}

$\mathrm{R}$ : Eu quero acreditar que com essa nova equipe que nós temos hoje aqui dentro da escola e que se mostra disposta né? A fazer um trabalho diferenciado na educação das ilhas... Eu quero acreditar que a gente é... Já conseguiu alguns avanços e que nós teremos ainda mais. Porque é uma equipe que, além de realizar o trabalho todos os dias aqui na escola, é uma equipe que corre né? Atrás... Também dessas... Eu vou usar esse termo né? Dessas falhas... Que nós tivemos aí na... Há alguns anos atrás. Então nós não esperamos por Secretaria de Educação, nós não esperamos por Unidade 12. Nós estamos correndo atrás de tudo aquilo que ainda... É... É... Não... Não deram resposta para a gente. Esses... Esses espaços, essas lacunas que ficaram ao longo dos anos... Nós estamos correndo atrás. E... Graças a Deus é... Nós já estamos tendo algumas respostas da Secretaria de Educação. Tanto é que a reforma saiu né? Já com alguns anos aí de licitação... E nunca saía a reforma da escola. E nós já conseguimos garantir algumas coisas aqui para as escolas e para os anexos da Escola Marta da Conceição.

P: Ok então professor. Tá? Obrigado então por essa sua primeira entrevista. A gente retoma mais... Depois que a gente fizer mais algum outro levantamento... Algumas perguntas a mais... 
$\mathrm{R}$ : Eu agradeço também né? E já me coloco à disposição, assim como toda a equipe da Escola Marta... Nós estamos à disposição do senhor para... Para responder todas as perguntas e contribuir né? Com seu trabalho...

\section{P: Tá... Muito obrigado então...}

R: Me dá este pão...

P: Não... Mas é...

R2: Agente é barulhento

P: Não... Na verdade...

\section{TEMPO TOTAL $=24 \mathrm{~min} 45 \mathrm{seg}$}

\section{ENTREVISTA}

Data: 04 de fevereiro de 2016

Local: Escola Estadual Marta da Conceição - Cotijuba - Distrito de Icoaraci - Belém / PA

Entrevistado: Diretor Pedro Henrique França dos Santos

\begin{tabular}{l|l}
\hline SÍMBOLOS & LEGENDA \\
\hline $\mathbf{P}$ & Pergunta ou fala do entrevistador \\
\hline $\mathrm{R}$ & Resposta ou fala do entrevistado \\
\hline Itálico & Compreensão duvidosa \\
\hline (0min 0seg) & Trecho não compreensível \\
\hline$\ldots$ & Pausa na fala \\
\hline
\end{tabular}


P: É... Filmando... Mas é... Aqui falando com o diretor Pedro no dia 4 de fevereiro de 2016. É... Nesse período aqui a escola já está concluída... A... Pelo menos $90 \%$ da... Da... Da parte de estrutura da sala. E... Estamos na segunda semana do... Do retorno do ano letivo ainda de 2015. E aí eu queria... Começando... Perguntando exatamente para o diretor. Para o Pedro. É... Como é que foi o início? Esse retorno da escola... E... Ao final falando sobre a questão da... Diretamente do atendimento do aluno com necessidade especial, com deficiência intelectual...

R: Esse retorno ele foi bem desafiador né? Porque nós não imaginávamos que o nosso aluno ele fosse retornar. Uma vez que nós estávamos né? Com a escola praticamente parada né? Então tendo esse retorno do nosso aluno já foi bem positivo porque ele voltou para escola. Ele acreditou né? Que a escola poderia mudar como está mudando. Infelizmente ainda não é aquilo que a gente realmente quer para o nosso aluno né? Ainda falta muita coisa...

\section{P: Por exemplo...}

R: Mas... É... Dentro daquilo que a gente esperava né? Que é uma sala de aula melhor para esse aluno né? Um espaço pedagógico dentro da escola. A gente tá conseguindo né? Aos poucos, de forma bem gradativa mesmo, dar isso que o aluno precisa. Não só para que ele fique com as... As aulas de sala de aula, mas que ele consiga explorar. Além da sala de aula né? E para o nosso aluno com necessidade educacional especial nós ainda temos ainda muitos desafios. Porque não é só uma sala de recursos né? Isso é uma das coisas que a gente sempre fala que dentro da escola... É a formação desse professor né? É a participação dessa família... É esse aluno vir para a escola, para o atendimento educacional especializado... Enfim... É um conjunto de ações que a gente vai precisar ainda né? Dentro da escola consegui fazer com que todos desses participantes tenham consciência de que não é só apenas uma sala de recursos equipada, mas que a gente precisa, na verdade, envolver todos nesse processo.

P: É... Nós temos... Além da... Da escola Marta da Conceição, nós temos os dois anexos: de Urubuoca e da Pedra Branca. Que lá, diferente daqui, nós temos um ensino multisseriado né? $\mathrm{E}$ a professora fica na sala de aula com vários alunos, de vários anos... Primeiro, segundo e terceiro ano, por exemplo. É... E eu vejo que é onde se tem menos apoio né? Quais são as perspectivas e como é que funcionam atualmente esses anexos? 
R: Na... No anexo da Pedra Branca é um pouco mais difícil para a gente tentar... É... Contornar essa realidade de multisseriado porque nós temos apenas uma sala de aula né? E um professor... Então...

\section{P: Atende quantos alunos?}

R: Nós atendemos hoje 14 alunos né? Então... É todo um grau de dificuldade ali dentro da realidade do anexo Pedra Branca que dificulta com que a gente consiga atender da melhor forma possível essa criança. Para que a gente consiga até sair dessa ideia de multisseriado. Porque é muito difícil, até para o professor, lidar com uma diversidade muito grande dentro da sala de aula. Que a gente já sabe que é difícil numa turma regular. Onde eu tenho apenas uma série. Você trabalhar com várias cabeças né? E... E... E essa diversidade que a gente encontra dentro da escola... Imagina para uma turma de multisseriado né? É bem mais desafiador. Mas infelizmente a gente ainda não conseguiu, dentro do anexo da Pedra Branca, por conta da própria estrutura da escola não dá condições para que a gente consiga... É... Desmembrar isso né? Então com 14 alunos é humanamente impossível você dividi-los: dois, dois, dois... Para um professor né? Então acaba que a gente... Ficando ainda nesse sistema multisseriado. O anexo Urubuoca... Nós estamos aí com fase de... Licitação para a construção de um novo anexo. Que deve começar a partir de março. Então lá... Para 2016 a gente já tem uma ideia... Isso já foi discutido com a professora Kátia. De que a gente consiga é implementar um ensino fundamental. É... Do primeiro ao quinto ano regular e tirar o ensino multisseriado. Lá nós já temos duas professoras né?

\section{P: Além da Kátia?}

R: Além da Kátia.

\section{P: Quais são as professoras?}

R: Professora Maria Alba e professora Ivone.

\section{P: Tá...}

R: Que vão para o anexo esse ano né? Para a gente tirar o ensino multisseriado... 


\section{P: A Kátia continua?}

R: A Kátia continua. E essas professoras elas estão pegando a sua carga horária máxima que é 200 horas ou 40 horas né? Então elas vão trabalhar dois turnos. E aí a gente consegue, pelo menos, ter uma turma de cada série para a gente poder sair desse sistema de multisseriado...

\section{P: Então vai ter primeira, segunda e terceira série?}

R: Isso. Até o quinto ano na verdade né? Primeiro, segundo, terceiro, quarto e o quinto ano no anexo Urubuoca.

P: E... A questão do transporte? Aí do anexo Urubuoca... Ele atende a alunos que estão em quatro Ilhas não é isso?

R: É. Na verdade são os alunos que moram próximo do anexo. As Ilhas próximas ao anexo Urubuoca...

\section{P: E quais são as ilhas?}

R: Né? Nós tivemos esse cuidado na... Na lotação... De colocar o aluno próximo de casa. Então antes... O aluno que morava no Urubuoca ele estudava na escola sede. E aí se eu tenho a... O anexo que pode atender esse aluno... Nós tivemos esse cuidado. Então o transporte ele funciona: na ilha de Urubuoca, a frente do Urubuoca, a costa do Urubuoca... E... Nós temos Ilha Longa, Ilha Nova e ainda tem alunos que vêm dos furos: Jamaci, Arapiranga né? Mas tudo bem próximo do anexo.

\section{P: Hoje o Urubuoca ele atende a quantos alunos?}

R: Ele está em torno de 65 alunos.

\section{P: É um número significativo...}


R: Isso. E esse ano a gente pretende ampliar né? Uma vez que a gente está mexendo, saindo do sistema multisseriado... E abrindo para o ensino fundamental, do primeiro ao quinto ano, a gente é... Tem a ideia de deixar ele como referência do primeiro ao quinto ano.

P: E esse... Essa questão do atendimento ao ribeirinho... O transporte... É... Fluvial... Tem funcionado? Agora. Para o transporte desse aluno...

R: Sim. Sim. É... A gente conseguiu avançar muito. Precisa avançar ainda mais. Mas eu penso

que com essa... É... Nova estrutura né? Nova empresa também que entrou... Nós conseguimos avançar muito no transporte escolar né? Nós tínhamos, como exemplo, embarcações que não tinham o necessário para o aluno né? Para garantir a segurança desse aluno dentro das embarcações. Hoje nós temos. Né? A gente sabe que ainda é... É necessário que a gente consiga aumentar a demanda por que nosso número de alunos cresce a cada ano. Mas é uma coisa que a gente também sempre dialoga com a SEDUC para que nos de condições para atender essa criança.

P: E em relação à merenda escolar? Esses alunos se deslocam... Como tem sido a regularidade do fornecimento dessa merenda?

R: Nós tínhamos um grande problema com a merenda porque ela nunca conseguia chegar até a escola. E os anexos eles não são diferentes disso. Uma vez que eles ficam mais isolados da escola sede né? Hoje a gente consegue dialogar com a SEDUC e essa merenda consegue chegar até escola. Às vezes...

\section{P: Isso foi regularizado de quanto tempo para cá?}

R: Tem um ano. Um ano. Que foi que a gente conseguiu regularizar a merenda escolar. Não só a merenda, como o livro didático e outras coisas que a escola precisa receber que não chegavam até a escola. E a gente conseguiu fazer com que a SEDUC entendesse que a responsabilidade é dela. E ela precisa fazer com que isso chegue até o aluno. Né?

P: A questão, por exemplo: nós temos é... Do primeiro ao terceiro ano, fundamental... É... Pelo menos é... Na legislação não tem nenhuma garantia, por exemplo, de professor auxiliar. Principalmente para alunos com DI. Né? Isso nós não temos ainda né? Essa é 
uma dificuldade? Porque nem sempre o Batista pode estar presente em todos os momentos, em todos os lugares ao mesmo tempo...

R: É... A Secretaria de Educação está trabalhando para discutir esse ano a questão do reordenamento. Onde justamente ela vê as escolas que concentram um número... Né? De profissionais que não condiz com a realidade da escola. Para estar fazendo esses ajustes. Então nosso caso, do Marta da Conceição, onde eu tenho um professor para atender a escola sede e mais dois anexos... Eu necessito de mais. Pelo menos um profissional para tá dando esse suporte para o nosso professor do AEE. E é isso que a equipe da educação especial esteve a... Há poucos dias na escola para a gente tentar... É... Resolver esse problema né? Uma vez que... É... Isso já vem se arrastando por muitos anos né? E a gente já sabe da dificuldade das escolas que estão próximas à Secretaria de Educação... A gente faz ideia para uma escola de... O quão é difícil esse profissional chegar até aqui. Mas a gente percebeu que há uma preocupação. Já há uma discussão nesse sentido para que esse profissional ele consiga chegar até a escola.

\section{P: Chegastes a formalizar isso?}

R: Sim. Sim...

\section{P: Isso está?}

R: Está. Todo documentado...

\section{P: Chegastes a fazer esse pedido?}

R: Sim, $\operatorname{sim} .$.

P: A questão também do... Da formação dos professores... É... Nessas entrevistas foi o que eu mais... É... O professor reclamou... É a falta de formação para atender esses alunos com necessidades educacionais especiais.

R: Na verdade nós temos um histórico de abandono. E não só o aluno da turma regular, e os professores dessas turmas regulares ficaram sozinhos como o professor também da Educação 
Especial. E esse aluno que necessita de um atendimento especializado... E hoje na... Na... Dentro do que a gente se... Discute dentro da escola... Que se propõem... A gente tem todo esse olhar. De que não sou professor da turma regular precisa de um acompanhamento constante, como o professor também que faz esse atendimento educacional especializado. Então nós já solicitamos à diretora da unidade de Educação Especial que ela faça né? Esse acompanhamento. Que envolva os nossos professores nas formações e que a gente consiga ter um resultado melhor para esse aluno. Porque o nosso foco dentro da escola é o nosso aluno.

\section{P: Porque até então isso não estava ocorrendo né?}

R: Não. Na verdade o nosso professor ele não tinha nem um espaço para atender esse aluno né? Quando nós chegamos aqui nós identificamos... A primeira coisa que nós identificamos: foi esse professor tendo que atender dentro do laboratório de informática, tendo que atender na secretaria, às vezes, na sala da direção... E nós tivemos esse cuidado de... É... Colocar esse profissional, e essa criança, no espaço onde a gente conseguisse é garantir o mínimo... Porque a gente sabe que ainda não... Nós não tínhamos. Mas foi o que a gente conseguiu fazer. E hoje a gente lutou e aí está só aguardando mesmo a finalização da obra para que a gente consiga ter esse espaço apenas para a educação especial.

\section{P: E as verbas para manutenção aqui? Se regularizou? Como é que está essa questão aí?}

R: Nós conseguimos a liberação do fundo rotativo né? Da escola. É um recurso estadual. E aí a... O grande "X", hoje da questão, é os recursos federais. Nós já fizemos a solicitação lá na Secretaria de Educação porque nós tentamos implementar, por duas vezes, o conselho escolar e nós não vimos interesse. Uma vez que a comunidade... A própria comunidade e os pais... Os professores já estavam assim... Bastante desmotivados em relação ao conselho porque nós tínhamos um conselho que não funcionava, não prestava contas... Então para eles não seria interessante mais um conselho que tivesse na escola para não gerenciar... Não só o recurso, mas também como a parte pedagógica da escola. Então nós estamos encontrando ainda essa dificuldade. Fazer com que ele perceba que o conselho escolar é uma ferramenta essencial para o trabalho de escola e que ele não está só para gerenciar recursos. Então nós estamos aguardando uma equipe da SEDUC que vem fazer esse trabalho de sensibilização da comunidade, dos profissionais da escola, dos alunos... Para que eles tomem consciência da 
importância do conselho escolar, para que a gente consiga a liberação desses recursos federais que são importantes para o desenvolvimento do trabalho da escola.

P: Mas... Uma coisa também até que eu discuti ontem com a Irene... É a falta de uma... Uma diretriz operacional né? Da política. Que nós não temos no estado né? E eu vejo que isso... Quer dizer, você não tem um padrão de funcionamento para atender esses alunos. Isso realmente não né?

R: Falta. Realmente falta. E é uma das coisas que a gente sempre coloca nos encontros... Até nas próprias formações... Mas a gente ainda encontra essa dificuldade. Infelizmente... É uma coisa que... Eu acredito que a gente ainda vai precisar de um tempo maior para tentar reajustar ou resolver da melhor forma possível...

\section{P: Você quer concluir? É... Alguma coisa em relação à pesquisa?}

R: É... Eu gostaria de... Até te agradecer né? Por que... É... Com esse trabalho a escola ela conseguiu avançar muito. Porque eu costumo dizer que nós não somos... Nós não conseguimos nada sozinho né? E... A... A contribuição... A sua contribuição ela foi assim... Essencial para que a gente pudesse dar encaminhamento em coisas que a gente também já estava engatado há muito tempo né? Então eu sempre digo que aqui na escola a gente sempre busca dar espaço e oportunidade para pessoas e projetos que possam... É... Dar continuidade e melhoria para o trabalho da escola. Tudo que acrescenta, que agrega, a gente abre espaço... E com seu trabalho não foi diferente né? Eu acredito que a gente conseguiu avançar muito né? No diálogo. Não só com a Secretaria de Educação, mas como os profissionais da nossa escola. E eu penso que o caminho é esse. A gente precisa continuar nesse caminho porque a gente vai trazer com certeza melhores resultados para escola.

P: Tá... Eu agradeço então diretor a disponibilidade de... De abrir aqui, inclusive os próprios arquivos... Para... $E$ as informações e os professores que ficaram disponíveis para prestar informações aqui para a minha pesquisa. Então eu queria agradecer... Eu vou dar o retorno para vocês. Da mesma maneira que eu dei o retorno aí da... Do documentário. E... $\mathrm{E}$ já lhe adiantando que nós queremos fazer críticas...

R: Sim. 
P: Críticas construtivas né? Algumas positivas, outras negativas... Em relação a essa questão da política educacional da pessoa com deficiência. Para que a gente possa no futuro né? Ter melhores momentos... Mais inclusivos para esse segmento...

$\mathrm{R}$ : E é isso que a escola precisa.

P: Obrigado. Então é isso Pedro. Te agradeço então esse apoio...

R: Eu que agradeço.

P: E...

R: Muito...

P: Assim que eu tiver...

TEMPO TOTAL $=16 \mathrm{~min} 29 \mathrm{seg}$ 


\section{ENTREVISTA}

Data: 25 de agosto de 2015

Local: Escola Estadual Marta da Conceição - Cotijuba - Distrito de Icoaraci - Belém / PA

Entrevistado: Professor Batista Moraes dos Santos

\begin{tabular}{l|l}
\hline SÍMBOLOS & LEGENDA \\
\hline $\mathbf{P}$ & Pergunta ou fala do entrevistador \\
\hline $\mathrm{R}$ & Resposta ou fala do entrevistado \\
\hline Itálico & Compreensão duvidosa \\
\hline (0min 0seg) & Trecho não compreensível \\
\hline$\ldots$ & Pausa na fala \\
\hline
\end{tabular}

\section{P: Vamos lá...}

R: Bom... O meu nome é Batista Moraes dos Santos né? Eu trabalho na educação desde 97. Então já são 18 anos né? Mas na área da Educação Especial eu trabalho pouco tempo... Assim direcionadamente né? Desde o concurso. Foi em 201. Mas assim... A gente já trabalhava é... Com alunos da Educação Especial numa outra escola. Mas sem ser professor da classe especial a gente trabalhava num projeto de apoio pedagógico né? Ali na escola Bosque. Mas na área mesmo da Educação Especial eu vou fazer... Tem... Fiz há pouco tempo dois anos...

\section{P: E aqui na Escola Marta da Conceição?}

R: Eu ainda vou fazer um ano. Eu cheguei aqui no dia 4 de setembro de... De 2014.

\section{P: Antes tu trabalhaste aonde?}

$\mathrm{R}$ : Eu trabalhava na Pratinha. A minha chamada no concurso ela foi para uns e um... Aí eu fiquei na escola Sagrada Família na Pratinha. E depois eu fiquei na Nossa Senhora das Graças. Aí de lá que a minha remoção veio pra cá. Aí eu fiquei trabalhando lá um ano e meio.

\section{P: E tu sempre moraste aqui?}


R: Sempre morei aqui. $\mathrm{Na}$ verdade... Assim o pouco tempo que eu passei fora, um ou dois anos, sempre foi para estudar. Mas eu sempre morei aqui mesmo né?

\section{P: Então tu pertences à comunidade daqui de Cotijuba?}

R: É... Na verdade... Eu estudei nessa escola desde o início né? E saí daqui porque ela tinha até o... Na época era oitava série. Aí daqui que... Aí eu morei dois anos em Icoaraci que era para fazer o magistério. Mas aí eu voltei de novo. Então eu sempre vou e venho, não consigo me desprender daqui.

P: E... Em relação ao atendimento de alunos com deficiência intelectual? Esse teu trabalho... É... O quê que tu observa aqui na escola? É... Pode se falar de uma maneira mais abrangente. Tanto a nível da escola, a nível da família... Os recursos pedagógicos que tu dispõe...

R: Dentro da realidade da Marta da Conceição... Eu vou te dizer que é bem difícil né? Em relação, por exemplo, às outras escolas que eu trabalhei. Era bem melhor. Não em termos de estrutura. Até em termos de estrutura eu poderia te dizer que aqui está bem melhor antes da reforma né? Que nas demais escolas... Mas assim... É... Era a questão de espaço. A gente não tinha espaço. O espaço da Educação Especial quando eu cheguei ele estava sendo ocupado é... Por uma turma regular né? Então nós não tínhamos o espaço para o atendimento da Educação Especial.

P: Ou seja, a sala multifuncional não estava funcionando?

R: Não tinha.

P: Estava no papel, mas não estava garantido na prática...

R: É... Na verdade ela existia só que... Eu não sei te dizer o quê que aconteceu ao longo dos anos né? Com aposentadoria da professora Dora e aí... No...

P: A professora... 
R: Tinha professor né? Mas eles desativaram.

P: A professora Dora era a professora que... Que...

R: Do atendimento especial aqui...

\section{P: E ela parou de atender em que período?}

R: Eu acho que foi $2010 / 2011 \ldots$ Não sei precisar bem isso...

P: Então a escola ficou praticamente três anos sem atendimento educacional especial? De 2011 até 2014?

R: É... Foi mais ou menos isso. Aí quando eu tomei conhecimento que ela havia se aposentado... Foi logo que eu passei no concurso. Aí ela... Aí eu fiquei tentando a vaga né? A permuta pra cá. Só que não havia permuta porque não houve... Não houve professor para ser lotado aqui. Ninguém queria vir pra cá. E aí eu fiquei na... Esperando mesmo né? Para ver o que acontecia... E aí quando eu cheguei aqui esse espaço ele já era ocupado né?

\section{P: Antes? Na época da professora Dora funcionava...}

R: Na época da professora funcionava. Tỉnha o espaço, tinha a sala da Educação Especial né? Onde esses alunos eram atendidos. Eu até cheguei a ver a... Várias vezes ela e uma outra professora, a professora Rosana, que também se aposentou, fazendo atendimento desses alunos é... No... No AEE né?

\section{P: No contra turno?}

R: Isso. Porque aqui ainda tinha o itinerante. Também né? Que hoje já está um pouco mais esquecido né? Aí...

P: Ou seja, o professor itinerante... 
R: É... Na verdade pensam assim.. Em se retirar esse profissional né? Das escolas... Ficar apenas um nas USES para... Para atender as escolas que tem uma demanda muito pequena, que não consegue lotar um professor né? Aí esse professor vai à escola e faz atendimento né? Então por isso estão retirando esses profissionais das escolas né? Aí, por exemplo, questão de material... É... Ao longo do tempo, eu não sei te dizer o que aconteceu, mas, por exemplo, a gente foi encontrando os materiais, mas já havia um desgaste desses materiais né? Peças faltavam de uns né?

\section{P: Por exemplo...}

R: É... Por exemplo, jogo da memória... Por exemplo, o teclado colmeia que é para alunos com... Com dificuldades motoras... Por exemplo, estava quebrado e eu não encontrei mais o computador que era da Educação Especial... Apesar de perguntar, não encontrei... A impressora né? É... O kit tecnológico, de uma forma geral, não foi... Não consegui mais encontrá-lo né?

\section{P: Então vai ter que requerer um novo?}

R: Pois é... Eu até fiz isso. Eu entrei lá no site, não sei se vem né? Mas eu fiz a solicitação né? Solicitando um o kit tecnológico para educação especial. Para ver se a gente melhora o trabalho né? Porque na verdade... É assim... A gente trabalha o material que agente confecciona né? O jogo da memória, o quebra-cabeças... Essas coisas que você constrói no dia a dia com eles, mas assim... Um material de apoio mesmo... Oferecido pelo governo do estado, não tem...

\section{P: E... E aqueles materiais que vem do MEC? Porque o MEC tem um kit né?}

R: É...

\section{P: Tem o kit um, o kit dois...}

R: Isso, isso... Pois é... Pelo que eu percebi aqui, foi o kit um que veio, porque o kit 2 ele é mais completo né? Mas aqui veio básico, que é o um. Esse que eu te falei que... Que não... Que tem o material dourado, se não me engano, tem o bloco lógico, tem instrumentos 
musicais, tem os livros de formação do professor, é... Atividades para os alunos no computador...

P: Então tanto os equipamentos, como o material pedagógico... Tu não encontraste aqui para dar um atendimento de maior qualidade ao aluno?

R: Não. Não encontrei...

\section{P: Isso te dificulta 0 ?}

R: Dificulta bastante né? Porque são coisas que, por exemplo, um aluno como Diego... O Diego ele tem dificuldades motoras né? Então você precisa de uma atividade bem mais direcionada para ele né? O DI... Ele é DI. E tem também dificuldades motoras. No caso ele já viria a ser um múltiplo né? Agora pela... Porque antes eram duas, agora já são... Eram três, agora são só duas. E aí esse aparelho... Esse teclado colmeia, por exemplo, facilita o acesso dele ao computador né? Porque como ele não tem... A coordenação dele ele é... É um pouco prejudicada e aí então esse teclado ajuda muito ele né? Então nesse sentido ajudaria muito, muito mesmo né? Mas tem algumas coisas que a gente faz... A gente engrossa o lápis, por exemplo, com.. Com a fita né? Para que eles possam ter... A gente trabalha com a questão do fazer o desenho. Tipo a gente põe a moldura e o... Para que eles possam pintar só dentro para melhorar a coordenação, mas com computador é bem mais fácil.

\section{P: Primeiro vocês usam uma criatividade também?}

R: É... Na educação especial, de um modo geral, a gente acaba... Pelo menos até o... O quarto ano a gente adapta muito material. Muito material mesmo né? A gente trabalha muito a questão do visual né? Do visual com a criança... Então vem o computador que nesse sentido ajuda muito como jogos de alfabetização né? Eles gostam. Então basicamente as crianças do primeiro, segundo, terceiro, quarto... Elas ainda não foram alfabetizadas né? Então esse material ajuda muito.

P: É... É... No atendimento aos alunos com deficiência intelectual, propriamente dito, é... Nesse aspecto qual o material que mais tu sentes falta para poder dar um atendimento melhor a eles? 
R: Olha, os jogos é... Eu, por exemplo, o... O bloco lógico, o tangram né? Porque a gente acaba trabalhando a questão de forma, cores e... Tamanho... Você acaba é trabalhando a questão do... $\mathrm{Da}$, da... Da construção de figuras né? Então essa questão do desenvolvimento do raciocínio da criança ela perpassa pela questão desses jogos, do manipular esse... Esses jogos né?

\section{P: Sim...}

R: E aí o... Esses materiais assim... Eles são muito importantes. Jogos de encaixe, por exemplo, o lego que a gente chama... Não sei se ele tem um outro nome... Ele é muito importante naquela questão da coordenação motora. $\mathrm{O}$ aluno ele desenvolve bastante né? $\mathrm{O}$ intelecto dele. E na verdade a gente trabalha a questão das habilidades. E aí algumas... Alguns... A gente tem muitas dificuldades como os professores, principalmente do quinto ano, porque eles querem que a gente dê reforço escolar né? Que não é bem isso que a gente quer. Isso seria uma consequência... Mas o caso né? A nossa prioridade no AEE é o desenvolvimento do aluno né? De uma forma mais ampla, não só o domínio da leitura e escrita né? Mas por exemplo a gente trabalha com eles é... Atravessar a rua, o ir e vir para casa... E isso pra eles... Parece pra gente que é muito simples, eles acham que não é necessário... Existe uma série de cuidados que a gente tem que trabalhar com eles...

\section{P: Para dar uma autonomia?}

R: É... A questão da Autonomia.

\section{P: E a socialização também?}

R: Isso.

\section{P: Tu trabalhas muito com isso?}

R: Sim, por exemplo, é... Nesses últimos... Nesses últimos meses que a gente não tinha espaço é... A gente fazia as atividades na sala de aula né? Aí então quando eles vêm para minha sala o quê que eu procuro? Procuro trazer um aluno né? Um aluno típico, no caso, que não é 
deficiente para realizar atividades junto com eles né? Para que eles possam se ajudar. Eu acho que isso, às vezes, funciona mais do que eu intervindo. Já percebi, por exemplo, quando um colega ajuda, quando ele socializa... Né? Uma dificuldade muito grande são as aulas de educação física né? A gente... Se... O professor da Educação Especial não estiver lá, ou o professor da sala, eles raramente participam. A gente tem que estar lá porque eles precisam de um incentivo maior né? Como eles são muito retraídos... Aí eles não, não... Então você precisa colocar eles no time né? Dizer: não... Qual é o lado que você quer jogar? Você quer jogar? Aí você tem que incentivar eles né? Nesse sentido... Para que eles possam participar das atividades. E aí sempre nas atividades da escola eles têm que participar. Por exemplo... É... Agora vai ter a banda né? Então a gente passou pela casa das mães solicitando que eles participassem né?

\section{P: Tá bom...}

R: Né? Porque eles podem... Possam participar da vida dentro da escola.

\section{P: Então agora no desfile do... Do 4 de setembro, possivelmente eles... Vai ter...}

R: Possivelmente eu acho que o Alexandre vai. A mãe dele ficou de conversar com ele. Porque ele... Ele tem um certo talento para música né? E ficou de conversar com ele para ver se ele vai participar ou não. Mas a gente está na esperança de que... Conversamos com a mãe, conversamos com o avô dele. Que mora... Ele mora com o avô. Para que ele participe. Porque isso é importante para ele.

P: Tu notas a... Principalmente esses alunos que vem do início, do primeiro ao terceiro ano, que são mais crianças né? Na idade de alfabetização... O quê que tu tens notado assim? Tanto em relação a esse primeiro contato dele com a escola regular, como também essa questão da socialização, ou também da aceitação, ou não, dos outros que não tem deficiência...

R: Olha... Nesse primeiro momento aqui é... Eu quando cheguei... Até hoje eu ainda não tenho uma relação completa de todos os alunos né? Mas desses alunos que chegaram...

\section{P: Que tu tens observado...}


R: Né? Eu observo em sala de aula é... Na verdade... Eles têm muito pouca aceitação dentro da sala de aula. Então é mais a gente. Por exemplo, o professor ou a professora... A gente vai lá e faz as brincadeiras né? Para que esses... Eles possam interagir, mas, por exemplo, normalmente você diz... Numa brincadeira para que cada um escolha seus pares sempre os alunos com necessidades eles sobram né?

\section{P: Entendi... Ninguém quer ficar com eles?}

R: É. Então...

\section{P: Assim... Espontaneamente...}

R: Isso. Então o quê que acontece? Normalmente a gente tem que fazer uma intervenção né? $\mathrm{Eu}$ fiz um projeto para que a gente passasse nas salas falando dessas questões né? Da Educação Especial que... É... Hoje a gente é um normal né? Mas amanhã a gente nunca sabe. Então será que a gente gostaria de passar pela rejeição né? Que a gente provoca ao rejeitar o outro na brincadeira e que isso traz alguns problemas né? Então... Mas a gente percebe que isso infelizmente ainda é bastante significativo né? Até mesmo no ensino fundamental maior eu percebo que há.

\section{P: E os familiares nessa relação?}

R: Olha... São assim poucos os familiares que vêm à escola né? É aquela coisa que a gente tem que ir fazer a visita, dizer que tem que vir à escola e eles são bastante ausentes. Bastante ausentes. A grande maioria, mas...

\section{P: E na garantia de os alunos virem né?}

R: Pois é! É aquela coisa: para garantir que o aluno venha, às vezes, a gente tem até que usar de uma certa persuasão né? Falar mesmo que... Do direito. Porque tem... Há pais ainda que preferem que ele fique em casa né? E é aquela coisa que se acha que ele não vai aprender... Ainda aquela coisa do... Do ler e escrever, dominar aquelas operações matemáticas... São fundamentais né? Mas eles valorizam ainda mais isso do que a questão da socialização, do 
estar na escola, de desenvolver, por exemplo, outras habilidades... Como segurar um copo, ou uma caneta né? Ao sair da porta não ficar se esbarrando nas coisas... Então essas coisas ainda elas não são valorizados na escola. Até porque a gente tem pouco tempo aqui também né? Eu não sei se isso se perdeu na escola durante o tempo que a professora... Com a ausência da professora...

\section{P: Da professora Dora?}

R: Isso. Porque assim... Com alguns pais que eu conversei sempre é... Eles ressaltam a importância do trabalho dela né? Na... No desenvolvimento dos filhos. Aí eu não sei te dizer se isso se perdeu. Porque é um trabalho contínuo... Típico...

\section{P: Então vai ter que resgatar?}

R: Tem que resgatar...

\section{P: Ou até construir algo novo... Em cima do...}

R: É... Até porque já é uma outra demanda né? Pelo que eu percebi, por exemplo, dos alunos dela. Tem vários alunos que já estão no ensino médio. Então a gente vai dar um suporte né? Mas a gente percebe que eles conseguiram avançar. As pessoas falam que o trabalho dela foi muito significativo né? Mas eu acho eu acho que se perdeu com essa ausência, essa lacuna... Aí eu acho que durante uns três ou quatro anos, não sei bem... Porque assim eu tenho material dela até o dia... Até, até 2010 eu encontrei né? Então é por isso que eu te falo que eu acho que ela deve ter saído no final de 2010 para a aposentadoria, ou alguma coisa do gênero. Mas a grande luta mesmo é trazer. Por exemplo, na reunião da Educação Especial que eu sou... Disse ter e ia... Veio apenas um né? Uma mãe veio na reunião. Aí é... As visitas mesmo nas casas são as coisas mais constantes... Trazer, chegar lá e dizer que tem que vir à escola. Uma coisa muito importante, por exemplo, que eu acho: é o pai vir buscar o aluno na escola. Ainda que ele não venha trazer, mas ele vir buscar né? Cria este laço de importância para eles... Do cuidado e tudo mais...

P: O... Deixa eu te perguntar... Em relação à... É que eu conversei com a professora de lá... De... A professora Kátia, lá de Urubuoca, e ela me falou exatamente isso. Que ela 
ainda observou e ela tem conhecimento que ainda tem muitos alunos que... Com deficiência, principalmente intelectual, que estão dentro de casa, que não chegaram lá... Que existem, mas não estão devidamente matriculados.

R: É isso...

\section{P: Tu tens reconhecimento disso?}

R: Sim, sim... Aí a gente... Se eu não me engano... Porque tem uma lei que diz que o pai né?

P: É...

R: Ele não é obrigado a trazer para o atendimento...

P: É... Mas ele seria obrigado sob pena de caracterizar abandono intelectual...

R: É... Aí... Mas aqui a gente trabalha com a questão da escola né? E ainda que o atendimento educacional não seja obrigatório, o AEE, mas a questão do aluno na escola...

P: É...

R: Né?

\section{P: No ensino fundamental...}

R: No ensino fundamental. E aí a gente vê isso, mas... É... Eu vejo mais na questão do DMU sabe? Aquela aluna que a gente estava... Aquela mãe que a gente estava falando né? Aí já é uma adolescente, acho que ela já tem 17 anos... Aí já fica mais difícil, mas nas crianças, normalmente quando a gente identifica né? Apesar da COEGE agora colocar... Haver colocado uma pequena barreira para a gente, mas a gente identifica, a gente faz avaliação e o atendimento né? E a ideia é... Quando a gente orienta o professor: percebeu? Né? Sabe de alguém? A gente vai, faz a avaliação e exige a matrícula do aluno. Né? 


\section{P: O... E como é esse seu contato com o professor? Da sala de classe regular... Existe uma resistência deles? O quê que tu tens notado?}

R: Não são todos. Na verdade tem alguns professores que eles até solicitam que eu vá à sala. Né? Eu tenho... É... Um ou outro que tem resistência. Nos anos iniciais eu acho que... Que isso praticamente não existe... Né? É mais do sexto ano em diante...

\section{P: Do primeiro ao terceiro... Nessa parte da alfabetização?}

R: Não. Eu não percebo isso. Na verdade há uma solicitação de você estar lá. A dificuldade é... Por exemplo, eles dizem: ai me ajuda lá porque eu não sei como agir né? Eu sempre... Eles sempre solicitam esse tipo de ajuda.

\section{P: Mas eles não chegam propriamente a rejeitar o aluno?}

R: Não. Eu nunca percebi isso. Nunca percebi. Eu acho que há a questão da angústia. A angústia de: o quê que eu vou fazer? Porque, às vezes, assim... Chega o aluno e aí você não está preparado né? Eu sempre digo: mas nem eu estou preparado. Aí eu chego...

\section{P: As mães não são preparadas. As mães não são preparadas para ter um filho assim...}

R: É. E aí eu digo: não! Se acalme! Não é um bicho de sete cabeças, a gente vai dar um jeito. Né? Aqueles que têm problemas comportamentais então... São os que mais chamam atenção porque na verdade a gente não quer um aluno, a gente quer, como professor, um aluno quieto. Essa é a ideia. Então esse estranhamento da chegada é o que mais dá... Né? Dá... Causa mais problemas assim.. Mas eu não percebo assim que os professores rejeitam o aluno. Eu percebo que a formação deles faz com que causa um estranhamento na hora da chegada. Porque com o tempo... Nesses... Efetivamente eu estou no início de 2014 né? Então depois desse... Dessa chegada... Que é um pouco tumultuada para o aluno que vem sai de casa, dentro de um ambiente totalmente diferente... Chega da escola né? Onde já tem regras pré-estabelecidas e tudo mais... Que há esse estranhamento... É o momento mais dificultoso né? Aí... Descobrir o que esse aluno gosta para chegar até ele é mais complicado. Mas eu acho que a partir dos três meses né? Essa relação ela se torna uma relação normal. De um aluno travesso na escola, daquele que, às vezes, não quer fazer o trabalho, mas também daquele aluno que... É... É... 
Chega algum dia e quer fazer a atividade, como qualquer um outro né? Não, não... Eu vejo... Por exemplo, a questão... Em determinada turma você tem três alunos né? Aí isso eu acho que causa ou estresse muito grande para o professor né? Isso a gente percebe bem na fala deles porque tem... Porque quer ter não queira no final do ano esse professor ele vai ter que dar conta da aprendizagem de todos os 30 né? Então eu acho que essa seleção ela tem que ser... Essa matrícula ela tem que ser melhor pensada né? $\mathrm{Na}$ hora de colocar os alunos, enturmar os alunos... Para que umas turmas não fiquem com mais e outra sem.

P: Para... Assim... E em relação, por exemplo, essa realidade aqui de Cotijuba, principalmente da escola Marta da Conceição que tem dois anexos né? Então você vê que tem problema de acessibilidade nas escolas é... Alguns alunos necessitam do transporte fluvial... É... Às vezes as condições do transporte desses alunos... Isso de uma certa forma gera uma dificuldade do acesso deles. E essa questão ambiental né? Do fato de você ter o atendimento, por exemplo, em Urubuoca, de cinco ilhas né? O que é que tu observa em relação aos alunos com necessidades educacionais especiais?

R: Essa questão do transporte ela é um dos fatores principais das ausências das crianças da Educação Especial né? Nas ilhas. Por exemplo, para uma mãe é muito difícil ela mandar um filho para escola pela manhã num barco onde ele passa... Sei lá... Seis horas dentro do barco e voltar com ele à tarde para o atendimento educacional especializado. Ou então ele sair daqui de manhã, por exemplo, no caso do Geison, ele vinha para a aula de manhã e o atendimento dele era à tarde. Só que esse bonde ele vem com o Geison tá? E ele só vai voltar seis da tarde. Então o Geison ficava o dia todo na escola, porque ele chegava lá almoçava e voltava né? E aí quando não tinha outros alunos eu ficava com Geison direto né? Mas assim... Por exemplo, os dias que eu tinha que fazer atendimento com três, quatro alunos... Aí ficava muito difícil a situação do Geison. Ficava na escola o dia todo. Aí eu ficava pensando: será que ele almoçou?

\section{P: Sei... A escola não tem isso atendimento integral?}

R: Né? Não tem né? Não tem. Até porque eu não sei como é que vai ficar agora, mas nós temos um número muito maior que... Do que a gente pode atender. São... É... Era... No caso são... A demanda são para professores de... Dois professores de 200 horas. Aí tem eu com 200 e a Roseline com 100 né? Aí então a gente... A gente faz um... Tem dias que eu atendo de três alunos. Porque se eles chegam à escola não tem como eu dizer para esse aluno voltar. Não 
tem. Não vou dizer... Como que eu vou dizer para um aluno, sei lá, que vem Paquetá, que não vai ter o atendimento para ele naquele dia...

P: Paquetá tem quanto? Para se deslocar da Ilha de Paquetá para cá dá quanto tempo?

R: Olha... Depende muito... Mas leva uma hora, mais ou menos... Como daqui para Urubuoca.

P: Então o aluno chegou aqui e não tem como tu...

R: Não tem como. Não tem como eu dizer para ele que ele não vai receber o atendimento. Mesmo que o atendimento seja individualizado naquele dia né? Apesar da gente colocar outros alunos... Mas o foco nosso é o aluno Educação Especial né? E aí no dia que vem esses alunos né? Como o Geison que ele vinha... O Geison vinha todos os dias. Aí tinha que ficar com ele né? E aí há momentos assim bem... Bem conflitantes. E mais: essa questão do transporte ela ainda é muito prejudicial a esse atendimento da Educação Especial.

P: E uma... Um outro aspecto também que eu observei é a questão do... Em relação a... A esse atendimento... É... É o calor agora que está...

(Risos)

R: Tu imaginas lá naquela... A gente atendia lá naquela sala... Lá atrás, onde está a merenda...

P: Ah sim...

R: Nesse calor...

P: No site do MEC diz que aqui tinha é... Aula de Libras... Tinha outros atendimentos... Né? Quer dizer... Fora o atendimento da Educação Especial, não tem cursos extras? Para os alunos... Curso de Braille... Essas coisas... R: Não. Não.

\section{P: Neste momento não tem?}


R: Não. Não tem. Até porque assim... É... A minha formação na educação especial é DI mesmo né? É direcionada para DI.

\section{P: Soroban? Essas coisas...}

R: Não. Não tem. Então, por exemplo, o Braille eu domino o básico que é a minha leitura visual sobre o material. Por exemplo, eu não consigo fazer a leitura do Braille nos dedos como... Né? O deficiente visual faz. Eu não consigo. A minha leitura é visual.

\section{P: Sim...}

R: Né? É...

P: Então... Ou seja, além da sala multifuncional não estar funcionando né? Nesse momento... Não tem esses outros cursos?

R: Não.

\section{P: De suporte...}

R: Não tem. Até porque precisaria... Por exemplo, a gente está solicitando um professor de Libras. Específico, formado na área de Libras. Para que ele possa acompanhar os alunos do quinto ano... Do quinto a... Do sexto ao oitavo... À... Ao nono ano.

\section{P: Certo.}

R: Porque eles precisam né? São...

\section{P: Sim.}

R: Aquilo que te... Falei para a mãe ali... Por exemplo, matemática eu não sei como repassar em Libras. É uma deficiência minha. Eu acho que não aprendi pra mim... E aí em Libras mais difícil ainda. Mas português eu consigo... Mas... Isso precisa de um professor na sala de aula. Porque mesmo que eu faça esse atendimento no AEE não tem como eu estar continuamente, 
pelo menos uma vez, nas aulas de matemática, de português e das demais disciplinas dentro da sala de aula...

P: Mas os professores dialogam contigo sobre a... Alguma necessidade que o aluno tenha na matéria e que exige alguma estimulação na... No contraturno assim... Nem... Principalmente nesse aspecto do deficiente intelectual.

R: É...

P: E que tu possa intervir dentro das suas atribuições...

R: Isso. Sim, sim.. Otha, por exemplo, sempre a... Tem alguns professores que... Dos anos iniciais... Que quando eles vão trabalhar em sala, por exemplo, eles perguntam: o quê que tu acha dessa atividade? Dá para trabalhar com determinado aluno? Né? Então ele sempre fazem esse tipo de pergunta...

\section{P: Em relação ao deficiente intelectual?}

R: Pois é! Em relação a eles principalmente né? Aí... Olha vou fazer tal atividade... Tu achas que... Que eles vão conseguir participar? Aí outras vezes é... A gente acha que é... Tem como adaptar essa atividade para eles? Para os alunos com deficiência. E aí a gente vai trabalhando isso... É... Nas séries iniciais isso acontece bem, bem legal... De forma bem legal.

P: Aquela relação de alunos que tu me deste... É... Tu faz esse tipo de abordagem? De atendimento diferenciado? Então... Para eles...

R: Sim. Naquela relação. Mas é... Eu coloco no PDI, eu não coloco naquela relação.

\section{P: Sim.}

R: Quando o computador prestar eu vou te mostrar o PDI. Eu acho que quando voltar ele já vai estar... Aí no PDI a gente coloca as atividades que a gente trabalha... É... O PDI é o plano... Plano de Desenvolvimento Individual do aluno. Então para cada aluno é desenvolvido um tipo de atividade. Até mesmo, por exemplo, uma questão simples... Do jogo da memória 
ou quebra-cabeça que a gente trabalha com aluno surdo não é o mesmo que a gente trabalha com o aluno DI né? A deficiência intelectual né? Então, às vezes, o mesmo material que você confecciona serve para os dois, mas outras vezes... Nem sempre né? E aí a gente... É o pessoal da... Das salas... Eles sempre estão atentos a esse tipo de situações né? O pessoal das séries iniciais. Aí do ensino fundamental maior que já é um pouco mais complicado né?

\section{P: Deixa eu ver se tenho mais um questionamento para ti... Pode ser que essa mulher da manhã... Mas... É... Tu terias alguma coisa mais a dizer nesse aspecto do atendimento desses alunos? As dificuldades de estrutura... O histórico da escola que tu lembras...}

R: Olha... Assim... Na verdade eu vejo que a escola ainda... Nós ainda estamos numa forma embrionária né? A gente não está nem engatinhando na Educação Especial aqui na ilha né? É... A gente tem o número de alunos ainda que vai para outras unidades né? Que a gente não tem vaga. Para... Vão para outras localidades... Como Icoaraci... É porque a gente também não tem uma estrutura para que possa atender esse aluno com dignidade. Por que... É... Mesmo que você tenha uma pequena sala, às vezes, você precisa... Precisa de uma estrutura maior. Nós não temos, por exemplo, na escola... Não tínhamos um banheiro adaptado, por exemplo... Alunas maiores, por exemplo, a gente precisa de um cuidador. Eu não posso entrar no banheiro com uma aluna. Então normalmente eu chamo uma professora da sala né? Da sala regular né? Então são essas pequenas coisas assim... A escola não... Não tem um banheiro para a Educação Especial né? Eu acho que é uma coisa muito importante pela questão da singularidade de cada um deles né? Eu vejo que eles não poderiam usar o mesmo banheiro que todos os demais alunos usam né? Acho que é uma questão muito... Muito particular da Educação Especial né? Eu acho que a questão do cuidador ela é imprescindível né? Para gente estar trabalhando na Educação Especial de forma mais... Mais articulada. E a questão mesmo da... Do inserir o aluno dentro de todas as atividades da escola né? Eu acho que a escola tem que pensar o aluno da Educação Especial como todos os outros alunos. Um aluno que pode tocar, um aluno que pode participar dos jogos estudantis da escola...

\section{P: Isso ainda não é uma realidade?}

R: Isso ainda não é uma realidade. É aquela... É aquela coisa assim: o professor da sala de aula ou professor do atendimento educacional tem que estar lá. Como que eu te diria? Tipo que empurrando o aluno. Porque ele é sempre rejeitado... 


\section{P: Sei...}

R: Né?

P: A estimulação tem que ser feita não só em relação ao aluno, mas em relação ao professor?

R: Ao professor... É uma questão de formação né? Nossa formação...

P: E dos outros alunos que não têm deficiência...

R: E dos outros alunos também. É a questão da formação da escola. Por isso que eu te falo que isso é uma questão embrionária né? Ainda precisamos fazer muitas palestras e... Para que isso possa acontecer dentro da escola.

P: Tu sente um pouco essa rejeição tanto em relação aos professores como em relação aos outros alunos e familiares de quem não tem deficiência?

R: Sinto. Percebo isso muito bem. Assim... Quando eu acompanho meus alunos nas atividades aí eu noto né? E eu procuro sempre desarticular. Mas aí você já percebeu né? Aqui... E, às vezes... É... Muitas das vezes eles percebem também e aí ele se retraem mais ainda...

\section{P: Entendi...}

R: Né? Outras vezes eles... Quando eles estão na atividade... Eu até disse uma vez para a professora que eu não ia mais participar. Porque quando você vê eles olham logo pra você né? Aí... Querendo dizer: por favor, encontre um lugar para mim aqui né?

P: E tu particularmente? Assim... Dentro dessa coisa... Tu acreditas que... É... Que haja uma esperança dessas coisas mudarem? Tu acreditas na educação inclusiva?

R: Sim. Acredito. Eu acredito porque eu vejo... Assim... Resultados...

\section{P: Positivos?}


R: Positivos. É... Não é... Eu digo para os pais: o que vocês querem hoje é que os alunos, que os filhos de vocês desenvolvam-se como todos os outros pais querem. Mas pense que para eles... Eles têm uma barreira a mais. Essa... Na medida em que essa barreira ela é superada né? Para eles é um grande... Um ganho muito bom né? Então eu vejo assim... Quando um aluno é, por exemplo, O Geison, quando ele chegou e mostrou para mim: essa palavra é bala? $\mathrm{Eu}$ fiquei muito feliz né? Disse: é bala. Né? Porque é algo assim... Que essa leitura e essa escrita que é mais cobrado da escola... É... E que também a gente cobra deles né? É... Ela é... Dado é... Dado muita ênfase. Exageradamente na Educação Especial. Porque eles querem que a gente dê o reforço né? E a gente ajuda. Claro! Mas eu acho que tem muitas outras coisas... Muitas outras habilidades questão por trás... Que são interessantes né? E eu vejo que na Educação Especial a gente já está de forma embrionária, mas a gente está caminhando. Eu acho que isso vai melhorar, eu já vejo resultados positivos.

\section{P: Isso dá uma esperança então?}

R: Dá. Eu acho que falta assim... Uma questão de organização ainda né? De sistematizar... E eu vejo, por exemplo, que nós precisamos de mais profissionais, nós precisamos buscar mais informação né? Por exemplo, desde que eu entrei eu participei da formação inicial da Educação Especial. Oferecida pelo governo.

\section{P: Iss o foi quando?}

R: Foi... Acho que foi junho de... Ou setembro. Não. Foi agosto de 2013.

\section{P: E de lá para cá tu não tiveste?}

R: De lá para cá não. Eu fiz um curso de...

\section{P: Nem receberam nenhum... Um boletim? Nada? Nesse aspecto?}

R: Assim são cursos... Assim, por exemplo, de autismo, mas a gente que vai atrás...

\section{P: É por tua conta?}


R: Né? Tudo a gente que faz.

\section{P: Mas institucionalmente não?}

R: Institucionalmente...

\section{P: Não houve...}

R: A própria COEGE, por exemplo, não lembro de oferecer um curso. Eu acho que é uma coisa que a gente deveria estar fazendo regularmente.

\section{P: Até online mesmo né?}

R: Né? Com certeza. Eu acho que nós deveríamos também ser avaliados. Eu acho que é... É... As pessoas dizem que são já professores, mas eu acho que nós deveríamos ser avaliados dentro do nosso trabalho. Eu acho que tudo... Tudo tem que ser avaliado para que a gente possa redirecionar, rever o que está sendo feito né? Porque hoje em dia você ter avaliação é cobrança. Mas eu vejo avaliação é bem diferente né? É o olhar aquilo e ver o que você pode melhorar. Então eu ainda penso que a gente precisa melhorar nesses aspectos. A nossa formação né? Dessas questões estruturais... Fazer com que o aluno tenha o acesso à escola. Fazer com que o aluno se sinta parte da escola. É como... Como um todo mesmo né? Que o aluno possa chegar e que ele possa participar das aulas de informática, de educação física, de artes... Que ele possa participar das pesquisas de laboratório da escola. Para que ele possa fazer parte de todas as atividades. Eu digo: o aluno especial ele tem que ser visto como um aluno normal. Ele tem que ser visto como um aluno normal. E aonde ele apresentar dificuldades, como todos os outros alunos têm, aí a gente vai fazer a... A intervenção né? Que aí a gente vai procurar o que é... Ver o que é melhor para ele. Mas ele tem que ser visto como normal. Dentro deste aspecto...

P: Ok. Obrigado Batista. Então a gente encerra por hoje a nossa gravação para a pesquisa aqui da UnB. E qualquer informação a mais a gente entra em contato com você. 


\section{ENTREVISTA}

Data: 24 de agosto de 2015

Local: Escola Estadual Marta da Conceição - Cotijuba - Distrito de Icoaraci - Belém / PA

Entrevistada: Silvânia Gomes da Silva

\begin{tabular}{l|l}
\hline SÍMBOLOS & LEGENDA \\
\hline $\mathbf{P}$ & Pergunta ou fala do entrevistador \\
\hline $\mathrm{R}$ & Resposta ou fala do entrevistado e demais participantes \\
\hline Itálico & Compreensão duvidosa \\
\hline (0min 0seg) & Trecho não compreensível \\
\hline$\ldots$ & Pausa na fala \\
\hline
\end{tabular}

\section{P: Pronto. Sim...}

R1: O... O meio assim... Dele... Antes dele... De ele começar assim...

P: Primeiro coloca o teu nome, o nome dele... E o nascimento dele, quando foi que ele nasceu...

R1: O meu nome é Silvânia Gomes da Silva né? E o nome do meu filho é Geison Silva do Nascimento. Ele nasceu dia... Foi dia 31 de Março de 2003. Que ele é né? Então assim... Quando meu filho nasceu né? Foi... Para falar a verdade desde o começo foi uma complicação muito grande. A minha gravidez do começo ao fim foi muito complicada. Então... Só que através das complicações eu jamais na vida pensava que fosse chegar a um ponto desse assim de um dia... Eu jamais pensaria que um dia eu fosse ter um filho especial. Eu via muitas mãe, eu conversava com muitas mãe que tinha filho especial... Aquelas outras mães que tinha... Que as crianças já nascia com aquele... Aquela especialidade chamada Síndrome de Down né? Mas jamais na minha vida passaria assim na... Na minha imaginação de um dia eu poder passar assim por uma situação dessas assim também. Lidar com uma criança especial. Pelo fato de eu ouvir as outras mães falar para mim era uma coisa impossível. Jamais. Poderia acontecer com qualquer outra pessoa menos comigo. Porque assim pela maneira que eu vejo, às vezes, assim.. É uma situação complicada. Já é complicado hoje em dia você cuidar de 
uma criança normal imagine você cuidar de uma criança que tem uma especialidade e é diferente das outras crianças né? Então é uma responsabilidade muito maior...

\section{P: Ele nasceu com que tipo de deficiência?}

R1: Ele... A deficiência dele já veio... Já veio ser...

\section{P: Diagnosticada...}

R1: Diagnosticada já na idade já dele de seis meses. Foi. Porque quando ele nasceu ele já nasceu com um problema né? Ele desmaiou. No momento que... Que eu tive ele. Aí ele ficou a faixa de uns 5 minutos sem respirar. Eu tive meu filho ali, em alguns minutos nos meus braços, como morto. E eu... Como é que se diz? Como era o primeiro filho também né? Estava muito debilitada pela situação que eu tinha passado... E aí foi que eu tive ele no hospital São Lucas, ali em Icoaraci. Foi quando eu tive ele. E aí foi quando... Também ele voltou... As Enfermeiras pegaram ele, o médico pegou ele e pronto. Disse que estava normal. Ele voltou novamente... Aí pronto. Quando... Com seis... Foi. Com seis meses em diante já... De um ano já... De 6 meses a 1 ano tudo perfeito. Tudo perfeito. Uma criança gordinha, uma criança coisa mais linda. Bem branquinho... Ele sempre foi forte ele... Tudo. Já vinha mesmo perceber essa... Essa deficiência dele já na idade de três anos em diante. Aí o médico me falou que esse problema dele tinha sido falta de oxigênio no cérebro dele quando ele nasceu. Como ele desmaiou né? Teve esse problema nele. Aí pelo momento, pelos minutos que ele passou desacordado, que ele não foi socorrido na hora. Aconteceu esse problema de ter atingido a metade do cérebro dele.

\section{P: Então ele tem uma deficiência intelectual?}

R1: Isso. Exatamente.

\section{P: Ou seja, ele tem uma dificuldade no aprendizado?}

R1: No aprendizado. Ele é uma criança assim... Ele está com 12 anos.

\section{P: Outras atividades da vida diária ele tem alguma dificuldade?}


R1: Para falar a verdade todas as... As atividades... Ele não se bota para fazer nada. Eu que tenho que estar em cima todo o tempo. Eu que tenho que estar... Estar ativando ele. Tenho que estar falando...

\section{P: Quais são as características dele?}

R1: As características dele é assim.. Ele é uma criança muito calma. Ele chega com você, ele fala com você. Ele é muito amigo, ele é muito alegre...

\section{P: Ele fala?}

R1: Ele fala. Ele é muito perguntador.

\section{P: Sim...}

R1: Muito perguntador. E aí.. Só que assim... Chega a crise. Quando dá nele ele é muito nervoso. Ele começa a chorar, ele quer estar sozinho... Ele se isola dos outros irmãos... Que eu tenho mais dois filhos né?

\section{P: Certo.}

R1: Além dele... Então ele quer estar sozinho, no canto dele... Ele não quer... Quando ele está dessa maneira assim... Que ele está com essa crise... Ele não quer contato com ninguém. Se ele pudesse se isolar mesmo, sozinho mesmo, sem ninguém olhar para ele... Tudo aborrece ele. Aí se você for para... Como é que se diz? Para conversar... Ou então se você começar a falar em um tom mais alto com ele... Ele vai... Chega até a ficar agressivo... Aí foi que da idade já dele de... De... De três anos em diante... As pessoas perguntam... Me perguntavam se ele tinha problema... Eu disse: não. Eu cheguei até a me aborrecer com várias pessoas. As pessoas perguntam... Olha: seu filho tem problema? Eu disse: não, meu filho é normal graças a Deus. Não, mas tu já pensou na possibilidade do seu filho ser especial? Isso e aquilo... Tu pode correr atrás dos direitos do teu filho... Eu me aborrecia com as pessoas. Eu disse: olha eu acho melhor vocês tomarem de conta da vida de vocês e deixarem a minha e a dos meus filhos de mão... Assim.. Porque é uma coisa assim... Logo de primeira... De primeira vista assim você não quer aceitar. É fácil você ver na familia de alguém, mas na sua familia às 
vezes é difícil. E eu ficava assim.. Foi que depois de muitas insistências das pessoas e tudo... Aí eu comecei a ir mais adiante né? Aí foi que eu comecei. Ele começou a fazer um tratamento e tudo. Levei ele para Belém. Aí começou... Foi que bateu a chapa lá. Aí na chapa foi que atestou que ele era realmente especial e que ele tinha essa dificuldade. Aí foi que a psicóloga lá me falou... A Psiquiatra. Ela me falou que a possibilidade dele é... Ele tem $70 \%$ de desenvolver conforme o crescimento dele... Dele desenvolver... Voltar a ser uma criança... Uma pessoa adulta... Uma criança. No futuro ser uma pessoa adulta, um homem... Adulto né? Ter os pensamentos mesmo. Desenvolver os pensamentos dele, a mentalidade dele... E também $70 \%$ dele não desenvolver. Ficar sempre... Ser um dia, no futuro, ser um homem, mas sempre com a mentalidade de criança. Porque ele está com 12 anos, mas a mentalidade dele é de uma criança de três anos... De quatro anos...

\section{P: Ah... Entendi...}

R1: Então é dessa maneira que ele reage. Assim... Para ele... Ele não vê assim... Maldade em nada. Ele não vê perigo em nada... Ele... Como é que se diz? Se ele for tomar um banho ele vai e ele tira a roupa na frente de todo mundo... Para ele tudo é normal. Tudo é perfeito... Então eu tenho que estar em cima dele ali todo o tempo. Não meu filho, não é assim... É dessa maneira assim... Então para ele tudo está perfeito. Então é uma criança assim... Que é muito fácil de você levar. Se você chegar e você diz: faz isso ali... Por mais que para outra criança na idade dele saiba que aquilo ali não pode se fazer para ele, ele faz... Para ele que é a coisa mais normal do mundo. Então pra mim assim se torna um pouco complicado né? Mas graças a Deus eu tenho levado, eu tenho conseguido através dos médicos também... Que ele tem feito é... O tratamento. Também muito apoio também... Ele... Ele vive também a base de medicamento. Que ele toma o medicamento dele. E graças a Deus. Às vezes é difícil, não vou dizer... Que às vezes é difícil principalmente que ele já está ficando já... Entrando já na fase da adolescência né? E tá como eu digo assim... Até que quando é uma criança você tem mais a possibilidade de você lidar assim mais... Mais assim.. Como eu posso dizer assim? É mais simples de que você chegar... Como é que se diz? Uma fase vai chegando... A fase já da adolescência, vai chegar à fase adulta e vai ficando mais complicado. E para minha assim complica por quê? Porque a única voz autoritária lá em casa é a minha. O pai... Na... Ele com a idade de sete anos o pai foi embora. Aí então eu tenho que ter a voz do pai e a voz da mãe ao mesmo tempo. Tem hora que ele chega a engrossar a voz para o meu lado. Mando ele fazer algo, mando ele... É... Como é que se diz? Se ele está fazendo algo de errado o que eu vejo 
que não está certo eu falo com ele... Ele vem, ele grita em cima de mim. Só que é aquilo... Eu não chego a me... Me... A ficar... Como é que se diz? Não chego a temer para ele. Mostrar que eu estou com medo... Isso e aquilo... porque é uma coisa que a médica lá... Quando eu vou levar ele para fazer o acompanhamento ela conversa muito comigo sobre esse ponto aí... Né? Ela disse: jamais! Porque aí está chegando uma... Ele está chegando em uma idade mais avançada. Ele está amadurecendo. Então vai chegar uma época dele estar com 18 anos, 19 anos... 20 anos! De você falar com ele e ele vir gritar em cima de você e você não tem que mostrar o semblante de medo para ele. Sempre você tem que mostrar o semblante de autoritária. Quem grita ali é você. Aí ela me pergunta como é que eu trato ele. Eu trato ele como... Como se eu tratasse meus dois filhos. Eu não trato ele com indiferença. Dizer: não, eu trato os meus dois filhos assim e trato ele dessa maneira. Não. Eu trato ele... Por que... Como eu digo: apesar dele ter essa especialidade, mas ele é normal como os outros. Não tenho como motivo de eu tratar um melhor e tratar os dois diferente. Não. Ele tem que ver que ele é igual todo mundo. Era uma diferença muito grande quando ele chegou aqui no colégio.

\section{P: Sim...}

R1: Foi muito difícil ele se adaptar aqui.

\section{P: Qual foi... Ele veio com que idade para o colégio?}

R1: Ele veio para cá com sete anos.

\section{P: Como foi que vocês definiram que ele viria para o colégio?}

R1: A maneira de eu definir para ele vir para o colégio... Porque assim... Na verdade ele começou a estudar desde três anos, mas particular. Só que eu não morava aqui. Eu morava em Icoaraci né? Aí então desde a idade de três aninhos eu botei ele no colégio. Colégio particular e tudo. Então quando eu vim me embora para cá ele já estava já na idade de 7 anos. Aí foi que eu coloquei. Eu tinha até medo de colocar ele no colégio público. Por justamente esses motivos. Porque os outros moleques são mais peraltas... Isso e aquilo... E ele de não ter essa possibilidade, de não ter essa mentalidade... De malinarem com ele... Como chegaram... Querer malinar com ele... Faziam o dele aqui o que queriam. No bondinho também... Passaram pimenta nele. Os meninos malinavam com ele às vezes e aí eu... 


\section{P: Ele sofreu logo no começo...}

R1: Logo no começo...

\section{P: O bullying...}

R1: Isso. Foi que...

\section{P: Chamam bullying...}

R1: Exatamente. Foi logo no começo que ele coisou... Aí todo dia eu tinha que estar aqui. Eu tinha que vim trazer ele e tinha que vim buscar. Às vezes eu fazia até plantão aqui. Eu cheguei muitas vezes a me aborrecer com os professores e os professores também chegaram a se aborrecer comigo. Que o papel deles era simplesmente de ensinar, não ficar vigiando o filho de ninguém. Eu cheguei até dizer que eu ia procurar os meus direitos porque se eu tinha colocado o meu filho no colégio... Não para ser malinado por ninguém, mas sim para ter uma melhora para ele. Para ele não está só dentro de casa né? Aí foi que depois já de dois anos que ele estava estudando aqui as coisas foi melhorando e tudo de tanto eu dar... Tá dando em cima. Aí foi que veio ter aula especializada para ele. Que quem... Ele começou com a professora Dora. Foi a primeira professora dele daqui. Aí foi que as coisas foi melhorando... Porque quando ele estava estudando normal mesmo com outro professor, na turma normal, ele não fazia nada... Ele não chegava nem a rabiscar a folha do papel...

\section{P: Entendi...}

R1: Porque o professor não... Porque ele é... Ele tem também um problema é... Coordenação motora né? Ele não é assim... No caso se for para fazer um dever ali ele faz na maior paciência do mundo. Ele não tem pressa para nada. Para ele fazer... Como é a história? Eu digo assim: às vezes ele quer que o mundo pare para ele. Para ele fazer aquilo que ele quer fazer. Porque ele não tem pressa. Então, às vezes, ele vinha para o colégio ele passava de manhã até meio dia... Chegava em casa não sujava uma folha de caderno. Menino o quê que tu estavas fazendo no colégio sem tu fazer nada? Porque quando eu fui fazendo o professor apagava... Porque ele também não ia estar esperando pela boa vontade dele... Aí foi que 
depois que ele começou a estudar com a professora Dora foi que veio melhorando. Porque a... O tempo dela era justamente só para ele e outro... Os outros alunos né? Aí foi que veio melhorando mais. E graças a Deus hoje ele já está... Já faz um bom tempo que ele já estuda aqui. Aí foi que depois a professora Dora veio o professor Batista também. Que ele se dá muito com o professor Batista. E aí então melhorou muito... Agora ele já conhece as letras, que ele não conhecia... Já conhece... Ele já consegue formar as palavras, já consegue ler, já consegue fazer a numeração, já consegue contar... Então ele desenvolveu muito. Depois que desenvolveu essa aula particular aqui... É... É... Com professores especiais para ele... Melhorou bastante. Muito mesmo. Só que ainda aqui, como eu disse... Que aqui ainda há uma dificuldade. Um dia desses eu estava até conversando com professor Batista. Que há uma dificuldade ainda para as crianças especiais daqui. Por quê? Qual é a dificuldade? Principalmente na... $\mathrm{Na}$ área da educação. Porque aqui não tem um... Como eu posso assim dizer? Não tem o material adequado para essas crianças. Porque tem que ser o mesmo material que eles estudam na escola normal... Mesmo na aula normal... Com os outros alunos. E não tem assim ainda um espaço assim... Como eu posso dizer? Assim... Um tempo... O suficiente. Porque o tempo deles é muito pouco. Porque se ele entra no horário de... Queira dizer... Se ele entra no horário de duas horas, o máximo três horas ele já sai. Ele entra uma e vinte, uma e meia... No máximo duas e dez ele já está saindo. Então o tempo é muito pouco. É pouquíssimo. Eu disse: era para ser uma aula mais longa. Com eles... Aí foi que o professor disse: é, mas infelizmente não está no... Não é ao nosso alcance. Não é a nossa vontade. É a vontade dele. A gente faz o que está na vontade... O que eles mandam. Então nessa... Nessa possibilidade ainda... Como eu disse: é uma coisa muito pouca o tempo que eles têm de estar estudando com os professores adequados que seja para eles. E aí então é dessa maneira assim que... Mas graças a Deus. Depois assim que ele começou a estudar aqui ele melhorou bastante. É difícil ainda pra mim. Assim... Dentro de casa... Com ele assim... O fato assim deu lidar com ele. Muito... Em alguns aspectos assim... Mas tirando isso a gente...

\section{P: Quais aspectos?}

R1: Os aspectos assim... Dentro de casa assim.. Com ele assim... Na forma que eu já the falei. Né? Que assim... Que às vezes ele fica... E principalmente na fase que... Quando ele está agitado. Que ele está assim... Agressivo. Eu fico assim... Até um pouco assim... Aí eu pego eu prefiro sair com ele. Passear com ele assim... Porque ele não é... Graças a Deus até hoje ele nunca foi uma criança de querer agredir. Ele fica assim recuado... Um pouco assim... Mas ele 
nunca foi assim ao fato de querer vir agredir... Como lá no... Na... No consultório lá... Quando eu vou levar ele... Já... A gente conversa com outras mães né? Com outras crianças lá. E muitas... A gente escuta muito as outras histórias diferentes. Já rapaz mesmo assim... Então as mães assim... De uma para outra vai contando a situação, a maneira, a convivência... Que convive com os filhos né? E aí então assim... Umas diz que os filhos já chegou a bater, outra diz que o filho já tentou matar... Eu digo: graças a Deus. Nesse... Nesse lado aí eu só tenho a agradecer a Deus. Porque eu acho que apesar da gravidade da situação do meu filho, mas eu acho que não chegou assim... Ser um nível tão grave dessa maneira ainda. Porque logo assim... O motivo assim... Ele gosta também muito assim... Que ele gosta... Porque a gente era da igreja. Né? Então ele gosta muito de estar na igreja...

\section{P: Entendi.}

R1: Aí ele gosta muito de estar cantando hinos. Ele fala que ele vai ser um pastor. Que ele quer ser um pastor e que ele não pode brigar com ninguém. Porque quem é crente não pode desobedecer a Deus. Então ele é uma criança assim.. Muito inteligente por esse lado. Ele gosta muito de música. Deus me livre! Música pra ele... É tudo para ele. Seja tanto evangélico como mesmo música normal... E assim.. Como eu digo assim... É uma coisa assim que ele não sabe discernir uma coisa da outra. Né? Então para ele tanto seja hinos como seja a música mesmo para ele tudo está normal. Sendo música... Tudo tá bom pra ele. Ele gosta muito também o negócio de bateria. Ele sabe todo... Se está tocando uma música que ele vê que está no ritmo da bateria ele sabe todos os ritmos da bateria. Tudinho. Então assim... Por este lado muitas coisas assim... Ele é uma criança muito inteligente. Ele não é uma criança assim de chegar e se expressar. Ele não. Ele é de chegar e observar. Ele chegar aqui ele senta aqui... Ele fica calado. Se for ele... Você vê alguma coisa que ele vê, que ele dá de perguntar para você, ele vem pergunta. Se não ele fica calado. Mas depois pode passar até um mês... Mas você pode esquecer... Mas passar um mês e você se esqueceu daquilo. E você diz: ah, mas eu falei tal coisa, tal dia assim... Ele vai e conta a hora, o minuto certinho que você falou... Ele não consegue esquecer.

\section{P: Na... É... Em relação a... Ao atendimento aqui na escola. Ele tem o atendimento dentro... Na classe comum e tem... Tem... É... Suplementações em outro horário aqui com o professor...}


R1: Tem sim.

\section{P: Com o professor Batista?}

R1: Com professor Batista ele estava tendo sim aula normal. Assim... Diferenciada né?

\section{P: Como é? Ele estuda de manhã? À tarde? Como é?}

R1: É. Ele estava estudando de manhã e à tarde. Só...

\section{P: De manhã estuda na classe comum?}

R1: Na classe comum e à tarde...

\section{P: No terceiro ano?}

R1: Isso. E à tarde ele estava estudando com o professor Batista. Só que como eu estava tendo uma dificuldade aí de locomoção... Da onde eu estava morando para ele vir para cá... E estava tendo...

\section{P: É longe?}

R1: Eu estava morando lá para Pedra Branca. Aí fica bem distante. É para as bandas do Vai Quem Quer. Fica bem longe mesmo daqui. Então ficava muito cansativo para ele estar vindo de manhã e de tarde. Né? Aí foi que eu vim e conversei com o professor... Ele disse: olha é o seguinte: a gente podemos fazer assim também... Ele pode vir só no horário da... Da tarde. Ele fica um período com o professor. Com a aula... Estuda a aula normal e o outro período antes de ele sair ele pode ficar comigo. Só que não estava acontecendo isso. Né? Foi um dos pontos que eu cheguei e conversei como professor... Se daria dele voltar à aula normal... De manhã na classe normal. Né? Com o professor ali e à tarde voltasse com ele. Porque fez muita diferença essa aula para ele. Muita diferença. Porque ele não estava tendo mais aula. Aí com ele estava diferenciando muito as atividades dele... E aí estava complicando também por esse lado aí... 


\section{P: E como é que está agora atualmente?}

R1: Agora atualmente ele... Eu estava até comentando com professor... Ele está muito preocupado. Ele quer porque quer vir para o colégio. Porque pra ele é uma diversão. Para ele era estar no colégio. Por mais que ele não fizesse nada assim... No turno da manhã...

R2: Você quer um café?

R3: Não quero não...

R2: Vai querer?

\section{P: Sim.}

R1: Mas ele queria estar no colégio. Né?

\section{P: Certo.}

R1: Então agora para ele está difícil por essa maneira... Apesar desses dias que está tendo... Não está tendo aula...

R2: Aceita café senhora?

R1: Aceito sim.

\section{P: Certo.}

R1: E aí ele está muito assim... Eu sinto assim que ele está um pouquinho assim... Triste. Né? Por que... Obrigada. Ele vê o outro bondinho aqui do colégio passar... Né? E não vê o bondinho daqui do colégio passar... E ele fica perguntando porquê que não está tendo aula...

\section{P: Ele só tem atividade em casa com as professoras?}

R1: Oi? 
P: Ele está só pegando as atividades aqui?

R1: Nem as atividades ele não pegou ainda. Porque eu vim saber agora esses dias que os professores... Os professores estavam liberando as atividades para fazer em casa. Né? Aí foi que eu vim aí com professor dele... Aí estava conversando e diz ainda que as atividades que são para eles não tinham chego ainda. Ia chegar talvez amanhã... Essas atividades. Aí todo esse tempo... Todos esses dias, esses meses, eles estão, se bem dizer, sem fazer nada.

P: Mas esse ano ele chegou a voltar para... Para classe comum?

R1: Voltou.

P: Aí ficou fazendo a classe comum e faz...

R1: Isso.

$P$ : E vindo à tarde para...

R1: Com professor... Com a aula... É... Especializada.

P: E assim... Com essa atividade você acha que houve uma evolução do seu filho? O quê que você entendeu desses... Dos sete anos que ele veio para cá aos 12 anos... Se você entende que essa política da... De inclusão. Deu alguma autonomia? Algum avanço você notou no seu filho?

$\mathrm{R} 1: \mathrm{Na}$ área da aula especializada?

P: É. Na... Exatamente. Se você notou que isso... O fato de estar frequentando a escola trouxe alguns benefícios para ele?

R1: Trouxe. Bastante.

P: O quê que você pode assim... Exemplificar... 
R1: Olha... Em primeiro lugar o benefício assim... Em primeiro lugar... O primeiro benefício que trouxe para ele... Que ele começou assim a interagir com as outras crianças. Que ele não fazia isso. Era uma... Era até assim.. Para mim um motivo de tristeza. Para mim como mãe... De ver que quando ele chegava assim... Poderia estar assim... Duas, três crianças brincando ali... Que no momento que ele se aproximava as crianças paravam de brincar. Não queriam se interagir com ele. Chamavam ele de doido, dizia que ele estava ficando maluco... Isso e aquilo... Então começavam a... A criticar ele. Então ele sempre ficava sozinho. Então depois que ele entrou aqui para o colégio, que ele começou a estudar... Como eu disse: que logo no começo teve essa rejeição aqui... Começaram a malinar com ele e tudo. Então foi um pouquinho difícil dele se adaptar. Então... Mas através de muita insistência, através de... De conversar e tudo... E com a diretora e com os professores... E pedir para eles terem mais cuidado com ele... Porque mesmo nesse tempo quando ele entrou não tinha aula especializada para ele.

\section{P: Sim.}

R1: Então depois... É... O quê? Já veio ter aula especializada para ele... Dos sete anos para cá... Eu acho que está com dois anos. Não sei se... Não estou bem lembrada... Se é dois ou três anos... Que faz... Que ele está tendo essa aula...

P: Mas isso não impediu que ele pudesse ter... Esse contato... Que ele pudesse ter um... Um desenvolvimento. Mesmo semo atendimento especializado?

R1: Não. Não teve. Não teve por quê? Assim... Como eu disse: eu...

P: Não. Como eu estou dizendo... Mesmo sem o atendimento... Você achou que ele avançou na escola?

R1: Sem esse atendimento da aula especializada?

P: É... É.

R1: Não avançou nada...

\section{P: Ah você veio a notar a diferença agora?}


R1: Da agora... Depois que ele veio ter realmente essa outra aula...

\section{P: Entendi.}

R1: Porque no momento que ele estava estudando mesmo só a aula comum ele não teve avanço nenhum. Eu estava mesmo até pensando de tirar ele do colégio. Cheguei a comunicar aqui com a direção e cheguei a comunicar também com a médica dele... Aí eu disse: não estou vendo resultado. Por que... Porque desde os sete anos que ele já estuda e até agora ele não tem desenvolvimento nenhum... Só para mim estar gastando com material, gastando com isso, gastando com aquilo... Então não estou vendo retribuição. Mesmo... Não é o fato de eu querer exigir dele. Querer é... Esforço dele. Assim dessa maneira... E mesmo ele reclamava muito. Chegava em casa... Às vezes ele chegava chorando. Muitas vezes ele chegou dizendo que não queria mais vir para o colégio porque o professor tinha tratado mal...

\section{P: Então o atendimento diferenciado fez a diferença?}

R1: A mudança. Mudou muito. Muito. Foi como eu disse... Que depois que ele teve essa aula especializada foi que ele veio aprender a ler. Já... Ele não sabe muito bem, mas ele começa a soletrar ele já sabe... Conhece as letras. Já conhece a numeração. Então ele veio desenvolver muito depois que ele começou a ter essa aula especializada.

\section{P: E a interação que tu falas?}

R1: Isso. Muito. Muito. Mas antes de ter essa aula ele não desenvolveu nada.

\section{P: Então há a necessidade então de permanecer esse tipo de atendimento na escola?}

R1: Tem. Eu digo... Eu estava até dizendo para o professor... Eu disse... O professor até chegou a dizer... Ele disse: ah... É... Silvânia... Chegou um tempo aí... Que houve um problema aí... Que eu não entendi muito bem... Que ele disse que achava que ia acabar essa aula especializada daqui. Que não ia ter mais professores porque não sei o quê... Tinha vindo uma ordem de lá... Né? De Belém e tudo... E estava achando estava, estava tendo um probleminha lá e ele estava achando que não ia mais adiante. Ia encerrar essa aula especializada. Eu disse: professor Batista se acontecer isso pelo amor de Deus! Como é que se 
diz? Um dos que vai ser... Que vai sentir muito, que vai ser prejudicado é o meu filho. Porque eu dou graças a Deus em primeiro lugar, em segundo lugar depois que veio haver essa aula aqui... Então se vim a acontecer isso de encerrar essa aula aqui vai ficar a mesma coisa. Porque ele veio a desenvolver depois que vocês vieram dar essa aula para eles. Não só o meu filho, mas muitas outras crianças que têm também outras especialidades, que estuda aqui com ele também... Então todas as mães também falam pela mesma boca... Que veio de melhorar muito depois que começou a ter essa aula com eles e se acabar aqui... Era... Tá doido! Vai modificar as coisas... Vai desandar muito.

\section{P: Entendi. Você queria... É... Esclarecer mais um ponto? Assim... É... Se você acha também que houve uma aceitação melhor esses últimos anos do seu filho em relação aos outros sem deficiência aqui na escola?}

R1: Da maneira dele aceitar os outros?

P: É.

R1: Olha...

\section{P: E de os outros aceitarem ele...}

R1: Houve... Houve sim... Houve muito. Depois assim que ele começou já a se habituar aqui no colégio, depois que ele começou já a se interagir bastante aqui... Hoje como eu digo assim? Aqui ele é respeitado aqui dentro. Posso dizer... Por mesmo por ele ser uma criança alegre... Né? Extrovertida... Deus me livre! As outras crianças mesmo... Das outras sala aqui mesmo... As crianças normais agora... Elas são umas crianças assim que se dá muito com ele. No dia que ele não vinha para o colégio... Deus me livre! Eu chegava às vezes aqui na hora do recreio ele estava fazendo a festa aqui com as outras crianças e as crianças gostam muito dele. E ele conhece todo mundo aqui no colégio. Seja do professor ao aluno ele conhece. E aí na rua quando a gente sai assim.. Aí os meninos veem ele: ei Geison! Tu não vai mais para o colégio? Ei Geison! Então é assim... Foi um desenvolvimento muito grande. Logo como eu disse... Logo no começo foi difícil, mas depois assim.. E é mais assim... Como eu digo assim... É mais um motivo assim de eu não chegar a tirar ele do colégio. Mas sim dar um incentivo de ele... 


\section{P: Então você acredita nessa política da educação na escola comum? Para alunos como seu filho?}

R1: Como assim?

\section{P: Você acredita que a escola comum pode fazer a diferença?}

R1: Pode sim.

\section{P: Em relação aos alunos com deficiência?}

R1: Só depende no caso assim... Só depende de você... É... Ser persistente como eu fui. Porque logo no começo se eu tivesse desistido pela maneira que eles começaram a tratar o meu filho aqui... Mesmo as crianças rejeitando ele e tudo. Se eu tivesse desistido no primeiro passo ele não iria adiante. Então... Mas aí é um motivo de mostrar que tem a possibilidade sim. Um colégio comum, normal... Ter adaptação para uma criança que tem uma especialidade como ele ou como outras crianças que possam ter outra especialidade. Só depende de você prosseguir. Você ser insistente...

\section{P: Ok. Você quer falar mais alguma coisa? Deixar uma mensagem final?}

R1: A mensagem final que eu quero falar é o seguinte: que as mães que tenham uma criança também que seja especial... Não importa qual seja a especialidade... Né? Mas... Qual é o ponto principal para essas crianças? O que eu aprendi? Em primeiro lugar é você amar muito. Tem que ter muito amor, muito carinho para dar para essas crianças que tem esse tipo de especialidade. Que às vezes tem mãe que tem uma criança especial e não sabe como lidar e trata como se fosse, às vezes, um animal... Porque eu já presenciei... Já presenciei essa cena. Então o prato principal... Como se diz assim? Para conviver com essas crianças é ter muito amor, ter muito carinho e prosseguir adiante. Não desistir. Você chegar no ambiente que seu filho tenha o direito de participar e você chegar e uma criança rejeitar ou mesmo o professor... Seja quem for rejeitar e você recuar é pior. Você... Se você... O seu filho tem direito naquilo você tem que correr atrás. Não tem que desistir. Por que... Como assim? Como você normal você tem o direito... Principalmente uma criança que ela é especial. Ela tem um valor. É uma 
pedra preciosa. Então você tem que saber lidar. Você tem que saber lidar com a criança. Você tem que saber como conviver com aquela criança. Porque apesar de ela ser especial você... Às vezes você se torna muito mais especial do que ela. Por quê? Porque você aprendeu maneiras diferentes que você não sabia, que você nem mesmo conhecia... Então o que eu tenho para deixar para outras pessoas é o seguinte: que quem tem crianças que tem uma especialidade que cuide muito bem e que corra atrás do objetivo daquela criança. Porque se eu não tivesse corrido atrás dos objetivos do meu filho hoje em dia talvez ele não teria direito em nada. Consegui um benefício para o meu filho. Então muitas outras coisas que chegam a me dizer... Mesmo... Eu tenho conhecimento com outras pessoas assim... Mesmo outros órgãos... Chego atrás e a pessoa diz: olha seu filho tem direito. Assim, assim... Eu não sou de ficar parada. Eu vou atrás. É direito dele? Eu vou atrás. Já cheguei a pegar porta na cara? Já. Ah porque seu filho não tem direito... Não. Você diz que ele não tem direito, mas eu vou mais adiante porque eu sei que ele tem. Então o que eu tenho para deixar é isso. Que as pessoas corram atrás... Lute... Que a pessoa vai vencer.

P: Tá certo. Muito obrigado então pela sua colaboração aqui. Essa sua pesquisa... Essa nossa pesquisa vai ser feita exatamente nesse sentido. $E$ qualquer informação a mais a gente lhe procura e também qualquer divulgação será feita somente com a sua autorização. Certo?

R1: Tá bom. Muito obrigado.

TEMPO TOTAL $=30 \mathrm{~min} 30 \mathrm{seg}$ 


\section{ENTREVISTA}

Data: 04.02.2016

Local: Escola Estadual Marta da Conceição - Cotijuba - Distrito de Icoaraci - Belém / PA

Entrevistado: Silvânia Gomes da Silva

\begin{tabular}{l|l}
\hline SÍMBOLOS & LEGENDA \\
\hline $\mathbf{P}$ & Pergunta ou fala do entrevistador \\
\hline $\mathrm{R}$ & Resposta ou fala do entrevistado \\
\hline Itálico & Compreensão duvidosa \\
\hline (0min 0seg) & Trecho não compreensível \\
\hline$\ldots$ & Pausa na fala \\
\hline
\end{tabular}

\section{P: Tá... Comece com o seu nome...}

R: O meu nome é Silvânia Gomes da Silva. Né? Eu sou a mãe do Geison. Já... Que estuda aqui já há muito tempo. Desde a idade dele de sete anos ele estuda aqui. Né? Nessa escola... Quando eu vim morar pra cá. Ele estuda aqui. Então o Geison ele passou três anos estudando aqui. Só que ele não tinha desenvolvimento nenhum.. Né? Porque pela especialidade dele ele enfrentou muitos problemas para estudar aqui.

\section{P: Ele tem uma deficiência intelectual?}

R: É. Exatamente. Então ele é assim uma criança que ele tem uma dificuldade muito grande. Uma aprendizagem né? $\mathrm{O}$ aprendizado dele então... Ele é assim... Ele é uma criança inteligente, mas ao mesmo tempo é uma criança muito lenta na aprendizagem dele. Então ele veio desenvolver... Chegar a desenvolver mais... Assim o... A inteligência dele. Depois que chegou a acontecer essa aula especializada que colocaram aqui. Depois já de quatro anos que ele estava estudando aqui. Aí foi que os professores entraram em reunião... Aí achava que não estava tendo a... O desenvolvimento para essas crianças especiais que estudavam aqui e estavam estudando normal. Porque umas... As... As crianças sem problema nenhum estavam desenvolvendo e essas crianças elas estavam ficando para trás. 


\section{P: Entendi...}

R: Então chegou um dia de eu chegar aqui com o professor e falar com ele que não estava tendo possibilidade de eu mandar o meu filho mais... Vir para cá para o colégio... Por quê? Ele passava... Ele vinha das sete da manhã, saía meio dia... Chegava em casa ele não fazia duas palavras no caderno. E o... Aí eu cheguei a vim fazer reclamação com professor ainda... E ele disse: só que eu não posso ficar empatado com o seu filho...

\section{P: Foi o professor?}

R: Foi. Que falou: eu não posso ficar empatado com seu filho porque eu tenho uma classe grande de aluno.

\section{P: E esse professor era de que série?}

R: Oi? Ele estava na segunda série.

\section{P: Quem era o professor?}

R: O professor dele era... Professora Rosana. Rosana.

P: É.

R: Aí foi que ela falou isso. Né? E disse: eu não posso ficar empatado com ele. Por quê? Eu tenho uma... Uma sala grande de aluno. Uma classe grande... Então eu não posso ficar. Aí foi que eu disse: se for para ser dessa maneira dele vir só para cá passar o dia... Então para mim não vai adiantar. Porque não está tendo desenvolvimento com o meu filho. Aí foi que eu conversei, foi que eu conheci o professor Batista também... Aí conversei com ele e foi que ele disse que estava saindo esse projeto dessa aula especializada para as crianças com deficiência. Né? Aí...

P: Isso é recente... Porque o professor Batista está há pouco mais de um ano e meio...

R: Foi. Foi pouco tempo. Agora que essa aula especializada veio a acontecer... Já... Eu acho que vai fazer... Já faz quase dois anos porque ele começou no tempo da professora Dora... 


\section{P: Sim}

R: Todo o desenvolvimento começou no tempo da professora Dora. Aí participava de atividades... Muitas atividades eu participei com ele também. E tudo... Aí já depois da professora Dora foi que ele passou para o poder do professor Batista. E foi daí que já começou o desenvolvimento dele... Nas aulas dele, no... No... Até mesmo no aprendizagem dele... Ele veio a começar a melhorar por aí...

P: Ele está há quantos anos na escola?

R: Ele... Ele está com... Vai fazer... Seis anos...

\section{P: Na escola?}

R: Na escola já...

P: Então desses seis anos só dois anos que ele recebeu atendimento especializado?

R: Dois anos.

P: E nesses quatro anos primeiros? A professora Dora não estava aqui mais?

R: Não estava... Porque assim... Porque quando ele estava... Que eu coloquei ele... Eu não sabia né? Então daí desses quatro anos para trás eu não... Como é que se diz? Não estava tendo essa aula especializada...

P: É...

R: Não estava tendo. Então...

P: Ele tem um... O quê que essa aula faz com ele? Ele tem... Essa aula ele tem em um horário diferente do da escola? 
R: Isso. Que são... É um horário especializado para ele né? Porque como ele estudava das sete às onze e meia... Aí depois que saiu essa aula... Que o... A professora colocou... Teve essa... Essa aula especializada... Então tinha um horário só para ele. Ele estudava de manhã. Normal né? E quando era à tarde era o horário dele com a professora especializada. Que era das duas às três da tarde. Então era um horário que era só... É... É... Realmente especificado para eles. Atenção só para ele. Aí foi quando ele começou a desenvolver... Nessa aula.

\section{P: O que é que ele desenvolveu que você diz?}

R: Ele desenvolveu muito. Assim.. No conhecimento. Que ele não conhecia o alfabeto. Ele começou a conhecer...

\section{P: Ele já escreve?}

R: Ele escreve, mas ele tem assim... Essa dificuldade na coordenação motora dele. Ele tem essa dificuldade. Mas ele...

\section{P: Ele já reconhece as letras que ele não reconhecia?}

R: Reconhece. Não. Ele não reconhecia. Ele hoje ele reconhece as letras. Ele já sabe já a matemática já... Então depois dessa aula eu achei que ele desenvolveu bastante, mas antes disso eu estava muito desanimada. Cheguei a conversar mesmo aqui com os professores. Cheguei ainda a vir aqui com o diretor... Com a outra diretora que era... Que era até no tempo do professor Donza também. Conversei com o professor Donza...

\section{P: E o quê que eles falaram?}

R: Aí... Ele disse que eles estavam correndo atrás desse... Justamente dessa aula. Porque muitos alunos que estudam aqui... Também especial... Estavam tendo esse... Esse problema. Dessa dificuldade de aprendizagem. E é uma coisa que os professores mesmo não poderiam ficar empatados porque eles não têm como ele falou... Assim... Que eles não têm essa capacidade... Essa habilidade assim de lidar com essas crianças especial. Porque eles são os professores para lidar com as outras crianças né? Normal... Aluno normal. E eles não têm 
assim esse... Ensino para... Tinha que ter um professor especial realmente para poder ensinar e dar essa aula para essas crianças... Essa atenção que eles mereciam...

P: Sim, mas o professor... É... O professor especial está aqui, mas ele continua lidando com os professores normais... Da classe regular...

R: Isso. Porque ele...

P: Como é que está sendo esse contato dele? Mudou também alguma coisa ou... Em relação a esse período que ele passa... Da manhã...

R: Olhe... Para mim assim... Não está tendo muito lucro. Não está tendo muito lucro por quê?

P: Você já chegou a vim aqui e ver como é que ele é na classe?

R: Já. Já... Olha já vim já... Várias vezes. Uma vez dessas...

\section{P: E como é que ele fica dentro da sala?}

R: Ele simplesmente... Ele fica sentado dentro da sala. Às vezes ele sai no horário do recreio né? Que ele... Que tem o horário do recreio e ele vem e sai para merendar. Aí depois do recreio ele fica. Só que assim... No caso do professor parar... Passar a leitura... Passar... Como é que se diz? As atividades no quadro e ele não consegue acompanhar. Ele não tem aquela habilidade de escrever como os outros alunos. Aí então o tempo passa, o professor apaga e passa outro trabalho e ele fica só naquilo... Aí uma vez eu cheguei e vim conversar aqui com o professor... Que agora é o professor dele... Que é o professor... Eu me esqueci o nome dele... Ele está até aí na sala de aula... Aí o... Walter.

P: É...

R: Aí eu soube de umas coisas aí... Que ele estava saindo um pouquinho ignorante com ele... Isso e aquilo... E eu peguei e vim... Vim fazer... Como é que se diz? Vim fazer o meu papel de mãe. Né? Porque pelo problema dele... Eu vim saber o que estava acontecendo. Aí foi que o professor disse: não, realmente ele é uma criança muito vagarosa mesmo. Ele é muito passivo 
assim... Só que eu não posso ficar assim... Perder muito tempo com ele porque tem os outros alunos que já tem uma habilidade mais rápida. Né? Porque são os alunos mesmo que não tem especialidade nenhuma assim... No caso, não tem problema. Então eu não posso passar muito tempo só com um dever... Só esperando ele. Então ele não tem desenvolvimento nessa área. Na aula normal... Assim... Comum... De manhã...

\section{P: Ele só tem aula com professor Walter na escola? \\ R: É.}

\section{P: Então tu achas que falta paciência para o professor?}

R: Eu... Tipo assim... Não é bem paciência. E sim... Porque assim... Pelo problema dele... Assim que ele tem... Eu acho que poderia assim.. Ter mais assim... Um pouco sim de paciência. Porque pela... A... Como é que se diz? O problema que eu estou the falando que ele tem... Não é o fato da ignorância... Ou então assim... O fato assim... De dizer que ele corre assim... Por quê... Como é que se diz? Acho que se tivesse um pouco mais de atenção por essa área aí... Eu acho que ele desenvolvia mais um pouco.

\section{P: A... Nesse caso a senhora acha que não tem assim um planejamento? Um... Para o ensino na sala regular do... Do Geison...}

R: Eu... Eu penso por esse lado. Eu penso por esse lado. Porque eu acho que se havesse mais assim... Um pouco mais de atenção, um pouco mais de desenvolvimento... Eu acho que ele poderia acompanhar também. Tudo vai da paciência da pessoa também.

\section{P: Entendi. E em relação aos outros alunos? Você recebeu nesse período alguma reclamação? Algum... Uma situação assim... De constrangimento do seu filho aqui na escola... A aceitação dele...}

R: Olha... Logo no começo eu... Como é que se diz? Logo no começo eu recebi bastante reclamação sim. Mesmo pelo lado do meu outro filho que estuda também o mesmo horário que ele. Né? Então ele me falava que na hora do recreio os outros meninos ficavam mexendo com ele, ficavam chamando ele de doido... Então ele é uma criança assim... Ele tem 12 anos, mas ele é uma criança que tudo que você mandar ele fazer, ele faz. Para ele não tem. Não tem 
malícia nenhuma. Não tem assim... Não tem perigo. Não tem nada disso. Ele não vê maldade em nada. Se você mandar ele fazer qualquer coisa, seja o que for, por mais que aquilo não seja certo, ele faz. Então os meninos faziam dele aqui de gato e sapato. Aqui no colégio... Aí quando foi um dia ele foi no bondinho. Que ele ia e voltava no bondinho... Né? Aí quando foi um dia ele chegou lá em casa... Ele tem um problema na pele que qualquer coisinha que trisca na pele dele... Ele tem uma pele muito sensível. Então tudo que pega assim nele... Assim... Fica logo encalombado, fica logo vermelho. Aí quando foi um dia ele chegou lá em casa com o rosto todo vermelho. Todo encalombado o rosto dele. Aí eu perguntei o que foi que tinha acontecido... Aí me falaram que tinha sido um dos meninos aqui do colégio que tinham pegado pimenta e tinham passado no rosto dele. Na brincadeira do bondinho... Aí eu peguei e vim fazer a reclamação aqui para o diretor. Eu disse: não tem condições. Se eu boto o meu filho no colégio e se no exato momento que ele vai num transporte e tem a pessoa para reparar ele no transporte que eles vão... Não é para estar acontecendo um tipo de situação dessa. Vim, fiz a reclamação aí... Parece que chamaram o menino a atenção. Aí melhorou um pouco. Aí eu tirei ele do transporte. Mandei ele vir de bicicleta para o colégio. Como ele sabe andar de bicicleta eu mandei ele vim para o colégio de bicicleta. Aí foi que melhorou... Aí depois o rapaz que estuda aqui também me chamou atenção e disse: olha, eu acho melhor que você repare mais um pouco seu filho. Vá acompanhar as aulas dele... Vá reparar a situação que ele está sendo tratado no colégio pelos outros alunos. Porque está tendo já quase um tipo de bullying no colégio com ele. Porque assim... Eu mando ele no colégio.... Para o colégio de manhã... Com o meu outro filho. Eu fico em casa. Tenho o meu outro filho. São três filhos que eu tenho com ele. Então eu fico em casa fazendo as minhas atividades. Eu não sei o quê que está acontecendo aqui. Duas vezes... Das vezes... Duas vezes por semana eu venho saber com o professor... Eu venho às vezes aqui... Eu venho na frente fazer umas compras e eu venho aqui... Professor como é que está? Está tudo bem... Só que eu às vezes eu não sei o que está acontecendo. Né? E às vezes... Muitas vezes pode estar acontecendo alguma coisa e a pessoa não queira falar. E ele é uma criança que ele não fala. Fica na dele...

\section{P: Ele está aí na... Na...}

R: Não. Ele vem agora no horário da tarde. Ele está... Passaram ele para o horário da tarde. Ele está vindo agora à tarde.

\section{P: Ele vem que horas agora?}


R: Ele vem a partir de uma hora, uma e meia... Por aí...

\section{P: Certo... Ele fala?}

R: Fala... Ele conversa normal. Se você sentar para conversar com ele, ele conversa normal... Ele... Ele é uma criança bem inteligente. Por esse olhar... Ele é uma criança curiosa, ele é uma criança assim... Bem... Meio em uma expectativa... Bem animada mesmo. Assim desse lado...

\section{P: E a senhora autoriza a gente a ouvi-lo?}

R: Não tem problema.

P: É?

R: Pode conversar com ele...

P: Certo. É... E até para a gente poder também ouvir né? O destinatário do serviço. Né? A gente está ouvindo você, ouvindo o professor... Eu acho que seria interessante ouvilo...

R: É...

P: E o que... O que ele diz assim? Qual é... As expectativas do Geison assim... A senhora como mãe conhece melhor do que ninguém... O quê que a senhora nota? Assim... As expectativas de vida dele? Da escola...

R: Olha... Ele é louco pelo colégio. Assim.. Para negócio de estudar, apesar assim dele... Assim... Não se desenvolver muito... Às vezes assim... Mas é o sonho dele. No dia que eu digo assim que não vai ter aula... Esses tempos ele passou assim... Esses tempos que o colégio estava em reforma. Ele... Eu senti que ele ficou muito baqueado por isso. São duas coisas que é a paixão da vida dele: é o estudar e para ir para a igreja. Nós somos evangélicos né?

\section{P: Certo.}


R: Então é duas coisas que ele assim... Que parece assim que brilha no rosto dele. Deus me livre! Olha... De... Foi de ontem para cá... Toda hora... Ele assim... Ele tem uma ansiedade às vezes... Assim... Que ele não consegue nem dormir de noite. Aí toda hora ele fica perguntando. Ele está lá em casa eufórico para vir para o colégio. Então para ele assim... Por mais que ele não venha assim... E não tenha esse desenvolvimento assim... Mas ele estando no colégio para ele é tudo que ele quer.

P: É... Quais são? Além das dificuldades de aprendizado ele tem assim... Autonomia para ir no banheiro, para se locomover...

R: Não. Não. Normal. Por esse lado...

\section{P: Ele faz a higiene normal?}

R: Faz. Normal... Graças a Deus! Por esse lado aí não tem problema nenhum.

\section{P: Se relaciona bem com os irmãos?}

R: Muito bem.

\section{P: Faz algumas tarefas em casa? Ele sai?}

$\mathrm{R}$ : Eu boto sim para ele fazer.

\section{P: E ele atende a comandos assim?}

R: Atende. Tem horas assim que ele quer ficar um pouco rebelde... Eu... Faz... Eu grito mais alto. Porque assim... Pelo...

\section{P: Ele... Ele dorme em rede ou em cama?}

R: Ele dorme em rede.

\section{P: Aí... Desata a rede dele?}


R: É... Assim... Porque no quarto que eles dormem... São um quarto para os três. Né? Aí um dorme na cama e dois na rede. Aí quando é de manhã eu mando, às vezes, ele levantar a rede dele... Aí quando não é eu mando ele tirar da escápula e coisar... Ele faz assim as atividades... Só que ele é um pouco preguiçoso. Posso te falar dessa maneira. Ele tem um pouquinho de preguiça assim.. De fazer as coisas... Ele vai, mas é resmungando. Mas tirando disso, normal... Graças a Deus.

\section{P: E as atividades da escola? Nesse período teve várias atividades para fazer em casa...}

R: Ele fez. Fez atividade. Eu vim aqui, peguei os trabalhos dele. Ele fez os trabalhos dele tudinho. Graças a Deus...

\section{P: Ele precisa de ajuda? A senhora ajuda ele?}

R: Eu ajudo. Por esse lado eu ajudo. Porque assim... Ele não tem assim aquele conhecimento. Não tem aquele desenvolvimento. Então assim... Ele tem aquela dificuldade. Então eu tenho que estar em cima dele, incentivando ele... É... Mostrando para ele como é que tem que fazer. Às vezes eu termino de explicar assim.. É um dever que tem pra fazer. Eu termino de explicar como é pra fazer ele fica ali olhando para aquele trabalho. Aí ele fica, fica... Aí ele fica com o lápis na mão e ele não consegue. Aí eu tenho que ir explicar de novo como é que é para ele fazer. Parece assim que ele entende, mas ao mesmo tempo parece assim que aquilo foge da mente dele. Aí tem que estar em cima. É... Eu acho que é por isso que o... Um meio assim de dificuldade para ele, às vezes, acompanhar o trabalho dentro da classe de aula. E é por isso que ele fica atrasado.

\section{P: Aí... É... A senhora verifica, por exemplo, quando ele faz uma atividade? Por exemplo, de escrever ou de pintar... Quais dificuldades que ele tem? É...}

R: A dificuldade dele de escrever é que... Eu não sei... Para the falar a verdade eu não sei nem como assim explicar... Porque na maneira dele escrever... Ele às vezes escreve uma letra e às vezes ele bota muita dificuldade de escrever a outra, por mais que ele conheça a letra.

\section{P: Ele não consegue fazer uma frase toda?}


R: Ele não consegue...

\section{P: E nem uma palavra?}

R: É... Às vezes ele faz o nome dele muito, muito, muito, muito mal mesmo. Muito mal...

\section{P: Ele não consegue ler ainda?}

R: Ele já sabe ler já...

P: Ele já sabe ler...

R: Já. A gente mostra... Aí pede para ele soletrar... Aí ele vai. Ele já sabe soletrar já...

P: E... Aí... Ele lê uma frase?

R: Isso.

\section{P: Ele não sabe ainda escrever aquela frase?}

R: Aquela frase. Aí tem que...

\section{P: Só se for ditado?}

R: Isso. Aí tem que estar dizendo para ele qual é as letras... Olha: tem que ser a letra assim, assim, assim... Para ele ir botando as letras...

\section{P: E números?}

R: Os números ele já sabe já... Fazer já... Ele já sabe contar, já sabe fazer já... Já para o lado...

\section{P: Ele já sabe contar?}


R: Sabe. Já para o lado da Matemática ele já... Eu já vi que ele já tem mais um desenvolvimento para o lado da Matemática do que do Português.

\section{P: Se mandar ele comprar alguma coisa ele já sabe dar o troco?}

R: Sabe. Ele sabe dar o dinheiro. Só que assim...

(Risos)

R: Ele... No caso se eu mandar ele comprar alguma coisa... Que eu sempre boto ele assim para comprar... De manhã é ele que vai comprar o pão. Uma coisa assim pequena... No caso uma compra pequena... Um açúcar, um arroz... Assim... Perto lá... Eu já dou já o dinheiro certinho para ele. Porque se eu... No caso eu mandar ele comprar pão, se eu der cinco Reais para ele comprar pão... Se eu mandar ele comprar um Real ele traz aqueles cinco Reais de pão. Tudinho... Eu digo... Aí eu chego em casa... Cadê? Eu te mandei tu comprar um Real. Cadê o troco? Ele diz: ah, não tinha troco. Ele compra. Se eu der dez reais é dez Reais que ele compra.

\section{P: E... E essa reforma da escola agora? Quais são as suas expectativas para essa nova fase da escola?}

R: Professor... Assim... No momento ainda eu... Eu digo assim que eu estou por fora. Porque pelo tempo que faz assim né? Dessa reforma desse colégio... Muito tempo mesmo os professores já vinham falando que ia haver que estava... Que realmente estava precisando dessa reforma mesmo nesse colégio aqui. A situação estava um pouco precária mesmo. No momento ainda teve... Já teve uma reunião aqui que foi convocado os pais. Eu não pude comparecer por motivo de doença. Que eu estava doente e eu não pude comparecer nessa reunião. Que eu quero até conversar com o professor dele. Que é o professor Valter. Eu ainda não tive oportunidade de conversar com ele ainda para...

\section{P: Ele está aí... O professor...}

R: Para saber sobre o que foi que aconteceu nessa reunião... Que era justamente sobre o retorno das aulas e sobre a reforma desse colégio né? Que eles estavam querendo colocar em 
pauta aí... Então no momento eu não posso... Assim... Especificar algo assim... Porque eu estou por fora desse assunto. Mas pelo estado que eu estou vendo a situação do colégio... Também até mesmo do meio do transporte aí... Que chegou um transporte novo né? Para chegar a locomover as crianças... Eu estou muito feliz. Se prosseguir assim... É... Um... Posso dizer assim... Um novo colégio e não só pesar pelo seu novo colégio que foi reformado... $\mathrm{E}$ as aulas continuar numa boa vai ser maravilhoso. Agora não adianta você... Numa localidade você morar... Ter um colégio novo, um colégio bonito e em compensação às aulas não... Não chegar... Como é que se diz? Competir. Não é verdade?

\section{P: Sim...}

R: Então o que importa é que seja uma nova fase. Um novo trabalho e que os professores venham a fazer realmente o trabalho deles certo. É isso que me deixa feliz.

\section{P: Tá certo. Muito obrigado então pela sua... A senhora queria falar alguma coisa sobre as expectativas do... De... Do desenvolvimento do seu filho... O quê que a senhora imagina que a escola poderia trazer? $\mathrm{E}$ em que condições a senhora acha que a escola poderia dar mais para o seufilho?}

R: Olhe... Assim... No momento o que eu posso dizer assim... Até no exato momento... Até agora eu estou feliz pelo desenvolvimento do meu outro filho também. Que está aqui também... Graças a Deus que ele está estudando. Que ele também... Pelo tempo que ele está estudando aqui. Estou feliz pelo desenvolvimento dele. Por ele também... Como eu falei: depois que veio acontecer essa aula para eles aí... Então ele desenvolvimento... Chegou a desenvolver bastante. Então a minha expectativa é o seguinte: que venha a melhorar cada vez mais né? De agora em diante... Que venha cada vez mais. Porque eu digo assim: eu sou um tipo de mãe bem.. Assim bem... Bem passiva e ao mesmo tempo preocupada assim... Porque se eu ver alguma coisa de errado principalmente para o lado dele... Se eu ver alguma coisa de errado eu venho em cima. Eu venho procurar os direitos. Porque assim como ele... Como é que se diz? Eu como mãe eu tenho direito. Ele tem muito mais porque ele é uma criança especial e ele tem os direitos dele. Então eu sou um tipo de pessoa que eu venho em cima. Se está tudo certo, tá tudo OK. Tá de parabéns. Agora se houver alguma coisa irregular eu venho em cima. Então até no exato momento eu creio que está tudo bem. Porque como eu cheguei a falar como professor... O que estava me preocupando era isso. Porque não estava adiantando 
ele vir para o colégio e não está tendo desenvolvimento nenhum. Mas passou para este lado aí... Da aula aí... Que eu vou até conversar também com professor Batista para saber o horário que vai ser a hora da aula dele. Né? Porque no momento ele está tendo aula só... Aula normal...

\section{P: À tarde?}

R: À tarde. Só está tendo a aula normal. Não está tendo a aula ainda... Especializada ainda... Porque mesmo começou essa semana... Né? Eu não sei ainda como é ainda que vai ficar ainda o horário das atividades... Aí eu tenho ainda que sentar com professor dele e saber como é... Mas por enquanto eu posso dizer que está de parabéns. Mas qualquer irregularidade que acontecer eu venho em cima.

P: E só para finalizar... E ele recebe algum tipo de atendimento na área da saúde? Que ele necessita...

R: Por aqui mesmo não... Ele recebe... Ele tem um acompanhamento dele. Que eu faço o acompanhamento dele para Belém...

P: Mas assim... É de quê?

R: Ele faz tratamento lá pelo CAPES da casa da criança. Né?

\section{P: Ele toma algum remédio controlado?}

$\mathrm{R}$ : Toma. Ele toma remédio.

\section{P: Qual remédio que ele toma?}

R: Olha eu não estou lembrada o nome do remédio aqui no momento...

\section{P: Mas ele está tomando? Ou...}

R: Ele toma. Toma à noite. 


\section{P: Mas ele continuou tomando? Regularmente?}

R: É... Toma. É... Todo... Ele toma o da noite para dormir. Que é calmante né? E toma um durante o dia também...

P: Então... Eu sei... O remédio... É...

R: São dois tipos de medicamento, na verdade, que ele toma...

P: Certo...

R: Que é um.. Das... Um que ele toma no horário das oito da manhã e o outro que é das sete da noite.

P: E como é que a senhora... A senhora recebe esses... Esses medicamentos do CAPES?

R: Recebo. Recebo esses medicamentos pelo CAPES.

\section{P: Não têm faltado? Esses medicamentos...}

R: Não. Não. Não... Justamente ele tem uma consulta agora dia 16 agora, desse mês agora. E quando chega acontecer de eu falhar assim as consultas dele por motivo de... Financeiro. Eu posso dizer dessa maneira... Porque aqui nós tudo... Nós podemos... Tem que se locomover através da embarcação e tudo... Né? Aí eu ligo para lá para remarcar a consulta dele. Eu não sou de falhar as consultas dele...

\section{P: E os remédios são fornecidos gratuitamente pelo CAPES?}

R: É... Pelo hospital... É...

P: Qual é o CAPES que atende? 
R: Olha o CAPES que ele está sendo atendido agora... Eu... Eu não sei o nome da rua. Eu sei que eu desço bem ali de frente ao... O hospital Porto Dinha e entra naquela rua direto... Ali... Já fica ali para trás ali... Eu não estou lembrada o nome da rua.

\section{P: Tá certo... Entendi.}

R: Que foi mudado. Que era lá para banda de Nazaré o CAPES. Aí mudou para a banda daí agora... Aí na Augusta... (22min).

\section{P: Sem esse medicamento ele não dorme? Fica agitado?}

R: Ele fica agitado. Fica muito agitado. Ele passa a noite acordado. Ele não consegue dormir. Aí então para ele dormir... Ele ficar bem tranquilo assim... Ele toma esse medicamento durante a noite.

P: Isso... Se ele não tomar o remédio... Isso causa problema inclusive para ele para vir para escola?

R: Exatamente. Porque aí no caso ele vem... E ele fica muito... Muito hiperativo. Fica muito assim... Eufórico assim.. E aí ele fica muito ativo. Aí então quando ele toma o medicamento ele fica bem calmo.

\section{P: Sim. E aí ele tem condições de vir para escola?}

R: Ele vem para o colégio normal. Só que eu estava dando ele em um horário que ele estava tomando um aí... Que até a médica trocou... Mudou o... Esse medicamento dele. E ele então... Ele vinha para o colégio... Ele era muito forte. Ele estava ficando muito sonolento...

\section{P: Entendi.}

R: Então ele vinha para o colégio e ele passava a maioria do tempo dormindo... Aí eu peguei e fui lá com a doutora... Aí expliquei para ela. Porque estava também já prejudicando ele no colégio. Né? Aí ela foi e trocou. No caso agora ele toma só meia banda da medicação que ele toma... 


\section{P: E aí ele consegue vir?}

R: Aí ele consegue vir normal. Graças a Deus.

P: E... Deixa eu te dizer... Só para... Nesse caso ele... É... Ele falta aula?

R: Muito difícil.

P: É?

R: Muito difícil. Quando... Mesmo assim para ele faltar à aula só no caso quando eu vou levar ele no médico ou então mesmo no caso se ele adoecer. Porque assim... Quando ele está assim que ele pega alguma gripe, alguma coisa assim... Eu não gosto de deixar ele vir para o colégio. Assim... Mesmo... Eu já conversei com os professores. Ele é uma criança assim... Muito melindrosa por esse lado de doença. Deus me livre. Aí então quando ele vem assim eu prefiro tratar ele em casa quando ele está melhor já mandar ele vir para o colégio. Mas todas as faltas dele eu chego vim... É explicar aqui o motivo porque ele não veio.

P: Tá certo então dona Silvânia. Muito obrigado. Eu vou pegar só uma autorização por escrito da senhora para que a gente possa é... É... Fazer lá as informações do Geison. E eu lhe dou o retorno sobre essas medidas que forem necessárias para garantir o atendimento educacional especializado dele.

R: Tá OK.

P: Tá? Obrigado!

TEMPO TOTAL $=24 \mathrm{~min} 42 \mathrm{seg}$ 


\section{ENTREVISTA}

Data: 04.02.2016

Local: Praça de Cotijuba - Distrito de Icoaraci - Belém / PA

Entrevistado: Raimundo Nonato Torres, Pai do aluno Israel

\begin{tabular}{l|l}
\hline SÍMBOLOS & LEGENDA \\
\hline $\mathbf{P}$ & Pergunta ou fala do entrevistador \\
\hline $\mathrm{R}$ & Resposta ou fala do entrevistado \\
\hline Itálico & Compreensão duvidosa \\
\hline (0min 0seg) & Trecho não compreensível \\
\hline$\ldots$ & Pausa na fala \\
\hline
\end{tabular}

P: É... Eu falo novamente com o pai do Israel... O Francisco não é?

R1: Raimundo.

P: Raimundo...

R1: Nonato

P: Raimundo Nonato. Então Raimundo... É... Ele voltou agora nesse primeiro... Nessa primeira semana de aula mais agitado?

R1: Mais agitado.

P: Tu achas que a professora é... Não... Não... Você acha que falta...

R1: É... Falta... Eu acho que falta capacitação para ela. Porque ela é daqui né? E ela não tem... Assim a... Eu acho que... É... Um aprendizado para lidar com ele. Lá na escola Bosque a outra tinha, mas ela... Ela não tem. A Sandra não tem. Então teria que ter duas professoras para ele, uma que ensine mesmo... O normal às crianças né? $\mathrm{E}$ a outra que... É... É... É... Lide bem com isso aí... Quando ele está com essa revolta dele lá dentro da sala... 
P: E... Ele não para dentro da sala? Ele sai?

R1: Não. Não. Não... Ele sai...

\section{P: Ele vai para outra sala?}

R1: É... Ele quer bater na professora... Ele... Ele fica... Tirando um comportamento que ele não tira em casa. Né?

R2: Tem coisas que ele não faz em casa e ele faz no colégio...

R1: Aí já faz... Já começa a fazer já...

R2: É difícil por que...

P: Senta aqui oh...

R2: Às vezes as pessoas pensam que ele faz em casa, mas ele não faz em casa. De querer bater... Ontem eu cheguei na hora lá. Estava uma luta para trazer ele para vir embora. Aí a professora já me pediu, pelo amor de Deus, para mim deixar ele e...

\section{P: Deixar ele aonde?}

R2: É... Lá no colégio. E ir buscar. Aí o Batista já falou ontem que ele vai reduzir o tempo dele. Só que eu acho isso errado.

P: Quer dizer... Não existe então uma... Uma flexibilização para o caso dele?

R2: Não.

P: A professora quer tratar ele como...

R2: Como um normal... 


\section{P: Sim...}

R2: Aí o quê que acontece? Quando ele está demais...

P: Aí não tem uma atenção... É isso que o...

R1: É...

R2: Raimundo...

\section{P: Que o Raimundo está falando...}

R2: Quando ele está demais, ela pega eles e leva eles para sala dos meninos... Aí já atrapalha os meninos.

P: Ah sim... Ela tira da sala dela e coloca...

R2: E vai ele... Levar ele lá para os meninos...

\section{P: Para os irmãos dele?}

R2: Aí vamos supor... Se ele entrar à uma hora... O normal dele... Normal é cinco horas né? O horário? Cinco horas... O Batista disse que quer reduzir...

\section{P: Sim.}

$\mathrm{R} 2$ : Eu não acho isso certo. Ele querer reduzir o horário dele... Tem que fazer ele se acostumar lá no colégio...

\section{P: Isso! Com os demais...}

R2: Né? Pois é... Se acostumar a saber o que é... É... O colégio o que é? Que é para aprender... Fazer o dever dele... Que ele não quer fazer... Entendeu? Aí o Batista falou para mim ontem... Aí eu disse: ah Batista, mas aí né? Ele disse: a gente vai ter que reduzir. Eu não quero que 
reduza, eu quero que ele fique o horário todinho no colégio. Acho que o Batista tem capacidade para isso.

\section{P: É... Pelo menos...}

R2: O Batista eu sei que tem. Que ele estuda, fez curso... Fez uns estudos lá... Para esse tipo de criança... Então ele sabe. É isso que eu acho ruim. Os meninos estavam até reclamando: mãe a professora manda o Dinho para lá com nós... Eu até ia falar para ela não mandar. E eu até falei para o Batista: Batista, tu e a professora, vocês tem que falar, com o Israel, firme! Não deixa ele perceber que vocês estão mimando ele. Fala firme com ele. (02min $55 \mathrm{seg})$. O Batista: ah mãe, mas não tem problema... Se os meninos chegarem me falando lá é porque eu já te dei autorização... Manda ele sentar e fala. Porque tem vez que tem que ser assim. Até comigo também... Às vezes eu tenho que ser firme com ele. Porque ele escuta mais o pai dele do que eu...

P: Quer dizer, a professora mesmo está... Está se eximindo da responsabilidade... Tira ele de lá para não...

R1: É...

R2: Pois é... Às vezes... É que ela está demais... Aí ela já não sabe se olha ele ou se olha o resto dos meninos. Aí pelo um ponto eu... Eu dou a coisa pra ela... Por causa que é só ela...

R1: Ela não é capacitada né?

R2: Aí vamos supor... Se ela for pegar para ensinar... Porque ontem eu sentei ele e comecei a ensinar umas coisas para ele que eu aprendi lá na APAE. Quer dizer, eu passei mais de uma hora só com ele. Então ela, no caso... Se ela for pegar para ensinar ele, ela larga os outros de mão... É o que não pode né? Por isso que tem que ter duas. Lá na Bosque ele tinha duas.

\section{P: Quer dizer... Não tem uma professora para auxiliá-la?}

R2: Isso! Para auxiliar ela.

\section{P: E fazendo a primeira série...}


R2: É... É isso aí!

P: Tens alguma coisa para falar mais Raimundo? Tu não estavas falando que... É... É essa dificuldade de não ter assim... Um planejamento específico para ele né?

R1: É... As dificuldades na Escola Marta da Conceição é essa aí né? Que não tem uma pessoa capacitada para ficar com ele. Antigamente tinha que era a professora Dora Estela né? Que ela é... Era professora do mudo, surdo, do... Dele e de outras pessoas... Que tinha esse tipo de coisa aí...

\section{P: Da deficiência intelectual que ele tem...}

R1: Deficiência. Isso. Aí ela era capacitada... Fez estudo, fez curso... Parece que foi... É diplomada ela né? Em tudo isso aí...

\section{P: Ela não chegou a atender ele né?}

R1: Não. Não, não... Mas ela deu a maior força no começo para a gente. Deu a maior força no começo. Agora o que está faltando na Marta é isso aí... Eu acho que um professor específico para eles. Porque não é só ele né?

\section{P: Tem outros alunos?}

R1: Tem. Tem! Tem outras pessoas... Tem outros alunos lá. Tem outros meninos lá que não tem... É... Não são assim... Um pouco normal né? Não são normal como a gente, como os outros...

R2: Tem uma outra menina lá... Tem uns três... Na sala dele tem ele e mais uma que é muda... E surda parece...

\section{P: Sim.}


R2: E... Ainda tem... Aí a mãe dela levava ela para e Icoaraci. Aí deixa ela aí na Marta também. Saiu da Bosque e foi para Marta. Ainda tem... Aí diz que quando ela começa a falar o Israel começa também... Às vezes a mexer com ela né?

\section{P: Entendi...}

R2: Aí se ela for bater no Israel... Aí já vai... E é essa dificuldade aí que tem. Tem que estar de olho neles todos. E só uma é difícil...

P: Tá ok Raimundo. Obrigado então. É... Ontem eu cheguei...

TEMPO TOTAL $=5 \mathrm{~min} 31 \mathrm{seg}$ 


\section{ENTREVISTA}

Data: 25 de agosto de 2015

Local: Escola Estadual Marta da Conceição - Anexo Urubuoca - Distrito de Icoaraci Belém / PA

Entrevistada: Professora Maria Alba Moraes dos Santos

\begin{tabular}{l|l}
\hline SÍMBOLOS & LEGENDA \\
\hline $\mathbf{P}$ & Pergunta ou fala do entre vistador \\
\hline $\mathrm{R}$ & Resposta ou fala do entrevistado \\
\hline Itálico & Compreensão duvidosa \\
\hline (0min 0seg) & Trecho não compreensível \\
\hline$\ldots$ & Pausa na fala \\
\hline
\end{tabular}

\section{P: Ok. Não se preocupe com isso...}

R: O meu nome é Maria Alba Moraes dos Santos. Eu sou professora de primeiro ao quinto ano. Eu trabalho na escola Pedra Branca pela manhã e à tarde eu trabalho no anexo Urubuoca. Estou caminhando para os vinte e três anos de Estado... (Risos). Comecei ainda quando era o quinto ano aqui... Se podia trabalhar... E hoje eu trabalho com muito seriado... Nunca trabalhei com as séries... É... Normais... Assim... Só muito seriado... Porque é ilha, tem carência e tudo mais... E quando a gente começou a trabalhar nós não tínhamos alunos com essas dificuldades que nem em outra escola. A partir do ano de 2014, quando eu comecei a trabalhar no Pedra Branca, foi que eu comecei a observar esse aluno que é o Joel. Ele tem dezessete anos... Tem uma característica bem diferenciada dos outros alunos. E ele apresenta uma série de dificuldades... De memória, é... Aprendizado... Sim... Tem outras situações que ele apresenta que não são bem características de normalidade né? E a gente começou a observar e tentou começar a conversar com os pais. E os pais infelizmente eles não aceitam esse tipo de acompanhamento. Ele é uma criança que precisa de um professor direcionado a ele para acompanhar as atividades. Ele lê palavras bem pequenas, ele consegue identificar, mas você precisa repetir várias vezes... E dizer para ele que ele tem que fazer. Ele é um aluno muito disperso também... Passou alguém ali... Olha ali... 


\section{P: Sim...}

R: Ele não tem uma... Como eu posso dizer?

P: Concentração...

R: Isso! Ele não tem uma concentração naquilo eu ele vai fazer. Se não tiver alguém no lado dele ele não concentra. Então ele precisa daquele acompanhamento. E... Provavelmente assim ele avança nas séries, porque a gente não pode reprovar né? O módulo é... Agora... Você não pode reter o aluno até um certo tipo. É até o terceiro e quarto ano você não pode reter ele. $\mathrm{O}$ sistema aprova. Então... Eu acho que o Joel ele precisa sim passar por uma triagem para que possa desenvolver essas características que ele tem. Que ele não é um aluno que não sabe nada. Ele sabe, mas ele só precisa de acompanhamento.

\section{P: Ele tem autonomia para ir no banheiro? Para fazer as necessidades?}

R: Tem.

\section{P: Sabe manusear a...}

R: Não... Aí ele tem autonomia de chegar lá no banheiro e fazer as suas necessidades... Agora manusear aqueles que é necessário... Lavar as mãos... E essas coisas assim... Ele não tem esse hábito.

\section{P: Vai precisar então do acompanhamento?}

R: É preciso do acompanhamento. Alguém fica lá... Quando ele termina aí tem que dizer: olha, você tem que lavar as mãos; você tem que puxar a descarga; fazer isso... Tá? Porque para ele parece que aquilo tudo é normal. Por mais que professor tente explicar e dizer para ele: olha Joel na sala isso é assim... O lixo tem que fica aqui e isso tem que ficar aqui... Mas ele não tem ainda essa...

P: E com os demais da turma? Tem uma diferença de idade entre eles... 
R: Tem. Ele não apresenta assim... Como é que eu posso the dizer? Rejeição dos demais da turma... Ele se entrosa, ele se envolve com os outros alunos... Ele brinca... Normalmente.

P: A idade dos outros alunos são mais ou menos de quanto?

R: São de quatorze para baixo.

P: Entendi... Então é uma turma de várias idades então?

R: Isso. Temos alunos de uns seis anos de idade até ele que é o dezessete.

P: Na mesma sala?

R: Na mesma sala.

\section{P: Fazendo o terceiro ano no caso?}

R: Não. Aí por que... É assim: temos o aluno de primeiro ano, alfabetização, segundo ano, terceiro ano, quarto ano e quinto ano.

\section{P: Tudo junto?}

R: Todos juntos. Só pela manhã.

P: E como é que você consegue ensinar esses alunos?

R: (Risos) A gente tem que ser o professor artista. Você tem que trabalhar... Divide o quadro quando tem no quadro, leva atividades copiadas... Aí explica para um, passa na mesa do outro... Tem que fazer $0 .$.

\section{P: Então não dá para dar uma aula geral para eles?}

R: Não dá... Não tem como dar essa aula geral para eles...

P: É... Você faz o ensino particularizado de cada um? 
R: É... Porque cada um tem um... A sua série... Então eu tenho que direcionar. O único que eu trabalho mais especificamente é o quarto ano e o quinto ano que já são alunos mais avançados... Que já conseguem ler. Já sabem fazer uma interpretação... Aí esses aí eu tento

unificar o conteúdo para eles. É... Se for muito elevado aí eu já diferencio. Se for um conteúdo que esteja na mesma linha do terceiro ano aí eu já faço junto. Aí já... Alfabetização eu faço separado... Aí primeiro ano eu já tenho outra atividade, segundo ano outra atividade, terceiro ano outra atividade. Aí no caso dele a atividade dele já é específica, já é diferenciada.

\section{P: Então nesse caso... Só tem essa escola lá?}

R: Tem uma escola do município, mas é longe...

\section{P: Então é só essa que eles conseguemacessar?}

R: É. Próximo a casa deles é só essa que eles fazem o acesso mais próximo.

P: E esses alunos conseguem o desenvolvimento para chegar na...

R: Olha, graças a Deus até aqui né? Até aqui todos eles tenham conseguido, mas é um pouco dificil. O professor tem que ser bem artista para... Para esses alunos.

P: E em relação à deficiência? Você chegou a ter alguma capacitação? Alguma ideia para trabalhar com alunos com esse... Essa característica?

R: Não.

\section{P: Você nunca tinha tido?}

R: Não. Nunca tive. Nunca passei. Na realidade foi o primeiro aluno que eu tive contato assim... E... Mas nunca fui capacitada, nunca tive uma formação para isso.

P: E como foi a sua percepção então? Se você não trabalhou com eles? Teria uma necessidade de atendimento especial? 
R: Eu acho que observando ele. Porque nós somos os professores, agente tem que... Eu gosto de fazer uma chamada avaliação com o meu aluno... De observação... É... Tentar fazer perguntas para eles... Observar o jeito dele, como ele age na sala de aula, como ele se comporta... É... Como ele procura apresentar um desenvolvimento nas disciplinas... E aí eu fui chegando à conclusão... Aí sentando, conversando com as outras colegas que já trabalharam... Aí eu sempre notava e ia expondo o que ele fazia de diferente, o que ele não conseguia acompanhar... Os outros alunos... Aí que a gente vai chegando nessas possibilidades de observar, mas formação...

P: Você já chegou a pedir aqui o apoio de algum professor?

R: Já.

\section{P: Para te auxiliar nesse aspecto do aluno?}

R: Já. Infelizmente agora nós não temos, só temos um professor.

\section{P: Que é o professor Batista?}

R: Só ele. É... É difícil porque são muitos no Marta. Aí para atender as outras escolas não tem. Só um professor para trabalhar todas essas escolas aqui... Aí não tem condições. Aí a gente já solicitou desde o momento que nós fomos para lá que a gente detectou... E começou a ver essas dificuldades com ele. A gente chegou com a direção da escola e comunicou, pediu... Mas infelizmente a gente não pôde ser atendido né? Veio o concurso, tiraram...

\section{P: Eles justificam o que para não ter essas condições?}

R: Na realidade é que não tinha professor para ir para lá mesmo. Professores qualificados que tivessem a formação para trabalhar com esses alunos né? Aí essa era a justificativa.

P: Você tem alguma sala? Algum tipo de equipamento ou recurso pedagógico para trabalhar com esse tipo de aluno? 
R: Pouquíssimos. Sala não temos. Nós temos assim os recursos... Alguns recursos...

\section{P: Quais são os recursos?}

R: Olha nós tivemos... Nós temos... Tínhamos né? É que eu não sei agora... Era a professora Dora que me cedia materiais assim... Vários materiais didáticos para mim trabalhar com ele. É... Textos, livros para que eu pudesse manusear com ele, mostrar... Então... É bem restrito. Porque nem sala especial para trabalhar com esses alunos a gente não tem lá. É só uma sala, um... Uma sala de informática, uma cozinha. A área é ampla lá. Assim...

P: $\mathbf{E}$ o contato dele com os demais membros lá da escola? Você acha que existe algum tipo de preconceito lá? As pessoas evitam assim? O que você tem sentido disso?

R: Olha... Em relação aos alunos não existe o preconceito né? Porque até por isso a gente também trabalha muito nessa relação do preconceito. Porque eu sempre digo para eles: todos nós temos a nossa deficiência né? Seja ela lá como for... Mas apresentamos. Então eles não têm assim... Dentro da escola, agora fora da escola alguns coleguinhas, aqueles que... Aí já existe aquele preconceito. Até mesmo de adultos que a gente olha assim e vê de longe assim... Aí dá para perceber...

\section{P: Algum apelido para ele?}

R: Isso. Muito! Apelido é vários... Vários!

\section{P: E tem o que? Chamam ele de quê?}

R: Piu-pira... (Risos).

\section{P: Entendi...}

R: É só apelido assim que... Aí o outro chama de burrinho. São apelidos assim que... Mas ele é uma criança que ele não liga. Chamando para ele, ele está sorrindo... Ele é muito sorridente, ele é muito alegre. Pode estar apelidando... Aí só que também tem os seus momentos né? Porque tem um bom dia que ele chega e ele não quer falar, ele não quer conversar... Aí nesse 
dia nem o professor... Ele diz: ai professora, hoje não. Hoje eu não quero... Não quero saber de nada. Aí tem que deixar ele lá no cantinho dele. Se tiver um lanche eu vou e levo para ele. Ele lancha. Aí eu pergunto para ele se ele quer brincar, se ele quer levar a atividade dele para casa, se ele quer que eu explique... Aí ele diz que não. Aí eu tenho que deixar passar aquele momento dele e tentar conversar, libero... Às vezes eu até libero outra turma, libero as turmas... Aí eu fico lá com ele conversando... Tento brincar com ele, às vezes faço jogos para mim brincar com ele. Que é para ver se ele passa aquele momento. Mas eu conversei com os pais e eles me disseram que ele também na casa dele tem dia que ele não fala com ninguém, que ele não interage né? Com ninguém... Mas ele diz que é por momento... Passa um mês... Aí volta de novo assim.

\section{P: E... Você já tinha ouvido falar nessa política educacional para crianças com deficiência nas escolas públicas?}

R: Não. Falar a verdade... Não. Muito assim... Que eu às vezes eu converso muito com o Batista e... Muito por alto... A gente para pouco em casa e pouco a gente conversa assim... Mas detalhadamente, não.

\section{P: Não foi passada essa política da perspectiva da educação especial para vocês?}

R: Não.

\section{P: Vocês não tiveram nem palestra nesse sentido?}

R: Nem palestra. Nesse sentido não. Nunca... Para falar a verdade não. A única professora que ia e tinha essas ações era a professora Dora, mas ela já está aposentada aí.. Não tinha. Não repassavam, nas escolas, para a gente, cursos... Essas coisas... Nada tinha, nada tem na realidade. Ainda não tem. Posso dizer assim: ainda não tem. São N professores que trabalham aqui com esses alunos, atendendo essas necessidades dos alunos, mas que nenhum tem uma formação para explicar como se deve trabalhar com esse aluno... Como se deve agir dentro de sala de aula. Até mesmo no ensino médio, porque eu tenho vários alunos que têm essas características. Mas nunca... Eu acho... Pelo que eu vejo nenhum dos professores ainda teve essa política. 
P: Você entende que os professores é... Tem alguns que têm dificuldade com o atendimento desses alunos?

R: Muito. Tem...

\section{P: Tem plano?}

R: Reclama. Não... Essa é... Essa é a reclamação geral de nós professores. Nós todos. Às vezes a gente senta na sala... Olha eu estou com dificuldade nisso... E a gente tem que lutar por isso... Aí a gente vai, mas infelizmente as nossas vozes ainda não são ouvidas nesses aspectos. Mas aí a gente tira dúvida com um, o colega auxilia o outro na dificuldade... O que um sabe passa para o outro... Aí vamos pesquisar, vamos saber como agir, como fazer... Porque é a única forma que a gente tem para trabalhar com esses alunos.

P: E os familiares? Como é esse contato de vocês com esses familiares? Eles têm ajudado? Vocês acham que eles colaboram?

R: Alguns colaboram. Alguns pais... Eles são muito colaboradores. São... A minoria é que não aceita, que não participa, que não interage com esse aluno para saber... Aí muitas das vezes ele até critica o professor... Mas é a minoria. São pouquíssimos. Mas a maioria interage muito bem.

P: Nesse caso do aluno... Do Israel... Não é isso?

R: É o Joel...

\section{P: Do Joel...}

R: Nesse caso do Joel os pais dele... Eles não interagem. Eles não aceitam. Que eles diz que ele é assim por que... Porque ele é assim. Para eles é normal... Aquela atitude dele, aquela forma dele ser... Para eles é normal. Aí eles não aceitam.

P: E no caso do Joel? Está a quanto tempo frequentando a escola que você tem formação? 
R: Olha... Ele frequenta a escola desde a idade dos sete anos de idade. E aí ele só... Na realidade ele só conseguiu avançar porque o sistema agora não pode reter né? Então ele tem que avançar. Mas se fosse antes do sistema... Ele já vinha estudando há muito tempo... Ele está com dezessete anos e está fazendo o terceiro ano. Que é uma segunda série hoje em dia né? Aí tem toda essa dificuldade.

\section{P: Então ele está a mais ou menos uns nove anos estudando na escola?}

R: Isso.

P: E... Vocês sabem que tipo de desenvolvimento... Seja... Seja seu desenvolvimento intelectual, seja no seu desenvolvimento de autonomia... Ele efetivamente teve? Você observando e conversando com os demais professores e a própria família?

R: Eu acho que foi no... No intelectual dele assim... Eu acho que ele desenvolveu mais. E até a relação mesmo com a familia que eles me contavam né? Me contam que... Eles não eram... Com a familia... Ele não é muito de ficar em casa, ele é um pouco isolado da família. Ele não brinca com os irmãos assim em casa, ele gosta de estar só. Então ele é uma pessoa assim muito... Como é que eu vou the responder? Ele prefere brincar com outras crianças do que dentro de casa com a família. Eu não sei se porque também ele... Por ser o mais velho assim, dos irmãos... E... Os irmãos apelidarem. Mostrarem uma diferença entre eles. E ele procura um pouco se isolar. Mas dentro de sala de aula ele não mostra essa característica. Já... Ele só apresenta em casa.

P: Na realidade lá da escola então... Você acha que... O quê que precisava para melhorar o atendimento desses alunos? Se fosse possível? O mínimo necessário...

$\mathrm{R}$ : $\mathrm{Eu}$ acho que mais um professor para trabalhar com turma diferenciada e um apoio especializado para ele. Para que ele tivesse esse acompanhamento e esse desenvolvimento. Que ele tem a capacidade de desenvolver, só que ele precisa que alguém esteje lá com ele. Para ele avançar mais. Ele precisa desse acompanhamento, acho... Não é totalmente um professor específico só para ele, mas que possa doar mais tempo para ele, para estar conversando, estar explicando, expondo para ele... Né? Que aí ele precisa disso... 
P: E na sua experiência pessoal? É... Vendo esse aluno como o Joel e outros... Você acha que esses alunos com deficiência intelectual, com deficiência... Ele tem condições de frequentar a sala regular? Você acha que é possível dar algum tipo de atendimento e de autonomia para essas pessoas?

R: Olha... Alguns sim... Pode frequentar uma sala regular e estar lá com os alunos, mas outros não. Não são todos que têm essa possibilidade. Mas a maioria tem essa possibilidade de ir para sala sim, regular.

P: Esses que você disse que não... É... Quais seriam as características que você acha que dificultam?

R: Assim... Eu acho que o entrosamento. Assim... Porque tem aluno que ele não se entrosa na turma. Então isso dificulta... Né? Ele fica arredio, ele não tem colega... Aí por que... Se ele tem um colega na sala ele vai ter um apoio para ajudar ele a resolver suas tarefas e aí... Até mesmo... Mas se ele não tem esse entrosamento dentro da sala de aula, aí ele não consegue avançar.

P: Você acha que... E que tipo de atendimento caberia nesse caso? Seria... Ele não se adapta à escola comum... Qual seria a alternativa? No seu pensamento...

R: Acho que criar assim um... Uma sala assim... De apoio para eles que nem era antes... Assim... Para ele ter um acompanhamento lá na sala e aquele professor trabalhar com ele naquela sala... Como ele se socializar numa sala com os ditos normais? Porque às vezes o professor também se esquece de dizer para aquele aluno que ele precisa se socializar, ele precisa estar lá... E que aquelas pessoas que estão na outra sala são iguais a ele... Tem a mesma perspectiva de querer avançar. Então eu acho que isso seria um trabalho específico fora daquela sala para tentar colocar ele dentro daquela sala com mais facilidade.

P: Você não acha que também trabalhar com os outros alunos que não têm deficiência? Sensibilizando eles também dessa...

R: Hum... Muito importante! Seria ótimo que fizesse também esse acompanhamento com esses alunos. 


\section{P: Tanto de um lado como do outro.}

R: Tanto de um lado como do outro.

\section{P: Você acha que isso melhoraria?}

R: E muito! Isso avança. Avança com todos os alunos. Porque quebra... Porque ainda existe o preconceito né? É pouco, mas tem. Mas quebra uma barreira, porque quando você coloca um aluno que tem uma dificuldade dentro da sala de aula com aquele dito normal, ele é olhado... Alguns olham diferenciado para ele. Até mesmo os professores... Às vezes olham com esse olhar diferenciado. Ah! Porque ele apresenta mais dificuldade, ele é mais lento, ele não consegue acompanhar as disciplinas... E aí volta aquele... Eu acho que o ideal é o acompanhamento primeiro por um professor, para ele saber como ele vai trabalhar com essas duas turmas... Tanto desse dito normal, como esses alunos que... É chamado necessitado de educação especial né? Para depois colocar esses alunos juntos dentro da sala de aula. Creio eu que nunca foi feito esse trabalho, porque eu nunca passei por ele né? É... Com esses professores. Vamos chamar... Olha você vai trabalhar assim com todos esses alunos, tanto com esses especiais como... Vamos unir. Essa é a forma de trabalhar. Você não pode discriminar um aluno porque ele é especial. Você não pode discriminar esse aluno aqui. Então vamos incluir ele. Todos juntos! Essa é a dificuldade. E nós não tivemos esse olhar para ver isso... Não é só colocar o aluno na sala de aula e pronto. Otha o aluno especial ele vai estar inserido. Qual o cuidado que tiveram com isso? Não apresentou nenhum cuidado. Coloca-se um aluno especial numa sala que tem trinta alunos ditos normais... Né? Não houve esse cuidado. É implantar o sistema? Implantou o aluno... Mas olhar... Com aquele olhar que deveria ter... Não foi olhado para ele e nem para o professor... Que enfrenta uma barreira... E muito! E eu é que o diga! E eu é que sei a barreira que tenho para enfrentar... Por que... E quando o professor trabalha só com uma turma ainda tem lá os seus benefícios... No meu caso que eu tenho seis! Só em um horário... Aí eu tenho que desenvolver tudo e dar conta do recado, porque eu preciso que meu aluno... A minha meta é o meu aluno aprender. Então a gente tem que se desdobrar... Para ser...

\section{P: E você acha que tem tido retorno em relação a esse teu atendimento? Seja com seus alunos... Principalmente com... Esse aluno com necessidade especial...}


R: Tenho. Posso the garantir que tenho tido retorno. Até pelos esforços dos próprios alunos eu tenho tido um bom retorno. Né? Então... É dificultoso, mas a gente dá para ver que o retorno vem e aí dá mais vontade de trabalhar né? Mas aí... Mesmo com as dificuldades eles conseguem chegar ao nosso objetivo.

\section{P: Então tá Alba... Muito obrigado pelas suas informações. Você quer falar alguma coisa a mais em relação a essa questão da política? Ou em relação também à situação do professor atualmente?}

R: Não. A única coisa que eu gostaria de acrescentar é que nós professores... Seja do ensino médio até na Universidade né? Deveríamos ter um acompanhamento total... Uma explicação... É... Cursos direcionados a isso. E a gente poderia ter e ser preparado para receber esse aluno em sala de aula.

P: E isso... Acredita-se que a SEDUC não tenha proporcionado... Exige, mas não dá essas condições...

R: Não dá essas condições. E quando se tem... Você tem que tirar do seu bolso para... Quando você tem aquela... Tempo disponível... Você tem que tirar do seu bolso para ir lá e bancar... Seu curso. Para você trabalhar com esse aluno. E eu acho que deveria ter tido esse cuidado, porque antes de inserir esses alunos, trabalhar com o professor, mostrar essa dificuldade, buscar recursos com os professores... Para colocar esse aluno lá. Fazer um trabalho com professor especializado para que o professor pudesse chegar na sala de aula e estar apto à trabalhar com esses alunos.

\section{P: Ok. Obrigado Alba então...}

R: Tá ok. Eu vi vocês dois... Acho que não vou para Urubuoca. Acho que já vou com vocês. 


\section{ENTREVISTA}

Data: 25 de agosto de 2015

Local: Escola Estadual Marta da Conceição - Anexo Urubuoca - Distrito de Icoaraci Belém / PA

Entrevistada: Professora Kátia Regina Cardoso da Silva

\begin{tabular}{l|l}
\hline SÍMBOLOS & LEGENDA \\
\hline $\mathbf{P}$ & Pergunta ou fala do entrevistador \\
\hline $\mathrm{R}$ & Resposta ou fala do entrevistado \\
\hline Itálico & Compreensão duvidosa \\
\hline (0min 0seg) & Trecho não compreensível \\
\hline$\ldots$ & Pausa na fala \\
\hline
\end{tabular}

\section{P: Se apresente...}

R: Tá... O meu nome é Kátia Regina Cardoso da Silva. É... Pelo estado... É... Contratada pelo estado eu já tenho... Eu já vou fazer 23 anos né? Mas antes de eu ser contratada pelo estado eu já fazia um trabalho com a comunidade há quatro anos antes. Quando eu fui contratada eu já tinha trabalho de quatro anos aqui. Porque quando eu cheguei aqui na ilha de Urubuoca não tinha escola e nem professor. E aí eu comecei um trabalho de alfabetização com as crianças né? E eu comecei aqui... Na época... De alfabetizar cento e trinta crianças. E daí eu comecei a correr atrás. Porque essas crianças não tinham como progredir né? E ter um documento que comprovasse é... A série ou o ano que eles estavam né? E eu corri atrás para conseguir um... Uma escola para cá. Para... Até porque para essas crianças terem uma documentação e ter um... Que comprovasse a série que eles realmente estavam e serem... Progredirem dentro da... Do... Da Educação né?

P: E então a senhora mora... Morou aqui? Isso e... Quer dizer: isso começou como compromisso pessoal seu? A questão de educar essas crianças...

R: É assim... É... Porque assim... Eu já... Eu casei com um nativo daqui da ilha né? E a minha mãe também já era moradora daqui. Minha mãe mesmo, biológica. Mas os meus pais de 
criação... Eu era de Belém. E aí como eu vinha passear aqui eu conheci o meu... Meu digníssimo marido né? E aí... É... Eu me casei com ele. E quando cheguei aqui não tinha. Eu vim passear, eu não vim para morar. Já vim mais pra passear na casa dos pais. E aí eu vi que não tinha escola e aí a mãe dele começou a me... Conversar comigo, entrar num acordo de eu vim alfabetizar as crianças... E aí eu comecei só com os filhos dela, que eram meus cunhados e aí ela começou a chegar tantas das pessoas para... Para esse fim né? E aí eu não achei porque não conseguir é... Não, não, não... Não entrar, não lutar pela... Pela essa comunidade que até hoje eu luto né? Luto pela melhoria. Hoje eu já moro aqui já... Já, é... É... Fiz minha casa mesmo. Mas eu tenho toda uma história da minha vida aqui na... Não foi assim não... Rápido não. Para mim me mudar aqui de vez. E continuo fazendo meu trabalho aqui na comunidade, já fui destratada três vezes né? E todas as três vezes que eu fui destratada, eu corro atrás, e volto. A gente conseguiu a escola. Quem fez a primeira escola aqui, foi o meu marido e meu cunhado. E eu comecei a trabalhar pelo estado, mas com o prédio que eu construí junto com meu marido e meu cunhado né?

\section{P: Qual é o nome do seu marido?}

R: É o Moacir.

\section{P: Moacir de quê?}

R: Moacir Pantoja da Silva.

\section{P: Ele faz o quê?}

R: Hoje ele é Barqueiro. Ele presta serviço né? Para a escola né? Como Barqueiro. Porque ele fazia tudo... Aqui na escola quem faz é ele. Quem organiza, quem ajeita, quem... Quem me ajuda aqui é ele. E aí eu... A gente conseguiu um serviço para ele. Para ele... Ele era pescador...

\section{P: Sim.}

R: E de serviço prestado aqui na escola... Ele trabalha. Ele sempre me ajudou aqui na escola. 


\section{P: Então essa escola aqui é... É... De madeira que é... Nessa situação... É mantida por...} Agora pelo estado também? Foi reconhecida?

R: É. Porque aí depois disso em 2000, o estado construiu. Essa escola aqui já foi construída pelo estado. A antiga escola que era nossa...

\section{P: Sim...}

R: Que foi nós que construímos... Eu com o meu marido e um cunhado meu que ajudou...

\section{P: E aí reconheceu...}

R: Isso. E aí ela... É... Eu só consegui é... Trabalhar. Na verdade o prédio não tinha. O prédio era nosso mesmo. Que nós construímos junto com a comunidade, com ajuda... A gente construiu um prédio e eu fui até a SEDUC, junto com a diretora da Marta da Conceição...

\section{P: Isso quando?}

R: Isso foi em mil... Acho que mil novecentos e... Noventa... Por aí assim...

\section{P: Sim...}

R: Noventa mais ou menos... E aí a gente conseguiu. Quer dizer: a gente já vinha numa luta desde 88, mas aí eu... Já vou... E fui conseguir já... É... Com essa diretora, que ela andasse comigo. E em 1990. Aí nós começamos. E antes disso já estava... Desde 1988 já fazia um trabalho dentro da comunidade. Já assim... Alfabetizando as crianças... Mas assim... Era um trabalho assim... Em vão entre aspas, porque eu não tinha uma documentação para comprovar a escolaridade. A escolaridade que eles estavam, mas eu estava alfabetizando eles. E eu já tinha alunos bem avançados né? Que é... Se eu tivesse como dar um documento já estava... Já tinha até o quarto ano, quinto ano naquela época que era... No caso a quarta série né? E a terceira série. E aí a gente com muita luta a gente conseguiu. Em 1993 eu consegui a minha portaria. Saiu a minha portaria para eu trabalhar pelo estado aqui. E aí nós começamos no prédio que nós tínhamos construído. Junto também com a comunidade de... Que eu sempre me virei, fui assim uma pessoa que foi muito virada com a comunidade de... De associação de 
Cotijuba... Eles conseguiram me dar uma antiga madeira de uma creche e com o dinheiro nosso, o recursozinho nosso, a gente construiu a escola.

\section{P: A escola então...}

R: Aí esse prédio aqui já é da SEDUC que foi... É do estado. Que o estado construiu em 2000 esse prédio aqui.

\section{P: E tornou anexo à Escola Marta da Conceição?}

R: Anexo à Escola Marta da Conceição.

\section{P: E agora então a senhora fica responsável pela... Por essa parte da educação fundamental aqui?}

R: É. Eu fico responsável. Eu sou a responsável aqui dentro da Ilha de Urubuoca. Aí tudo que se diz ao anexo Urubuoca eu sou a responsável. Levo para o diretor e o diretor assina e eu também atesto né? Eu sempre fui a professora responsável daqui. Já saí daqui... Como eu estou the dizendo: eu já saí três vezes daqui da escola...

\section{P: Mas aí retorna?}

R: Mas aí eu retorno... Porque aí... É... Quando chega essa parte de compromisso muitas das vezes as pessoas que vêm de fora não têm como... Não conhece essa realidade e aí, às vezes, se torna muito difícil para dar prosseguimento nos estudos. Porque aqui é bom ter uma pessoa aqui do lado. E aí como eu já estou aqui do lado... Eu já tenho a minha casa, eu já moro aqui né? Eu sempre luto para mim voltar. Até porque hoje eu já sou pedagoga, eu tenho especialização em educação especial... Porque eu peguei vários alunos especiais... Então eu fui me... É... É... A fundo. Fui me especializar para mim trabalhar com essas crianças dentro daqui da minha comunidade. Porque na verdade eu quero ficar aqui né? Me aposentar.

P: Na verdade... A grande... É... Finalidade da pesquisa é esse atendimento ao aluno com necessidades educacionais especiais. Desde quando então a senhora começou a tomar pé 


\section{da... Desse... Desse trabalho com esse aluno... Principalmente com deficiência intelectual...}

R: Olha... Essa... Esse é... Que a gente atende a criança... Que eu atendia crianças aqui já era... De muito tempo, só que eu não tinha... Eu não era especializada para trabalhar. Eu ficava aqui a mercê da sorte. Trabalhando da forma que eu é... Eu via que dava. Eu mesma ia atrás, eu pesquisava né? Para trabalhar. Depois eu via essa necessidade de eu me especializar mesmo... Com alunos... Porque quando eu já comecei a atender o Sidney, que era cego... Aí começou a minha preocupação de correr atrás. Até porque na escola sede tinha professor referência, tinha professor de Educação Especial, mas não consigo chegar aqui porque devido a essa... Essa dificuldade de transporte.

\section{P: Isso em que ano?}

R: Isso, mais ou menos, no ano... De quê? Já de 2000 para cá... 2000, 2001, 2002...

\section{P: A sua especialização é de que ano?}

R: Ah! Minha especialização? Olha que eu... Eu já tinha... Eu fiz a primeira né? Aí eu não concluí devido a eu não ter condições de estar chegando até à cidade...

\section{P: Mas na primeira a senhora já... Teve contato com a política da Educação Especial?}

R: Já! Já!

\section{P: Foi em que ano?}

R: Ai... Eu acho que foi, mais ou menos, em 2002 eu acho... Em 2001... Mas eu sempre ia para formações né? Como eu tinha alunos especiais aí a diretora ela me indicavam para formações... De Educação Especial. Eu sempre me envolvi né? Porque eu chegava com ela, eu colocava a situação e ela... E tudo que é formação que tinha... Graças a Deus era uma ótima diretora! Os outros diretores comigo... Eu não tenho que me queixar de nenhum diretor. Eles sempre me ajudaram muito. Porque eu também ia a fundo... Olha: eu estou com essa dificuldade... 


\section{P: Quais eram as maiores dificuldades para o atendimento desses alunos?}

R: A maior dificuldade mesmo era a... A prática. Para saber como que eu... Que eu não tinha prática de como é trabalhar com eles né? Porque eu tinha alunos que, vamos dizer assim: que eu, eu trabalhava com eles a leitura e usava de todas as estratégias... Alguma coisa tem! E eu não conseguia identificar né? Esse menino alguma coisa tem... Porque como é que eu já fiz de tudo e não consigo que ele aprenda né? Eu ficava pensando... Aí eu me sentava com os pais e os pais também não tinha conhecimento... Aqui na ilha são pessoas assim que não tem... Que não tem uma, uma... Um conhecimento né? Da... Da situação. Para eles é... Por exemplo, um aluno que ele tem dificuldade, que é déficit intelectual, o pai acha que não, que isso aí é besteira, que não existia isso... Ou até mesmo, por exemplo, eu tenho essa aluna que ele é deficiente múltipla. Depois de muito tempo foi que... Que a mãe veio colocar na escola, que ela pedia para vir... Tanto é que ela já tem quarenta e poucos, quase a minha idade... E ela gosta demais de vir para escola né? $\mathrm{E}$ devido... Eu acho que ela, às vezes, custava... Deve demorar muito para vir para a escola. Até hoje ela não conseguiu assim... Ter um aprendizado mais né? Por isso que ela quer vim. A gente dá todo o apoio. Sabe? Tem todo carinho com ela. Que é a Isabel. E tem toda aquela... E a mãe diz: ah! Vou tirar a Isabel, porque até agora a Isabel não conseguiu nem escrever o nome dela. Aí tem um tempo assim que ela avança sabe? Aí tem um tempo que ela regride de novo sabe? E até hoje mesmo, às vezes, eu fico com um pouco de dificuldade, porque a gente não tem aquele apoio total...

\section{P: E das... E das crianças que a senhora atende atualmente? De três anos para cá...}

R: Ah! Essas crianças... Você fala em relação a quê?

\section{P: A deficiência intelectual. Esse atraso, às vezes, de ter dificuldade de aprendizado...}

R: Olha... Tem é... É só uma, ou duas... Aliás, agora eu estou com mais uma aluna, que ela já está no quinto ano, que ela já veio... Já para o quarto... De outra escola para o quarto ano. Para cá... Que a avó tirou para... Porque todo mundo diz assim: olha vai para Urubuoca que a professora... Assim.. Quem não aprende com a professora Kátia não aprende mais com ninguém por aqui. 


\section{P: Certo...}

R: Então eu tenho uma referência muito grande dentro disso aqui. Dentro das ilhas aqui... Porque eu atendo cinco ilhas e todo mundo dá essa referência. Aí eu, às vezes, fico até um pouco chateada... Digo: poxa! Depois que vocês experimentam as crianças em todas as escolas, aí vocês veem que não tem jeito, e trazem para mim né? Porque alguém indica. Olha: põe na escola de Urubuoca que tu vai ver só...

(Risos)

R: Como ela vai já se alfabetizar... Que a professora lá, ela é ótima! Aí eu tenho essa referência... Então é por isso que a escola aqui ela atende cinco ilhas. E é o anexo que tem mais alunos. A gente, matriculados, a gente tem 47 alunos. Matriculados com documentação toda comprovada. 47. Agora a gente vai ganhar mais cinco alunos agora...

P: E agora com a necessidade de educações especiais... Do primeiro ao terceiro ano... A senhora tem quantos?

R: Olha... É que tem Lauro e tudo... Eu estou só com dois agora... Que já saíram...

\section{P: E o quê que a senhora observa?}

R: Que eu observo... Eu acho que eu tenho... Que tem mais uns três. A minha própria neta, ela tem essa dificuldade.

P: Certo... Isso...

R: E aí eu estava até querendo transferir ela... Porque ela veio estudar com meus netos...

\section{P: E esses três seriam que...}

R: Intelectual...

\section{P: E estão em que série?}


R: Olha... Uma está no quinto ano...

\section{P: Sim...}

R: É que ela já veio de outra escola... Como eu estou the falando né? Que eu tenho essa referência. E a minha neta ela está no terceiro ano.

\section{P: Certo. E o terceiro?}

R: E o outro ele está no... Terceiro... Quarto ano.

\section{P: Certo.}

R: Quarto ano. Assim... Em séries diferentes...

P: Então tu já tem acompanhado esse e a sua neta e o outro desde o primeiro ano então?

R: É... A minha neta desde o primeiro ano.

P: Aí eles têm uma dificuldade de aprendizado?

R: Tem...

P: Tem um ritmo mais lento que os outros?

R: Lento... Lento... Aí agora que eu consegui que a minha... Que a minha...

P: Que métodos a senhora usa para poder? A senhora flexibiliza? Em relação aos outros...

R: Olha... Não... Eu vou... Em relação aos outros eu vou tentando vários...

\section{P: Tem uma diferença?}

R: Uma diferença... Faço uma diferença... 


\section{P: No atendimento?}

R: Faço uma diferença. Geralmente eu trago atividade diferenciada. Olha: hoje eu quero que vocês levem pra casa isso aqui, vai fazer... Aí ensino direitinho. Geralmente quando não dá pra mim fazer dentro da sala de aula naquele momento... Porque eu trabalho com multisserie. É muito difícil né? Trabalhar com multisseriado... Porque você está trabalhando ali com... Além de estar trabalhando aluno com... De vários níveis né? Já né? Já porque a gente já pega os alunos né? As séries... Os anos diferentes né? Já pesou o mesmo... Para mim desenvolver é... Os conteúdos diferenciados, planos de aula diferenciados... Aí eu faço um plano de aula já adaptando... É para cada... Para cada ano entendeu? Que eu faço. Aí eu sinto assim: não tenho mais dificuldade porque já tenho muito tempo de experiência e dá certo como eu trabalho... Da forma como eu faço. Como eu the falei ali. Olha: uns estavam escrevendo nome que você viu lá né? Montando o nome com material... Com... Com... Com alfabeto móvel... Outro já estava escrevendo textos... Formando textos né? Sobre o Dia do Folclore... Textos variados... Parlenda e outros trava língua... É... É... É... Com o alfabeto... Quer dizer, quem já conhece o alfabeto e já está alfabetizado ou então está em um em um nível alfabeto... É... É... É... Silábico. Alfabético... Aí eles já vão já montando... Eu já não me ocupo muito. É bem pouquinho. Quando eu chego lá que eu vou fazer a correção. Olha aqui... Que letra é? Vamos ler aqui... Como estava fazendo ainda agora. Aí os outros eu já estou trabalhando o nome deles, trabalhando as palavras que eu ditei para os meninos... As palavras doces, do caso da parlenda... Vamos escrever o doce. Para uns eu fiz. Aí eles não conhecem. Tem uns que não conhecem as letras ainda. Aí aqueles que não conhecem a gente vai trabalhando. Quer dizer, é muito bom esse trabalho aí. É um trabalho assim.. Que eu vejo assim... Eu, pelo menos, né? Tem que ter muita paciência, mas eu vejo assim que dá muito resultado em eles conhecerem as letras do alfabeto para aqueles que não... Que ainda não conhecem... Eu consigo um avanço bastante. E para outros eu já consigo assim, por exemplo, que tem dificuldade na leitura, que estão se alfabetizando... É rapidinho que eles conseguem a ler quando eu coloco o texto pequeno para eles montarem com o material. O móvel...

\section{P: Em relação a esses alunos com deficiência intelectual a senhora diz que, às vezes, quando não dá... A senhora dá no outro turno então?}

R: No outro turno. Eu dou apoio em outro turno por minha conta mesmo... 


\section{P: À tarde?}

R: À tarde... É... Eu peço para eles virem. Converso com as mães e digo: olha dá para ele vir à tarde? Porque à tarde, por exemplo, meus alunos a maioria deles que são alunos daqui dessa escola aqui, que foram desde pequenos... Já dominam a leitura. Do quarto e quinto ano. Que eu já peguei de outra escola. Eu tenho dificuldade. Porque geralmente quando eu pego no quarto, quinto ano de outra escola o aluno nem está alfabetizado. Aí como já tenho um espaço e os meninos já... Já conseguem ler... É... Fazer as atividades... Aí eu já venho com esses meninos, pego essas crianças... Dois, ou três, ou um... Dependendo de quem é que vem. Eu vou mandando cada dia vim um. Aí eu já trabalho com eles nesse horário. Com eles assim... Aí já vem trabalhando. Aí eu tenho tido avanços... Sabe? Mas é...

\section{P: A senhora acredita então que esses alunos com deficiência intelectual possam ter um desenvolvimento?}

R: Olha, eu acredito. Porque a minha neta ela é... Ela já é... Dois anos que ela estava repetindo o terceiro. Já estava no segundo ano repetindo o terceiro ano. E essa semana eu fiquei tão feliz quando eu dei um texto que ela leu todinho. Foi... Ela errou assim, umas duas palavras... Aí eu disse: ai meu Deus! Eu agradeci tanto a Deus... Até me ajoelhei à noite né? Porque eu pedia tanto para mim conseguir né? Com que ela... Ela... Ela lesse. Eu consegui que ela... Quando ela... Quando eu vi ela lendo assim... Eu fiquei assim muito feliz... Porque estava já assim... Resolvendo já liberar ela para a escola. Para ir para Icoaraci... Para ela ter outro atendimento muito melhor. Porque aqui a gente tem... Não tem um outro professor para me ajudar no caso de Educação Especial. Agora que a gente está correndo atrás né? Então eu fiquei tão feliz assim... Porque surtiu efeito os trabalhos que eu estava fazendo né? E com a outra aluna de quinto ano também...

\section{P: Quer dizer: se a senhora tivesse um apoio melhor... Uma... Condições melhores... A senhora... Com certeza esses alunos teriam um desenvolvimento é...}

R: Eu acredito nisso né? Eu acredito... Eu estou pedindo a Deus. Quando o diretor me disse que ele estava indicando... Isso... Que ele ia até colocar para me ajudar... O Batista... Que eu disse: poxa! Agora essas crianças vão é... Vão ter um desenvolvimento bem melhor. Eu 
acredito sim. Que eu tenho muita dificuldade... Olha: o aluno que é cego... Ele canta, ele faz oração, mas quando ele chegou aqui comigo... Que ele é sobrinho dela... Ele não pegava nem no copo para tomar água, ele não sabia pegar. Tinha que dar tudo na boca dele. Ele era totalmente dependente. Hoje ele já tira o fechecler... Abre o fechecler e faz xixi... Segura... Eu só, mais ou menos, direciono ele. Ele já faz xixi sozinho, ele já come sozinho... Que na casa dele ele não comia. Ele já come. Só que ele... Ele tem dificuldade, ele é epilético... Aí de vez em quando... Ele adoece muito. Aí ele geralmente... Ele falta muito, mas acho que se ele não faltasse muito ele já sabia fazer muita coisa. Até o andar... Ele andava... O andar dele é... É todo assim... Ele tinha dificuldade. Porque a gente mora aqui nas ilhas. Essas casas elas são pequenas. A gente não tem para onde andar. Olha... Aí a criança... Se ela não...

\section{P: Existe uma dificuldade de acessibilidade?}

R: Isso. Dificuldade... Aqui não... Já... Ele vinha pra cá, eu colocava ele para correr... Sabe? Eu tinha todo um... Só que nessa época eu era de Educação Especial mesmo, as minhas 200 horas eram voltadas para eles. Aí agora eu voltei para a sala de aula, mas mesmo assim eu não deixo. Eu sempre tiro um tempinho para mim com as crianças. Quando ele está aqui eu digo: olha, bora que hoje nós vamos brincar um pouco lá. Para mim estar fazendo essas atividades com ele... Diferenciada... Que seja para ele. Que é como...

\section{P: Para dar uma mobilidade?}

R: Isso. Para ele correr, para ele ter... E hoje ele já pega, ele já chega, ele já sabe onde é a cadeira dele... E eu consegui assim.. Bastante avanços com ele.

\section{P: Então a senhora tem certeza que tendo uma estrutura melhor a senhora teria... Não só a senhora, mas esses alunos poderiam ter um desenvolvimento mais...}

$\mathrm{R}: \mathrm{Eu}$ acredito. Eu acredito por que...

\section{P: Quais condições?}

R: Sim. É claro que sim! 


\section{P: Então a senhora acredita nessa política?}

R: Acredito. Acredito... Acredito porque, como eu estou the falando, esses...

\section{P: Tu achas que esses alunos têm que ficar a parte ou tem que ficar na classe comum?}

R: Com certeza eu acredito.

\section{P: Como os demais?}

R: Com os demais. Mas com o apoio de alguém. Porque eu acho assim: que se eu tivesse... Tivesse o professor itinerante na sala de aula e ele fosse um professor itinerante... Aquele responsável... Porque também tem aqueles que não... Que eu já tive professores assim. Que nem ligava... Já veio... Já, já... Já houve uma época aqui... Professor... E eu ficava assim... Muito triste. Por que... É tipo assim... Eu não tinha. A professora estava ali, mas não tínhamos apoio. Agora quando... Da outra vez eu tinha uma técnica que ela era... Que era a professora referência. Ela me ajudava muito, ela vinha para sala de aula...

\section{P: Qual que era a professora?}

R: Professora Dora Estela. Ela já aposentou.

\section{P: Sim...}

R: Ela vinha para sala, ela me ajudava muito... A professora Dora Estela. Entendeu? E ela vinha... Eu via assim um compromisso dela dentro mesmo da... E da Educação. E ele avançou muito, e ela que me ajudou o Sidney a avançar. E até a Isabel mesmo... Entendeu? Até Isabel mesmo a avançar... Só que a Isabel ela é bem interessada. Só que o problema da Isabel são vários... Não é só um. A Isabel ela é intelectual, ela é... Ela é... É, é, é... Tem problema né? Visual, auditiva... Sabe? Ela tem todo esse... Ela tem todas essas dificuldades a Isabel. Mas até ela mesmo, a Isabel... A Isabel ela é muito interessada, ela tem vontade de fazer, mas... É assim... É... Hoje ela está bem, a Isabel. Eu acho assim: se a Isabel tivesse vindo mais tempo para escola, eu acho que a gente teria conseguido... 
P: Então a senhora acredita que, por exemplo, essas crianças com deficiência é... Vindo desde tenra idade é mais fácil para...

R: Mais fácil.

\section{P: Para trabalhar...}

R: Mais fácil para trabalhar. E eu ainda vou the dizer uma... Com sinceridade... Eu ainda não fiz, mas a minha maior vontade é tirar. Porque tem crianças que moram aqui dentro das ilhas que não vão para escola porque a mãe tem vergonha que a criança vá... Entendeu? Que não... Não foram ainda... É... Inseridos na escola, ainda não foi... Os pais não têm essa visão... E eu... Se eu tivesse mais tempo eu iria atrás dessas crianças para que elas chegassem.

P: A senhora tem conhecimento de que tem crianças que estão segregadas em casa?

R: Tenho. Isso. Que os pais não... Não trazem por esse motivo. E se...

P: Porque não acreditam que vão ter...

R: É... Não acreditam né? E aí eu tento... A própria mãe da Isabel disse: Kátia eu não vou mais mandar a Isabel. Só que a Isabel briga para vim.

\section{P: Sim...}

R: Eu cheguei a conhecer... Ela briga.

P: Ela tem uma informação... Trabalho com famílias...

R: Também. Falta. Também falta.

P: Acreditarem que a escola possa...

R: Isso.

P: É... Ajudá-los na autonomia dessas crianças... 
R: Com certeza. E essa professora, a Dora Estela, eu queria que tivesse, pelo menos, umas... Umas dez professoras que nem ela. Muito... Uma... Eficiente mesmo. Ela ia na casa dos pais, ela conversava e sentava... Uma ótima! Ótima... Ótima professora, pena que já aposentou né? Mas, às vezes, eu digo para ela: volta Dora Estela porque a gente está precisando de você...

(Risos)

R: Quem dera que ela pudesse voltar né? Mas poder, ela pode né? Não sei se ela ia querer... Mas é isso aí...

P: A gente ainda vai conversar. Que eu ainda vou voltar aqui. Mas a senhora gostaria de falar alguma coisa no final? Sobre esta questão específica do atendimento des ses alunos com necessidades educacionais especiais...

$\mathrm{R}: \mathrm{Ah}$ !

\section{P: O que falta... O que a senhora acha... Pensa inclusive...}

R: O que eu penso é que a gente precisa... Nós... Por exemplo, eu preciso de um professor para me ajudar. Um profissional da Educação Especial. Se hoje eu já me especializei, mas eu já tenho que trabalhar dentro da minha sala de aula... Que você vê... Que eu trabalho como multissérie. É difícil. Eu trabalho mais com eles, eu tento fazer da melhor forma possível para que eles... E eu consigo... Assim... São avanços como eu the contei agora da minha neta que estuda aqui, da Juliana que ela veio do quinto ano... Aí eu peguei e disse: Juliana tu estais lendo Juliana? Continua me ajudando. Olha... E eu... Ela já leu um pouquinho essa semana agora e eu já fiquei feliz. Porque a avó dela disse: minha filha ela não lia nada. E agora ela começou a ler. Frases assim... Lê... Ela está no quinto ano. Aí ela veio me pedir e ela disse: professora eu não quero ir para a Marta da Conceição, me deixa mais um ano aqui que eu acredito que eu vou aprender a ler como a senhora. Aí depois eu vou... Porque eu vou fazer o quê no quinto ano lá professora? No meio... Ela me pediu essa semana. Ela já é mocinha. Ela tem 13 anos. 13 anos... 12 ou 13 anos que ela tem... Aí ela me pediu essa semana agora passada. Que ela disse que não quer que eu... Que eu... Ela tem que avançar né? Ela já ficou o ano passado retida. Porque ela já veio de outra escola... Ela disse: ah! Professora me deixe 
esse ano. Não deixa eu ir para a Marta da Conceição, eu quero ficar aqui. E aí.. O que eu tenho para finalizar, o que eu tenho a dizer é que a gente precisa de uma pessoa especializada dentro das nossas escolas. Aqui, por exemplo, aqui no anexo Urubuoca eu não tenho mais uma pessoa. Eu preciso que me ajude.

\section{P: E a estrutura também né?}

R: E a estrutura né? Que agora a gente já está correndo atrás né? Da nossa... Dizendo o diretor que já vai ser... Eles já vão já... Estão se mobilizando já né? Para organizar a escola. Que eu venho lutando desde 2008 para uma escola nova. Eu venho lutando desde 2008. Uma luta! E todos os consertos, as coisas que tem aqui quem faz sou eu mesma. Sou eu que faço tudo aqui.

\section{P: Parabéns professora pela sua dedicação, pelo seu trabalho... A gente vai...}

R: Eu gosto do trabalho que eu faço viu?! Eu gosto demais.

P: Eu venho lhe visitar na próxima vez que eu vir aqui... Aí se eu tiver alguma pergunta, alguma dúvida a mais... Eu espero que a senhora me responda.

(Risos)

R: Tá certo

P: Mas eu fico muito agradecido pela sua colaboração nessa minha pesquisa...

R: Tá bom. Eu espero que... Eu já fui alvo de muitas pesquisas. Aqui de vez em quando as pessoas vêm aqui... Só que não me trazem um retorno. Assim sabe? Olha professora...

\section{P: Nós traremos aqui...}

R: Um retorno. Mas é... Eu estou aqui para ajudar né? E também se eu... O que eu tenho a pedir assim... Se tiver alguma coisa nova que pode dizer: olha Kátia! Eu trouxe para lhe ajudar... Para te... 
P: Sim.

R: Eu aceito. Porque eu até aqui... Eu estou sozinha né? Então eu preciso de ajuda.

P: Obrigado.

R: E o meu diretor ele é responsável. Ele está aqui. Ele é legal.

P: É... Nós estamos aqui com o apoio dele...

TEMPO TOTAL $=23 \mathrm{~min} 13 \mathrm{seg}$ 


\section{VÍDEO}

\section{Data:}

Local: Cotijuba - Distrito de Icoaraci - Belém / PA

Entrevistado: Estudante Felipe Ambé

\begin{tabular}{l|l}
\hline SÍMBOLOS & LEGENDA \\
\hline $\mathbf{P}$ & Pergunta ou fala do entrevistador \\
\hline $\mathrm{R}$ & Resposta ou fala do entrevistado \\
\hline Itálico & Compreensão duvidosa ou palavras em Latim \\
\hline (0min 0seg) & Trecho não compreensível \\
\hline$\ldots$ & Pausa na fala \\
\hline
\end{tabular}

R: É... Eu sou... Sou Felipe Ambé. Sou... Estudante de Pedagogia. Estou nos últimos... No último período de Pedagogia. Estou quase me formando. É... E atualmente eu sou coordenador discente geral do projeto "Para a leitura vai quem quer". Projeto esse que desenvolve e incentiva a leitura. E também aborda temas como educação ambiental e educação sexual para as crianças da ilha de Cotijuba. Nosso principal locus de trabalho é uma escola anexo que fica na comunidade do Poção. É... Do outro lado da ilha. Digamos assim... Bem isolada. Já para a comunidade... Indo um pouco mais para a comunidade do Vai Quem Quer. E a gente desenvolve na escola anexo da Marta da Conceição. É... Escola Pedra Branca. Escola anexo Pedra Branca que é uma escola, por sinal, multisseriada, ainda por cima...

\section{P: Eu acho que esse... É melhor o... Ficar para cá...}

TEMPO TOTAL $=54 \mathrm{seg}$ 


\section{ENTREVISTA}

Data: 3 de fevereiro de 2016

Local: UTEES - Cotijuba - Distrito de Icoaraci - Belém / PA

Entrevistadas: Coordenadora Irene Maciel, Professora Lucilene Duarte, Técnica Sandra Ferrari.

\begin{tabular}{l|l}
\hline SÍMBOLOS & LEGENDA \\
\hline $\mathbf{P}$ & Pergunta ou fala do entre vistador \\
\hline $\mathrm{R}$ & Resposta ou fala das entrevistadas \\
\hline Itálico & Compreensão duvidosa ou expressão latina \\
\hline (0min 0seg) & Trecho não compreensível \\
\hline$\ldots$ & Pausa na fala \\
\hline
\end{tabular}

\section{P: Já!}

R1: Eu sou a professora Irene Maciel atualmente eu estou na coordenação da UTEE de Icoaraci. Eu estou aqui desde o dia 3 de agosto. Então eu posso falar, nesse momento, do trabalho a partir desta data, mas antes da gente começar a delinear essa questão eu vou fazer assim... Um pouco do papel da UTEES quando ela foi criada né? Na verdade a UTEES ela foi criada na década de 70 . E ela surge nesse momento aqui no distrito de Icoaraci... Ela surge... Para dar esse suporte técnico-pedagógico às escolas que tenham esse alunato né? Como inicialmente ele só tinha uma política voltada para o assistencialismo... Então... Vamos se dizer que a... A função era dentro dessa linha do assistencialismo né? Já estava se iniciando todo esse processo da inclusão né? Mas a gente ainda estava no processo ainda da integração nesse momento que a UTEES ela inicia esse trabalho. E aí de 98 a UTEES ela reformula esse trabalho por conta do processo da inclusão que de 94 para cá, com a Declaração de Salamanca, que foi um documento que impulsionou todo esse movimento da gente modificar a organização do sistema para... Para receber esse aluno. Porque lá, no início, era o aluno que tinha que se preparar para adentrar o sistema de ensino. Com a política da inclusão ele... O sistema de ensino tiveram que se preparar né? Para se organizar internamente... A sua proposta pedagógica, os seus passos para receber esse aluno. E aí foi neste momento que a 
UTEES precisou também rever né? A... O seu projeto político-pedagógico. E nesse momento a UTEES, eu posso dizer, que ela tinha uma equipe de trabalho para desenvolver. Porque do concurso para cá e até, mais ou menos, eu acredito, que 2000, 2001... Esse processo foi quando ele ficou latente. A inclusão desses alunos na rede regular de ensino. E aí todo esse formato de formação continuada foi o momento que a UTEES... Vamos se dizer que tenha sido o carro chefe da UTEES na formação dessas escolas pertencentes à Icoaraci. Inclusive eu sempre vinha participar. E essa formação ela não se restringiu somente aos professores da Educação Especial, ela se restringiu... Ela também era ampliada para os professores do regular. Tanto que a COES que é o órgão articulador da Educação Especial no estado do Pará... A... A... A COES ela fez umas formações, vamos se dizer, em massa. Nós tivemos o... O "Conhecer para Colher"; o "Educar Pará na Diversidade", que não só... Não ter... Teve como meta atingir não só atingir os professores da Educação Especial, como também, os professores do ensino regular. E durante todo esse processo... De 97 que a primeira classe inclusiva aqui no estado do Pará foi a escola Costa e Silva. Ela foi a primeira a escola a ser convidada a ser implantada a primeira classe inclusiva. E depois em seguida foi o Jarbas Passarinho do Souza e nos outros anos consecutivos ampliaram para mais das escolas. Elas foram na verdade, vamos se dizer, as escolas piloto, experimental... Para esse... Para essas turmas inclusivas. E conforme o avançar... Já que a gente sabe que o processo da inclusão ela é positivada em lei. Foram surgindo decretos, foram surgindo resoluções... Que ampara toda essa... Esse público no sistema regular de ensino. Então as escolas começaram, de modo geral, a se tornarem inclusivas. Mas inicialmente começaram com toda essa escola. Então por conta dessa ampliação desse alunado nos sistemas de ensino nós tivemos estes momento. Mas, vamos se dizer, por questões que... Vamos se dizer... Mesmo de política de governo de estado e pelas condições que a gente tem hoje... Porque até o concurso daí... Que nesse primeiro momento não havia, não houve nenhum concurso de 94 até 2012. Que teve o concurso Educação Especial. Esses profissionais que estavam trabalhando na Educação Especial eram profissionais que não tinham nenhuma vantagem em trabalhar com esse público. Estavam trabalhando porque se identificaram com trabalho né? E esse público começou a aparecer nas escolas e eu comecei a olhar esse sujeito de uma forma diferente, mas eu não tinha nas minhas vantagens enquanto professor... Ganhar $50 \%$ por estar atendendo essa clientela. E a gente... E todo mundo que trabalhava era por realmente por... Gostar... E não tinha assim essa formação, vamos se dizer, inicial... Tanto que eu... Quando eu fiz o curso de Pedagogia na minha grade curricular que era antigamente... Era especialista... Eu não vi uma disciplina que se tratasse de Educação Especial. Tudo que eu construí de conhecimento na área da Educação Especial, até 
a presente data, foram porque eu fui trabalhar com esse alunado... Senti necessidade... E como naquele momento quando eu... Em 92 quando eu iniciei esse trabalho era... A gente teve formações direto né? E com pessoas que já estavam atuando e que tinham experiência e que serviam de... Assim... De apoio para nós que estávamos iniciando. E a maioria... É...

\section{P: Não havia o reconhecimento formal?}

R1: Não havia um reconhecimento formal, apesar de muitas lutas... Ainda na década de 90 tivemos... Tivemos por... Descobrir que a gente, por trabalhar com esse público, teríamos direito a esse... A essa... A essa gratificação... 25 professores né? 24 professores deram início a uma... Como é que chama? Pleiteando isso na justiça para ganhar os 50\%. E aí as... Os primeiros professores que passaram a ganhar essa gratificação foram os professores que entraram a nível judicial. Esses 24 professores... E aí depois de muito tempo... Já com esse... Com essa... Com esse... Eles abriram precedente e o nós que estávamos, que não haviam entrado judicialmente, passamos a ganhar esse 50\%. Mas a gente sabe que a mudança de governo para um outro muitas vezes para em determinadas políticas que estão acontecendo. E quando são de partidos diferentes... Assim... A gente sente esse impacto maior... Então aquela política de formação, e eu digo que lá nesse período de 2000 a 2001, o carro-chefe da COES, da Coordenação de Educação Especial, era a formação continuada de professores da Educação Especial e do Ensino Regular. E nos últimos anos a gente tem percebido que a gente não tem conseguido dar conta dessas formações por falta de recursos financeiros para montar um encontro desses de professor e encontro de gestor e por falta de pessoal para trabalhar nessas formações no sentido de ter disponível para estar organizando. Inclusive era isso que nós estávamos avaliando... O nosso papel enquanto unidade especializada. Porque inicialmente a gente tinha um formato de uma equipe de trabalho que pudesse dar conta de uma formação. Porque a USE... A UTEES... Ela tem sob a sua jurisdição as escolas pertencentes... Pertencentes a USE 11, 12 e 13. Somando as... As escolas que pertencem a essas três USE... Dá cinquentas escolas... Das cinquenta escolas e uma unidade especializada, que é a nossa. São 51 espaços educacionais. Vejam: cada espaço desse tem uns... Deve ter em média 70, 80 professores trabalhando. Então some o quantitativo... A dimensão de profissionais que precisam estar neste processo de formação contínua... Do professor do regular que está na regência e está com esse aluno incluído na sua turma, como o professor que está realizando atendimento educacional especializado precisa dar esse suporte, tanto não só para o aluno... Quanto também para o professor. E hoje por essas dificuldades que eu 
acabei de falar: falta de recursos financeiro, a falta de uma equipe para poder organizar todo esse trabalho... Eu digo que a formação continuada, não só a nível de Icoaraci como... Para quem conheceu o trabalho antes como eu, que já estou 24 anos... Estou completando, agora em maio, 24 anos só na Educação Especial. Eu não passei por outro segmento. Eu comecei a minha vida profissional na Educação Especial. E dizendo assim... Quando eu assumi a primeira turma de deficiência mental com 15 alunos eu chorei desesperada... Porque eu não sabia o que fazer. Porque ali tudo para mim era novo. E eu acredito, sem medo de errar, que aconteceram com demais profissionais porque naquele momento não se tinha uma visibilidade desse público e do trabalho que era desenvolvido com eles. E aí foi tudo uma construção realmente de conhecimento. Mas hoje a gente pode... É... É... Acontece as formações... E são com verbas... Estamos agora... Vamos ter um a nível de governo federal. Que veio verbas... Para essa formação, vamos se dizer, que vai... É... Desde 2000...

R2: 2008.

R1: Desde 2008 que tá vindo essas verbas, mas a gente enquanto unidade especializada por conta... Por essas questões que eu acabei de elencar nós não estamos conseguindo que... Inclusive a gente estava discutindo agora na nossa reunião de avaliação... Qual será o papel da unidade técnica daqui para frente?

\section{P: Há quanto tempo você fez a última formação?}

R1: A última formação nós fizemos... Em dezembro agora... Dia 5 ou foi dia 4 ? Dia 4 de dezembro nós fizemos a última formação.

\section{P: Mas conseguiram...}

R1: Mas só para a educação... Hein?

\section{P: Mas conseguiram abranger todas essas unidades?}

R1: Abrangendo... Foi convite para todas as escolas dessas unidades... Dessas USE... Sendo que para colocar isso em prática eu precisei lançar mão da equipe de professores. Porque eu não tenho uma equipe técnica. A única equipe... Que é técnica ali é a Sandra. O resto tudo é 
professores... Tivemos que otimizar o nosso trabalho como professor e dar conta dessa atividade que estava prevista no nosso calendário de... De ação né? Para este ano de 2015.

\section{P: Não existe uma obrigatoriedade de todos os professores participarem?}

R1: Da... Das outras?

P: É...

R1: A gente... Nós fazemos o convite e fazemos o trabalho de conscientização da importância dele participar das formações no sentido de estar trabalhando o aperfeiçoamento com esse professor. Porque não existe... Não existe didaticamente é... A nível bibliográfico... É... Coisas estabelecidas. Cada aluno que aparece, esse público que aparece... Ele... Apesar de ter as mesmas... Por exemplo, eu tenho cinco alunos autistas, mas cada um apresenta características diferentes. Então o que funciona para Lucilene pode não funcionar para a Irene. Então é um... É uma constante... Processo de formação que você precisa buscar para que você possa lidar com os prejuízo que esse aluno a presença... Apresenta no seu desenvolvimento né? Enquanto indivíduo. Enquanto ser humano. Então a gente percebe que hoje essas formações ela... Elas estão... Elas estão ainda em falta com este... Com este professor atualmente. Mas elas estão acontecendo. Vamos se dizer, de uma forma ainda muito tímida... Não como acontecia anteriormente... Mas hoje a USE 12 ela está com uma proposta de uma ação unificada. O que é essa ação unificada? O que estará acontecendo em uma escola estará acontecendo simultaneamente em outras escolas. Sendo que dando o formato de acordo com sua realidade. E uma das formas que eles pensaram, uma das ações unificada, foi a questão da... Da... Da Jornada Pedagógica. Geralmente a Jornada Pedagógica ela consegue... Ela acontece em cinco dias após o recesso do professor. Três dias acontecerá internamente em cada espaço e dois dias será unificado. Será em um espaço onde vai abrigar todos os professores né? Tanto do regular como da Educação Especial... Dois dias numa formação de acordo com... Com o que vai ser lançado enquanto temática para esse dia. Não... Ainda não se tem porque a gente vai ter inclusive uma reunião dia 15 agora. Nessa reunião do dia 15 cada... Cada diretor vai ter... Não, aliás, cada grupo de escolas referência em níveis de ensino vão ter que apresentar um projeto para essa ação unificada. Já está pronto das... Das escolas de primeiro ao quinto ano. E a UTEES precisa, também nessa reunião, apresentar a proposta dela de um fórum na questão dessa formação que vai implícito dentro desse... Desse projeto. E... Nessa... E nesse primeiro 
momento de discussão... De discussão das escolas... É... Como nós somos transversal a todos os níveis de ensino eu quero estar com uma temática voltada para a questão da flexibilização curricular. Eu sinto, eu vejo na minha experiência de... De professora também... Porque eu sou professora né? Na minha experiência de professora eu percebo que o... A... A escola ela tem dificuldade de fazer adaptação curricular para esses alunos. Principalmente dos professores de ensino médio. Eles têm a maior dificuldade de fazer essa flexibilização. E minha proposta inicial, só que eu ainda não discutir com o grupo, eu preciso ouvir o grupo, é levar nessa formação unificada, neste fórum, a questão da temática da flexibilização curricular. E já vai ser delineado nessa reunião do dia 15. Então a gente percebe que é também... Até os sujeitos que trabalham hoje na Educação Especial eles são outros sujeitos. Por quê? Você começou falando assim: a partir de 2012 com o concurso C167 foram outros profissionais que adentraram no mercado, outros professores. Com outras visões... Pessoas mais jovens. Nós somos antes do concurso. Éramos todos temporários... Tá? Iniciamos na educação Especial com um contrato de um ano. De 92 para cá... Todos nós temos mais de 20 anos, mas todos temporários. Hoje nós somos efetivos. Foram únicos que conseguiram sobreviver a essa guilhotina que foi o concurso. A maioria dos nossos colegas que estavam atuando conosco foram demitidos, foram exonerados... Porque não tinham 20 anos. E os demais que tinham acima de 20 anos, pelo UNTAC. Que até hoje a gente não sabe se existe, se foi assinado... Foi garantido na rede, mas no ensino regular. Nós somos o que conseguimos sobreviver. Fomos aprovados no concurso e vamos ficar até a nossa aposentadoria. E então... Vejam que hoje a Educação Especial está com um grupo de professores que iniciou o processo da integração, viveu todo aquele processo da integração, passou pela... Está vivendo a inclusão... E temos um grupo que está iniciando a partir do processo da inclusão. Então veja que nós vamos ter vamos ter uma... Vamos ter dois grupos né? Com perfil diferente e por isso... Por isso que hoje eu consigo ver. Eu tenho essa leitura doutor Macieira... Que nós temos um outro perfil de profissionais e estamos também desencadeando um trabalho bem diferente que foi construído lá na década de 90.

\section{P: Dentro desse perfil você entende o que? Quem teria mais sensibilidade? Nesse aspecto assim...}

R1: Sem medo de errar doutor Macieira... Fomos nós que iniciamos sem nenhuma gratificação. 
R2: A classe especial marcou a gente...

R1: Marca a nossa vida porque estava ali quem realmente gostava de fazer o trabalho. Não vou dizer também que eles estão ali...

\section{P: Sim...}

R1: Mas eu vejo que a procura... O que levou... Tanto que é... Hoje os cursos de especialização eles estão sendo procurados em massa a questão da educação inclusiva. Você não vê hoje... Eu vim... Eu vim de uma... Eu vim de uma especialização de gestão. Era muito o que tinha na época quando eu fiz... Gestão, psicopedagogia... Mas educação inclusiva não tinha. Eu fui... Porque que eu fui fazer especialização em Educação Inclusiva? Porque como o concurso veio e um dos critérios para você ser... Não era ser só aprovado, mas apresentar a nível de documento... Você apresentar uma especialização na área da Educação Inclusiva. Eu corri pra fazer, apesar de já ter especialização. Mas eu precisava, senão eu não assumiria o cargo. Então veja que até o que era ofertado no mercado a nível de especialização não tinha Educação Inclusiva. Hoje se você abrir a... Os cursos que são oferecido na área da Educação Inclusiva, em todas as Universidades, você vê que ela está voltada... Até porque na verdade... Também o cenário... Porque a gente sabe que o currículo escolar, como o senhor colocou, ela tem uma das características... Características principal que é a relevância social. Então se hoje a relevância social é a questão da inclusão, esse currículo... Eles têm... Ele tem que estar voltado dentro dessa visão de uma educação inclusiva. Então você tem o currículo escolar e tem... Esse currículo escolar ele tem que estar voltado para essa visão holística que é essa visão do todo né? Não é aquela... Aquela concepção realmente fechada de currículo. Então... Aí hoje nós vamos pautar as nossas práticas, nós vamos... É caminhar na área da Educação Especial com essa visão holística de um currículo em que eu vou ter uma visão desse todo né? E do indivíduo que está ali. Que devido aos prejuízos que ele tem no seu desenvolvimento ele não dar conta de acompanhar, mas eu vou precisar ajustar esse currículo escolar para que ele possa realmente... É dar conta de alguns conteúdos que estão previstos para aquele aluno, naquela série.

P: É... Eu... O foco maior que eu tenho aqui é no ensino fundamental, principalmente da primeira à terceira série. Aquele momento crucial para o aluno da alfabetização... $O$ primeiro contato, a estimulação e... É um dos momentos mais difíceis, principalmente 
para o aluno que chega com deficiência intelectual. É o... De que... De que forma está sendo feito o planejamento? De que forma vai... Está havendo abordagem em relação à...

R1: Deve ser... Deve ser... Porque a gente sabe que o que é... O que deve acontecer... O que deve ser o ideal né? Mas a gente muitas vezes não sabe se é o real que acontece. Já que essas primeiras... Esses anos iniciais trata-se de você trabalhar e... Iniciar, desenvolver a habilidade da leitura e da escrita. E os outros últimos anos você vai só consolidar isso. Então se ele está iniciando essas habilidades de leitura da escrita e como nosso aluno ele tem um prejuízo nessas áreas de... Principalmente o aluno com deficiência mental. Aonde é que é a grande dificuldade para ele acompanhar esse currículo? O que está sendo desenvolvido no processo da leitura e da escrita? Ele tem a dificuldade de estruturação mental do seu pensamento. É um processo mais lento. Enquanto você para um aluno que não tem uma deficiência mental você consegue trabalhar com ele em um dia, em dois dias, um conteúdo... Com esse aluno, devido a essa fragilidade intelectual que ele tem né? Ele demora mais tempo. E aí nós vamos precisar com eles trabalhar de uma forma... Porque ele não consegue ter uma organização estrutural... Acomodar aquele conteúdo, aquele conhecimento... É... Na sua capacidade. Porque ele tem a dificuldade na metacognição. É a capacidade de pensar. De ele formular... Para que ele possa chegar aqui e dizer aqui: esse... Isso aqui é azul. Então ele precisa... Para ele chegar à conclusão desse conhecimento que isso é azul ele precisa ter a capacidade de pensar, que é a metacognição. Que é um mecanismo que o indivíduo tem para que ele possa aprender. Além da memória, além da motivação, além da concentração e da atenção; ele tem a transferência e a metacognição. Então esses mecanismos que todo indivíduo tem, como qualquer um de nós... Nós mobilizamos para construir um conhecimento. No aluno com deficiência intelectual esses mecanismos funcionam de uma forma mais lenta, principalmente o processo da metacognição, que é a capacidade dele pensar, dele formular esses pensamentos... Aí o professor que está iniciando esse processo da leitura e da escrita com ele precisa criar situações de aprendizagem concreta para que ele possa desenvolver essa metacognição. Que eles têm a dificuldade de concentração, de atenção... Então vão ser atividades específicas em sala de aula, principalmente a visualização de determinada situação... Para que ele possa formular, que ele possa levantar em hipótese e construir o seu próprio conhecimento. Então deve acontecer dessa forma...

\section{P: É... Pois é... Eu... Eu... Eu acompanhando a situação lá... Alguns aspectos lá da escola... Ela tem duas viés... Tem a Escola Marta da Conceição que é no centro onde nós}


temos... Para a gente lá... As salas de aula divididas: primeiro ano, segundo e terceiro. Com os professores lá fixos né? É... Nós temos também problemas lá. Professores nem sempre tem... É... É... Diz que não tem uma capacitação continuada lá. Alguns né? E alguns... É... Não estavam preparados para lidar com aquele aluno e não tem também, pelo número de alunos na sala... É... E aí tem os relatos das mães dizendo que nem sempre tem a paciência necessária. Exatamente para esse tempo do aluno. É esse tempo do aluno né? Aqueles que precisam de um mais... De mais tempo. E já nos anexos... Como tem o caso lá da professora Kátia. Que lá é multisseriado né? Aí já... Você já tem alunos da primeira, segunda e terceira série na mesma... Todos juntos. E quando a professora dá uma atenção maior para aquele aluno isso já causa um problema com os outros alunos. Quer dizer, são duas realidades diferentes né? É... Mas de qualquer maneira acaba prejudicando... É essa... É esse aspecto da pessoa com deficiência intelectual. Vocês têm observado isso? E aí? O segundo ponto... Que como lá na Marta da Conceição nós ficamos... Nós tivemos um vácuo de... De professores da... Na Educação Especial... Com a saída da Dora até a chegada, por exemplo, do Batista e da outra professora. É... A professora... Os pais eles atestam que com a chegada do professor da Educação Especial, principalmente com o estudo no contra turno, eles... Os alunos tiveram uma... Uma melhora no seu desenvolvimento né?

R1: Na verdade doutor Macieira eu vejo assim... A política ela veio... Esse movimento, na verdade, ele veio. As leis estão aí... Mas o quê que ainda está faltando? Na verdade os sistemas de ensino eles não estão preparado ainda, como eles deveriam estar. Por exemplo, lá eu não conheço a realidade que o senhor está colocando lá na ilha... Classes de multisseriada. Como é que eu digo? Que lá na legislação diz assim: que eu tenho que ter uma redução... Redução de $10 \%$ de um aluno com deficiência dentro daquela turma. Se eu estou com uma classe multisseriada? Está contradizendo totalmente o que a legislação está dizendo. E porque que elas são multisseriadas? Porque nós não temos escolas... Se aqui eu tenho, em média, quatro alunos... Que é no centro da cidade, aqui no distrito de Icoaraci. Eu estou com um pepino na mão para resolver... Está aí a Sandra... Eu estou em média com quatro alunos autistas numa classe regular...

P: Que tem quantos alunos? 
R1: Que deve ter em média... Se é de primeira... Se for uma turma de segundo ano, tem em média 30/35 alunos. Vejam: o professor tem que dar... Isso é só numa série... Agora pense, doutor Macieira, numa classe multisseriada...

\section{P: Pois é... Isso que... E eu vi lá... A situação...}

R1: Numa classe multisseriada né? Que ele tem ali alunos... Se ele tiver 10 alunos, ele tem um de primeiro ano, segundo ano, terceiro ano, quarto ano e o aluno com deficiência intelectual... E se... Se eu trabalho com classe multisseriada eu trabalho com diversidade de conhecimento aí... De construção desse conhecimento e mais um aluno que apresenta uma necessidade específica para construir essa aprendizagem... Veja o quanto esse professor vai ficar en-louque-ci-do... Então vejam que a... A política ela veio. A legislação ampara, porque a educação inclusiva ela é positivada em lei. Porque ela vem baseada na... Na... No princípio maior dos Direitos Humanos: independente de qualquer situação, eu sou... Eu sou humana e tenho direito a aquilo ali... A ser... Estar dentro do sistema educacional, ter direito à saúde, direito à educação...

R2: Com qualidade...

R1: Com qualidade!

\section{P: Com qualidade...}

R1: Mas como, de fato, doutor Macieira? E tenho certeza que já chegou muito na sua mão...

\section{P: Sim...}

R1: Processos que a escola recusa a matrícula do aluno. Ela não recusa. É porque ao receber aquele aluno ela precisa ajustar o seu espaço, tem que dar acessibilidade do currículo, acessibilidade do espaço, dar condições para esses professores trabalharem... Como é que eu vou? Se eu já tenho quatro, vai chegar mais um, são cinco... Como é que eu vou ofertar um trabalho de qualidade? Só que quem trabalha na área que está julgando não conhece a realidade da escola. Sabe que muitas vezes nós não estamos negando porque estamos discriminando aquele aluno... É porque realmente a gente não vai dar conta. Mas é um sistema 
todo que não está dando condições. Porque a lei é clara... Ela diz lá: os sistemas de ensino... Qual é a lei Lu? Que tu lembra bem... Os sistemas de ensino devem organizar-se para receber os alunos. Devem se organizar-se, mas nessa organização vai... Vai ser organização de espaço, as condições desse professor... Então em uma classe multisseriada, doutor Macieira... Como dar conta de um sujeito que apresenta característica diversa na área do seu desenvolvimento? Com o sistema que a gente tem aí...

P: É... É aquela grande... É...

R1: Que o governador não me ouça, senão eu fico desempregada...

P: Não... É... Mas...

R1: Não grave isso!

P: Não... Mas é o grande nó... Mas isso aqui é para a pesquisa... O grande nó é a diferença... Diferença entre inserir e incluir.

R1: É...

\section{P: Não é?}

R1: Só estão inseridos... Alguns só estão inseridos.

P: É...

R1: Não estão incluídos de fato.

\section{P: Que a inclusão ela...}

R1: É a garantia desses direitos na íntegra. Qualidade de um... De um currículo, qualidade de ele estar dentro da escola, a garantia de acesso dele... Tudo com qualidade. Porque a lei é clara: acesso, permanência... E permanência com o quê? 
R2: Com sucesso...

R1: Com sucesso! Três palavras básicas... Básicas da política da Educação Especial na perspectiva da educação inclusiva.

P: E inclusive você falou uma coisa... Que é uma das coisas que eu... Que eu me preocupo. É a questão da flexibilização. Mas como flexibilização? Isso eu... Eu... É uma das coisas que eu tenho dificuldade de... De... De verificar na prática.

R2: Isso...

P: Né? Como flexibilizar se o próprio sistema...

R2: Fecha.

P: Ele já chega... E... E...

R2: Ele fecha uma matrícula...

R1: Matricular...

P: É...

R3: Com determinados conteúdos, para determinado nível, para determinada etapa. Né? Então aí se o professor... Aí... Eu não sei se eu posso me meter...

R1: Pode! Deve! Eu já falei muito...

\section{P: Então você coloca o seu nome...}

R3: Eu sou Lucilene Duarte. Né? Eu trabalho na Educação Especial desde 2000. Já fui professora de alfabetização. Fui professora de quinta à oitava série na disciplina de História. E estou atuando atualmente... A... Agora na Educação Especial né? Como tudo isso que a professora Irene já colocou... Nós vivenciamos na prática isso né? E com relação à 
flexibilização curricular ou adaptação curricular, como também alguns autores colocam... É a questão da falta realmente de conhecimento do professor regente. Porque vejamos... Nós não fomos formado para atender um público diverso, nós fomos formados para atender um público homogêneo. Entendeu? Eu parto do pressuposto de que o senhor está neste nível de conhecimento. Então é a partir daqui que eu vou começar. É o alfabeto, é as vogais, é as consoantes, é o encontro consonantal, palavras com dificuldade... Esse é o nosso currículo. Já vem pré-estabelecido...

\section{P: Eu que tenho que me ajustar... $\mathrm{O}$ aluno...}

R3: Eu que tenho... Eu que tenho que me ajustar. Né? Quer dizer que quando chega um aluno que tem um tempo... Necessita de um tempo diferenciado para aprender, tem um ritmo diferenciado, tem uma perspectiva diferente... Ele não vai ficar no sistema. Ele vai ser excluído do sistema. Se o professor não tiver essa sensibilização... Porque eu não vou nem conscientizar, eu vou sensibilizar... Professor nós temos um aluno que tem uma deficiência intelectual, ele precisa que o conteúdo que a senhora vai passar hoje, no final, faça a avaliação com ele. Porque amanhã ele já esqueceu. Isso é flexibilizar. Professora se a senhora vai fazer... Fazer o fonema B faça musiquinha com fonema B... A partir da realidade deste aluno, que ele vai ter mais facilidade para estar realmente fazendo essa metacognição, para estar transportando isso para outras... Outros espaços... Comece daí. Traga a vivência dele para a sala de aula. Ao invés de a senhora trabalhar todo o fonema, vamos trabalhar apenas uma parte hoje, amanhã a gente vai trabalhar outro... Para dar tempo de este aluno poder assimilar. Agora o nosso professor regente no final do ano ele tem que dar conta de 200 dias letivos, de uma carga horária de no mínimo 800 horas, com determinados conteúdos... Se ele não der conta desse conteúdo até o final do ano a direção vai chamar atenção. Porque você não concluiu o conteúdo? Né? Porque já vem pré-estabelecido se você abrir o sistema da secretaria você tem lá os conteúdos do primeiro ano, do segundo ano, das etapas de EJA... Entendeu? Quer dizer... E não há essa flexibilização a princípio. Então é a partir de um processo de formação, que como a professora Irene colocou, é toda uma construção que nós temos para desmistificar, para desconstruir a nossa própria formação da graduação. Porque nós tivemos que desconstruir para poder ter este olhar diferenciado. Porque senão você não dá conta da diversidade. Um dos cursos que foi patrocinado pelo... Com recurso do Governo Federal... E que até hoje eu vejo como excelente foi o "Educar na Diversidade". Porque o "Educar na Diversidade" ele traz uma proposta de ir dizer assim: olha se o seu aluno aprende 
melhor através de dados, você tem aqui dados; se o seu aluno aprende melhor através de imagem, você tem aqui imagem; ou seja, dava oportunidade para o professor escolher de acordo com o nível de sua turma. Então foi um dos melhores cursos, que infelizmente, ficou aí pelo... Por questões políticas não continuou né? Hoje nós temos cursos novamente fragmentados né? Porque nós temos cursos do AEE. É somente para o professor do AEE. Se for para o professor regente já é uma outra perspectiva... Por quê? São conhecimentos que a princípio a gente pensa que tem que ser diferenciado. Porque você é a professora regente, eu sou professora da Educação Especial... Ainda não há este olhar holístico... De que nós somos um todo e que fazemos parte da diversidade. Esse é o grande problema. Nós precisamos parar de olhar para este... Olhar homogêneo de que esse menino... Todos estão nesse nível e todos vão aprender o beabá. Hoje todos vão aprender o beabá. Que não é assim na Educação Especial. Então é este conhecimento que ainda precisa ser praticado pelo nosso professor da rede como um todo. Ele tem uma formação fragmentada. Falamos de inclusão, mas toda percepção é fragmentada. Não há esse olhar holístico. A própria graduação... Todas as graduações agora que estão tendo esta visão, por exemplo, eu me formei em 2006 e não tive nenhuma disciplina voltada para Educação Especial. 2006! Nós já estávamos com todo esse processo de inclusão. No máximo... Que nós tivemos na... Na... Na... Na... Na universidade foi seminários. Todo o meu processo de conhecimento da Educação Especial é ao longo do tempo que a gente vem construindo... E aquele... Aquela questão do... De o professor ser seu auto-profissional né? E buscar justamente essa formação continuada por conta própria. Não dá para nós ficarmos esperando... Doutor não dá para nós ficarmos esperando! E infelizmente por conta de todo um pensamento, por conta de toda uma lógica... Nós, eu coloco como nós enquanto toda a... A equipe né? Pensamos que sempre tenho que vim a formação até a mim.. Não. Eu tenho que ir buscar essa formação. Quase todo professor que está na Educação Especial ele começa a partir da sua própria inquietação... Né? Eu tenho que buscar. Não sei ainda como trabalhar com esse menino... Eu tenho que ir buscar... Entendeu? Então foi uma inquietação intrínseca para poder... É aquela automotivação que eu tenho que ter para poder buscar. O nosso... Os professores que chegaram agora do concurso $\mathrm{C} 167 \ldots$ Eu percebo isso porque estava aqui quando eles chegaram no distrito de Icoaraci e muitos que chegaram logo na primeira leva... Como eu também estava nessa levam nós tivemos aqui para recebê-los e hoje o que é que eu posso dizer a partir de todo o processo de formação que Icoaraci vem tentando implementar... Hoje é muito a questão salarial doutor... Perpassa muito pela questão salarial, perpassa muito pela questão realmente do que eu vou ganhar. Diferente da percepção mais humanista que era das colegas que estavam no sistema. Nós nos colocamos nesse 
sistema. Entendeu? Porque nós tínhamos um olhar diferenciado com relação a este aluno. Toda essa equipe saiu. Saiu... Muitos foram destratados, outros assumiram como técnico... Hoje o que está é uma nova equipe... Que claro... O homem é fruto do seu tempo... Então... Vivemos numa sociedade capitalista. Que eu preciso está em uma profissão que eu tenha retorno financeiro. Então eu vou procurar algo que eu tenha retorno financeiro. Diferente da equipe que, até então, estava é... Labutando nessa questão da Educação Especial a nível de Icoaraci e eu digo até a nível de Pará. A nível de Pará.

\section{P: Ou seja, então não há estímulo para vocês procurar uma capacitação... Tem que estudar um pouquinho mais... Se você não vai ter um aumento salarial... É... Mais ou menos isso? Você não tem um estímulo para se capacitar... Para principalmente...}

R3: Na rede... Na rede dificilmente você vê esse auto-estímulo das pessoas estarem buscando a sua própria formação. Existe essa certa dificuldade. Eu tenho que esperar o governo me oferecer a formação. Porque houve muita a questão da especialização na Educação Especial? Justamente por conta do concurso. Né? Na verdade historicamente a gente... O mercado vive... A educação vive na lógica do mercado né? Então foi ofertado por conta da questão do concurso, mas hoje quem está na... Na Educação Especial... Não. Vai ter formação tal... Entendeu? Quer dizer que dificilmente a gente vai buscar uma auto-formação. São poucos os que vão, são poucos os que estão hoje realmente pelo que gostam... Não, eu gosto de fazer isso. Eu gosto de estar com os alunos da Educação Especial. Né? Isso daí é um problema que nós vivenciamos. Hoje é muito a questão financeira. É muito o retorno financeiro. Diferente da equipe que estava...

\section{P: Então essa flexibilização encontra dificuldades na sua prática?}

R3: Encontra. Encontra muita dificuldade pela nossa formação. Nenhuma é... Universidade forma o professor para trabalhar na diversidade. Poucas... Agora já tem mais esse olhar, mas até então... Até 2006 não tinha. O que tínhamos era aquele olhar fragmentado... Você vai ser professora de História. Está aqui o conteúdo da primeira etapa, da segunda etapa... Porque já vem tudo elencado. Tudo bonitinho. Né? Quer dizer... Quando eu cheguei na sala de aula o que é que eu vou passar? Tenho o livro didático como meu suporte, que esse é o principal suporte do professor de sala de aula. É o livro didático. Né? Ainda não conheço a minha turma... Né? Então a partir do livro didático é que eu vou ter como referência. Aí se por sua 
vez não está no projeto político-pedagógico a questão da flexibilização... Olha: você vai dar aula no sétimo ano, mas lá no sétimo ano nós temos um aluno com deficiência intelectual que ele é... Está... Agora que ele está aprendendo a ler e a escrever. Eu sou professora de história, eu vou uma vez na semana nessa sala. Como flexibilizar para este aluno? Se o meu tempo é 45 minutos... É bem complicado. Não tirando... Não podemos colocar a culpa que é do professor regente, mas sim do próprio sistema. É o sistema que é inflexível quando a gente fala de inclusão, quando a gente fala de flexibilização... O sistema é inflexível. Né?

\section{P: Então quando eu falo... Né? Se existe essa previsão de diretrizes operacionais da educação inclusiva no ensino público do estado... É... A resposta seria: nós não temos um...}

R3: Eu enquanto professora...

\section{P: Uma diretriz... É... Uma diretriz...}

R3: É... As diretrizes né? Infelizmente o estado do Pará ele vem... É... Trabalhando de acordo com as diretrizes do MEC. Né? Ano passado ainda estive numa reunião no Conselho Estadual de Educação no sentido de... É... Criar de fato o atendimento educacional especializado no estado do Pará. Como estaria ocorrendo este funcionamento... Porque se o senhor for ver nós só temos na legislação federal. A nível do estado do Pará o atendimento educacional especializado ainda não foi institucionalizado. Nós não temos uma resolução. O que o Senhor trabalha lá na promotoria é apagar incêndio quando surge de uma escola, quando surge de outra... Mas o quê que nós temos de concreto no estado do Pará? Que diga que vai ser assim ou desta forma o atendimento... Que a flexibilização vai ser ofertada através do PARFOR. Né? Vamos fazer agora uma formação para os professores da rede que traga essa perspectiva justamente de educar para a diversidade. Né? Porque perpassa pela questão de educar para a diversidade. Porque eu vou entender que eu tenho negro, que eu tenho um índio, que eu tenho a pessoa que está privada de liberdade, que eu tenho o menino que está na medida socioeducativa, que eu tenho ribeirinho... Que só pode ir para escola dois dias na semana... É trabalhar com esse público. Educar na diversidade é trabalhar com esse público. A partir desse pensamento de que eu vou ter esse público em sala de aula eu vou saber que não adianta eu trazer aqui um texto bonito que a minha turma não vai dar conta. Mas eu tenho que trazer diferente... É... Estratégias para dar conta dessa turma. É uma imagem, é um vídeo, é um... 
Um texto pequeno... Entendeu? É isso que é trazer para dentro da sala de aula diferentes estratégias. Que aí eu vou dar conta dela que ainda está se alfabetizando, vou dar conta daquele outro ali já está em um nível mais adiantado... Entendeu? Quer dizer, são questões que a gente precisa mudar ainda e romper como a questão do homogêneo e sem trabalhar com o heterogêneo. A partir da mudança dessa... Dessa minha visão de que eu tenho um público diferenciado que tem diferentes ritmos, diferente estilo... Nós enquanto seres humanos aprendemos assim. Eu não sei se o senhor aprende melhor ouvindo, eu aprendo melhor vendo... A colega já pode aprender melhor... É... Fazendo um esquema. Então formas diferentes de aprender. Eu não sei se ela está compreendendo a mesma coisa do mesmo modo que eu estou compreendendo. Porque são níveis diferentes de aprendizagem. Se eu partir desse pressuposto de que todos nós aprendemos de forma diferente e que precisamos estar auto-motivados... Aí muda a lógica da flexibilização curricular. Porque isso vai ser parte dos meus princípios enquanto educadora. E não de uma imposição...

\section{P: É... Esse... Esse... Esse documento então... É... Orientativo nós não temos?}

R3: Não. A nível de estado do Pará ainda não doutor. Porque se senhor for ver o que é que nós temos... Os últimos documentos a nível de estado do Pará foi a Resolução 400 que teve todas aquelas controvérsias... Entendeu? Quer dizer que se o senhor... Nós temos toda a Política Nacional da Educação Especial na perspectiva da educação inclusiva, temos notas técnicas, temos resoluções... Aí o MEC emite uma resolução dizendo onde vai ficar a segunda matrícula desse menino... Aí o MEC emite uma nota técnica dizendo como é que esse menino vai para o censo escolar... Mas a nível de Pará... O que nós temos de concreto? Cada um caminha como pode...

\section{P: E a intensidade nossa assim é bem...}

R3: Bem pertinente. Bem pertinente... Recentemente nós estivemos realizando um... Um projeto para a educação de jovens e adultos né? Foi um recurso que veio do Governo Federal para trabalhar com... É... Privados de liberdade, medidas socioeducativas... Quando... Em alguns casos os ribeirinhos... É... O negro né? O quilombola, o indígena... E foi um projeto muito bem pensado porque nós pensamos a partir da diversidade. Olha: o ribeirinho só pode estar na escola segunda, terça e quarta; quinta, sexta e sábado ele tem que fazer farinha, ele tem que fazer isso, ele tem que fazer aquilo... Então nesse dia ele está disponível 
integralmente. Entendeu? O indígena se você levar ele de uma aldeia para outra você precisa dar alimentação para ele e para a família dele toda. Porque ele vai abandonar a aldeia dele... Então nós tivemos que pensar a partir da diversidade. O preso tu só tens... Tu só podes ficar na cadeia para dar aula para ele das treze horas até as dezesseis. Porque depois fecha. É a tranca. Entendeu? Nós tivemos que pensar um projeto. Ele está sendo executado pela Secretaria de Educação. Né? Na Coordenação da Educação de Jovens e Adultos. A partir desta diversidade... É um projeto, eu não sei se o senhor já ouviu falar, de saberes da EJA...

\section{P: E aí... Esse... É esse pensamento que tem que perpassar...}

R3: É esse... Esse pensamento que tem...

\section{P: Para os alunos com deficiência intelectual...}

R3: Como um todo. Porque ele foi pensado também na pessoa com deficiência. Olha: se nós tivermos o aluno com deficiência... Né? Você já vai estar... É... Trazendo à tona realmente a necessidade do aluno. Olha não adianta que eu colocar a aula das duas da tarde às dezoito horas porque o meu aluno ele sai daqui ele ainda vai trabalhar... Ele sai daqui ele vai para a tranca... Quer dizer, isso é pensar na diversidade. Isso é fazer uma proposta curricular adequada à necessidade de cada um. Que nós sabemos que na região amazônica não é pouca e não é fácil... Não é fácil. Né? De professor trabalhar o dia todo molhado porque tem que andar no casquinho para poder chegar até a localidade, de professor ter que levar seu rancho para dentro da aldeia por que ele só vai sair de lá daqui a um mês... Então isso é trabalhar na diversidade. Inclusive já estava se discutindo, a nível de MEC, a possibilidade de que o... A per capita do valor do aluno da região amazônica seja diferenciada... Não podemos é... Colocar de uma forma geral se nós sabemos as situações, as peculiaridades do estado do Pará. Né? Ali nós só podemos passar com o casquinho é... Quando a maré está cheia. Por que quando a maré está seca você tem que dar... Fazer um balão que é $\mathrm{R} \$ 700$ para você atravessar. Isso é pensar na diversidade... Isso é pensar um currículo a partir da região amazônica... Isso é trazer à tona o que nós temos de melhor que é o seu local, o seu espaço... Né? Isso é pensar na diversidade. Aí não precisa a gente falar na flexibilização curricular doutor... Não é preciso porque todos nós somos diferentes... Né?

\section{P: Você teria mais alguma coisa a colocar?}


R3: Não. Obrigada. Já chega...

R2: Falou?

\section{P: Ótimo!}

R2: Depois sou eu que falo né? Depois diz que sou eu que falo... Alguém quer falar alguma coisa?

(Risos)

R2: Nem precisa... Depois...

R2: Se escondeu é?

P: Conceição... Então a professora Irene voltando a falar... Falando especificamente sobre os problemas e as orientações lá para a escola Marta da Conceição.

R1: É essa visita no Marta da Conceição foi para verificar... É... Os alunos. Tá? Por que...

\section{P: Na área da deficiência?}

R1: Na área da deficiência. Da deficiência... Por quê? Porque hoje o professor para ser lotado... A lotação dele está atrelada ao quantitativo de aluno. Se ele tem 200 horas ele tem que ter em média... Aí se for trabalhar... Porque a SEDUC trabalha com mínimo de 8 e o máximo de 12. Então para justificar a lotação dele ele tem que ter esse quantitativo em cada 100 horas de trabalho. Então se ele tem 200 horas ele tem que ter, pelo menos, mínimo de 8, máximo de 12, pela manhã e à tarde ele tem que ter esse mesmo quantitativo para justificar as 200 horas dele. E lá no Marta da Conceição justamente fomos verificar essa situação. Porque nós temos um professor de 200 horas e temos uma professora lá... Parece que ela também... Ela tem 100 horas e está em processo de aposentadoria. Então nós fomos verificar. Fizemos a análise da pasta para ver quem tem laudo... Porque quem tem laudo a gente já sabe que ele é nosso público, aquele que não tem laudo tem uma suspeita e a gente muitas vezes não sabe... Porque o diretor ele queria que a gente verificasse a questão das pastas porque alguns não 
tinham laudo e alguns... Olhando assim.. Tipo assim: lá tem o Síndrome de Down, mas ele não tem laudo. Mas como o Síndrome de Down você olha e percebe as características... Já sabe que ele é o nosso público , mas tem alguns alunos que você não percebe. Então nós detectamos e separamos as pastas que já tem laudo. Pedimos para que esses que não tem laudo fosse orientado à família para que a gente pudesse verificar. Porque algumas daquelas pastas pode ser verificada que o aluno não é o nosso público. Está lá sendo rotulado um aluno com deficiência, mas que não é. Às vezes por uma dificuldade que ele tem de aprender, de processar... Né? O conhecimento dele... E ele está lá como aluno como deficiência mental, intelectual... Ele está lá na turma... E aí se a gente detecta com isso que não tem esse quantitativo de aluno logo... Não... Alguém está sem lotação ali. Porque para a SEDUC o que vale é quantitativo, quadro professor/aluno. Então essa que é a forma... Então nós fomos verificar essa situação e fomos dar algumas orientação de como eles devem proceder para que isso seja... A documentação... Os documentos da Educação Especial desses alunos, na pasta, fiquem todos organizados. Fomos verificar e eles ficaram de... De estar encaminhando isso e verificar... E no final de todo esse levantamento a gente vai ver como é que vai ficar para a lotação 2016... Se cabe mais um professor pelo quantitativo de alunos ou se realmente só o Batista ele dá conta daquele alunado que está lá. Entendeu?

\section{P: E professora... Qual... A senhora poderia dizer as principais pontos que a senhora orientou nesse aspecto?}

R1: Os principais pontos foi: deles encaminharem... Eles reunir com familia, encaminhar as familias para... Para a retirada dos laudos... É... Verificar... É... Porque lá em algumas pastas nós não temos nada de registro de... Que nós chamamos de PDI, que é o Plano de Desenvolvimento do Aluno... Segundo ele... Ele tem isso no computador. Cada plano de aluno individual... Que isso é uma... É um dos instrumentos necessários para o trabalho do professor do AEE.

\section{P: Foi. Isso eu pedi para ele... Os autos...}

R1: E não tem nas pastas. Salvo uns antigos... Né?

\section{P: Certo}


R1: Mas eu disse para ele que a gente precisava ter isso atualizado, mas ele me garantiu que no computador dele, lá na sala dele... Por falta da dificuldade de imprimir porque são muitas folhas e muitos alunos... Isso está tudo no computador. Eu disse que ele precisava verificar toda a situação. Porque isso é... É um documento do aluno e tem que estar na pasta do aluno, por exemplo, agora eu cheguei para fazer...

\section{P: Imprimir e mandar para o pessoal assinar...}

R1: Assinar e colocar...

\section{P: Regularizar?}

R1: Regularizar essa questão do... Do PDI... O plano de trabalho dele... Que a gente... Que ele precisa também para $2016 \ldots$

\section{P: Ele não te deu o plano de trabalho?}

R1: Eu não cheguei a ver, mas ele me disse que ele... Ele... Porque foi aquele tempo que a gente correu tudo para lá. Acabou... Mas o ponto chave que eu fui ver foi a questão desse quantitativo de aluno...

\section{P: E o plano de trabalho?}

R1: E um plano de trabalho. Foi orientado também... Deixa eu ver o que mais... Eles disseram que algumas coisas eles não estavam fazendo até por falta de orientação. Porque essa foi... Do período que eu assumi que foi dia 3... Agora que eu consegui ir no Marta da Conceição.

\section{P: O quê que eles não estavam fazendo por falta de orientação?}

R1: Em termos de orientação assim... Foi essa questão do... Do... Do... Do alunado né? Que eles não estavam colocando nas pastas os... Os PDI... Né? Eles precisam estar com isso tudo colocado no PDI. Foi uma das questões que a gente orientou. E a questão da... Da orientação técnica que foram algumas coisas que eu orientei no sentido do trabalho com o aluno... Como é que eu devo trabalhar... E que a falta da formação que eles sentem... Me colocaram essa questão da formação. Que há muito tempo eles estão sem esta orientação... 


\section{P: Não só professor da Educação Especial, mas os professores da sala regular?}

R1: Da sala regular. Mas como eu conversei com o Batista eles me colocaram... Ele e a outra professora me colocaram essa questão. E aí nós vamos tentar, dentro do possível, ver quando nós tivermos algumas formações por aqui para que eles sejam também... É... Garantidos. E dentro do possível, por falta de uma equipe, como eu te coloquei... De a gente conseguir fazer essa orientação técnica para lá. Porque eu, na verdade, na coordenação da UTEES eu tenho uma agenda... Que tu não deve ter ideia né?

\section{P: Quer dizer, nesse momento é... É... É... É inviável... É... É... Uma formação lá...}

R1: Não. No momento assim... In loco é inviável. Acredito que na formação aqui, que a gente vai ter nessas USES, a gente possa estar... Como ele faz parte da USE $12 \ldots$ Se tiver essa jornada unificada de dois dias, com formação... Ele...

\section{P: Traz?}

R1: Trazer ele para cá para fazer a formação junto. $\mathrm{O}$ deslocamento dele e das outras professoras que estão lá... Né? Nos anexos também...

\section{P: Entendi.}

R1: Entendeu? É nessa... Mas assim In loco ainda não está a pensar sobre isso... Porque existe toda uma estrutura para fazer essa formação para lá. E a gente está como eu te falei... A unidade está em processo, está tramitando no conselho a regularização... E como a gente não tem essa regularização oficial junto ao Conselho Estadual de Educação logo a gente não tem uma verba. Tudo aqui nós fazemos com recursos de materiais que a gente vende... Por exemplo, teve agora a mostra de arte...

\section{P: Sim}

R1: Nós fizemos uns pufes né? Construído junto com os alunos, mas o primeiro dinheiro saiu do bolso do professor. O professor que comprou o material. Aí com a venda dos 11 pufes 
arrecadou para nós 600 e pouco, desses 600 e pouco nós retornamos o valor que o professor havia investido. E o resto ficou para a unidade para a manutenção de algumas situações... Que a gente precisa dessas atividades... Que a gente tem encontro de professores, encontro de gestores... Tudo isso demanda uma logística de café, água...

\section{P: Sim.}

R1: Essas questões todas. Então... A gente precisa de xerox... Então nós temos esse recurso, nessa situação. Aí nós estamos uma... Vamos ter umas oficinas. Nós vamos ter uma oficina e nessas oficinas com os alunos o quê eles também... O que eles construírem nós vamos tentar montar assim... Nós ainda não pensamos, mas estamos pensando em uma feirinha e nessa feirinha nós vamos captar algum recurso que a mãe vai estar fazendo também... Vamos ter as... Os encontros de família... Uma forma de geração de renda que a mãe pode estar para ela e pode estar revestindo um percentual para nossa... Para a nossa unidade. Para justamente atividade de confraternização dos alunos, dia das crianças... Essas coisa toda que a gente tem no nosso calendário. Esses... Essas datas comemorativas do calendário né? Que a gente... Que demanda um lanche, demanda uma série de coisa que se não tem recurso não tem como fazer né?

\section{P: E assim... E... Só para finalizar... Em relação à Marta. Principalmente a questão do ensino fundamental... Porque a... Eu sei que você não tem todas as informações, mas a tua visão em relação ao atendimento lá da escola... Agora que escola está retornando com as suas atividades...}

R1: Não. Realmente eu não consigo nesse momento te dar essa visão abrangente né? O que de imediato... Porque na verdade foi o diretor que me solicitou. Desde quando eu assumi ele disse que precisava da minha presença lá...

\section{P: Ótimo.}

R1: Então eu vim.. Por uma agenda eu vim arrastando esse momento até que a gente conseguiu marcar naquele dia. Então na verdade ele ficou de me repassar qual seria as grandes problemáticas, mas ele não chegou a me passar. Quando eu cheguei lá que eu fui realmente saber de fato o que eu tinha ido fazer. Ele só queria minha presença porque ele 
tinha mais situações para me colocar. Que mais situações nessa questão do quantitativo de alunos. Se estava certo... Aí na oportunidade aquela orientação técnica que eu te falei. Foi que eu dei também para o professor como ele organizar o trabalho dele. Porque o atendimento do AEE ele é feito individualmente ou pequenos grupos. Geralmente é feito individualmente então como ele é individual eu preciso pensar no plano individual para esse aluno. Então eu dei toda a orientação para ele nesse sentido. Da importância do que ele projetou para este aluno ele está dentro da pasta porque qualquer... Qualquer pessoa que chegar na escola... Porque esse documento ele não é do professor do AEE, ele pode ter o dele lá, mas ele é um documento... A pasta do aluno ele tem que estar na secretaria porque ele é aluno da escola. Ele não é... Ele... O professor atende ele, mas a documentação não tem que estar com ele. Tem que estar na secretaria da escola. É que antigamente era assim Macieira...

\section{P: Ou seja...}

R1: O documento do aluno da Educação Especial ele ficava com professor, no armário do professor. Depois desse processo mais avançado que a documentação desse aluno passou a ficar na secretaria e algum funcionário dando conta disso aí... Mas antigamente era o professor que tomava conta da... De todo documento do aluno dele. Entendeu? Era assim que era feito. E aí ele precisa estar com essa pasta porque a qualquer momento se a mãe chegar lá quer uma transferência ou quer saber da situação... Mas ali está completa a pasta do aluno. Foi essas orientações que nós demos para ele. É... Aqueles alunos que estão ausentes do atendimento... É saber por que que está ausente, procurar resgatar esse aluno para o atendimento... Porque eles, em si, esse aluno da Educação Especial eles são muito ausentes. Principalmente se depender da patologia, das condições... É... De saúde deles... Eles são muito ausente. Então se a gente não estiver ali estimulando a participação dele, a importância dele no atendimento... A gente... A maioria deles passa assim semanas sem aparecer. Uns têm uma justificativa realmente porque eles adoecem ou às vezes com facilidade... Dependendo da situação de saúde dele, mas outros realmente acabam evadindo. Então essa questão também de orientação... De saber por que que o aluno está faltando, entrar em contato com a família, estar sempre em parceria com a família... Ele... Foi a orientação que ele tem... Que tem que estar envolvido. Que tem algumas escolas que tende a fazer a programação deles separado dos outros. Coisas que já eram para ter sido superadas... Mas a gente está encontrando... Não estou dizendo que é no Marta, mas em algumas escolas a gente ainda encontra. Quero fazer a programação do meu aluno separada... Como se ele fosse algo à parte né? Então se é uma 
programação festiva do calendário escolar daquela unidade então o aluno tem que participar como qualquer outro aluno. Então a gente refez... Ele fez uma... Reafirmou essa importância de eles estarem participando... Então como o Marta... É... Quando eu assumi, o Marta estava realmente em greve. Não era nem greve... Primeiro foi a greve, depois foi a reforma né? Então nesse período praticamente o Marta não teve assim.. Não teve uma continuidade. Agora que realmente eles estão voltando para o trabalho. Então eu não posso ter ainda essa visão geral que tu estás querendo do Marta. Talvez em outra oportunidade...

(Risos)

\section{P: Então tá Irene. Obrigado!}

R1: Então essa é a Sandra que é a nossa coordenadora daqui também..

P: Oi Sandra. Tudo bem? Então vamos lá... É... Eu acho que... Até aproveitando para ti né... Eu ia te falar dessa questão da... Que não existe diretrizes operacionais da... Uma educação inclusiva no estado... Eu acho que tu poderias falar também dessa relação do aluno e professor... E a família né?

R4: Aham...

P: Principalmente o aluno com deficiência intelectual. Né? Que tu podes observar nessa tua experiência... Principalmente nessa área que tu atuas...

R4: Aham...

P: Aqui da região de Icoaraci e ilhas...

R4: Assim.. É... Assim... A gente é... É aquele... É aquela...

P: Primeiro o seu nome... Quanto tempo trabalha... 
R4: Sandra. Sandra Ferrari. É... Eu sou técnica aqui né? E também sou professora da Educação Especial. Atuo nas duas... Nessas duas diretrizes... E... Tenho 23 anos de Educação Especial né?

\section{P: Estais lotada aqui na...}

R4: Sou lotada aqui na UTEES. É... Sou das antigas... Temporária... Passei no concurso... Vim de toda... Nessa trajetória aí... Nesse processo de... Da educação inclusiva né? Sim... É... Assim.. Nós... É... A gente... Primeiro... Primeiro ponto é trazer essa familia né? Próximo da gente né? Trazer essa família. Mas aí sim... O que é que a gente percebe da família que tem uma criança com déficit intelectual... Né? Que é uma familia que ela já vem desacreditada em função dessa criança ter muito... Muitas questões de repetência né? De repetência na escola, de retenção né? E aí essa criança ela já vem... A gente já... Já... Quando a gente... Essa familia já chega com a gente... Ela já vem nesse processo. Né? De... É... Sentir a família... A criança se sente incapaz e a familia também. Né? E é todo um trabalho para desconstruir isso né? De mostrar para essa familia e para essa própria criança de que ela é capaz. Né? De que ela tem as potencialidades dela. Ela tem as dificuldades né?Mas ela tem a potencialidade né? E a gente trabalha na Educação Especial em cima desse potencial. Né? Em cima desse potencial. E isso a gente procura mostrar para essa família né? Que essa criança tem o potencial e que a gente tem que investir nela. Né? Que a gente não pode deixar achar que ela é incapaz, que ela não vai passar daquilo... Não. A gente trabalha em cima desse potencial né? E o nosso trabalho... Assim... É... É... É verificar realmente em quê que a gente pode... É... Investir nessa criança... Né? E nessa família...

P: $\mathbf{E}$ diante disso o quê que você tem notado em relação à escola? Se o aluno tem essa dificuldade, vem repetindo... Né? Que tipo de metodologia tem sido usada? Ou... Ou não tem? Não tem uma metodologia que garanta esse retorno para este familiar e para essa criança...

R4: É essa a questão. É esse... É esse trabalho com a escola também. De mostrar para essa escola... Para a escola que essa criança tem um potencial. Né? Porque a avaliação... O grande entrave é a avaliação. Né? A avaliação eles avaliam... Traçam-se objetivos. Né? E essa criança ela é avaliada dentro desses objetivos que o professor traça. E se a gente tenta trabalhar em cima disso... 


\section{P: Não existe uma avaliação diferenciada?}

R4: Diferenciada. E aí.. O quê que... Qual é o nosso trabalho né? Os profissionais da Educação Especial... Mostrar para esse professor que ele tem que trabalhar em cima do potencial desse aluno. Né? Não fazer uma avaliação pelo que o aluno... Vamos dizer... Pelo que o aluno... Pelas... É... Eu não digo incapacidade... Pelo que o aluno não pode te dar. Né? Qual é o retorno que esse aluno pode te dar? Vamos trabalhar em cima disso. Não em cima do que ele não pode te dar. Né? E aí a escola às vezes ela trabalha em cima disso... Por isso que há o fracasso do aluno né? E aí que vem a questão da... Da... Da... De a gente trabalhar e fazer as adaptações. Né? Que é o grande "X" na escola. As adaptações né? Do... De como vamos trabalhar determinados conteúdos para poder esse aluno atingir um determinado objetivo...

\section{P: Existe então uma... Uma resistência do diagnóstico de vocês para... Para o professor, para a escola... Você dá uma fórmula e nem sempre isso é seguido?}

R4: Isso. Essa é a grande discussão. Quando a gente... Quando, no caso, eles chamam a gente para... Que está havendo um impasse em uma escola... Né? Ah! O impasse que o aluno, o professor... É... Quer reprovar o aluno por isso, por isso e por isso... A gente vai. O professor argumenta. Né? Aí a gente sempre chega a essa conclusão... Que ele... Que o professor argumenta em cima do que o aluno não pode, das impossibilidades... Não em cima das possibilidades. Aí a gente começa a mostrar para o professor é... E aí professor o quê que o senhor acha? E aí a gente pede para ele falar um pouco, se ele conhece o aluno, fala... Aí o professor começa a falar... Tá vendo? Você está falando. Você está avaliando ele dentro do que... Dentro do que ele sabe, mas essa avaliação que você fez aí foi em cima do que ele não... Do que ele não vai consegui... E aí... É por isso que a avaliação... Ela é... A gente discute porque ela repete... Ela perpassa muito pela questão da flexibilização curricular.

\section{P: Que não há?}

R4: Que não há. O professor ele trabalha o conteúdo dele na íntegra. É aquele conteúdo. E ele traça aquele objetivo... Para todos. De... De maneira... Né? De... Igual. Aí quando ele vai avaliar ele avalia da mesma forma. Ele não vê que lá naquela... Lá na sala dele ele tem... Ele tem que planejar e ele tem que planejar para várias pessoas. Ele não tem que planejar em cima 
de... De... De... De um... Vamos dizer... É... Vamos dizer, ele vai... Vai colocar todos em um mesmo nível. Né? Ele não pode planejar vendo todos no mesmo nível. Ele tem que conhecer a turma dele, a realidade dele... Para ele poder fazer um planejamento. Né? Aí vamos ver na turma dele ele vai ter um aluno que... Que não vai acompanhar aquela turma, mas que tem capacidade... Que tem potencial. Então o quê que ele tem que fazer? Ele tem que fazer um planejamento de forma que ele vá atender aquele aluno também. Que tem seu potencial. Que não... Que não vai acompanhar da mesma forma que ele gostaria, mas que tem condições. Entendeu? E ele tem que ver dentro de um conteúdo o quê que ele pode... É... Cobrar daquele aluno. O que dá para aquele aluno dar de retorno para ele. Né? Porque o aluno vai dar um retorno. Não vai ser o retorno que ele quer. Né? Mas se ele for avaliar aquele aluno pelo que ele pode, pelo potencial dele, ele vai ter retorno daquele aluno... E é a grande situação... A discussão que nós temos na escola é essa. Toda vez que nós vamos na escola o maior impasse é esse. Quando a gente chega na escola é a questão da reprovação, às vezes, por essas questões... E às vezes o professor... Não é que ele... Que ele não... Que ele é... Tỉpo assim: ah ele fez isso porque ele... Ele não está nem aí para o aluno... Não é. Porque às vezes é por falta de conhecimento. É a questão da... Da formação, do estudo... Porque também a gente coloca muito para o professor... Ele tem que correr atrás. Ele tem que buscar. Né? A gente tem que estar em processo... De estudo constante. O professor não pode... Aí ele... Ah eu sou professor de... Vamos dizer... De matemática né? Então o meu conteúdo eu conheço, eu sei das minhas aulas, mas não é só isso... Né? Existe toda uma situação na minha sala que eu preciso ir buscar. Né? Se eu tenho uma situação diferenciada aqui eu tenho que buscar... É... Condições para trabalhar com essa situação diferenciada. Não é porque eu conheço o meu conteúdo, que eu já sei dar as minhas aulas, que eu já tenho todo... E aí é que vem a questão. E às vezes o professor não faz a coisa não é porque ele não quer. É por falta de conhecimento. Às vezes ele não quer se dispor a ir buscar, a ir estudar... Preciso, às vezes, estar ali... Sabe? E não... E a gente não tem... É... É... É... A nossa... Estrutura... Ela não dá condições para que a gente esteja realmente lá o tempo todo. Né? Você já verificou como é a situação né?

\section{P: Sim.}

R4: Então o professor, às vezes, ele tem que estar correndo atrás de conhecimentos, de informação... Porque se ele não fizer isso ele vai continuar ali... É... Discriminando esse menino... É... Fazendo assim.. É... A... Trabalhando no sentido que este menino para que a 
autoestima fique lá... E que o menino se sinta um fracassado... E que a família também se sinta fracassada...

\section{P: É uma formação em Direitos Humanos? Na área da Cidadania?}

R4: Justamente. E eu acho também que passa muito pela sensibilidade sabe? Ao professor ser sensível àquela situação né? Àquela situação daquela pessoa que está ali... Porque é um ser humano né? Então ele no momento que ele se sensibiliza ele vai buscar a forma de ajudar aquela pessoa. Né? De dar um encaminhamento para aquela pessoa... Né? Porque não basta o aluno está lá na sala. Tá... É o aluno. Está lá. Tá já... Está na escola, está lá... Mas não é só isso né? Eu tenho como professor garantir que esse aluno tenha qualidade. Né? Que não é só ele estar ali. Ele teve... Ele está... Foi, entrou na escola... É o acesso. Ele está lá. E a qualidade né? E a permanência dele com qualidade? Eu como professor eu tenho essa responsabilidade. Né? E é uma questão que a gente tem assim discutido muito...

\section{P: E você observa em vários...}

R4: Isso.

\section{P: Nessas... Nas escolas?}

R4: Nas escolas. A maioria... É como realmente a gente falou... É uma questão... É... Que a gente discute muito na... Na... Nas nossas discussões. E isso eu te falo que não é só a nível de estado, é a nível de prefeitura também. Porque eu também sou da prefeitura. Eu sou do CRI.

\section{P: Sim.}

R4: E a gente... Eu trabalho com a EJA. Pelo CRI. Eu faço assessoramento à noite aqui no distrito, nas escolas... E também a gente vê muito isso nas escolas. Principalmente com os professores de disciplinas. Os professores licenciados né? Português, Matemática, História, Geografia... Porque as séries iniciais do fundamental menor a gente não percebe tanto isso porque é um professor. Dá para ficar mais próximo... Mas os professores de disciplina, até pela questão da carga horária que eles têm... De correr de uma escola para outra... Eles 
acabam deixando meio a coisa... Sabe? Caminhar... Deixar de lado... E... E essa realidade ela é geral.

\section{P: E aí o aluno vai ficando de lado?}

R4: E vai ficando de lado. E aí vai tendo... É... Vai ficando... Né? A repetência... E ele vai ficando desestimulado né? E tem várias questões assim... Que é uma das questões que mais a gente... A gente... É... Indepara. Né? Que é essa questão mesmo da... Da... Desse trabalho que a gente sabe que é um trabalho que a gente tem que marcar em cima. Que a gente tem que... Né? Persistir mesmo né? Do professor estar se preparando, estar correndo atrás de conhecimento... Né? De formação mesmo né? E às vezes ele tem que fazer por ele. Não tem que esperar que... Que COES, que a Unidade... Né? Porque a gente trabalha dentro das nossas possibilidades, mas eu acho que se a gente está lá no espaço da sala de aula a gente tem que essa responsabilidade de correr atrás...

P: E vocês sentem aqui? Até vou falar com. Essa... Também existe uma... Uma deficiência na estrutura...

R4: Com certeza. Isso aí é... Essa... Essa deficiência toda que a gente... Que a gente tem... Isso dificulta para que a gente seja mais próximo. Que a gente faça um trabalho. Porque assim... Eu acho assim...

\section{P: Se houvessem mais recursos financeiros...}

R4: Mais recursos. Né? Mais estrutura... Até de... De pessoas também né? Olha aqui na unidade...

\section{P: Então falta não só recursos financeiros, mas de pessoal...}

R4: É. Por que... Olha, por exemplo, aqui na unidade nós trabalhamos... A Irene que está coordenando e eu sou a única técnica. A gente não está conseguindo técnico para vir para cá para dividir o trabalho... Para a gente poder articular melhor nas escolas...

\section{P: E vocês já solicitaram isso?}


R4: Já. Já foi solicitado, mas tem toda uma situação... Que não tem técnico para vir, que não tem... A gente precisa... A gente não tem uma equipe. A gente precisava de um Psicólogo, a gente precisava de um Assistente Social, a gente precisava de vários profissionais para montar uma equipe de trabalho...

\section{P: Isso vocês não têm?}

R4: Nós não temos. Só somos nós duas. Eu como técnica e ela como a coordenadora... E os professores que dão apoio... Porque eles são professores. Então que atendam os alunos. Eles acabam, em algum momento, fazendo o trabalho de técnico. Ajudando a gente nas... Nas atividades que a gente tinha que fazer externo. Formação... Né? Tudo eles dão apoio para a gente. Aí a gente acaba pedindo ajuda dos parceiros, dos amigos... É... São professores da UEPA que a gente conhece e que a gente pede... Não tem como pagar né? Vem em uma palestra com esse determinado tema para a gente? Vem desenvolver um trabalho assim como a gente? Vem? Assim...

P: E às vezes o próprio diagnóstico você precisa de uma inserção de um... Por exemplo, de um Assistente Social, de uma Psicóloga...

R4: Tudo. Dos profissionais... De um Fono... De um... De uma equipe. Por que...

\section{P: Fonoaudiólogo...}

R4: Justamente. Aqui nós não temos. É... O... Antes a gente trabalhava com avaliação agora já não está... Nós estamos encaminhando tudo lá para o COES porque nós não temos ninguém aqui... Não tem equipe.

\section{P: Terapeuta ocupacional...}

R4: Não temos. Nem... Nada...

P: Por exemplo... Se o aluno necessitar de um desses profissionais de apoio não tem? 
R4: Aqui nós não temos. Aqui em Icoaraci nós não temos. Tem que procurar... Mesmo assim... Em locais que tenham, nas unidades que tenham..

\section{P: Encaminhar para uma unidade de saúde?}

R4: Isso. É assim que estais a trabalhar... Aqui na UTEES nós não temos. Só... Somos só nós duas. Que somos pedagogas né? E os professores... Que são os professores de Educação Física e os Pedagogos que fazem o atendimento... Só mesmo. Aqui a gente não tem um Psicólogo, a gente não tem um Fisioterapeuta, a gente não tem o Assistente Social... A gente não tem...

\section{P: Que dê um suporte para o aluno...}

R4: Que dê suporte...

\section{P: Dentro da escola...}

R4: Não temos. Não temos... A dificuldade é muito grande aqui. Aqui a gente realmente trabalha com... Com as nossas possibilidades né? E como eu lhe falei: a gente sempre está buscando apoio das pessoas... De fora né? Quando a gente corre pra cá, corre para amigos, corre para pessoas que a gente conhece... E pede uma ajuda... Dá para ti dar um apoio aqui para a gente? Dá para... Sabe? É assim. Quando a gente tem formação aqui a gente precisa de profissionais... Assim... Para vim... Palestra... Tudo. É tudo assim. É... Solicita... A gente tem algumas...

\section{P: Quer dizer... Aquilo que está na lei e na política acaba não sendo observado no entanto...}

R4: Até então... E tem toda uma questão assim... A gente tem dificuldade de lidar... É a questão do sistema. Assim... Até o sistema de lotação da SEDUC. Que é muito fechado. É um sistema assim que ah... A realidade é essa, a gente precisa disso, mas lá no sistema diz que não. Por exemplo, essa situação de professor... É... Ah a gente precisa do professor aqui... Não, mas o sistema diz que não precisa porque não tem isso aqui... Aquilo suficiente para 
lotar esse professor aqui... Entendeu? Olha... É... É... Então a gente lida muito com essa questão mesmo de... De sistema... De...

\section{P: Burocrática...}

R4: A questão burocrática. Muito!

P: Assim... Por mais que dê um diagnóstico de que necessita de mais um professor de Educação Especial aqui... Um professor aqui...

R4: Porque assim... A lotação...

\section{P: É negada?}

R4: É. A lotação ela é feita pelo número de alunos. Só que a gente... É aquela situação... Nós temos, por exemplo, alunos que são muito comprometidos. Que eles precisam de vários atendimentos. E aí eles acabam, vamos dizer assim, ocupando a vaga de 2, 3 alunos... Que o professor... Tem que ter um tempo mais com aquele aluno, o professor tem que fazer um trabalho diferenciado... E aí é um tempo mais. Aí... Isso tudo assim... O sistema não... Não vê... Entendeu? Não vê, não... Isso aí não... Porque é uma questão bem prática mesmo. É uma questão de quem está ali, de quem está vendo, de quem presencia a situação. É tudo muito complicado. Lotação... É tudo isso assim... É bem... A gente... A gente quando começa viver isso, a gente começa... Né? É... Participar dessa situação aí a gente começa a ver que uma coisa é... Quem está lá fora não tem noção. Mas a gente começa a ver o quanto é difícil lidar com essas situações. Sabe? Que... Que acaba emperrando todo esse processo. Sabe? Emperram todo o nosso processo de trabalho. De dar... De... Vamos dizer assim: dar um... Uma... Uma arrancada maior para o trabalho. A gente lida com todas as situações.

\section{P: Ok... Você queria é encerrar com mais alguma coisa? Assim...}

R4: Não. Eu acredito assim que... É... O quê que a gente, por exemplo, aqui na UTEES né? É... É... É... O nosso trabalho aqui é... A gente trabalha com as familias né? Trabalha com os alunos... Agente procura fazer um trabalho não só... Né? Com esse aluno, mas com essa familia que precisa desse apoio, de orientação, de estar orientando, encaminhando... Tipo 
assim... Olha: você pode ir por aqui, você pode resolver dessa forma, você pode... E que eu acho que esse é a nossa função né? Tá encaminhando as coisas... Não... Num sentido geral da... Do... Da criança. A gente se preocupa com essa criança e com... Crianças e adultos. Porque nós trabalhamos com adultos aqui. A gente tem alunos de cinquenta anos, de quarenta e poucos anos... Com essa clientela... Com essa pessoa e com essa familia... Né? Aí... E é isso. É esse trabalho que a gente procura desenvolver e estar apoiando as escolas... Né? Dentro das nossas possibilidades né? Mas a gente procura estar dando este apoio geral...

P: Tá. Muito obrigado. É só terminar aqui de...

TEMPO TOTAL = 1h $15 \mathrm{~min} 11 \mathrm{seg}$ 


\section{ENTREVISTA}

\section{Data:}

Local: Escola Estadual Marta da Conceição - Cotijuba - Distrito de Icoaraci - Belém / PA

Entrevistados: Pais do aluno Israel

\begin{tabular}{l|l}
\hline SÍMBOLOS & LEGENDA \\
\hline $\mathbf{P}$ & Pergunta ou fala do entrevistador \\
\hline $\mathrm{R}$ & Resposta ou fala do entrevistado \\
\hline Itálico & Compreensão duvidosa \\
\hline (... 0min) & Trecho não compreensível \\
\hline$\ldots$ & Pausa na fala \\
\hline
\end{tabular}

R1: De ler, de escrever bem... Eu digo para ele que ele vai ser juiz. Aí ele diz: tá mãe, tá... É... Pois é... Porque ele vai ser. Ele diz: tá mãe, tá... Aí ele pega e faz essas atividades. Sai muito bom. Mas o que eu espero é que ele aprenda a escrever, ler... Que quando ele está de bom humor ele senta, aí lê, escreve...

\section{P: E na tua avaliação? Tu entendes que ele pode chegar? Que ele pode conseguir com os estímulos necessários?}

R2: Pode. Pode... Pode sim. Com certeza...

\section{P: Tu viste...}

R2: A gente precisa... É que (0min 37seg). Só que a gente precisa focar nisso né? Então tem que ser um trabalho em conjunto. Que tem que envolver a escola, a família... Atendimento médico não é? Para ele... Assim... E a gente direcionar isso. Pode sim. Tudo é possível. E eu queria que o senhor entrevistasse mesmo... 


\section{ENTREVISTA SEMI-ESTRUTURADA POR EMAIL A PROFESSORA SCHEILLA CASTRO ABBUD VIEIRA EM JUNHO DE 2016 :}

1- Se identifique.

- Nome: SCHEILLA DE CASTRO ABBUD VIEIRA

- Profissão: Professora, Especialista em Metodologia do Ensino da Educação Especial (UEPA), Mestre em Ciências da Educação (UFPA)

- Função que ocupou: Professora em Unidade Educacional Especializada a alunos com DI, Professora em Sala de Recursos Multifuncional, Gestora na Região Norte da Ação TECNEP/SETEC/MEC (Ação de atenção a PcD na Rede Federal de Educação Profissional e Tecnológica)

- Função que ocupa atualmente: Professora em Unidade Educacional Especializada a alunos com deficiência visual/DMU e Professora na UEPA

- Tempo de experiência na área de atendimento a alunos com deficiência intelectual (DI): 12 anos.

2- Como compreende o processo de inclusão educacional de alunos com DI atualmente, e quais os avanços e percalços neste processo que observou no seu período de atuação e estudo na área.

- Compreendo como um processo em desenvolvimento em que, de um lado temos políticas mal formuladas que tentam atender às exigências legais e de outro lado alguns profissionais e familiares que tentam se ajustar a essa situação. Apesar do estabelecimento de diretrizes e normas que visam o processo de inclusão, o que percebo é que, em termos educacionais, os sistemas ainda pensam a inclusão do ponto de vista integracionista e isso é perceptível na discrepância que se encontra entre o número de matrículas efetivadas e o número de alunos que avançam em anos/séries (retenção) ou que avançam sem que tenham desenvolvido as habilidades mínimas exigidas nas normativas vigentes.

Em termos de avanços percebo que, apesar da forma como vem se dando esse processo, a permanência de alunos com DI nas escolas regulares tem possibilitado a esses sujeitos o desenvolvimento de habilidades sociais e cognitivas pela convivência com outros sujeitos sem DI, e que lhes servem de modelos comportamentais por possibilitar outras trocas, outras regras sociais, atitudinais e cognitivas e, de acordo com teóricos sociocognitivistas, os pares com mais habilidades funcionam como mediadores no processo de construção do conhecimento. Percebo também que um número maior de profissionais tem buscado formação a respeito das questões educacionais e legais.

Como percalços, percebo que a falta de estruturação de ações efetivas em nível macro (secretarias de educação) e micro (escolas) tornaram o processo de inclusão mais lento e de difícil compreensão. A desmobilização das classes especiais, ocorrida ainda no final da década de 1990, embora tenha buscado uma organização que garantisse aos alunos com deficiência intelectual, à época jovens/adultos, respostas educativas adequadas, não alcançou os objetivos pretendidos e esses sujeitos, em sua maioria, restaram nas escolas sem avanços acadêmicos que lhes garantisse ingresso em níveis mais elevados de ensino ou mesmo qualificação profissional.

Quais as principais ações pedagógicas e políticas que entende pra o atendimento educacional de qualidade do aluno com DI.

- As ações pedagógicas devem ser direcionadas para o desenvolvimento das mesmas competências pensadas para os demais sujeitos, sem desconsiderar que há questões 
que devem nortear essas ações. Partir das habilidades que o aluno já manifesta, é fundamental. Para isso é necessário que professores e demais profissionais da escola conheçam o aluno e a respeito da deficiência intelectual. Esse é o primeiro movimento para estruturar qualquer ação pedagógica. A identificação das necessidades específicas, relativas ao sujeito e às consequências da deficiência devem definir estratégias, técnicas e recursos adequados para o processo de ensino e aprendizagem. $\mathrm{Se}$ os procedimentos avaliativos forem pensados em suas modalidades diagnóstica, formativa somativa é possível dimensionar os aspectos envolvidos nas práticas pedagógicas e proceder os ajustes necessários para o atendimento de qualidade. Da mesma forma as politicas educacionais devem ser pensadas considerando as mesmas questões: para quem são destinadas? O que se pretende alcançar? Que consequências pedagógicas, sociais e estruturais as politicas perseguem? A falta de conexão entre o que é definido nas políticas e o que concretiza tem demonstrado que uma das ações necessárias é a articulação intersetorial. Muitas vezes o aluno com deficiência intelectual necessita de profissionais de outros sistemas, de modo a minimizar dificuldades que se manifestam como secundarias à deficiência, a exemplo das questões de linguagem, de uso de medicamentos, de fisioterapia, de laudos clínicos que possibilitem, a partir da identificação de possíveis comorbidades, um redirecionamento de ações educacionais e mesmo medicamentosas e ainda de questões relativas a assistência social.

3- Qual sua opinião sobre este processo de inclusão educacional de alunos com DI nas escolas de ensino fundamental junto à Secretaria Estadual de Educação (SEDUC), e principalmente das escolas situadas no Município de Belém de responsabilidade do Estado do Pará? Que problemas orçamentários, estruturais e de pessoal observa que dificulta o atendimento desses alunos junto a SEDUC. E que pontos positivos observa dessa estrutura.

- O processo ainda é de garantia de matrícula e de procedimentos de não retenção nas séries/anos em que a retenção não pode se dar. Observo que os casos em que a deficiência se manifesta em grau leve são os que apresentam avanços. Mas noto que esses avanços são ainda muito aquém do necessário e arrisco mesmo a localizá-los mais nos esforços da família que detém mais informações acerca de seus direitos (e que por conseguinte, busca outros atendimentos para além do educacional), do que nos esforções dos profissionais da educação.

- As questões orçamentárias são percebidas no geral da educação estadual e não apenas no que tange ao sujeito com deficiência. O reflexo disso para esse grupo especificamente, se manifesta nos cortes de recursos específicos para a atenção especializada; nas formações continuadas que não ocorrem com a frequência e qualidade necessária; na ausência de recursos didáticos nas escolas e mesmo na falta de salas de aula/escolas em quantidade suficiente, que garantam o disposto nos documentos que definem diretrizes para a organização das turmas em que estes alunos estejam inseridos e que determinam redução do número de alunos. Da mesma forma, apesar das normativas internas da SEDUC determinarem, em concordância com a legislação nacional, que os professores que atuam junto ao aluno com deficiência devem ter formação específica para tal, o que se observa é que as formações não tem a qualidade necessária que garanta a qualificação exigida a maioria desses profissionais.

- Observo também que a maior parte das escolas ainda não consegue definir em seus projetos políticos pedagógicos a estruturação necessária para a atenção ao aluno com DI: não há, nas chamadas semanas de planejamento, discussões sobre a organização de formações ou estudos sobre o tema. Também não são planejados os procedimentos de avaliação para identificação das necessidades específicas decorrentes da DI ou 
mesmo para elaboração de estratégias metodológicas para a garantia de respostas educativas adequadas.

- Os pontos positivos que consigo perceber são relativos aos esforços de profissionais que atuam no AEE e que tem buscado aproximação com os demais profissionais da escola, embora essa aproximação ainda se manifeste incipiente e unilateral. Percebo também que a SEDUC tem buscado organizar os procedimentos dos sistemas de matrícula, de modo a quantificar esses alunos (como os demais alunos que são público alvo da educação especial) e consequentemente quantificar o número de profissionais e habilitações necessários. Embora essa questão seja relativa mais a questão orçamentária do que a questão pedagógica em si, resultará em maior organização do sistema.

4- Se tens conhecimento ou fonte de dados quantos alunos atualmente com DI estão matriculados no ensino fundamental, principalmente entre o 10. ao 4o. ano?

- Esse número pode ser obtido nos dados do censo educacional, mas são relativos ao ano de 2015, pois embora o ano letivo de 2016 tenha iniciado em abril e as matrículas dos alunos com deficiência anteceda a dos demais, as mesmas ainda não encerraram. É importante referir um dado preocupante e que remete a questão anteriormente citada sobre a falta de salas de aula/escola em quantidade suficiente: muitos gestores não informam alunos com deficiência por não ter como atender à exigência de redução de número de alunos nas turmas em que alunos com deficiência intelectual, autismo e deficiências múltiplas estejam matriculados. Some-se a isso o fato de que muitos pais, por desconhecimento dos direitos de seus filhos, têm medo da negativa de matrícula caso informem a deficiência de seus filhos.

5- Quais os principais problemas que ainda dificultam um atendimento satisfatório do aluno com DI nas escolas estaduais atuais? Como vê a atuação dos professores juntos a esses alunos? Se existe regularidade e qualidade nos processos de capacitação desses docentes. Os problemas foram anteriormente citados e passam, evidentemente pela questão da formação profissional que não atende às necessidades específicas da deficiência intelectual. No entanto, afirmo que essa dificuldade não é restrita apenas a esses alunos, pois os dados do Observatório Nacional do PNE 2014/Dados INEP informam que nos anos iniciais do ensino fundamental a taxa de reprovação foi de $7,3 \%$ e a distorção idade/série foi de 14,1\%; nos anos finais a taxa de reprovação foi de $15,2 \%$ e de distorção idade/serie de $27,3 \%$. No ensino médio a taxa de reprovação foi de $19,7 \%$ e de distorção idade/série foi de $28,2 \%$.

$\mathrm{O}$ percentual de crianças no $3^{\circ}$ ano fundamental que não atingiram o nível de proficiência/ANA (avaliação nacional de alfabetização) foi de 22,2\% em leitura; $34,5 \%$ em escrita e $57,1 \%$ em matemática. Com exceção da ANA, nos demais dados não foram quantificados os alunos com deficiência.

- Percebo a atuação da maioria dos professores junto a alunos com DI como de ausência de respeito aos direitos do mesmo, pela alegação de não saber como proceder pedagogicamente ou por não receber gratificação para tal atuação. Percebo também a confirmação da chamada profecia realizada: a descrença na capacidade desse aluno em construir conhecimentos leva o professor ao não investimento nas possibilidades de desenvolvimento dessas capacidades. Portanto, não importa a oferta de formações ou informações, pois o prognóstico já está previamente definido por esse profissional. Soma-se a isso uma crença muito forte em muitos profissionais de que esse aluno é responsabilidade dos profissionais que atuam no AEE.

- Sobre as formações, na rede estadual há uma frequência muito baixa de ofertas especificamente sobre a deficiência intelectual. 
6- Como se dá o atendimento na sala de aula e no contraturno em educação especial a esses alunos com DI, principalmente na escolas estaduais em Belém.

- O AEE ocorre, em sala de aula, pelo serviço de professores itinerantes que devem atuar junto ao aluno especificamente no sentido de auxiliar no desenvolvimento das atividades pedagógicas e junto ao professor no sentido de orientações quanto a procedimentos metodológicos adequados(inclusive avaliação) e uso de recursos específicos. No contraturno, o AEE ocorre em SRM, por meio de profissionais especializados. Entretanto, como afirmado anteriormente, a formação desses profissionais ainda está quem do necessário e a atuação configura-se, em sua maioria, como atividade não adequadamente planejada.

7- Se conhece a realidade da Escola estadual Marta da Conceição situada na ilha de Cotijuba em Belém-Pará.

- Não tenho informações suficientes.

8- Se as normas estaduais, currículos e planejamento pedagógico no Pará acompanham a política nacional do MEC nesta área de inclusão de alunos DI.

- As normas acompanham ou tem buscado se ajustar à política nacional, entretanto, os currículos escolares e os planejamentos pedagógicos, em sua maioria, ainda não se materializam adequadamente.

8- Suas observações finais sobre este atendimento especializado e perspectivas para seu avanço.

- O AEE implica em reestruturação dos procedimentos pedagógicos em todo o sistema educacional e não apenas nas escolas. Compreendo que o AEE deve se efetivar para além das Salas de Recursos Multifuncionais ou Instituições Especializadas. Deve, antes, ser de compreensão e de responsabilidade de todos os agentes educacionais. Enquanto a agencia maior (Seduc) não tiver o entendimento de que o administrativo deve atender ao pedagógico e não o contrário, a legislação não será suficiente para o desenvolvimento de normativas internas adequadas para a garantia do que está estabelecido nas diretrizes nacionais.

Assim, considero que é necessário o estabelecimento de fóruns permanentes de debates com e sobre os alunos com deficiência intelectual, em movimento de autoadvocacia. Considero também necessário a formação de redes intersetoriais que organizem realmente a oferta de serviços adequados e completares aos serviços educacionais. Isso implica o envolvimento das instituições de ensino superior para o desenvolvimento de pesquisas sobre a deficiência intelectual e a busca de alternativas pedagógicas, bem como a oferta de ações em nível de extensão e formação continuada.

Vejo como imprescindível a quantificação adequada desses sujeitos para a real visualização das necessidades de profissionais das mais diversas áreas de atuação, para a ampliação do número de salas de aula e adequada distribuição desses alunos pelas turmas; para a formação continuada de todos os profissionais envolvidos na escola e dos familiares desses alunos.

Percebo também que a presença dos alunos com deficiência intelectual nas escolas regulares provoca a inquietação necessária para a mudança procedimental, por afrontar o profissional da educação em sua capacidade e habilidade.

E ainda, percebo a necessidade de estratégias que mobilizem as famílias nessa atuação, como parceiros educacionais. 
